\title{
Statistical release
}

P0309.3

\section{Mortality and causes of death in South Africa, 2009: Findings from death notification}

Embargoed until:

30 November 2011

$11: 30$

Enquiries:

User Information Services (012) 3108600

\begin{tabular}{l|c} 
Forthcoming issue: & Expected release date \\
\hline 2010 & November 2012
\end{tabular}


Mortality and causes of death in South Africa, 2009: Findings from death notification

Published by Statistics South Africa, Private Bag X44, Pretoria 0001

(c) Statistics South Africa, 2011

Users may apply or process this data, provided Statistics South Africa (Stats SA) is acknowledged as the original source of the data; that it is specified that the application and/or analysis is the result of the user's independent processing of the data; and that neither the basic data nor any reprocessed version or application thereof may be sold or offered for sale in any form whatsoever without prior permission from Stats SA.

Stats SA publishes approximately 300 different statistical releases each year. It is not economically viable to produce them in more than one of South Africa's eleven official languages. Since the releases are used extensively, not only locally but also internationally, Stats SA releases are published in English only.

This publication is available on the Internet at www.statssa.gov.za.

\section{Stats SA products}

A complete set of Stats SA publications is available at the Stats SA Library and the following libraries:

- National Library of South Africa, Pretoria Division

- National Library of South Africa, Cape Town Division

- Natal Society Library, Pietermaritzburg

- Library of Parliament, Cape Town

- Bloemfontein Public Library

- Johannesburg Public Library

- Eastern Cape Library Services, King William's Town

- Central Regional Library, Polokwane

- Central Reference Library, Nelspruit

- Central Reference Collection, Kimberley

- Central Reference Library, Mafikeng

Stats SA also provides a subscription service.

\section{Enquiries:}

\section{Printing and distribution}

Tel: $\quad$ (012) 3108251

Fax: (012) 3217381

Email: distribution@statssa.gov.za
User information services

(012) 3108600

(012) $3108500 / 8495$

info@statssa.gov.za 


\section{Preface}

This statistical release presents information on mortality and causes of death in South Africa for deaths that occurred in 2009, as well as on deaths collected through the civil registration system in South Africa, maintained by the Department information on death occurrences from 1997 to 2008 to show trends in mortality and causes of death. It is based on data of Home Affairs.

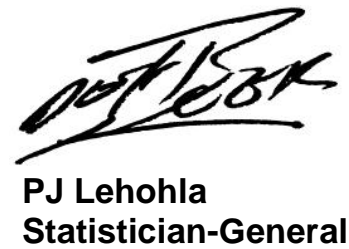




\section{Contents}

Preface .2

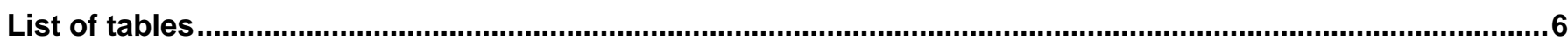

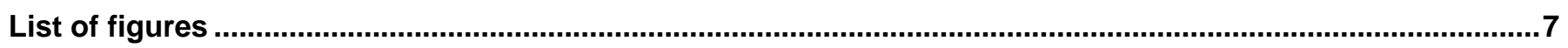

1. Introduction

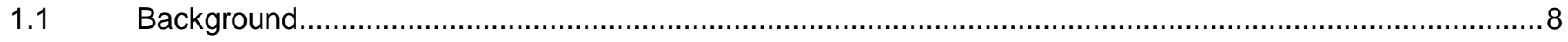

$1.2 \quad$ Objectives of this statistical release

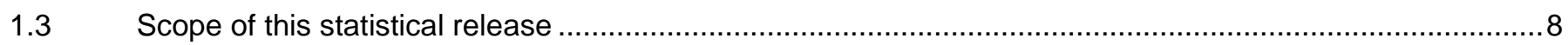

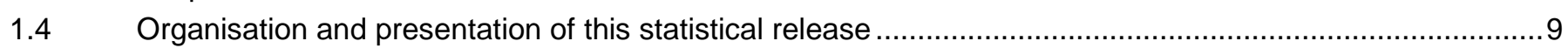

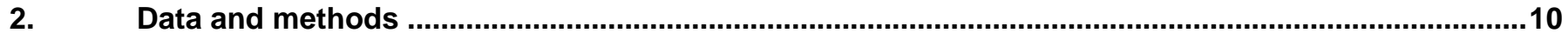

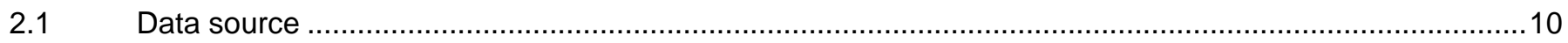

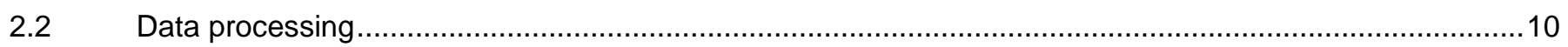

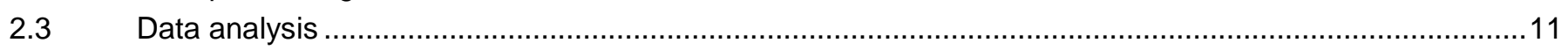

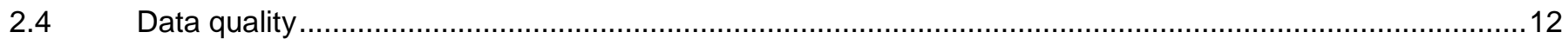

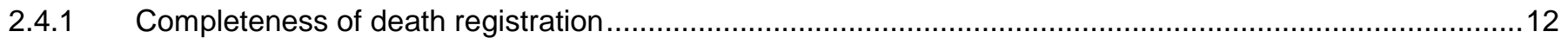

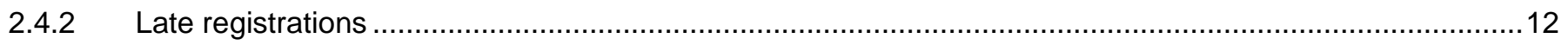

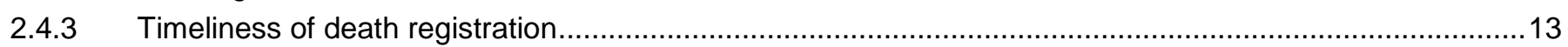

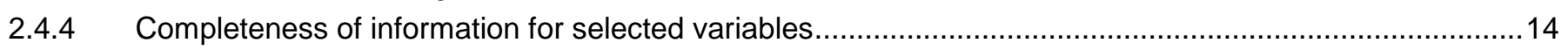

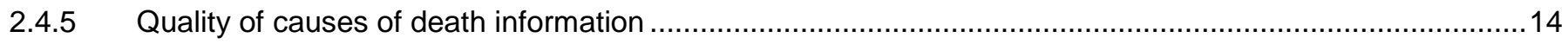

2.4.6 Assessment framework for death registration data ........................................................................ 15

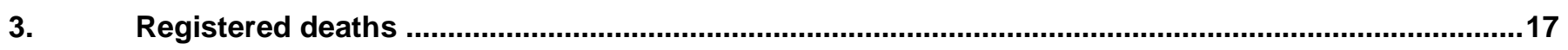

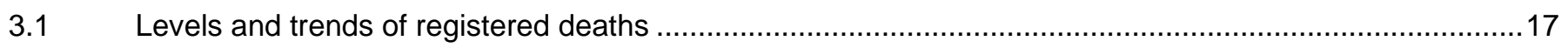

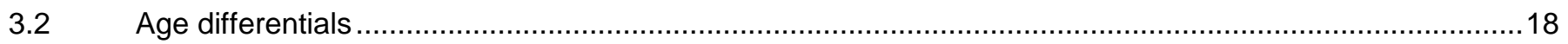

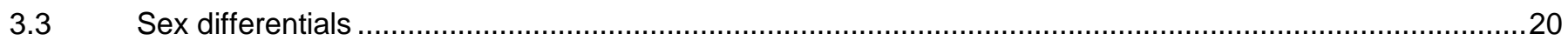

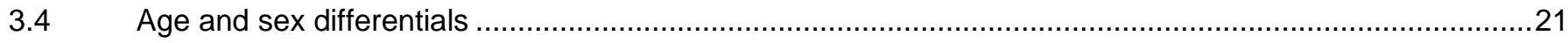

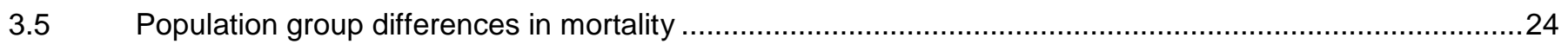

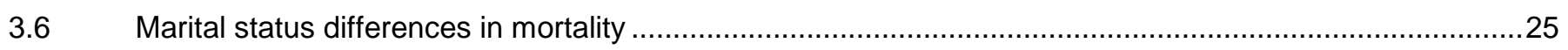

3.7 Differences in mortality by place or institution of death occurrence ......................................................25

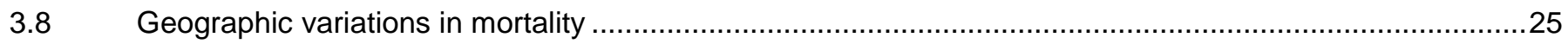

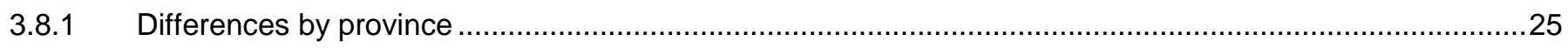

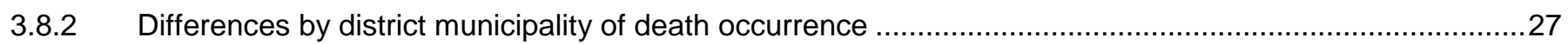

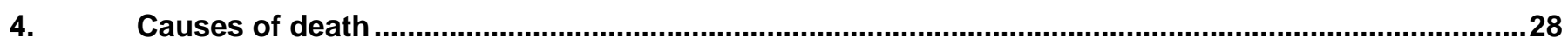

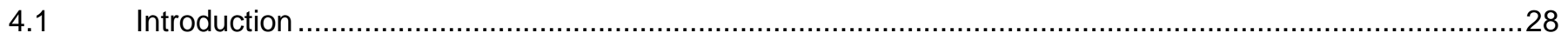

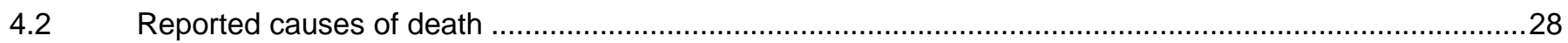

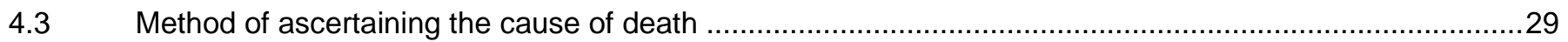

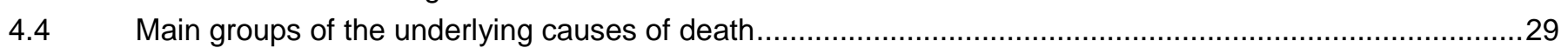

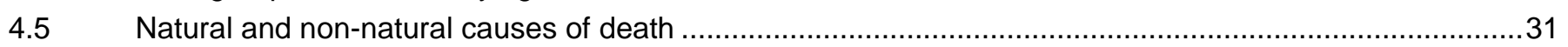

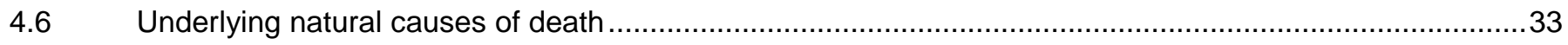

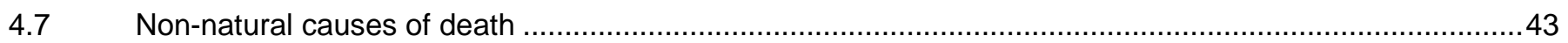

4.8 Comparison between immediate, contributing and underlying causes of death ........................................48

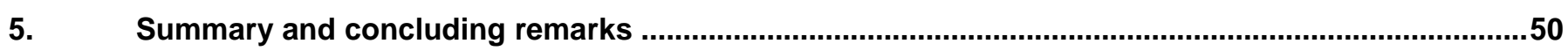


Appendix C.1: Number of deaths by age, sex and year of death, 2000-2002 ................................................57

Appendix C.2: Number of deaths by age, sex and year of death, 2003-2005 ..............................................58

Appendix C.3: Number of deaths by age, sex and year of death, 2006-2008 ..............................................59

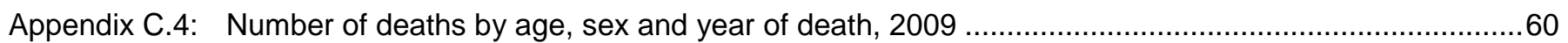

Appendix D: $\quad$ Year-to-year annual percentage changes in number of deaths by sex, 1997-2009 .....................61

Appendix E: $\quad$ Age specific death rates (ASDR) by year of death, 2005-2009 ................................................62

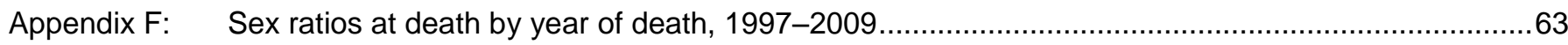

Appendix G: Number of deaths by province of death occurrence and province of usual residence of the deceased, 2009

Appendix G.1: Percentage distribution of deaths by province of death occurrence and province of usual residence of the deceased, 2009

Appendix $\mathrm{H}$ : $\quad$ Number of deaths by age, province and district municipality of death occurrence, $2009 \ldots \ldots \ldots \ldots \ldots . .65$

Appendix I: $\quad$ Number of deaths by sex, province and district municipality of death occurrence, 2009 ................67

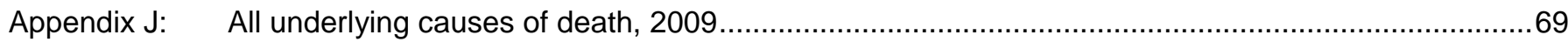

Appendix K: Detailed description of the broad groups of natural causes of death which were among the

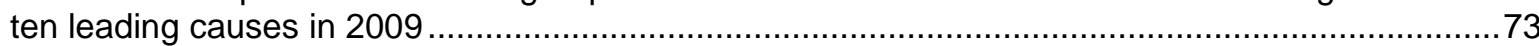

Appendix L: $\quad$ The ten leading underlying natural causes of death by age and sex: South Africa, 2009 ...............76

Appendix L.1: The ten leading underlying natural causes of death by age and sex: Western Cape, 2009 ............77

Appendix L.2: The ten leading underlying natural causes of death by age and sex: Eastern Cape, 2009 .............78

Appendix L.3: The ten leading underlying natural causes of death by age and sex: Northern Cape, 2009 ............79

Appendix L.4: The ten leading underlying natural causes of death by age and sex: Free State, 2009 .................80

Appendix L.5: The ten leading underlying natural causes of death by age and sex: KwaZulu-Natal, 2009 ...........81

Appendix L.6: The ten leading underlying natural causes of death by age and sex: North West, 2009 ................82

Appendix L.7: The ten leading underlying natural causes of death by age and sex: Gauteng, 2009 ....................83

Appendix L.8: The ten leading underlying natural causes of death by age and sex: Mpumalanga, 2009 ..............84

Appendix L.9: The ten leading underlying natural causes of death by age and sex: Limpopo, 2009 ....................85

Appendix M: Number of deaths by main groups of causes of death and district municipality of death occurrence (Western Cape, Eastern Cape and Northern Cape), 2009 ............................................86

Appendix M.1: Number of deaths by main groups of causes of death and district municipality of death occurrence (Free State, KwaZulu-Natal and North West), 2009.

Appendix M.2: Number of deaths by main groups of causes of death and district municipality of death occurrence (Gauteng, Mpumalanga and Limpopo), 2009.

Appendix $\mathrm{N}$ : The ten leading underlying natural causes of death by district municipality of death occurrence, Western Cape, 2009.

Appendix N.1: The ten leading underlying natural causes of death by district municipality of death occurrence, Eastern Cape, 2009.

Appendix N.1: The ten leading underlying natural causes of death by district municipality of death occurrence, Eastern Cape, 2009 (concluded)

Appendix N.2: The ten leading underlying natural causes of death by district municipality of death occurrence, Northern Cape, 2009

Appendix N.3: The ten leading underlying natural causes of death by district municipality of death occurrence, Free State, 2009

Appendix N.4: The ten leading underlying natural causes of death by district municipality of death occurrence, KwaZulu-Natal, 2009

Appendix N.4: The ten leading underlying natural causes of death by district municipality of death occurrence, KwaZulu-Natal, 2009 (concluded)

Appendix N.5: The ten leading underlying natural causes of death by district municipality of death occurrence, North West, 2009. 
Appendix N.6: The ten leading underlying natural causes of death by district municipality of death occurrence, Gauteng, 2009

Appendix N.7: The ten leading underlying natural causes of death by district municipality of death occurrence, Mpumalanga, 2009

Appendix N.8: The ten leading underlying natural causes of death by district municipality of death occurrence, Limpopo, 2009

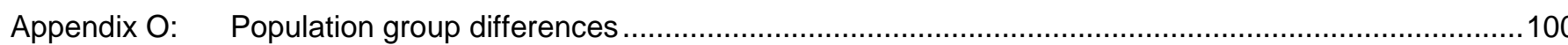

Appendix 0.1: The ten leading underlying natural causes of death by population group, 2009 101 


\section{List of tables}

Table 2.1: Number of deaths published in November 2010 and late registrations processed during the 2010/11 processing phase by year of death, 1997-2008 .

Table 2.2: $\quad$ Distribution of deaths by the number of days it takes to register a death, $2009 \ldots \ldots \ldots \ldots \ldots \ldots \ldots \ldots \ldots . . .13$

Table 2.3: $\quad$ Percentage of deaths classified as unknown/unspecified for selected variables, 2009.................14

Table 2.4: $\quad$ Percentage of deaths classified to symptoms, signs and abnormal clinical and laboratory findings not elsewhere classified, 1997-2009.

Table 2.5: $\quad$ Assessment of the 2009 South African death statistics from civil registration system using the framework proposed by Mahapatra et al. (2007)

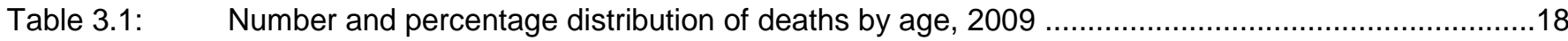

Table 3.2: $\quad$ Number and percentage distribution of deaths by population group, 2009................................24

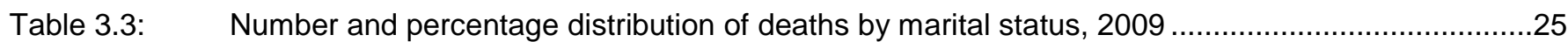

Table 3.4: $\quad$ Number and percentage distribution of deaths by place of death occurrence, 2009 .....................25

Table 3.5: $\quad$ Distribution of deaths by province of death occurrence and province of usual residence of

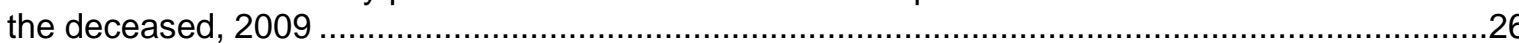

Table 4.1: Distribution of death notification forms by the number of causes entered on the form, 2009 .........28

Table 4.2: $\quad$ Number and percentage distribution of deaths by method used to ascertain the cause of death, 2009

Table 4.3: $\quad$ Number of natural and non-natural deaths by year of death, 1997-2009...................................31

Table 4.4: $\quad$ The ten leading underlying natural causes of death, 2007-2009...............................................34

Table 4.5: $\quad$ The ten leading underlying natural causes of death for males and females, 2009 ........................35

Table 4.6: $\quad$ The ten leading underlying natural causes of death for broad age groups, 2009 ........................38

Table 4.7: $\quad$ The ten leading underlying natural causes of death for infants and children, 2009 ......................39

Table 4.8: The ten leading underlying natural causes of death for the population aged 15-24 years, 2009.

Table 4.9: The ten leading underlying natural causes of death in each province of death occurrence, 2009

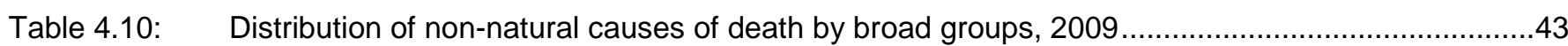

Table 4.11: Distribution of deaths due to other external causes of accidental injury, 2009 ............................44

Table 4.12: Underlying non-natural causes of death by age group and sex, 2009.....................................45

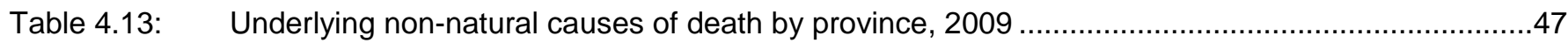

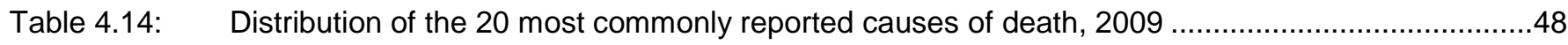

Table 4.15: Number and percentage of deaths selected as underlying or reported as immediate or contributing causes of death: 2009 . 


\section{List of figures}

Figure 3.1: $\quad$ Number of registered deaths by source of data and year of death, 1997-2009 _.........................17

Figure 3.2: $\quad$ Percentage distribution of deaths by age and year of death, 2005-2009................................19

Figure 3.3: $\quad$ Percentage distribution of deaths by sex and year of death, 1997-2009 .................................20

Figure 3.4: Crude Death Rates (CDR) by year of death and sex (adjusted number of deaths), 2005-

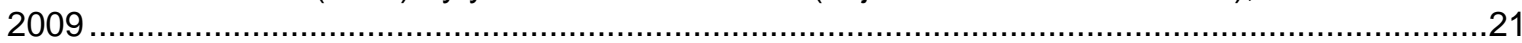

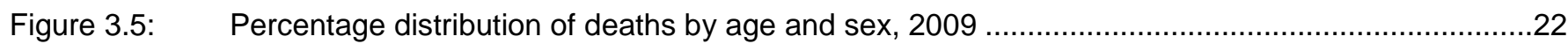

Figure 3.6: Median ages at death by sex and year of death, 1997-2009 .................................................23

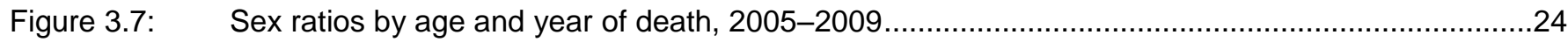

Figure 4.1: Percentage distribution of deaths by main groups of causes of death, 2009.............................30

Figure 4.2: $\quad$ Percentage distribution of deaths by selected main groups of causes of death and year of

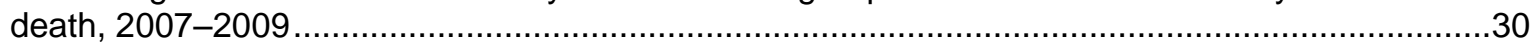

Figure 4.3: Percentage distribution of natural and non-natural causes of death by year of death, 1997-

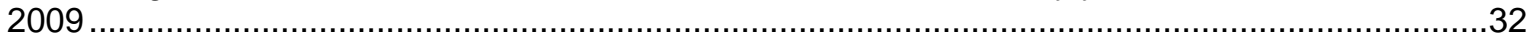

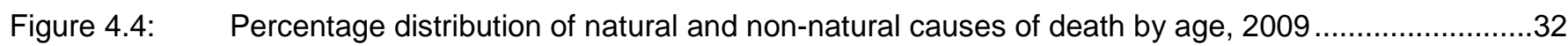

Figure 4.5: Distribution of deaths for the leading causes of death by year of death and sex, 2007-2009........36 


\section{Introduction}

\section{$1.1 \quad$ Background}

Statistics South Africa (Stats SA), in close collaboration with the National Department of Home Affairs (DHA) and the National Department of Health (DOH), annually produces statistical releases and data sets on mortality and causes of death based on information on deaths from the civil registration system in South Africa.

The registration of deaths in South Africa is governed by the Births and Deaths Registration Act, 1992 (Act No. 51 of 1992), as amended. The Act states that "in the case of a death due to natural causes, any person who was present at the time of death, or who became aware thereof, or who has charge of the burial concerned, shall give, as soon as practicable, notice of death" (Republic of South Africa, 1992).

If there is any doubt whether the death was due to natural causes, such a death must be reported to a police officer. After an investigation as to the circumstances of a death due to other than natural causes, the medical practitioner concerned shall, as soon as he is satisfied that the corpse concerned is no longer required for the purposes of an examination, issue a prescribed certificate to that effect. After death registration is completed, a death certificate is issued to the informant. All death notification forms are then collected by Stats SA for data processing and publication of statistical releases and data sets on mortality and causes of death.

The statistics on mortality and causes of death produced are an important source of demographic, geographic, and cause-of-death information. These statistics provide a valuable measure for assessing the health status of a population and in formulating health plans and policies to prevent or reduce premature mortality and improve quality of life. The level of mortality is one of the indicators of the well-being and health status of a population, hence its inclusion, among others, in the construction of human development indices, the Millennium Development Goals (MDGs), and in the multi-dimensional approach to the measurement of poverty.

\subsection{Objectives of this statistical release}

This release is part of a regular series by Stats SA on mortality and causes of death in South Africa, based on data collected through the civil registration system. It has three main aims:

- To provide contextual information on the data and methods used in order to support further specialist analysis of the data available from death notification forms. Data quality issues are also highlighted;

- To outline trends in mortality from 1997 to 2009 and differentials of mortality by selected demographic, social and geographic characteristics for deaths that occurred in 2009; and

- To present statistics on the causes of death for deaths that occurred in 2009 , focusing on the underlying causes of death.

\subsection{Scope of this statistical release}

This release is based on information on mortality and causes of death from the civil registration system. It covers all death notification forms that had reached Stats SA during the 2010/11 processing phase, focusing on deaths that occurred in 2009. Statistics for deaths that occurred between 1997 and 2008 are also provided (including late registrations processed in 2010/11) to show trends in mortality and causes of death.

The number of deaths discussed in this release excludes stillbirths, which are also collected through the civil registration system using the same death notification form. The definitions of technical terms used are provided in Appendix A. 


\subsection{Organisation and presentation of this statistical release}

The remainder of this release is organised as follows:

Section 2 describes the data sources, data processing and methods used to provide the results in this release. Issues related to data quality, including completeness of the processed information, late registrations, timeliness of death registration and reporting of causes of death information are also discussed in this section.

The overall levels, patterns, and trends of mortality are reported in Section 3. Specific emphasis is placed on age and sex of the deceased. The distributions of deaths by population group, marital status, place or institution of death occurrence, province of death occurrence and province of residence of the deceased are also provided in this section.

Section 4 provides information on the underlying causes of death. The analysis distinguishes between natural and non-natural causes of death and then focuses on the leading underlying causes of death in each category. Information on multiple causes of death is also included.

Summary and concluding remarks are presented in Section 5. 


\section{Data and methods}

This section provides information on data sources; data processing methodology pertaining specifically to causes of death; data analysis; and an assessment of the quality of data on mortality and causes of death.

\subsection{Data source}

Death registration takes place at the Department of Home Affairs (DHA). After a death is registered, the DHA issues a death certificate to an informant who registered the death and where applicable, updates the national population register (NPR). The NPR is updated only for South African citizens and permanent residents whose births were already registered on the NPR at the time of death. The details of the deceased who were non-South African citizens but who had sojourned temporarily in the country and all South African citizens and permanent residents who died before notice of their births had been registered are not captured in the NPR.

All death notification forms, including forms for deaths captured on the NPR as well as those not eligible for inclusion in the NPR, are then collected by Statistics South Africa (Stats SA) for data processing, analysis and dissemination of information on mortality and causes of death. While the NPR includes only South African citizens and permanent residents whose births were registered, Stats SA processes all death notification forms regardless of civil status. Consequently, the number of deaths processed by Stats SA will always be higher than the number of deaths recorded on the NPR for the same period.

This release is based on information recorded on death notification forms received from DHA for deaths that occurred in 2009 and were registered at DHA, including late registrations for the period 1997-2008. The data reported in this release are based on Form BI-1663 (Notification / Register of Deaths / Stillbirth) which was introduced in South Africa in 1998 (see Appendix B). Where the occurrence of death could not be certified by a medical practitioner, Form BI-1680 (Death Report) is completed by a chief/headman/induna to certify the death and to provide a description of circumstances that led to and caused the death. Form $\mathrm{BI}-1663$ has recently been revised and renamed DHA-1663.

During the 2010/11 processing phase, Stats SA processed a total of 572673 deaths that occurred in 2009 and 5044 late registrations for deaths that occurred between 1997 and 2008 (excluding duplicate registrations). The figure for 2009 deaths processed by Stats SA is $7,6 \%$ higher than the number of 2009 deaths recorded on the NPR (532 713) by 20 July 2011. The number of deaths processed by Stats SA and those from the NPR show a similar trend; with Stats SA figures always higher than the NPR figures (see Figure 3.1).

\subsection{Data processing}

Processing of death notification forms collected from the DHA takes place at Stats SA. The stages of data processing include sorting forms by year of death, pasting labels of unique identifiers on each form, coding sociodemographic variables and the causes of death, data capturing and analysis of data.

\section{Classification of the causes of death}

The mortality statistics released in this document are compiled in accordance with the World Health Organization (WHO) regulations that require that member nations classify and code causes of death in accordance with the current revision of the ICD-10 (WHO, 1992). The causes of death data presented were coded by procedures described in the Stats SA manual Guidelines for coders using ICD-10 (Stats SA, 2002). The ICD-10 coding provides the basic guidance used in virtually all countries to code and classify causes of death data. It provides information on coding in terms of disease, injury and poisoning categories. It also provides the rules for selecting the underlying cause of death from the several diagnoses that may be reported on the death notification form, as well as definitions, tabulation lists, guidelines for the death notification form, and regulations on the use of the classification. The ICD-10 contains approximately 8000 categories of causes of death. The classification has been constructed for convenience and its usage is not mandatory. The ICD-10 has been adopted by member states, and in South Africa, the National Health Information System of South Africa has also adopted it as its standard.

\footnotetext{
1 ICD-10 is the tenth revision of the International Classification of Diseases developed by the World Health Organization (WHO), which is followed worldwide in order to have a uniform way of classifying morbidity as well as causes of death.
} 
Stats SA follows the principle of 'what you see is what you code' in coding the information on causes of death provided by certifying officials. Furthermore, Stats SA has outlined specific guidelines for coding immunosuppression and acquired immune suppression which do not have codes in the ICD-10 manuals. In terms of the Stats SA coding procedures and guidelines, immunosuppression is coded as immunodeficiency, not as human immunodeficiency virus (HIV) disease. Certifying officials sometimes reported the underlying cause of death as acquired immune suppression. In terms of the Stats SA coding procedures, this term was interpreted as HIV disease and given an HIV code (group B20-B24). If HIV was written on the form, this was also coded in the HIV group, as required by the ICD-10. Codes U51 and U52 were assigned to multidrug-resistant tuberculosis (MDR-TB) and extensively drug-resistant tuberculosis (XDR-TB), respectively and included in the tuberculosis (A15-A19) broad group of causes of death.

\section{Automated generation of the underlying causes of death}

Once the causes of death given on the death notification forms were coded, the underlying causes of death were derived automatically, using a software program called Automated Classification of Medical Entities (ACME 2000.05) developed by the United States National Center for Health Statistics (NCHS). The ACME program applies the WHO rules on the selection of underlying causes of death. The ACME program is used as the international standard in the automated coding of causes of death.

The ACME program automatically derived the underlying cause of death for $98,5 \%$ of all records processed during the 2010/11 processing phase. The ACME system provides an editing user interface for cases to be resolved manually. This was required for some of the causes of death that are considered by the system as rare causes, such as cholera or causes such as multidrug-resistant tuberculosis and extensively drug-resistant tuberculosis that did not exist when the program was developed.

\subsection{Data analysis}

Data in this release are presented in tables and graphs, which show frequencies, percentage distributions, median ages, sex ratios, crude and age specific death rates. Median ages at death are used to measure the tempo of mortality, which indicates how rapidly or slowly, or how early or late mortality occurs in the population. Although both medians and means may be influenced by the quality of age reporting, medians are preferred over means since the distribution of mortality in age-time or duration-time is likely to be skewed.

Crude death rates (CDR) by sex were computed for the years 2005 to 2009 . They were calculated by dividing the number of deaths occurring in each year for each sex by the total population for each sex for that specific year, multiplied by 1000 . The mid-year population estimated by sex was used for the calculations (Stats SA, 2011). The crude death rates were also calculated for all deaths.

The analysis of information on causes of death was mainly based on ranking the underlying causes of death and providing proportions of deaths due to specific causes. Ranking the underlying causes of death is useful for illustrating the relative burden of cause-specific mortality. The ranking simply denotes the frequency of causes of death among those causes eligible to be ranked, and does not reflect the causes of death in terms of their importance from a public health point of view.

The top-ranking causes determine the leading causes of death. Causes that had the same number of deaths received the same rank and a rank was skipped for the next cause. For example, if two causes of death had the same frequency and were the top-ranking causes, they both received rank one, and the next cause received rank three. Due to concerns about violence and deaths due to accidents in South Africa, natural and non-natural causes of death have been ranked separately. Furthermore, in ranking natural underlying causes of death, symptoms, signs and abnormal clinical and laboratory findings, not elsewhere classified (R00-R99), were excluded as the information cannot be used effectively for public health policy and planning purposes. Although in some cases these causes would have been among the ten leading underlying causes, they are excluded from the ranking.

This release also presents tables on mortality and causes of death for district municipalities in the country, shown in the appendices. Information on local municipalities is also available, but is provided on request from Statistics South Africa. The boundaries for local municipalities, district municipalities and provinces are in line with the 2011 municipal boundaries. 


\section{$2.4 \quad$ Data quality}

Mortality and causes of death statistics can suffer from incomplete registration, missing data and causes of death attributed to ill-defined causes. Data quality for this release will assess completeness of death registration; the extent of late registrations; timeliness of death registration; completeness of information for selected variables; trends in ill-defined causes of death; and then apply the Mahapatra et al. (2007) framework to summarise the quality of mortality and cause-of-death statistics.

\subsubsection{Completeness of death registration}

Past releases on mortality and causes of death used the Preston and Hill (1980) method to estimate completeness of death registration in South Africa. Although this method had known limitations (such as the assumption on stability and dependency on intercensal growth rates), it was preferred over others due to less input requirements for the estimation and the fact that it provides estimates of completeness of death registration on an annual basis. The Preston and Hill (1980) method was deemed inappropriate for the estimation of the completeness for 2009 death data as we shift further away from 2007 when the Community Survey was conducted, and with consideration of the instability of the South African population.

Methods of estimating the completeness of death registration that do not assume a stable population include the Generalised Growth Balance (Hill, 1987) and the Synthetic Extinct Generations (Bennett and Horiuchi 1981, 1984) methods. These methods have been applied to estimate the completeness of death registration in South Africa [see for example, Dorrington and Bradshaw (2011); Khoza (forthcoming)] for the intercensal periods 1996-2001 and 2001-2007. While these methods are appropriate for the South African situation, their main disadvantage is that they provide completeness of death registration over an intercensal period, not on an annual basis. As such, estimates of completeness of death registration from 2008 will only be possible once the data from the 2011 population census are available.

The results from Dorrington and Bradshaw (2011) and Khoza (forthcoming) suggest that the completeness of death registration in South Africa between 2001 and 2007 was about $90 \%$ or more. In line with the recommendation of the Department of Health (2011: 53), completeness of death registration for 2009 is assumed to be $93 \%$, taking into consideration that death registration continues to improve in the country.

\subsubsection{Late registrations}

The current processing phase (2010/11) included death notification forms for deaths that occurred in 2009 as well as additional death notification forms for the years 1997-2008 that had not been received by Stats SA in the previous processing phases. Table 2.1 provides information on the number of deaths published in November 2010 for the years 1997-2008; additional forms received during the current processing phase for these years; and the total number of deaths for each year as of September 2011.

In total, 5044 additional death notification forms for 1997-2008 were processed during 2010/11 (excluding duplicates). The majority of the late registrations processed in $2010 / 11(61,0 \%)$ were late registrations for deaths that occurred in 2008. The distribution of the updated deaths from 1997 to 2008 and for 2009 deaths by age and sex is provided in Appendices C (1997-1999), C.1 (2000-2002), C.2 (2003-2005), C.3 (2006-2008) and C.4 (2009). 
Table 2.1: Number of deaths published in November 2010 and late registrations processed during the 2010/11 processing phase by year of death, 1997-2008

\begin{tabular}{|l|r|r|r|}
\hline $\begin{array}{l}\text { Year of } \\
\text { death }\end{array}$ & $\begin{array}{r}\text { Number of deaths published in } \\
\text { November 2009 }\end{array}$ & $\begin{array}{r}\text { Additional forms received in the } \\
\text { 2010/11 processing phase }\end{array}$ & $\begin{array}{r}\text { Total number of deaths } \\
\text { (by September 2011) }\end{array}$ \\
\hline 1997 & 317132 & 19 & 317151 \\
\hline 1998 & 365853 & 14 & 365867 \\
\hline 1999 & 381820 & 19 & 381839 \\
\hline 2000 & 416155 & 161 & 416316 \\
\hline 2001 & 454882 & 89 & 454971 \\
\hline 2002 & 502050 & 83 & 502133 \\
\hline 2003 & 556779 & 103 & 556882 \\
\hline 2004 & 576709 & 100 & 576809 \\
\hline 2005 & 598131 & 109 & 598240 \\
\hline 2006 & 612778 & 262 & 613040 \\
\hline 2007 & 603094 & 1006 & 604100 \\
\hline 2008 & 592073 & 3079 & 595152 \\
\hline Total & $\mathbf{5 9 7 7 4 5 6}$ & $\mathbf{5 0 4 4}$ & $\mathbf{5 9 8 2 5 0 0}$ \\
\hline
\end{tabular}

\subsubsection{Timeliness of death registration}

Information pertaining to the date of death registration is captured at Stats SA from which the number of days it takes for a death to be registered following its occurrence can be calculated. Table 2.2 shows the distribution of the number of days it took for deaths that occurred in 2009 to be registered. About $11,2 \%$ of deaths were registered within the day of occurrence and about a quarter $(24,8 \%)$ a day after they occurred. Over half $(54,7 \%)$ of the deaths that occurred in 2009 were registered within two days of the occurrence of death; and two-thirds within three days. A large percentage $(88,2 \%)$ of deaths were registered by the first week of death, and nearly all deaths $(97,7 \%)$ were registered within the first month of occurrence. Less than $1 \%$ of deaths were registered after one year of death.

Following death registration, which takes place in regional offices, hospitals or mobile units manned by the DHA, the forms are forwarded to the DHA head office for further processing. Subsequently, the forms are collected by Stats SA for processing.

Table 2.2: Distribution of deaths by the number of days it takes to register a death, 2009

\begin{tabular}{|l|r|r|r|}
\hline Number of days & Number of deaths & $\%$ & Cumulative \% \\
\hline Within a day of death & 64314 & 11,2 & 11,2 \\
\hline 1 day & 141739 & 24,8 & 36,0 \\
\hline 2 days & 107089 & 18,7 & 54,7 \\
\hline 3 days & 79859 & 13,9 & 68,6 \\
\hline 4 days & 55189 & 9,6 & 78,3 \\
\hline 5 days & 35019 & 6,1 & 84,4 \\
\hline 6 days & 21736 & 3,8 & 88,2 \\
\hline $14-20$ days & 49483 & 8,6 & 96,8 \\
\hline $21-30$ days & 4870 & 0,9 & 97,7 \\
\hline $31-364$ days & 13012 & 2,3 & 99,9 \\
\hline 1 year + & 363 & 0,1 & 100,0 \\
\hline Total & $\mathbf{5 7 2} \mathbf{6 7 3}$ & $\mathbf{1 0 0 , 0}$ & \\
\hline
\end{tabular}




\subsubsection{Completeness of information for selected variables}

Other indicators of completeness of information published in this release are based on the percentage of cases where information was unknown or unspecified for specific variables, taking into consideration the applicable subset of the population. Unknown cases refer to cases where more than one option was selected or where the information could not be classified according to specified categories. Unspecified cases are those where there was no response provided.

Table 2.3 shows that less than $1 \%$ of deaths had unknown or unspecified information for sex $(0,2 \%)$, age $(0,2 \%)$ and province of death occurrence $(0,2 \%)$. About $10 \%$ of the deaths had unknown or unspecified information on province of residence $(10,0 \%) ; 14,3 \%$ on place or institution of death occurrence; and $18,8 \%$ on marital status. For a relatively large percentage of deaths, the method used to ascertain cause of death was unspecified $(21,3 \%)$, province of birth was unknown or unspecified $(21,8 \%)$, and population group was not recorded $(26,2 \%)$. More than half of all deaths had unknown or unspecified level of education, smoking status, pregnancy status, occupation and industry. There have not been any notable changes in reporting these variables over time.

In this release, no analyses were undertaken for all variables where more than half of the deaths had unknown or unspecified information. However, unit records of data that include these variables are provided for further analysis. A dataset containing unit records of data on recorded deaths for 2009 is available on request from Stats SA.

Table 2.3: Percentage of deaths classified as unknown/unspecified for selected variables, 2009

\begin{tabular}{|l|r|r|}
\hline Variables & Applicable group & $\begin{array}{r}\% \text { unknown or } \\
\text { unspecified }\end{array}$ \\
\hline Sex & All & 0,2 \\
\hline Age & All & 0,2 \\
\hline Province of death occurrence & All & 0,2 \\
\hline Province of usual residence of deceased & All & 10,0 \\
\hline Place or institution of death occurrence & All & 14,3 \\
\hline Marital status & All & 18,8 \\
\hline Method used to ascertain cause of death & All & 21,3 \\
\hline Province of birth & All & 21,8 \\
\hline Population group & Females aged 10-55 & 26,2 \\
\hline Education & Aged 15 and older & 54,7 \\
\hline Smoking status & Aged 15 and older (economically active) & 56,1 \\
\hline Pregnancy status & & 74,0 \\
\hline Occupation & & 76,0 \\
\hline Industry & & \\
\hline
\end{tabular}

\subsubsection{Quality of causes of death information}

The quality of causes of death information may be assessed by the percentage of deaths due to symptoms, signs and abnormal clinical and laboratory findings not elsewhere classified and specifically those due to ill-defined and unknown causes of mortality. This group includes all ill-defined conditions for which no diagnosis classified elsewhere is recorded. For practical purposes, these categories could be designated as not otherwise specified, or as unknown etiology, or as transient.

Table 2.4 shows that the percentage of deaths due to symptoms, signs and abnormal clinical and laboratory findings not elsewhere classified during 1997 to 2009 was between $12 \%$ and $14 \%$ and did not change much over these 13 years. Similarly, the percentage of deaths due to ill-defined and unknown causes of mortality ranged between $10 \%$ and $13 \%$, with no apparent pattern over time. The small difference between the whole chapter of symptoms, signs and abnormal clinical and laboratory findings not elsewhere classified and the broad group of illdefined and unknown causes of mortality shows that a great majority (over $90 \%$ ) of deaths due to symptoms, signs 
and abnormal clinical and laboratory findings not elsewhere classified were ill-defined and unknown causes of mortality - a group that includes sudden infant death syndrome, other sudden death with cause unknown, unattended death and other ill-defined and unspecified causes of mortality.

Table 2.4: Percentage of deaths classified to symptoms, signs and abnormal clinical and laboratory findings not elsewhere classified, 1997-2009

\begin{tabular}{|c|c|c|}
\hline Year of death & $\begin{array}{c}\text { \% of deaths due to symptoms, signs and abnormal } \\
\text { clinical and laboratory findings not elsewhere } \\
\text { classified (R00-R99) }\end{array}$ & $\begin{array}{c}\text { \% of deaths due to ill-defined and } \\
\text { unknown causes of mortality } \\
\text { (R95-R99) }\end{array}$ \\
\hline 1997 & 13,2 & 11,5 \\
\hline 1998 & 13,8 & 12,0 \\
\hline 1999 & 12,2 & 10,4 \\
\hline 2000 & 12,4 & 10,4 \\
\hline 2001 & 12,6 & 10,9 \\
\hline 2002 & 12,5 & 10,7 \\
\hline 2004 & 12,5 & 10,7 \\
\hline 2005 & 12,3 & 11,1 \\
\hline 2007 & 12,4 & 11,4 \\
\hline 2008 & 13,6 & 12,5 \\
\hline 2009 & 13,9 & 13,0 \\
\hline
\end{tabular}

\subsubsection{Assessment framework for death registration data}

Several frameworks for assessment of death registration data have been proposed by different researchers. For the purpose of this statistical release, the framework proposed by Mahapatra et al. (2007) is used to assess the quality of the 2009 death statistics from civil registration system. Mahapatra et al. (2007) proposed two categories, namely, general vital statistics and cause-of-death statistics. Criteria under these categories include accuracy, relevance, comparability, timeliness and accessibility.

Table 2.5 shows the results of the assessment framework for the 2009 mortality and causes of death data from the South African civil registration system, modified due to availability of information required. About $93 \%$ of deaths for 2009 were covered by the civil registration system, with both age and sex generally well-reported. The information on province of birth and population group was not well reported as over $20 \%$ for each variable had missing information. The relevance and comparability of mortality statistics is regarded as complete.

About half $(48,6 \%)$ of the deaths occurred within a healthcare facility and $13,7 \%$ of all deaths were assigned illdefined causes. The information on mortality is highly relevant and comparable over time. Based on routine tabulations by sex and 5-year age groups as well as the fact that tabulation of cause-of-death information is provided for the 9 provinces and 52 district municipalities in the country, relevance of cause-of-death statistics is regarded as completely relevant. Furthermore, the proportions of cause specific mortality are consistent between 2008 and 2009 and the international classification of diseases (10 ${ }^{\text {th }}$ revision) is used for coding causes of death. Therefore, comparability is also considered complete.

The table further shows that there is wide accessibility to statistical releases and data sets published on mortality and causes of death. However, it takes about 18 months to process the data at Stats SA, with more time required to send the death notification forms from the regional offices where the deaths are registered to head office for further processing before they can be collected by Stats SA. The mean time from end of reference period to publication is about two years. 


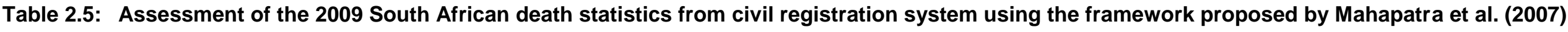

\begin{tabular}{|c|c|c|c|}
\hline \multicolumn{2}{|l|}{ General vital statistics } & \multicolumn{2}{|c|}{ Cause-of-death statistics } \\
\hline Criteria and indicators & Measure & Criteria and indicators & Measure \\
\hline $\begin{array}{l}\text { Accuracy }(\%) \\
\text { Completeness of death registration }\end{array}$ & $93 \%$ & $\begin{array}{l}\text { Accuracy } \\
\text { Proportion of deaths that occurred in healthcare } \\
\text { facilities }\end{array}$ & $48,6 \%$ \\
\hline Missing data & & $\begin{array}{l}\text { Proportion of deaths assigned to symptoms and signs } \\
\text { of disease not elsewhere classified }\end{array}$ & $13,7 \%$ \\
\hline Population group & $26,2 \%$ & & \\
\hline Province of birth & $21,8 \%$ & & \\
\hline Province of residence & $10,0 \%$ & & \\
\hline Age & $0,2 \%$ & & \\
\hline Sex & $0,2 \%$ & & \\
\hline Relevance & & Relevance & \\
\hline Routine tabulations by sex and 5-year age groups & $100 \%$ & Routine tabulation by sex and 5-year age groups & $100 \%$ \\
\hline $\begin{array}{l}\text { Deaths in children under five years tabulated by } 0 \text { and } \\
1-4 \text { year age group }\end{array}$ & $100 \%$ & Number of cause-of-death tabulation areas & $\begin{array}{l}9 \text { Provinces and } 52 \text { district } \\
\text { municipalities }\end{array}$ \\
\hline $\begin{array}{l}\text { Comparability } \\
\text { Stability of key definitions over time }\end{array}$ & $100 \%$ & $\begin{array}{l}\text { Comparability } \\
\text { Consistency of cause specific mortality proportions } \\
\text { over consecutive years }\end{array}$ & $100 \%$ \\
\hline Uniformity of definitions across areas & $100 \%$ & $\begin{array}{l}\text { ICD coding for certification and coding of causes of } \\
\text { deaths, revision used and code level to which } \\
\text { tabulations are published }\end{array}$ & $\begin{array}{l}\text { No coding for certification; coding } \\
\text { causes of death using the tenth } \\
\text { revision at 3-digit level }\end{array}$ \\
\hline \multicolumn{4}{|l|}{ Timeliness } \\
\hline Processing time & \multicolumn{3}{|l|}{18 months } \\
\hline Mean time from end of reference period to publication & \multicolumn{3}{|l|}{ Two years } \\
\hline \multicolumn{4}{|l|}{ Accessibility } \\
\hline Media - number of formats in which data are released & \multicolumn{3}{|c|}{ Two: website and compact discs } \\
\hline Metadata & \multicolumn{3}{|c|}{ Published with compact disc and available on request } \\
\hline Availability of user service & \multicolumn{3}{|c|}{ Email: info@statssa.gov.za / Tel: 0123108600 / Fax (012) 3108500 / 8495} \\
\hline
\end{tabular}




\section{Registered deaths}

This section provides the distribution of deaths that occurred in 2009 by age, sex, population group, marital status, place or institution of death occurrence, province of death occurrence and province of usual residence of the deceased. The overall number of deaths is also provided by year of death for the period 1997-2009 to show recent trends in mortality using updated data that include late registrations processed in 2010/11.

\subsection{Levels and trends of registered deaths}

Figure 3.1 shows the number of registered deaths processed by Stats SA and those recorded on the National Population Register (NPR) maintained by the Department of Home Affairs (DHA) for the period 1997-2009. Overall, the number of deaths processed by Stats SA for all years was higher than that recorded on the NPR. It is also observed that the number of registered deaths for both sources increased consistently for each year from 1997 to 2006, after which they decreased.

The number of deaths processed by Stats SA in 2009 was 572673 , indicating a decrease of $3,8 \%$ from a total of 595152 deaths that had occurred in 2008 and were registered. The number of deaths on the NPR declined by 2,5\% during the same period (from 545903 in 2008 to 532461 in 2009). Between 2007 and 2008, the number of deaths decreased by $1,5 \%$ and $1,3 \%$ for deaths processed by Stats SA and those on the NPR, respectively.

Figure 3.1: Number of registered deaths by source of data and year of death, 1997-2009*

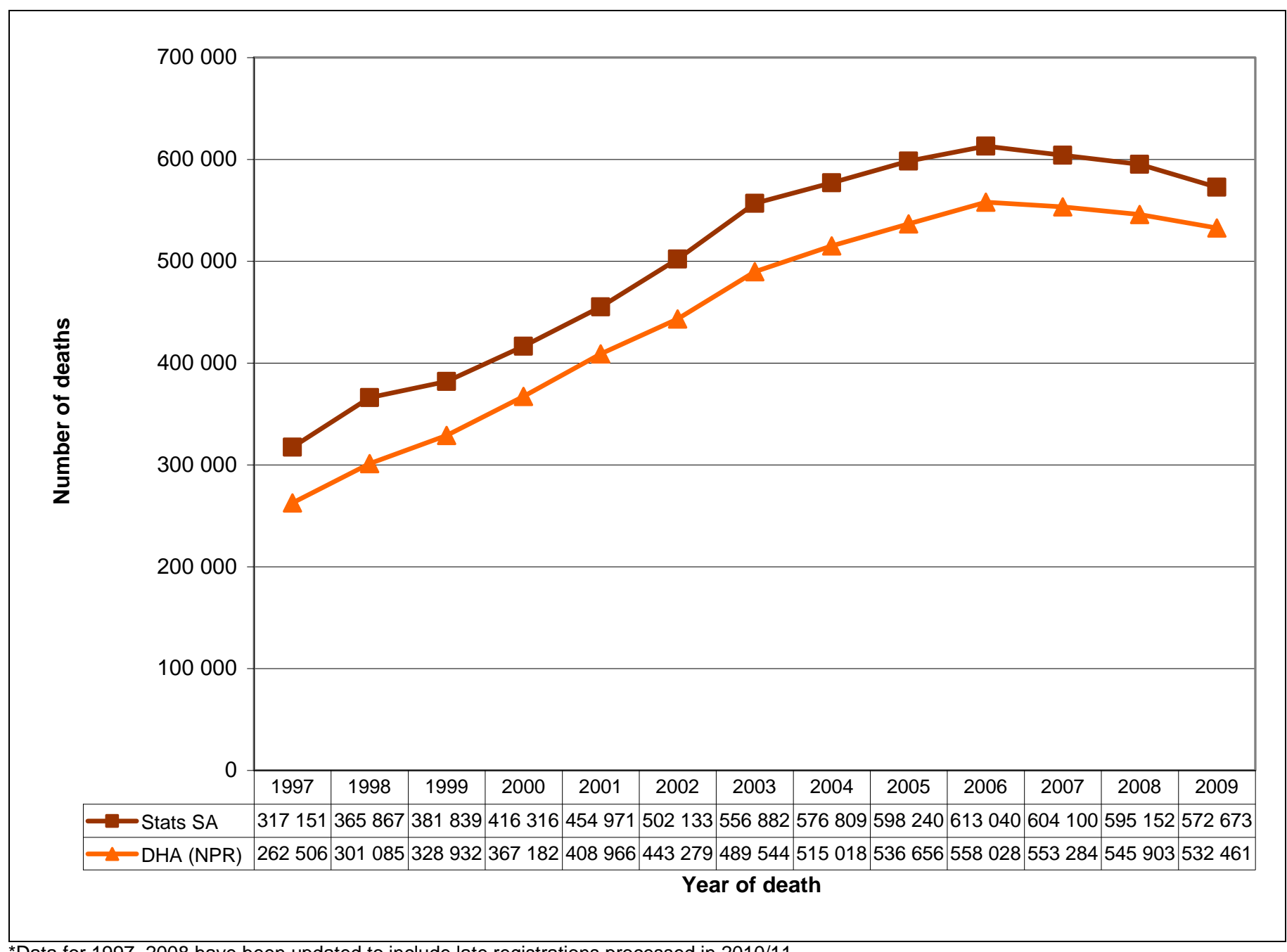

${ }^{*}$ Data for 1997-2008 have been updated to include late registrations processed in 2010/11. 


\subsection{Age differentials}

Table 3.1 shows that $6,6 \%$ of deaths occurred within the first year of life, with the contribution of this age having decreased from 7,7\% as observed with the 2008 deaths (see Figure 3.2). A comparison of the remaining ages shows that the highest number of deaths that occurred in 2009 was among those aged 35-39 and 30-34 years, comprising respectively $8,6 \%$ and $8,5 \%$ of all deaths. These age groups were followed by those aged $40-44$ $(7,6 \%)$. The lowest percentage of deaths was among those aged 5-9 and $10-14$ years (each comprising $0,8 \%$ of all deaths).

Table 3.1: Number and percentage distribution of deaths by age, 2009

\begin{tabular}{|l|r|r|}
\hline Age group & Number & Percentage \\
\hline 0 & 37974 & 6,6 \\
\hline $1-4$ & 12497 & 2,2 \\
\hline $5-9$ & 4313 & 0,8 \\
\hline $10-14$ & 4397 & 0,8 \\
\hline $15-19$ & 8697 & 1,5 \\
\hline $20-24$ & 21434 & 3,7 \\
\hline $25-29$ & 38792 & 6,8 \\
\hline $30-34$ & 48446 & 8,5 \\
\hline $35-39$ & 49396 & 8,6 \\
\hline $40-44$ & 43743 & 7,6 \\
\hline $45-49$ & 41147 & 7,2 \\
\hline $50-54$ & 37940 & 6,6 \\
\hline $55-59$ & 36426 & 6,4 \\
$60-64$ & 33189 & 5,8 \\
$65-69$ & 33507 & 5,9 \\
\hline $70-74$ & 30783 & 5,4 \\
$75-79$ & 30167 & 5,3 \\
\hline $80-84$ & 24614 & 4,3 \\
\hline $85-89$ & 17154 & 3,0 \\
$90+$ & 16768 & 2,9 \\
\hline Unspecified & 1289 & 0,2 \\
\hline Total & 572673 & $\mathbf{1 0 0 , 0}$ \\
\hline
\end{tabular}

The distributions of deaths by age and year of death for the past five years (2005 to 2009) are shown in Figure 3.2 to provide an indication of the age pattern of mortality over time. Absolute numbers are provided in Appendices C.2 to C.4, which show that for all the years, the lowest number of deaths occurred in age groups 5-9 and 10-14 and the highest number occurred in age groups 30-34 and 35-39. The number of deaths between 2008 and 2009 decreased consistently for age groups younger than 60 years, with the exception of age group 10-14, and generally increased for ages 60 and older.

A general pattern observed in Figure 3.2 is that the age pattern of mortality was generally the same over the fiveyear period. Furthermore, the proportion of deaths decreased consistently over the five-year period for infants and for middle ages (from age group 20-24 up to 40-44) and increased at older ages (age group 50-54 and older). While the proportion of deaths was highest in age group 30-34 between 2005 and 2008, it shifted to age group 35-39 in 2009. The comparison between deaths occurring in 2008 and 2009 shows notable decreases in the number of deaths at ages 0 and 30-34. Conversely, there was a marked increase in the proportions dying at older ages. 


\section{Figure 3.2: Percentage distribution of deaths by age and year of death, 2005-2009*}

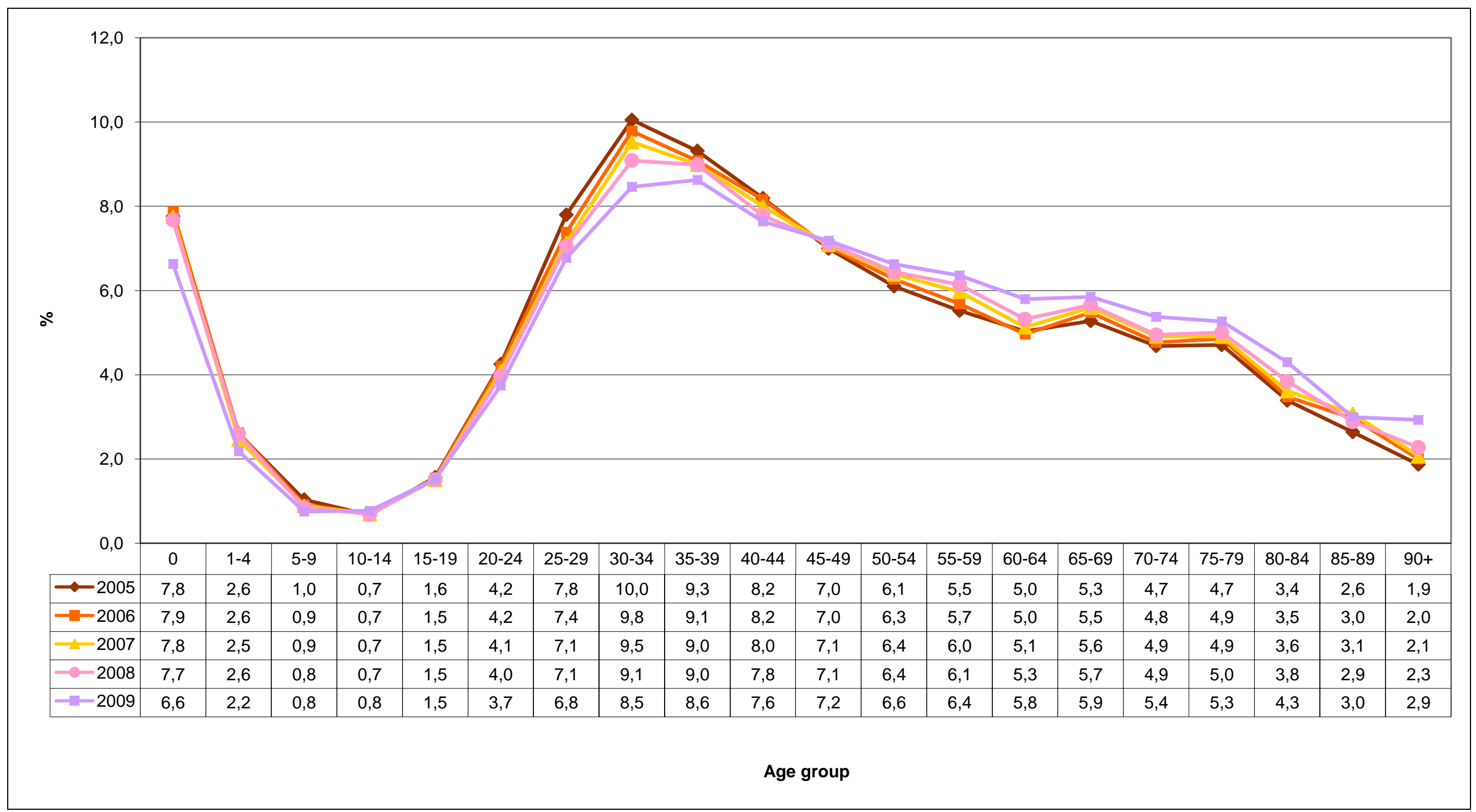

* (1) Excluding deaths with unspecified age (3 277 deaths in 2005; 1364 deaths in 2006; 1237 deaths in 2007; 1042 in 2008 and 1289 deaths in 2009).

(2) Data for 2005-2008 have been updated to include late registrations processed in 2010/11. 


\subsection{Sex differentials}

The distribution of the number of deaths by sex shows that there were slightly more male $(51,4 \%)$ than female deaths $(48,4 \%)$ in 2009 . About $0,2 \%$ of the deaths had unspecified information on the sex of the deceased. Since 1997, over half of all deaths were males (See Figure 3.3). However, the contribution of male deaths to the total number of deaths decreased from 1998, reaching its lowest point in 2005 when there were almost as many male deaths as female deaths. From 2006 to 2009 the proportion of male deaths increased, and vice versa for female deaths. The percentage distribution of deaths by sex from 1997-2009 indicates that the gap between male and female deaths generally narrowed down over time up to 2005 , but appear to be widening again gradually over time.

\section{Figure 3.3: Percentage distribution of deaths by sex and year of death, 1997-2009*}

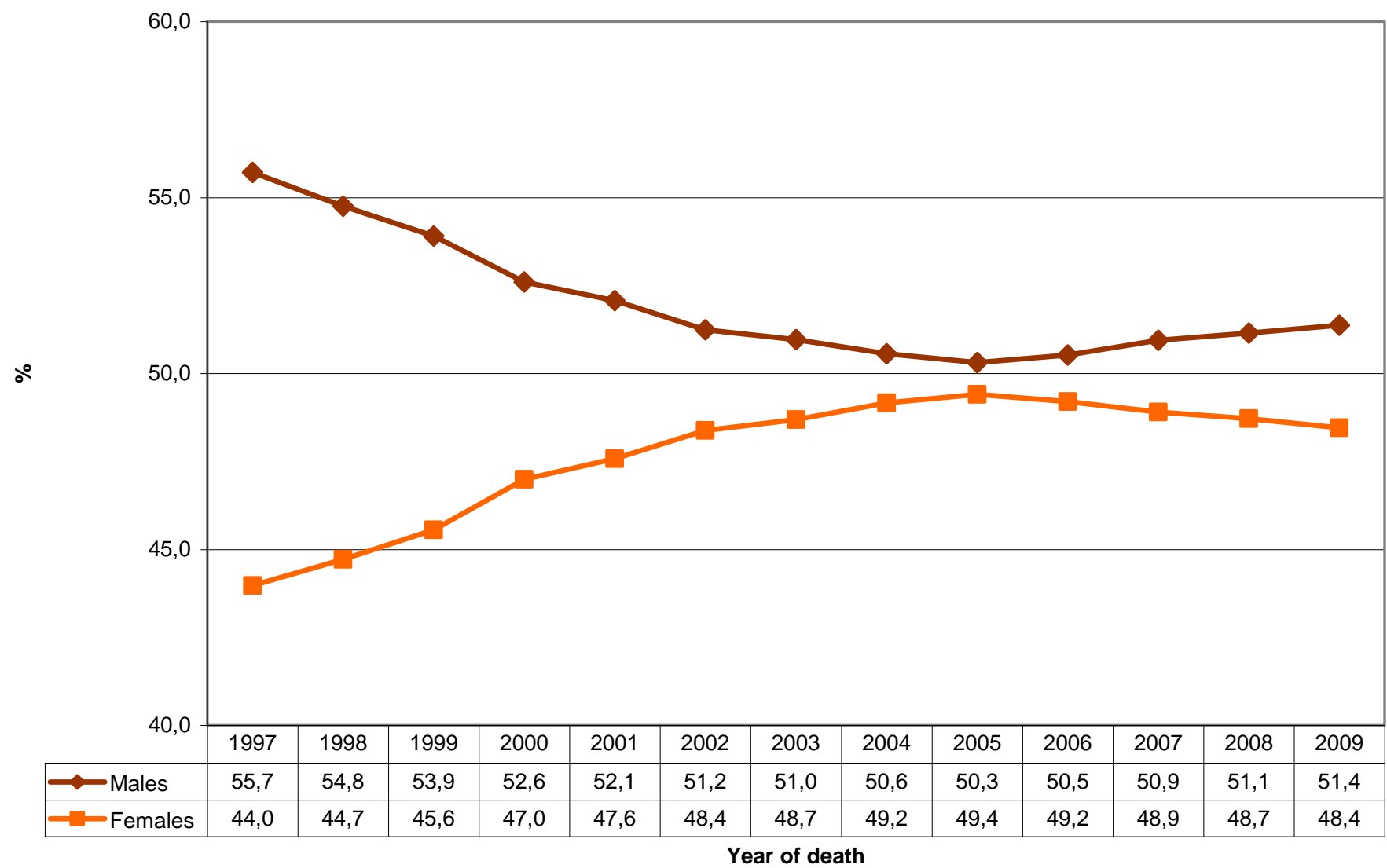

(1) Excluding deaths with unspecified sex: (1 028 deaths in 1997; 1928 deaths in 1998; 2077 deaths in 1999; 1721 deaths in $2000 ; 1646$ deaths in 2001, 1944 deaths in 2002; 1973 deaths in 2003; 1615 deaths in 2004; 1719 deaths in 2005; 1741 deaths in 2006,988 deaths in 2007; 826 in 2008 and 1053 in 2009).

(2) Data for 1997-2008 updated to include late registrations processed in 2010/11.

The annual percentage changes in the number of deaths and year of death are shown in Appendix $\mathrm{D}$. It is observed that from 1997 to 2005, female deaths increased at a higher rate than male deaths. This trend changed between 2005 and 2006 when the increase was higher for males. During the years 2006-2007, 2007-2008 and 2008-2009, the number of deaths for both males and females decreased, with higher decreases observed for females as compared to males for each of the three periods. Between 2008 and 2009, male deaths decreased by 3,4\% while female deaths decreased by $4,3 \%$.

Crude death rates (CDR) by sex were calculated for the period 2005-2009 using deaths adjusted for incompleteness to show sex differences in mortality, taking into account the population size for each sex. The 2005-2007 data were adjusted by $90 \%$ completeness of death registration while the 2008-2009 were adjusted by $93 \%$. Figure 3.4 shows that crude death rates increased slightly between 2005 and 2006 for both males and females, after which they consistently decreased. The rates for both sexes are consistent with those reported in the mid-year population estimates (Stats SA, 2011). Over the five years, mortality rate was slightly higher for males as compared to females. In 2009, the crude rate for males was 13 deaths per 1000 population, 12 deaths per 1000 for females and the overall rate was 12 deaths per 1000 population. 
Figure 3.4: Crude Death Rates (CDR) by year of death and sex (adjusted number of deaths), 2005-2009*

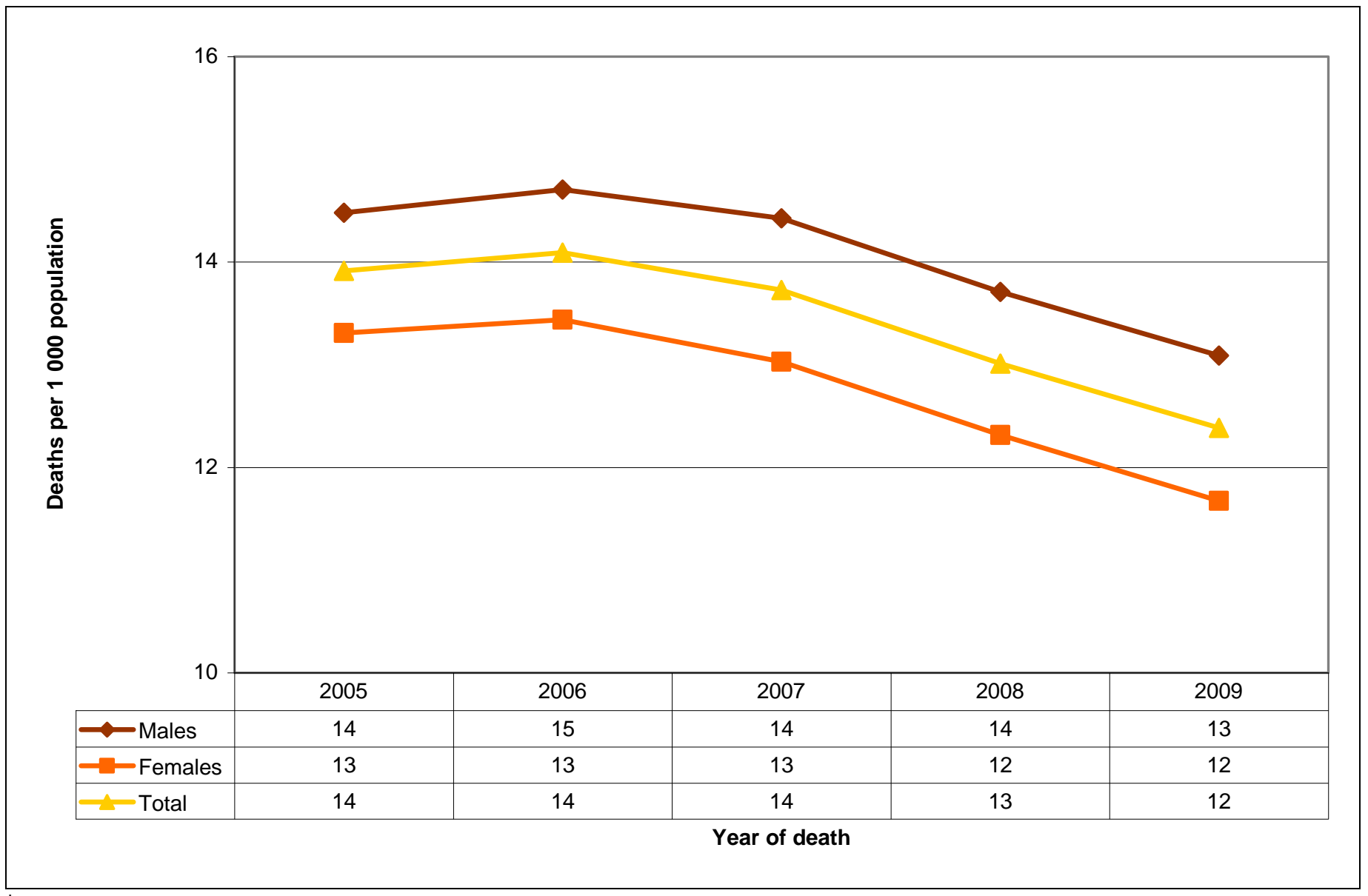

${ }^{*}$ Data for 2005-2008 have been updated to include late registrations processed in 2010/11.

Age specific death rates (ASDRs) for the total population for the period 2005-2009 (deaths adjusted for incompleteness) are shown in Appendix $E$ to provide an indication of the age pattern of mortality over the five-year period, taking into consideration population size at each age. Generally, the age pattern of death was the same for the five-year period, with rates higher at age 0 and from 60 years. Death rates for all years increased consistently from age group 50-54, reaching their highest levels at ages 80 and older. The rates were much lower between age groups 5-9 and 15-19. There is a noticeable drop in death rates in 2009 for most age groups, more so at age 0 and from age group 30-34 up to $40-44$.

\subsection{Age and sex differentials}

\section{Percentage distribution}

The age and sex percentage distribution of deaths that occurred in 2009 is shown in Figure 3.5 (absolute numbers are provided in Appendix C.4). The absolute number of deaths shows that female deaths exceeded male deaths at ages 20-29 and from age group 70-75 up to age 90 and older. The highest percentage of male deaths occurred among those aged $35-39(9,3 \%)$, followed by age group $30-34(8,4 \%)$ and age group $40-44(8,4 \%)$. For female deaths, the highest percentage of deaths was among those aged 30-34 (8,6\%), followed by those aged 35-39 $(8,0 \%)$ and those aged $25-29(7,7 \%)$. About $6,9 \%$ and $6,2 \%$ of male and female deaths, respectively, occurred at age 0 . For both males and females, the lowest percentage of deaths occurred among those aged 10-14 and 5-9.

The proportion of male deaths exceeded those of female deaths for deaths occurring from people at age group 0 to age group 15-19 as well as from age group 35-39 to age group 65-69. The gap in the proportions of deaths for males and females is particularly conspicuous between age groups 35-39 and 60-64. Proportions of male deaths decreased sharply and consistently from age group 35-39 while those for females decreased modestly from age group 30-34, increasing slightly from age group 65-69 after which they decreased again. 
Figure 3.5: Percentage distribution of deaths by age and sex, 2009*

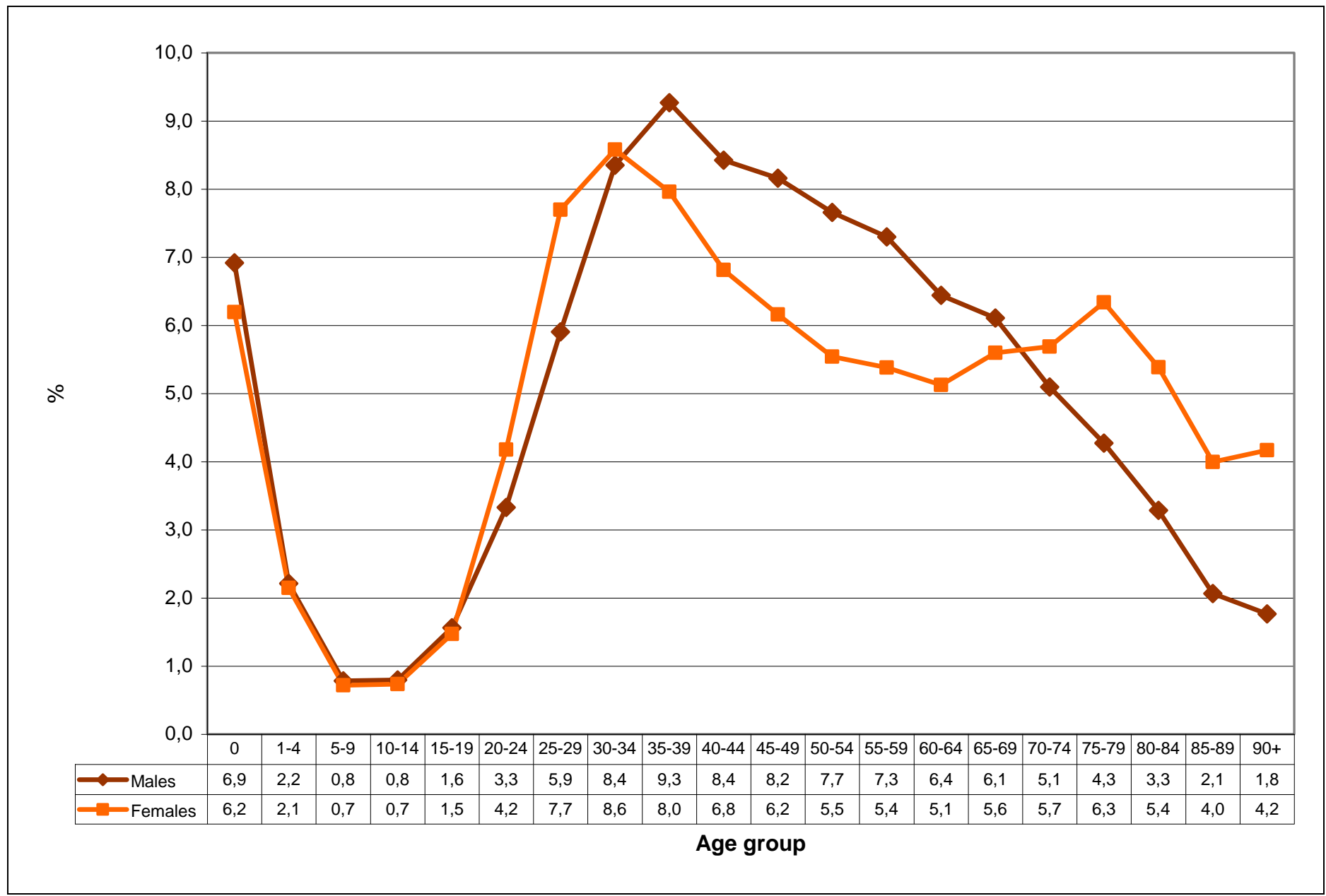

${ }^{*}$ Excluding 2219 deaths with unspecified age and unspecified sex.

\section{Median ages at death by sex}

The median ages at death by sex are presented in Figure 3.6. Median ages show how early or late mortality occurs in the population and specifies the age at which half of the reported deaths occur. Lower median ages at death indicate that mortality is occurring earlier while higher median ages indicate that mortality is occurring later.

Generally, the median ages at death for both males and females decreased from 1997 and reached their lowest levels in 2004. The decrease was more pronounced for females, which shows that mortality increased at a higher rate for females as compared to males. From 2005, the median ages increased again gradually for both sexes, indicating decreasing mortality.

The median ages at death for females was higher than that of males from 1997 to 2001, showing that mortality was occurring earlier for males and later for females during this period. The median ages then converged in 2002, after which they deviated again up to 2007, with median ages higher for males than for females. By 2007, the median age at death for both males and females was around 44 years, increasing to about 45 years in 2008 . The median ages for females (47,8 years) exceeded those for males (46,4 years) again in 2009.

The results generally show that between 1997 and 2002, females died at a later age than males on average, a pattern that was reversed between 2003 and 2007 when on average males died later than females. However, it is observed that the pattern is changing again in 2009 , with females dying at a later age than males. 
Figure 3.6: Median ages at death by sex and year of death, 1997-2009*

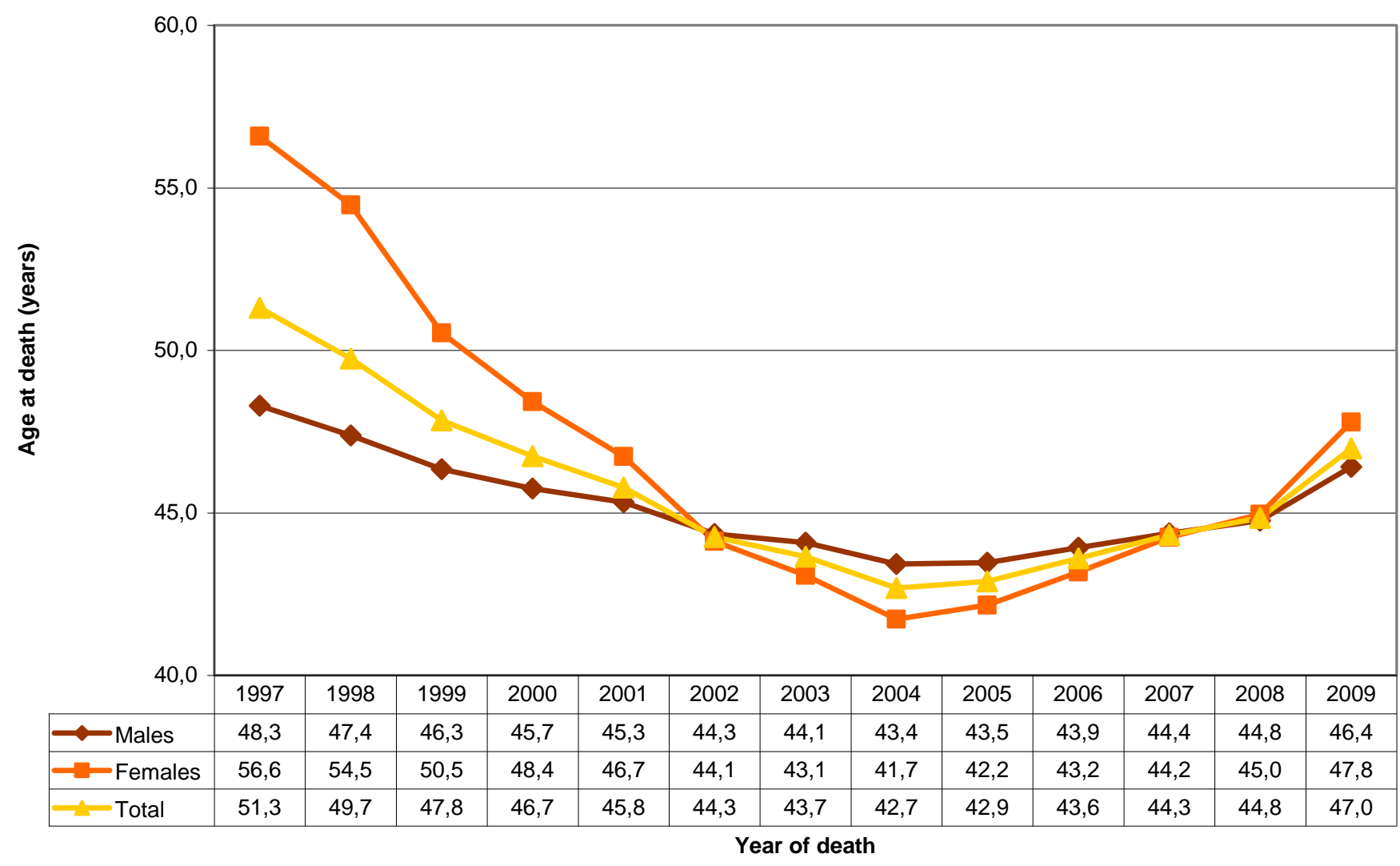

Data for 1997-2008 have been updated to include late registrations processed in 2010/11.

\section{Sex ratios by age}

The sex ratio of deaths (the number of male deaths per 100 female deaths) is another measure that shows the relative number of male to female deaths. A ratio of 100 indicates that there is an equal number of male and female deaths, a number less than 100 indicates more female death occurrences; and a number more than 100 indicates more male death occurrences.

The overall sex ratios for 1997-2009 are shown in Appendix F. The sex ratio for 2009 deaths was 106 male deaths per 100 female deaths, indicating that there were more male than female deaths that occurred in 2009. Over the 13year period, sex ratios at death have always been over 100, showing that male deaths have always exceeded female deaths. However, sex ratios decreased from 127 male deaths per 100 female deaths in 1997 to 102 male deaths per 100 female deaths in 2005. Sex ratios then increased by one male death per 100 female deaths every year from 2005 to 2009 .

Figure 3.7 shows the sex ratios for the years $2005-2009$ by age. It is observed that the age pattern of sex ratios was similar during these years. Generally, there were more male than female deaths from age 0 up to age group 15-19 and at age groups 35-39 up to 65-69. Female deaths exceeded male deaths at age groups 20-24 to 30-34 (with the exception of 2009) and from age group 70-74. Sex ratios consistently declined with age from age group 60-64.

The sex ratios by year of death for age groups 20-24, 25-29 and 30-34 (the young ages where sex ratios are below 100 ) show a consistent increase since 2005. This indicates that female deaths were decreasing much more than male deaths in these ages. For example, between 2008 and 2009, female deaths in age group 20-24, decreased by 10,1\% while male deaths in the same age group decreased by $8,5 \%$. In age group 25-29, female and male deaths decreased by $9,2 \%$ and $5,8 \%$, respectively. 
Figure 3.7: Sex ratios by age and year of death, 2005-2009*

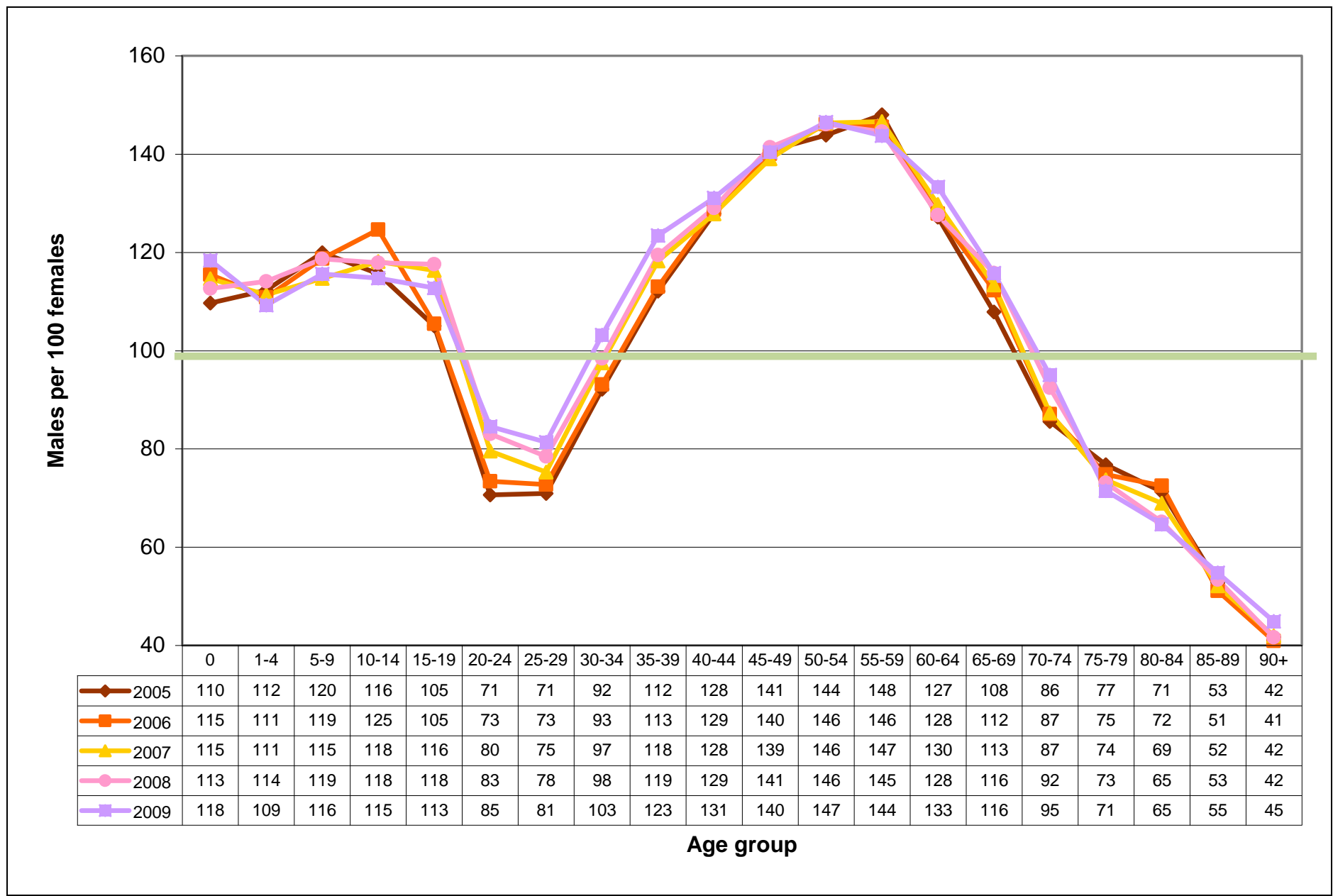

* (1) Excluding deaths with unspecified sex: (1 719 deaths in 2005; 1741 deaths in 2006, 988 deaths in 2007; 826 in 2008 and 1053 in 2009).

(2) Data for 2005-2008 have been updated to include late registrations processed in 2010/11.

\subsection{Population group differences in mortality}

The distribution of deaths by population group is shown in Table 3.2. It is observed that black Africans contributed the highest percentage of registered deaths $(61,7 \%)$ while Indian or Asians had the lowest percentage $(1,3 \%)$. About $6,3 \%$ of the deaths occurred to the white population group and $4,4 \%$ to the coloured population group. This distribution is largely similar to that observed in the previous years.

Over a quarter $(26,2 \%)$ of registered deaths in 2009 had population group classified as 'other', unspecified or unknown. Therefore, the results on population groups have to be treated with caution due to this high percentage of unknown, unspecified, or 'other' population groups. The poor reporting of population group during death registration has persisted since 1997.

Table 3.2: Number and percentage distribution of deaths by population group, 2009

\begin{tabular}{|l|r|r|}
\hline Population group & Number & Percentage \\
\hline Black African & 353607 & 61,7 \\
\hline Coloured & 25178 & 4,4 \\
Indian or Asian & 7467 & 1,3 \\
White & 36260 & 6,3 \\
\hline Other, unknown or unspecified & 150161 & 26,2 \\
\hline Total & $\mathbf{5 7 2 6 7 3}$ & $\mathbf{1 0 0 , 0}$ \\
\hline
\end{tabular}




\subsection{Marital status differences in mortality}

Table 3.3 shows that nearly half $(47,1 \%)$ of the deceased were reported as never married at the time of death. About a quarter $(24,3 \%)$ of the deceased were married or living with a partner as married people at the time of death while $8,3 \%$ were widowed and $1,6 \%$, were divorced. The marital status of the deceased at the time of death was unknown or unspecified in $18,8 \%$ of the deaths.

Table 3.3: Number and percentage distribution of deaths by marital status, 2009

\begin{tabular}{|l|r|r|}
\hline Marital status & Number & Percentage \\
\hline Never married & 269500 & 47,1 \\
\hline Married or living as married & 139244 & 24,3 \\
Widowed & 47491 & 8,3 \\
\hline Divorced & 8908 & 1,6 \\
\hline Unknown or unspecified & 107530 & 18,8 \\
\hline Total & $\mathbf{5 7 2} 673$ & $\mathbf{1 0 0 , 0}$ \\
\hline
\end{tabular}

\subsection{Differences in mortality by place or institution of death occurrence}

The number of deaths by place or institution of death occurrence shows that about $44,7 \%$ of the deaths took place in hospitals, $1,7 \%$ in hospital emergency rooms or as outpatients and $2,2 \%$ died in a nursing home (see Table 3.4). The total percentage of deaths occurring within a health facility is therefore $48,6 \%$. Nearly a third $(30,6 \%)$ of the deaths occurred at home while $2,4 \%$ were dead on arrival at a healthcare facility. This percentage distribution has remained largely the same over time.

Table 3.4: Number and percentage distribution of deaths by place of death occurrence, 2009

\begin{tabular}{|l|r|r|}
\hline Place of death & Number & Percentage \\
\hline Hospital & 255872 & 44,7 \\
\hline ER or Outpatient & 9678 & 1,7 \\
\hline Dead on arrival & 13650 & 2,4 \\
\hline Nursing home & 12691 & 2,2 \\
\hline Home & 175224 & 30,6 \\
\hline Other & 23478 & 4,1 \\
\hline Unknown or unspecified & 82080 & 14,3 \\
\hline Total & $\mathbf{5 7 2 6 7 3}$ & $\mathbf{1 0 0 , 0}$ \\
\hline
\end{tabular}

\subsection{Geographic variations in mortality}

This subsection provides information on the distribution of deaths by province of death occurrence, province of usual residence of the deceased as well as district municipalities of death occurrence for deaths that occurred in 2009. The information on geography was derived from place names, based on the 2011 municipal boundaries. The number and percentage distribution of deaths by province of death occurrence and province of usual residence of the deceased are provided in Appendix $\mathrm{G}$ and G.1, respectively. Appendix $\mathrm{H}$ provides the distribution of deaths at provincial and district municipality levels by age while the sex distribution is provided in Appendix I.

\subsubsection{Differences by province}

The distribution of deaths by province of death occurrence and province of usual residence of the deceased is presented in Table 3.5. It is important to note that the percentage distribution of deaths by province of occurrence is largely similar to the distribution of the South African population by province. However, the distribution of deaths by province of usual residence is affected by a large number of missing information, which when excluded, the distribution of deaths by province of usual residence of the deceased and province of death occurrence are similar. While province of death occurrence was unknown or unspecified in $0,2 \%$ of the deaths, province of usual residence of 
the deceased was unknown or unspecified in $10,0 \%$ of deaths while province of birth (results not shown) was unknown or unspecified in $21,8 \%$ of the deaths.

Table 3.5 shows that the highest number of deaths in 2009 occurred in KwaZulu-Natal, followed by Gauteng and Eastern Cape. Over 20\% of deaths occurred in KwaZulu-Natal (22,2\%) and Gauteng (20,0\%) while 14,3\% occurred in Eastern Cape. The lowest percentage of deaths occurred in Northern Cape $(2,6 \%)$ and less than $1 \%$ of deaths occurred outside South Africa. While the percentages for province of usual residence were not the same as those for province of death occurrence, the order of the percentages from highest to lowest remained the same for both.

The distribution of deaths by province of death occurrence and province of usual residence of the deceased shows that the majority of deaths in 2009 (at least $79 \%$ in each province) occurred within the province of usual residence (see Appendix G). Free State had the highest proportion (93,8\%) of the deceased dying within their province usual of residence while North West had the lowest at $79,2 \%$. Those who resided in North West but died elsewhere mainly died in Gauteng $(7,9 \%)$. Generally, most of those who did not die within their province of usual residence died in bordering provinces, particularly in Gauteng.

Subsequent analysis on geography focuses only on place of death occurrence; not on place of residence or place of birth of the deceased. The information on place of residence and place of birth of the deceased is available on request from Stats SA.

The age-sex distribution of deaths by province showed wide disparities by province (see Appendix $\mathrm{H}$ ). With regard to age, North West had the highest proportion of children dying in infancy $(9,4 \%)$ while Western Cape had the highest proportion of those dying at old ages (aged 65 and older). More than a third $(36,3 \%)$ of those who died in Western Cape were 65 years and older. Eastern Cape appeared to have the smallest proportion of children dying in infancy $(3,5 \%)$ - this may also indicate poor reporting of infant deaths in the province.

The results presented in Appendix G show that the sex ratio at death ranged from 97 male deaths per 100 female deaths in Limpopo to 120 male deaths per 100 female deaths in Western Cape. Limpopo was the only province where there were more females dying than males while in Eastern Cape there were nearly as many females as males dying.

Table 3.5: Distribution of deaths by province of death occurrence and province of usual residence of the deceased, 2009

\begin{tabular}{|l|r|r|r|r|}
\hline \multirow{2}{*}{ Province } & \multicolumn{2}{|c|}{ Province of death occurrence } & Province of usual residence of deceased \\
\cline { 2 - 4 } & Number & $\%$ & Number & $\%$ \\
\hline Western Cape & 45398 & 7,9 & 38428 & 6,7 \\
\hline Eastern Cape & 82132 & 14,3 & 70131 & 12,2 \\
\hline Northern Cape & 15082 & 2,6 & 14555 & 2,5 \\
\hline Free State & 47265 & 8,3 & 46264 & 8,1 \\
\hline KwaZulu-Natal & 127369 & 22,2 & 113593 & 19,8 \\
\hline North West & 40372 & 7,0 & 36639 & 6,4 \\
\hline Gauteng & 114729 & 20,0 & 101354 & 17,7 \\
\hline Mpumalanga & 45703 & 8,0 & 43692 & 7,6 \\
\hline Limpopo & 52907 & 9,2 & 49377 & 8,6 \\
\hline Foreign & 637 & 0,1 & 1283 & 0,2 \\
Unknown or unspecified & 1079 & 0,2 & 57357 & 10,0 \\
\hline Total & $\mathbf{5 7 2} \mathbf{6 7 3}$ & $\mathbf{1 0 0 , 0}$ & $\mathbf{5 7 2} \mathbf{6 7 3}$ & $\mathbf{1 0 0 , 0}$ \\
\hline
\end{tabular}




\subsubsection{Differences by district municipality of death occurrence}

The number of deaths by age and municipality of death occurrence is shown in Appendix $\mathrm{H}$. The results show that at least $10 \%$ of deaths occurred among infants in Dr Ruth Segomotsi Mompati in North West (10,5\%); John Taolo Gaetsewe in Northern Cape (10,2\%); and Ekurhuleni in Gauteng (10,0\%). District municipalities in Eastern Cape appear to have the lowest percentage of children who died within the year of birth, which as highlighted above may be a reflection of reporting.

The sex distribution of the deceased is provided in Appendix I. it is observed that all district municipalities in Western Cape, Northern Cape, North West, Gauteng and Mpumalanga had more male than female deaths as the sex ratios were all more than 100 in each of the district municipalities in these provinces. Some district municipalities in other provinces had more female than male deaths, particularly $n$ Eastern Cape, KwaZulu-Natal and Limpopo. For example, for 100 female deaths, there were 93 male deaths in Alfred Nzo (Eastern Cape); 96 male deaths in Sisonke (KwaZulu-Natal) and 90 male deaths in Greater Sekhukhune (Limpopo). 


\section{Causes of death}

\subsection{Introduction}

This section presents information on causes of death for all registered deaths that occurred in 2009 as well as some comparisons with data from 1997 to 2008, updated for late registrations. Information on causes of death is provided according to the 19 main groups (chapters) of the classification of death and an age breakdown of the proportion of deaths due to natural and non-natural causes. This is followed by an analysis of deaths due to natural causes that considers the leading underlying natural causes for broad groups of the classification of death, ranked as described in Section 2 of this release.

In view of the concern in South Africa about levels of violence and deaths due to accidents, non-natural underlying causes of death are treated as a separate group. Non-natural causes of death comprise all deaths that were not attributable, or may not have been attributable to natural causes. In terms of the Inquests Act (Act No. 58 of 1959), these deaths are subject to medico-legal investigation. An autopsy must be performed to establish the cause of death, and an inquest is compulsory. The results of the inquest are then sent to the Department of Home Affairs, which issues the final death certificate.

The last subsection provides a comparison between underlying, immediate and contributing causes of death. This analysis gives an overview of the recorded instances of multiple causes of death.

\subsection{Reported causes of death}

Information on diseases, injuries or complications that caused death is provided on the death notification form when a death is registered at the Department of Home Affairs (DHA). Provision is made for one or more causes to be recorded on the form in Part A and Part B (see copy of Form BI-1663 in Appendix B). Table 4.1 shows information on the number of causes of death reported on death notification forms for deaths that occurred in 2009. Only 275 forms (less than 1\%) had no cause of death recorded. These mainly include cases in which only the first page of the death notification form was received by Stats SA.

The majority of death notification forms $(59,0 \%)$ had only one cause recorded; just over a quarter $(26,9 \%)$ had two causes recorded; $10,3 \%$ had three causes recorded; and 3,8\% had four to six causes recorded. The pattern of recording causes on the death notification forms for 2009 is similar to that observed in the previous years.

The distribution of the number of causes of death recorded on death notification forms by province (results not shown) indicates that it is only in Western Cape where over half of the forms $(53,7 \%)$ had two or more causes. The provinces with the lowest proportions of recording two or more causes were Limpopo $(30,9 \%)$, Free State $(36,6 \%)$, North West (36,8\%) and Mpumalanga (38,9\%).

Table 4.1: Distribution of death notification forms by the number of causes entered on the form, 2009

\begin{tabular}{|l|r|r|}
\hline Number of reported causes of death & Number of death notification forms & Percentage \\
\hline No cause given & 275 & 0,0 \\
\hline One cause & 337774 & 59,0 \\
\hline Two causes & 153923 & 26,9 \\
\hline Three causes & 59188 & 10,3 \\
\hline Four causes & 17134 & 3,0 \\
\hline Five causes & 4356 & 0,8 \\
\hline Six causes & 23 & 0,0 \\
\hline Total & $\mathbf{5 7 2} \mathbf{6 7 3}$ & $\mathbf{1 0 0 , 0}$ \\
\hline
\end{tabular}




\subsection{Method of ascertaining the cause of death}

The death notification form makes provision for a certifying official to indicate the method that was used to ascertain the cause of death. Table 4.2 shows that in about half $(53,0 \%)$ of the deaths the causes of death were ascertained by opinions of medical personnel $(33,5 \%$ opinion of the attending medical practitioner, $17,3 \%$ opinion of attending medical practitioner on duty and $2,2 \%$ opinion of registered professional nurse). An interview with family members was used to certify the cause of death for $14,9 \%$ of the deaths while an autopsy was used in less than $10 \%(8,6 \%)$ of the deaths. Further analysis of the data (results not showed) indicated that those aged 5-14 had a higher proportion of causes of death ascertained through autopsy and the percentage was also higher among males as compared to females.

Table 4.2: Number and percentage distribution of deaths by method used to ascertain the cause of death, 2009

\begin{tabular}{|l|r|r|}
\hline Method of ascertaining cause of death & Number & Percentage \\
\hline Autopsy & 49141 & 8,6 \\
Opinion of attending medical practitioner & 191683 & 33,5 \\
Opinion of attending medical practitioner on duty & 99173 & 17,3 \\
Opinion of registered professional nurse & 12579 & 2,2 \\
Interview of family member & 85366 & 14,9 \\
Other & 12603 & 2,2 \\
Unspecified & 122128 & 21,3 \\
\hline Total & $\mathbf{5 7 2 6 7 3}$ & $\mathbf{1 0 0 , 0}$ \\
\hline
\end{tabular}

\subsection{Main groups of the underlying causes of death}

Figure 4.1 shows the percentage distribution of deaths by the 19 main groups (chapters) of the classification of causes of death. The top ranking main group of causes of death in 2009 (as has been the case in the previous years) was certain infections and parasitic diseases, comprising a quarter $(25,0 \%)$ of all deaths. This group also includes 1184 deaths due to multidrug-resistant tuberculosis (MDR-TB) and 151 deaths due to extensively drugresistant tuberculosis (XDR-TB). The reported number of deaths due to MDR-TB increased by $65,6 \%$ between 2008 and 2009 (from 715 deaths in 2008 to 1184 deaths in 2009) and XDR-TB increased by 11,0\% (from 136 deaths in 2008 to 151 deaths in 2009).

The second most common main group of causes of death was diseases of the circulatory system $(14,7 \%)$ followed by symptoms and signs not elsewhere classified (13,7\%), and diseases of the respiratory system (13,1\%). Less than $10 \%$ of the deaths were due to external causes of morbidity and mortality $(8,6 \%)$ and each of the other main groups. Neoplasms comprised $6,3 \%$ of all deaths, certain conditions originating in the perinatal period contributed $2,2 \%$ of all deaths, while pregnancy, childbirth and puerperium contributed $0,3 \%$ of all deaths.

The percentage distribution of deaths by selected main groups of causes of death (with at least $2 \%$ of deaths in 2009) for 2007-2009 is shown in Figure 4.2. It is observed that the proportion of deaths by main groups of causes of death has remained more or less the same during the period 2007-2009. Certain infectious and parasitic diseases were the most common causes of death for the three years and accounted for about a quarter of deaths for each year. Symptoms and signs not elsewhere classified, diseases of the circulatory and diseases of the respiratory system each contributed between $13 \%$ and $15 \%$ of the deaths for each year and for each cause.

The proportions of death due to neoplasms and diseases of the circulatory system increased slightly each year over the three-year period while those of diseases of the blood and immune mechanism decreased. For the rest of the main groups the proportions were either inconsistent over time or remained generally the same. 
Figure 4.1: Percentage distribution of deaths by main groups of causes of death, 2009

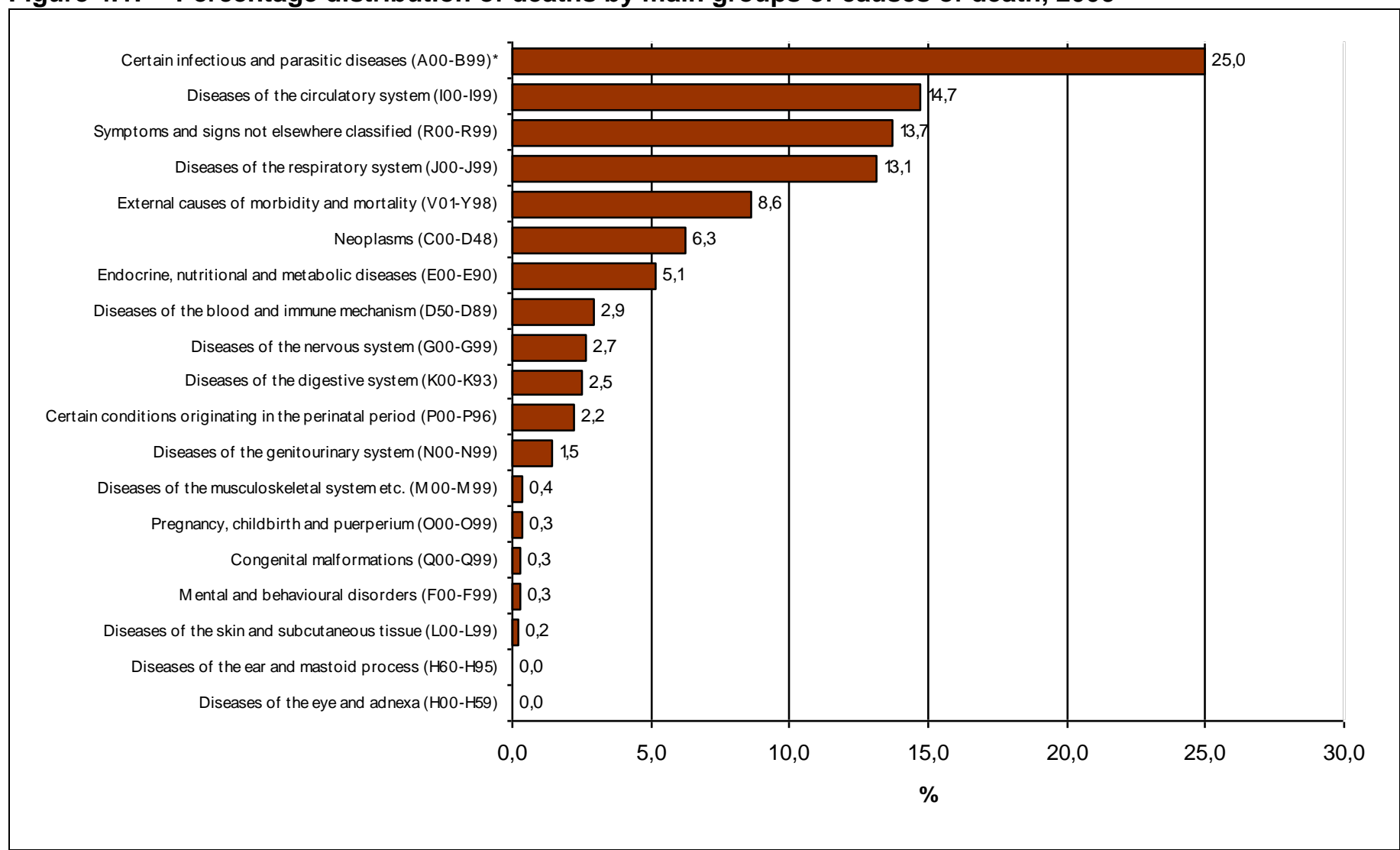

${ }^{\star}$ Including deaths due to MDR-TB and XDR-TB.

Figure 4.2: Percentage distribution of deaths by selected main groups of causes of death and year of death occurrence, 2007-2009*

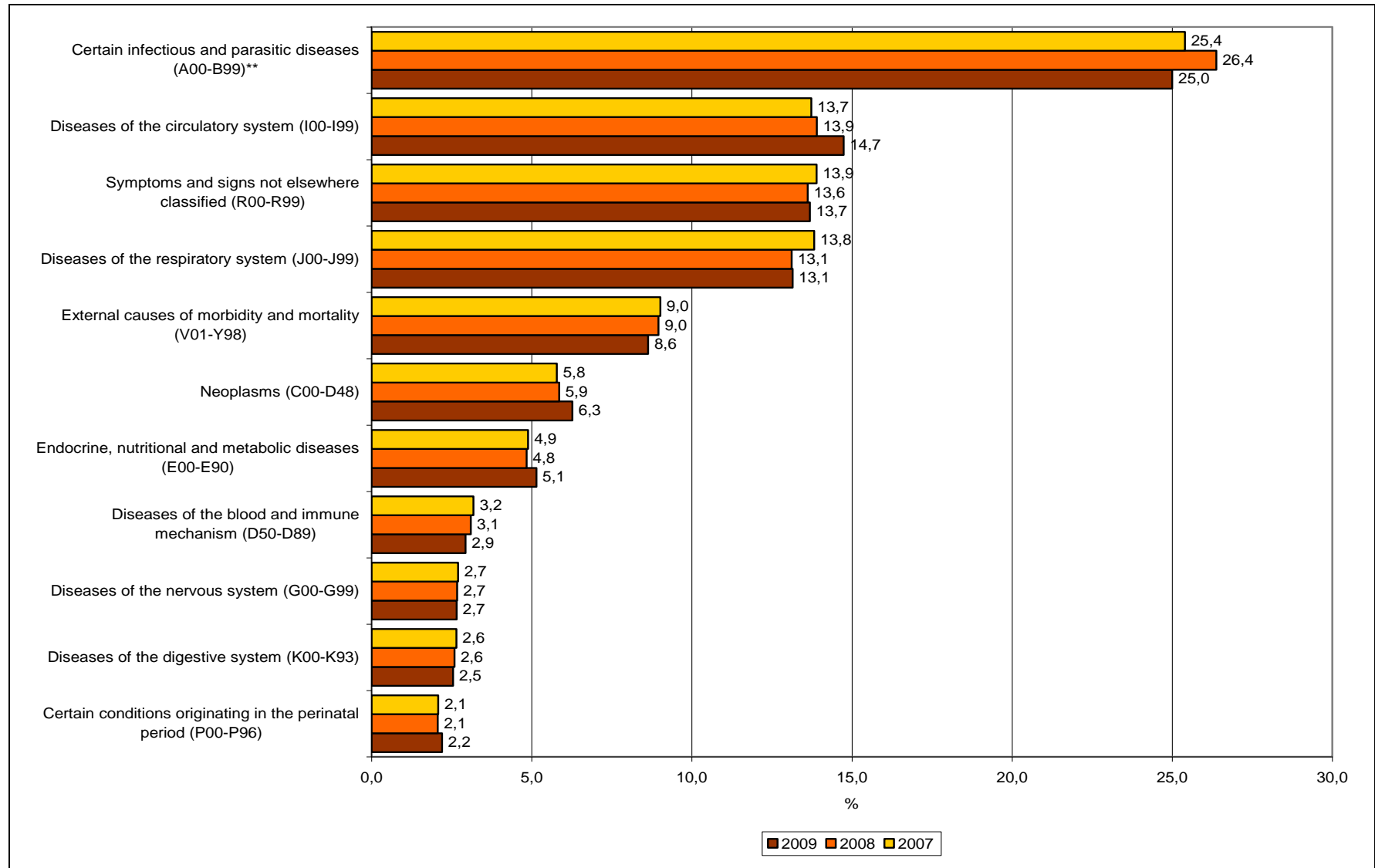

${ }^{*}$ Data for 2007 and 2008 have been updated to include late registrations processed in 2010/11.

** Including deaths due to MDR-TB and XDR-TB. 


\subsection{Natural and non-natural causes of death}

Table 4.3 and Figure 4.3 show the number and percentage of deaths due to natural and non-natural causes, respectively, from 1997 to 2009 . The number of natural deaths increased consistently from 263057 deaths in 1997 to 559812 deaths in 2006 after which the number decreased, reaching 523217 deaths in 2009. There was no consistent pattern with the number of non-natural deaths over the 13-year period, except for the period between 2001 and 2005 when deaths due to non-natural causes increased annually. There was a consistent decrease in the number of deaths due to non-natural causes from 2007.

The number of deaths due to natural causes decreased by 1,4\% between 2007 and 2008 and by $3,4 \%$ between 2008 and 2009. Similarly, the number of deaths due to non-natural causes decreased by $2,1 \%$ between 2007 and 2008 and by $7,2 \%$ between 2008 and 2009 .

Figure 4.3 shows that throughout the years, the majority of deaths (over $80 \%$ for all years) were due to natural causes. The percentage of deaths due to natural causes increased gradually from 1997 to 2006, after which it remained more or less constant at around $91 \%$ for two years before increasing again to $91,4 \%$ in 2009 . In 2009 , $91,4 \%$ of deaths were due to natural causes and $8,6 \%$ due to non-natural causes.

Table 4.3: Number of natural and non-natural deaths by year of death, 1997-2009*

\begin{tabular}{|l|r|r|r|}
\hline Year of death & Number of natural deaths & Number of non-natural deaths & Total \\
\hline 1997 & 263057 & 54094 & 317151 \\
\hline 1998 & 310760 & 55107 & 365867 \\
1999 & 328504 & 53335 & 381839 \\
\hline 2000 & 366536 & 49780 & 416316 \\
\hline 2001 & 404633 & 50338 & 454971 \\
\hline 2002 & 450670 & 51463 & 502133 \\
\hline 2003 & 504047 & 52835 & 556882 \\
\hline 2004 & 523456 & 53353 & 576809 \\
\hline 2005 & 544277 & 53963 & 53228 \\
\hline 2006 & 559812 & 54455 & 613040 \\
\hline 2007 & 549645 & 53300 & 604100 \\
\hline 2008 & 541852 & 49456 & 595152 \\
\hline 2009 & 523217 & & 572673 \\
\hline
\end{tabular}

*Data for 1997-2008 have been updated to include late registrations processed in 2010/11.

\section{Natural and non-natural causes of death by age}

Figure 4.4 shows the percentage distribution of deaths due to natural and non-natural causes classified by age group for deaths that occurred in 2009. The general pattern observed is that the proportion of deaths due to nonnatural causes increased almost consistently from age 0 to age group 15-19 and decreased thereafter. The age group that was mostly affected by non-natural causes was $15-19$, whereby $40,3 \%$ of the deaths were due to nonnatural causes. Other ages with higher proportions (over $20 \%$ ) of deaths due to non-natural causes were age groups 20-24 (32,0\%), 5-9 (25,2\%) and 10-14 (23,9\%). Ages least affected by non-natural deaths were infancy (less than 0 ) and older ages (60 years and older) where less than $5 \%$ of the deaths in each age group were due to non-natural causes of death.

The distribution by sex showed that of the male deaths that occurred in $2009,12,9 \%$ were due to non-natural causes while non-natural causes affected $4,1 \%$ of female deaths. 
Figure 4.3: Percentage distribution of natural and non-natural causes of death by year of death, 1997-2009*

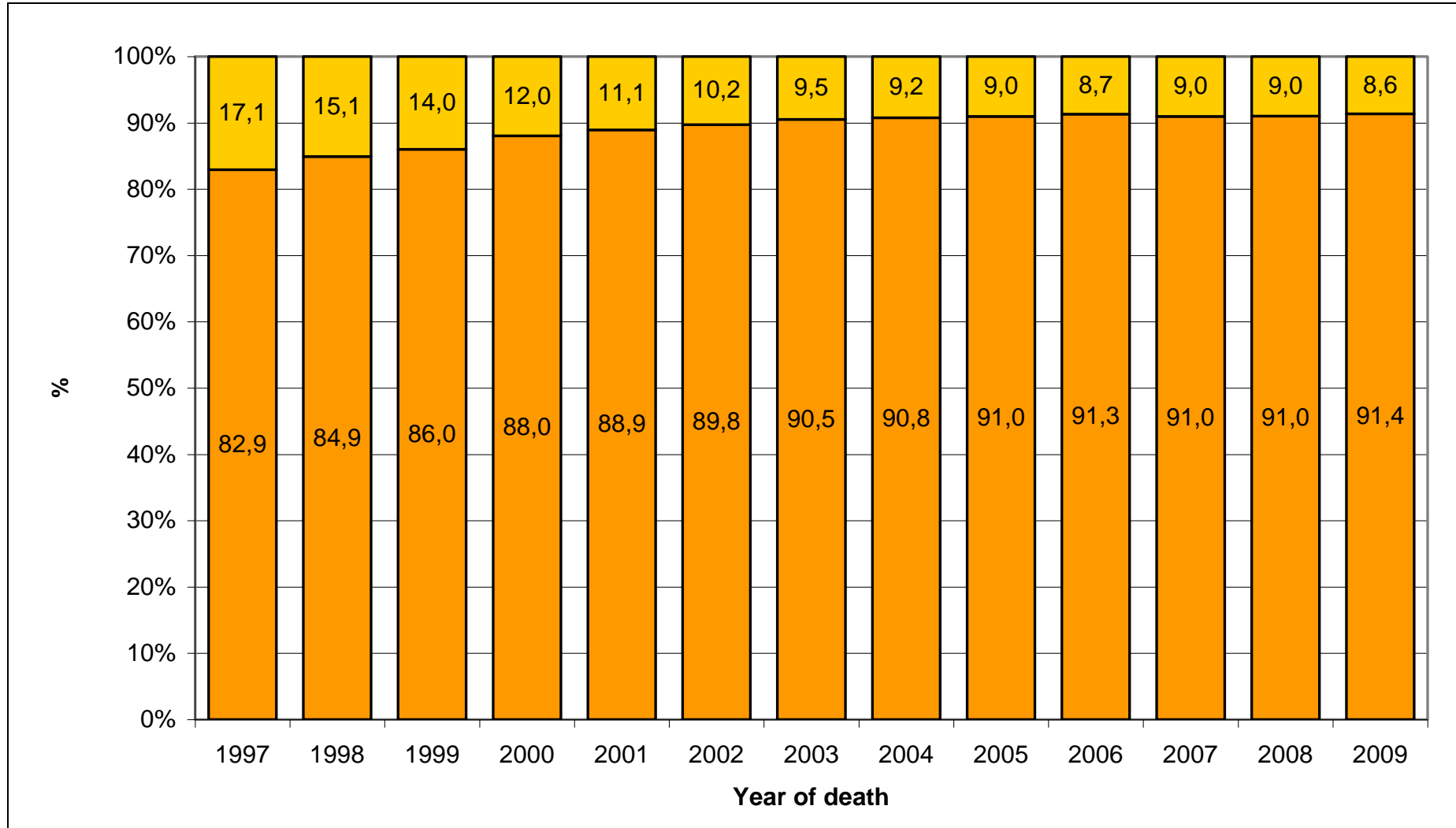

Data for 1997-2008 have been updated to include late registrations processed in 2010/11.

Figure 4.4: Percentage distribution of natural and non-natural causes of death by age, 2009*

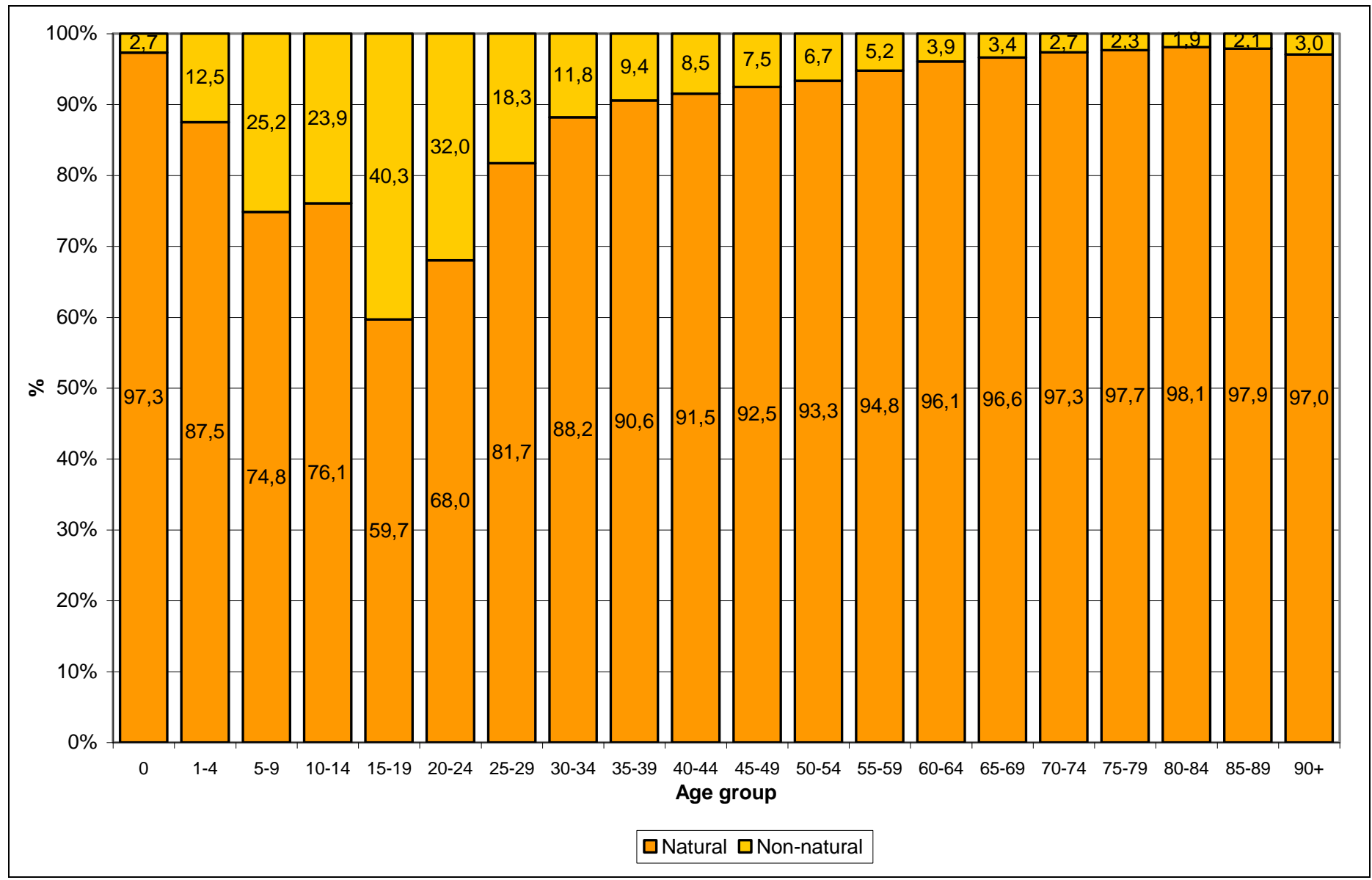




\subsection{Underlying natural causes of death}

This subsection presents information on the leading underlying natural causes of death. The ten leading causes are identified by ranking the causes of death by frequency among those eligible for ranking as described in Section 2. The top-ranking causes determine the leading underlying natural causes of death.

\section{Overall pattern of the leading underlying natural causes of death}

The ten leading underlying causes of death in South Africa in 2007-2009 are shown in Table 4.4. The distribution of deaths by all broad groups of causes of death ranked by frequency (including non-natural causes and symptoms and signs not elsewhere classified) for 2009 is shown in Appendix $\mathrm{J}$ while the breakdown of individual causes for the broad groups that were among the ten leading causes in 2009 is provided in Appendix K.

Table 4.4 shows that the ten leading natural underlying causes of death were the same for the three years, with the first six having the same rank order. Chronic lower respiratory diseases, certain disorders involving the immune mechanism, HIV disease and hypertensive diseases exchanged positions over the three years. For example, while chronic lower respiratory diseases were the seventh leading cause in 2007, it was the ninth in 2008 and 2009.

Tuberculosis was the leading cause of death during the three years, accounting for at least $12 \%$ of all deaths each year $(12,8 \%$ in $2007 ; 12,6 \%$ in 2008; and $12,0 \%$ in 2009). Influenza and pneumonia was the second leading underlying cause of death, followed by intestinal infectious diseases, other forms of heart disease, cerebrovascular diseases and diabetes mellitus. Human immunodeficiency virus (HIV) disease was the seventh leading cause of death in 2008 and 2009, accounting for $2,5 \%$ and 3,1\% of all deaths, respectively, having increased from the ninth leading cause in 2007. Certain disorders involving the immune mechanism was the eighth leading cause of death in 2007 and 2008, accounting for $2,5 \%$ of deaths in each year and the tenth leading cause in 2009 accounting for $2,3 \%$ of deaths.

A comparison of the absolute number of deaths for the ten leading underlying natural causes of death during 2007-2009 shows that the number of deaths due to tuberculosis, influenza and pneumonia, chronic lower respiratory diseases and certain disorders involving the immune mechanism consistently decreased over time while those due to other forms of heart disease, HIV disease and hypertensive diseases consistently increased. The pattern was not consistent for the others.

While the contribution of tuberculosis and influenza and pneumonia consistently decreased over time, it increased for other forms of heart disease, HIV disease and hypertensive diseases. On one hand, the number of deaths due to tuberculosis decreased by $2,4 \%$ between 2007 and 2008 and by $8,3 \%$ between 2008 and 2009 and those due to influenza and pneumonia decreased by $8,5 \%$ and 6,2\% between 2007 and 2008 and between 2008 and 2009, respectively. On the other hand, deaths due to HIV disease increased by $11,8 \%$ between 2007 and 2008 and by $15,8 \%$ between 2008 and 2009 while those due to hypertensive diseases increased by $6,0 \%$ and $8,1 \%$ between 2007 and 2008 and between 2008 and 2009, respectively. While there was no consistent pattern observed for deaths due to intestinal infectious diseases, they had the greatest decrease of 22,4\% between 2008 and 2009. 
Table 4.4: The ten leading underlying natural causes of death, 2007-2009*

\begin{tabular}{|c|c|c|c|c|c|c|c|c|c|}
\hline \multirow{2}{*}{$\begin{array}{l}\text { Causes of death (based on the } \\
10^{\text {th }} \text { revision, International } \\
\text { Classification of diseases, 1992) }\end{array}$} & \multicolumn{3}{|c|}{2009} & \multicolumn{3}{|c|}{2008} & \multicolumn{3}{|c|}{2007} \\
\hline & Rank & Number & $\%$ & Rank & Number & $\%$ & Rank & Number & $\%$ \\
\hline Tuberculosis (A15-A19) & 1 & 69003 & 12,0 & 1 & 75238 & 12,6 & 1 & 77091 & 12,8 \\
\hline Influenza and pneumonia (J09-J18) & 2 & 42964 & 7,5 & 2 & 45806 & 7,7 & 2 & 50035 & 8,3 \\
\hline $\begin{array}{l}\text { Intestinal infectious diseases (A00- } \\
\text { A09) }\end{array}$ & 3 & 30675 & 5,4 & 3 & 39512 & 6,6 & 3 & 37553 & 6,2 \\
\hline $\begin{array}{l}\text { Other forms of heart disease (I30- } \\
\text { I52) }\end{array}$ & 4 & 26462 & 4,6 & 4 & 26306 & 4,4 & 4 & 26144 & 4,3 \\
\hline Cerebrovascular diseases (I60-169) & 5 & 24835 & 4,3 & 5 & 24453 & 4,1 & 5 & 25438 & 4,2 \\
\hline Diabetes mellitus (E10-E14) & 6 & 20523 & 3,6 & 6 & 19622 & 3,3 & 6 & 20215 & 3,3 \\
\hline $\begin{array}{l}\text { Human immunodeficiency virus } \\
\text { [HIV] disease (B20-B24) }\end{array}$ & 7 & 17570 & 3,1 & 7 & 15172 & 2,5 & 9 & 13571 & 2,2 \\
\hline Hypertensive diseases (I10-I15) & 8 & 15386 & 2,7 & 10 & 14230 & 2,4 & 10 & 13429 & 2,2 \\
\hline $\begin{array}{l}\text { Chronic lower respiratory diseases } \\
(\mathrm{J} 40-\mathrm{J} 47)\end{array}$ & 9 & 14184 & 2,5 & 9 & 14322 & 2,4 & 7 & 15386 & 2,5 \\
\hline $\begin{array}{l}\text { Certain disorders involving the } \\
\text { immune mechanism (D80-D89) }\end{array}$ & 10 & 13096 & 2,3 & 8 & 14711 & 2,5 & 8 & 15349 & 2,5 \\
\hline Other natural causes & & 248519 & 43,4 & & 252480 & 42,4 & & 255434 & 42,3 \\
\hline Non-natural causes & & 49456 & 8,6 & & 53300 & 9,0 & & 54455 & 9,0 \\
\hline All causes & & 572673 & 100,0 & & 595152 & 100,0 & & 604100 & 100,0 \\
\hline
\end{tabular}

${ }^{*}$ Data for 2007-2008 have been updated to include late registrations processed in 2010/11.

** Including deaths due to MDR-TB and XDR-TB.

\section{Leading underlying natural causes of death by sex}

The distribution of the ten leading underlying natural causes of death by sex in 2009 is shown in Table 4.5. Overall, eight of the ten leading causes were the same for both sexes, although with different ranks beyond the fifth leading cause of death. On one hand, chronic lower respiratory diseases and ischaemic heart diseases were among the ten leading causes of death for males, but not for females. On the other hand, hypertensive diseases and other viral diseases were among the top ten underlying causes of death for females but not for males.

The five leading causes of death (tuberculosis, influenza and pneumonia, intestinal infectious diseases, other forms of heart disease and cerebrovascular diseases) were similar in rank for both sexes, representing over $30 \%$ of all deaths for each sex. While the ranks may be the same, the contribution of each cause to the total deaths differed for each sex. For example, although tuberculosis was the leading underlying cause of death for males and for females, it accounted for $13,0 \%$ of male deaths and $11,0 \%$ of female deaths.

Human immunodeficiency virus (HIV) disease was the sixth leading cause of death for males (accounting for 2,9\% of male deaths), but was the eighth leading cause of death among females (accounting for $3,3 \%$ of female deaths). Certain disorders involving the immune mechanism was the tenth and ninth leading cause of death for males $(2,1 \%)$ and females $(2,5 \%)$, respectively. Other viral diseases accounted for $2,3 \%$ of female deaths and was not among the ten leading causes of death for males. 
Table 4.5: The ten leading underlying natural causes of death for males and females, 2009*

\begin{tabular}{|c|c|c|c|c|c|c|}
\hline \multirow{2}{*}{$\begin{array}{l}\text { Causes of death (based on the 10th revision, International } \\
\text { Classification of Diseases, 1992) }\end{array}$} & \multicolumn{3}{|c|}{ Male } & \multicolumn{3}{|c|}{ Female } \\
\hline & Rank & Number & $\%$ & Rank & Number & $\%$ \\
\hline Tuberculosis $(\mathrm{A} 15-\mathrm{A} 19)^{\star *}$ & 1 & 38290 & 13,0 & 1 & 30628 & 11,0 \\
\hline Influenza and pneumonia (J09-J18) & 2 & 21269 & 7,2 & 2 & 21606 & 7,8 \\
\hline Intestinal infectious diseases (A00-A09) & 3 & 14338 & 4,9 & 3 & 16254 & 5,9 \\
\hline Other forms of heart disease (I30-I52) & 4 & 11895 & 4,0 & 4 & 14543 & 5,2 \\
\hline Cerebrovascular diseases (160-169) & 5 & 10395 & 3,5 & 5 & 14426 & 5,2 \\
\hline Human immunodeficiency virus [HIV] disease (B20-B24) & 6 & 8507 & 2,9 & 8 & 9034 & 3,3 \\
\hline Chronic lower respiratory diseases (J40-J47) & 7 & 8428 & 2,9 & $\ldots$ & $\ldots$ & $\ldots$ \\
\hline Diabetes mellitus (E10-E14) & 8 & 8183 & 2,8 & 6 & 12335 & 4,4 \\
\hline Ischaemic heart diseases (I20-I25) & 9 & 7259 & 2,5 & $\ldots$ & $\ldots$ & $\ldots$ \\
\hline Certain disorders involving the immune mechanism (D80-D89) & 10 & 6080 & 2,1 & 9 & 6996 & 2,5 \\
\hline Hypertensive diseases (I10-I15) & $\ldots$ & $\ldots$ & & 7 & 9471 & 3,4 \\
\hline Other viral diseases (B25-B34) & $\ldots$ & $\ldots$ & & 10 & 6375 & 2,3 \\
\hline Other natural causes & & 121454 & 41,3 & & 124497 & 44,9 \\
\hline Non-natural causes & & 38069 & 12,9 & & 11288 & 4,1 \\
\hline Total & & 294167 & 100,0 & & 277453 & 100,0 \\
\hline
\end{tabular}

The number of deaths associated with the ten leading causes of death classified by sex for the period 2007-2009 is shown in Figure 4.5. Over the three year period, tuberculosis remained the leading cause of death for both males and females, followed by influenza and pneumonia and then intestinal infectious diseases.

The main similarity between males and females is that there were year-by-year increases in the number of deaths due to HIV disease and hypertensive diseases for both sexes and decreases in the number of deaths due to tuberculosis, certain disorders involving the immune mechanism, influenza and pneumonia and chronic lower respiratory infections for both sexes.

For both sexes, the greatest decrease between 2008 and 2009 was observed in the number of deaths due to intestinal infectious diseases $(21,5 \%$ for males and $23,2 \%$ for females) and the greatest increase in the number of deaths due to HIV disease (17,4\% for males and $14,3 \%$ for females). There were no marked differences in the number of deaths due to cerebrovascular diseases, other forms of heart diseases and ischaemic heart diseases over the three-year period for both sexes.

Further comparison between males and females shows that female deaths exceeded male deaths in all specified causes with the exception of tuberculosis, ischaemic heart diseases and chronic lower respiratory infections. 
Figure 4.5: Distribution of deaths for the leading causes of death by year of death and sex, 2007-2009*

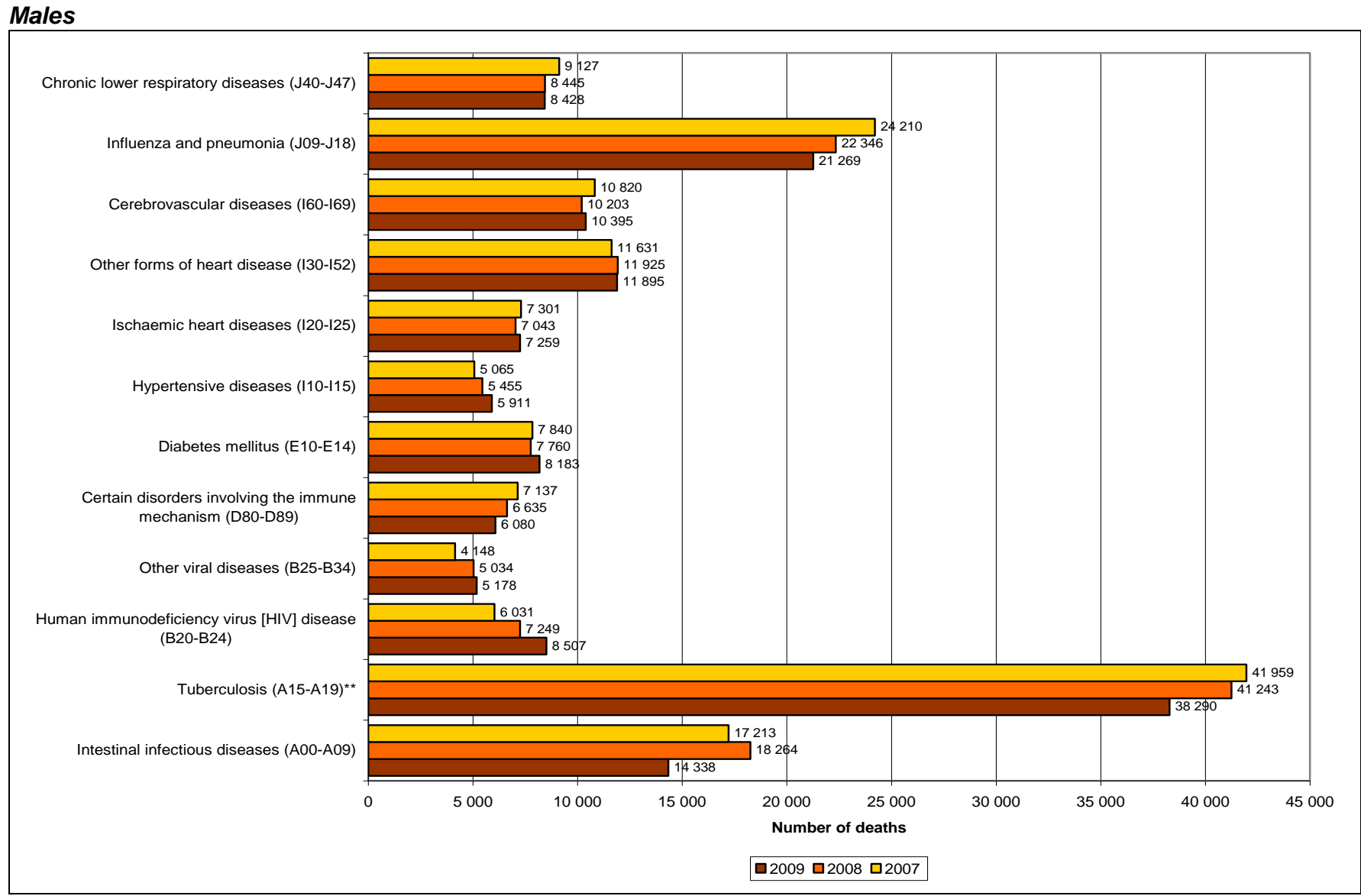

\section{Females}

Chronic lower respiratory diseases (J40-J47)

Influenza and pneumonia (J09-J18)

Cerebrovascular diseases (160-169)

Other forms of heart disease (130-152)

Ischaemic heart diseases (120-125)

Hypertensive diseases (110-115)

Diabetes mellitus (E10-E14)

Certain disorders involving the immun mechanism (D80-D89)

Other viral diseases (B25-B34)

Human immunodeficiency virus [HIV] diseas (B20-B24)

Tuberculosis (A15-A19)

Intestinal infectious diseases (A00-A09)
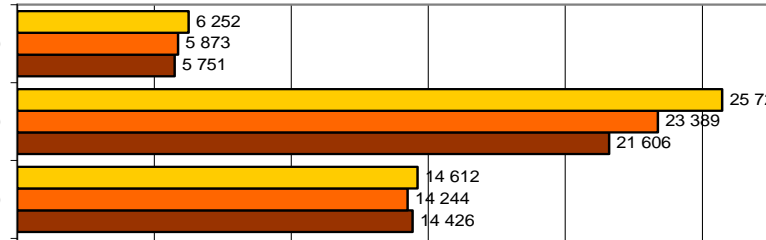

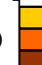

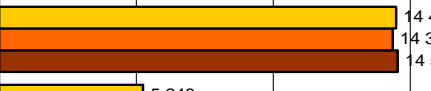

426

\section{9}

563
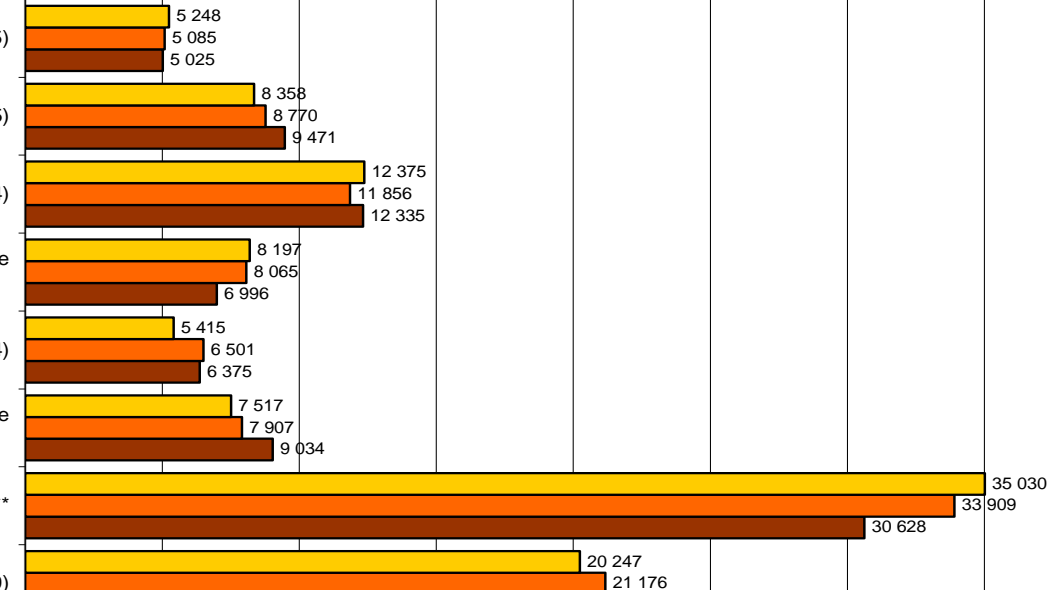

西

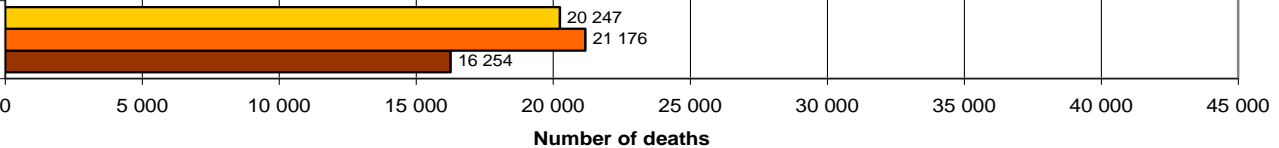

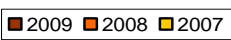

${ }^{*}$ Data for 2007-2008 have been updated to include late registrations processed in 2010/11.

** Including deaths due to MDR-TB and XDR-TB. 


\section{Leading underlying natural causes of death by age}

The ten leading causes of death classified by broad age groups $0-14,15-49,50-64$, and 65 years and older for 2009 are given in Table 4.6. It is observed that three underlying natural causes of death (intestinal infectious diseases, influenza and pneumonia and tuberculosis) were common for all these age groups. However, the ranks of these causes and their individual contribution to the total number of deaths differed widely by age. For example, tuberculosis was the leading underlying natural cause of death for those aged 15-49 and 50-64 (contributing $19,6 \%$ and $11,4 \%$ of deaths in each of these age groups, respectively) but was the fifth leading cause of death for those aged $0-14$ (contributing 3,4\% of deaths in this age group) and the eighth leading cause of death for those aged 65 year and older (contributing 3,3\%). The leading underlying natural cause of death for those aged 0-14 was intestinal infectious disease and cerebrovascular diseases were leading among those who were aged 65 years and older at the time of their death.

For those aged 0-14 years, intestinal infectious diseases and influenza and pneumonia contributed over a quarter of deaths $(28,1 \%)$ in this age group. Malnutrition was the fourth leading cause of death, contributing $3,5 \%$ of deaths in this age group and HIV disease the tenth, contributing 1,7\%. Amongst those aged 15-49 tuberculosis (19,6\%) was the leading cause of death, followed by influenza and pneumonia $(8,6 \%)$ and HIV disease $(5,5 \%)$. HIV disease appeared among the ten leading causes of death in age groups $0-14$ and $15-49$ only.

The ten leading causes of death for those aged 50-64 and 65 years were the same, with differences in rank and the contribution of each cause to the overall number of deaths in each age group. While cerebrovascular diseases were the leading cause of death among those aged 65 and older, contributing $9,8 \%$ of deaths in this age group, it was the fourth leading cause of death among those aged $50-64$, accounting for $5,6 \%$ of deaths.

Four diseases of the circulatory system (other forms of heart disease, cerebrovascular diseases, ischaemic heart diseases and hypertensive diseases) were among the ten leading causes of death for those aged 50-64 and 65 years and older, contributing a total of $18,3 \%$ and $29,8 \%$ of deaths in each age group, respectively. Malignant neoplasm of digestive organs was the only neoplasm appearing among the leading causes of death in ages 50-64 and 65 years and older and contributed $3,0 \%$ of deaths in each age group.

\section{Leading underlying natural causes of death for infants and children}

Table 4.7 shows the ten leading causes of death for neonatal deaths (for babies aged less than 29 days), postneonatal deaths (29 days to 11 months), all infant deaths (aged less than one year), and deaths among those aged 1-4 years. Infant deaths are composed of both neonatal and post-neonatal deaths.

It is observed that there were no overlapping leading underlying causes of death for those who died during the neonatal and postneonatal period. Neonatal deaths mainly resulted from conditions originating in the perinatal period and congenital malformations, deformations and chromosomal abnormalities were among the ten leading causes). The leading cause of death for neonatal deaths in 2009 was respiratory and cardiovascular disorders specific to the perinatal period, accounting for $42,0 \%$ of all neonatal deaths. This was followed by disorders related to length of gestation and foetal growth $(11,9 \%)$, other disorders originating in the perinatal period $(11,2 \%)$ and infections specific to the perinatal period $(10,1 \%)$. Congenital malformations appearing in the ten leading natural causes of neonatal deaths contributed a total of $4,0 \%$ of the deaths during the neonatal period.

The leading cause of death for those who died during the postneonatal period was intestinal infectious diseases $(26,8 \%)$ followed by influenza and pneumonia (17,9\%). These two causes contributed $44,7 \%$ of deaths during this period. Malnutrition $(4,2 \%)$ was the third leading cause of death, tuberculosis $(2,2 \%)$ the sixth and HIV disease $(2,0 \%)$ the eighth.

For overall infant deaths, the leading cause of death was intestinal infectious diseases $(17,4 \%)$, followed by respiratory and cardiovascular disorders specific to the perinatal period $(15,2 \%)$ and influenza and pneumonia $(11,7 \%)$. These three causes accounted for $44,2 \%$ of all infant deaths. The three leading causes of death for those aged 1-4 years were intestinal infectious diseases (21,6\%), influenza and pneumonia (12,0\%) and malnutrition $(7,6 \%)$. Tuberculosis $(5,2 \%)$ was the fourth leading cause of death while HIV disease $(2,2 \%)$ was the fifth and certain disorders involving the immune mechanism $(2,1 \%)$ were the sixth.

Five underlying natural causes of death that were common for infants and children (aged 1-4 years) were: intestinal infectious diseases, influenza and pneumonia, malnutrition and other acute lower respiratory infections. Intestinal infectious diseases were the leading cause for both ages and contributed $17,4 \%$ of infant deaths and $21,6 \%$ of those aged $1-4$ years. 
Table 4.6: The ten leading underlying natural causes of death for broad age groups, 2009

\begin{tabular}{|c|c|c|c|c|c|c|c|c|c|c|c|c|}
\hline \multirow{2}{*}{$\begin{array}{l}\text { Causes of death (based on the } 10^{\text {th }} \text { Revision, International Classification of } \\
\text { Diseases, 1992) }\end{array}$} & \multicolumn{3}{|c|}{$0-14$} & \multicolumn{3}{|c|}{$15-49$} & \multicolumn{3}{|c|}{$50-64$} & \multicolumn{3}{|c|}{$65+$} \\
\hline & Rank & Number & $\%$ & Rank & Number & $\%$ & Rank & Number & $\%$ & Rank & Number & $\%$ \\
\hline Intestinal infectious diseases (A00-A09) & 1 & 9972 & 16,9 & 4 & 13075 & 5,2 & 9 & 3493 & 3,2 & 10 & 4092 & 2,7 \\
\hline Influenza and pneumonia (J09-J18) & 2 & 6666 & 11,3 & 2 & 21587 & 8,6 & 3 & 6580 & 6,1 & 5 & 8035 & 5,3 \\
\hline Respiratory and cardiovascular disorders specific to the perinatal period (P20-P29) & 3 & 5759 & 9,7 & $\ldots$ & $\ldots$ & $\ldots$ & $\ldots$ & $\ldots$ & $\ldots$ & & & \\
\hline Malnutrition (E40-E46) & 4 & 2042 & 3,5 & $\ldots$ & $\ldots$ & $\ldots$ & $\ldots$ & $\ldots$ & $\ldots$ & & & \\
\hline Tuberculosis $(\mathrm{A} 15-\mathrm{A} 19)^{*}$ & 5 & 2032 & 3,4 & 1 & 49403 & 19,6 & 1 & 12221 & 11,4 & 8 & 5092 & 3,3 \\
\hline Disorders related to length of gestation and fetal growth (P05-P08) & 6 & 1719 & 2,9 & $\ldots$ & $\ldots$ & $\ldots$ & $\ldots$ & $\ldots$ & $\ldots$ & & & \\
\hline Other disorders originating in the perinatal period (P90-P96) & 7 & 1563 & 2,6 & $\ldots$ & & $\ldots$ & $\ldots$ & $\ldots$ & $\ldots$ & & & \\
\hline Infections specific to the perinatal period (P35-P39) & 8 & 1409 & 2,4 & $\ldots$ & & $\ldots$ & $\ldots$ & & $\ldots$ & & & \\
\hline Other acute lower respiratory infections (J20-J22) & 9 & 1022 & 1,7 & 9 & 4050 & 1,6 & $\ldots$ & & $\ldots$ & & & \\
\hline Human immunodeficiency virus [HIV] disease (B20-B24) & 10 & 1011 & 1,7 & 3 & 13953 & 5,5 & $\ldots$ & & $\ldots$ & & & \\
\hline Certain disorders involving the immune mechanism (D80-D89) & $\ldots$ & $\ldots$ & & 5 & 9865 & 3,9 & $\ldots$ & & $\ldots$ & & & \\
\hline Other viral diseases (B25-B34) & $\ldots$ & $\ldots$ & & 6 & 8946 & 3,6 & $\ldots$ & & $\ldots$ & & & \\
\hline Other forms of heart disease (130-152) & $\ldots$ & $\ldots$ & & 7 & 5956 & 2,4 & 5 & 5951 & 5,5 & 2 & 13906 & 9,1 \\
\hline Inflammatory diseases of the central nervous system (G00-G09) & $\ldots$ & $\ldots$ & & 8 & 5725 & 2,3 & $\ldots$ & & $\ldots$ & & & \\
\hline Cerebrovascular diseases (160-169) & $\ldots$ & $\ldots$ & & 10 & 3631 & 1,4 & 4 & 6064 & 5,6 & 1 & 15039 & 9,8 \\
\hline Diabetes mellitus (E10-E14) & $\ldots$ & $\ldots$ & & & & .. & 2 & 6813 & 6,3 & 3 & 10909 & 7,1 \\
\hline Chronic lower respiratory diseases (J40-J47) & $\ldots$ & $\ldots$ & & & & $\ldots$ & 6 & 4282 & 4,0 & 7 & 6793 & 4,4 \\
\hline Hypertensive diseases (I10-I15) & $\ldots$ & $\ldots$ & & & & $\ldots$ & 7 & 4148 & 3,9 & 4 & 9379 & 6,1 \\
\hline Ischaemic heart diseases (I20-I25) & $\ldots$ & $\ldots$ & & & & . & 8 & 3499 & 3,3 & 6 & 7200 & 4,7 \\
\hline Malignant neoplasm of digestive organs (C15-C26) & $\ldots$ & $\ldots$ & & & & & 10 & 3269 & 3,0 & 9 & 4615 & 3,0 \\
\hline Other natural causes & & 21266 & 35,9 & & 80832 & 32,1 & & 45490 & 42,3 & & 63969 & 41,8 \\
\hline Non-natural causes & & 4720 & 8,0 & & 34632 & 13,8 & & 5745 & 5,3 & & 3964 & 2,6 \\
\hline All causes & & 59181 & 100,0 & & 251655 & 100,0 & & 107555 & 100,0 & & 152993 & 100,0 \\
\hline
\end{tabular}

*Including deaths due to MDR-TB and XDR-TB

.. Category not in top ten 
Table 4.7: The ten leading underlying natural causes of death for infants and children, 2009

\begin{tabular}{|c|c|c|c|c|c|c|c|c|c|c|c|c|}
\hline \multirow{2}{*}{$\begin{array}{l}\text { Causes of death (based on the } 10^{\text {th }} \text { Revision, International Classification of } \\
\text { Diseases, 1992) }\end{array}$} & \multicolumn{3}{|c|}{ Neonatal } & \multicolumn{3}{|c|}{ Post-neonatal } & \multicolumn{3}{|c|}{ Less than 1 year } & \multicolumn{3}{|c|}{$1-4$ years } \\
\hline & Rank & Number & $\%$ & Rank & Number & $\%$ & Rank & Number & $\%$ & Rank & Number & $\%$ \\
\hline Respiratory and cardiovascular disorders specific to the perinatal period (P20-P29) & 1 & 5648 & 42,0 & $\ldots$ & & $\ldots$ & 2 & 5754 & 15,2 & $\ldots$ & $\ldots$ & \\
\hline Disorders related to length of gestation and fetal growth (P05-P08) & 2 & 1594 & 11,9 & $\ldots$ & $\ldots$ & $\ldots$ & 4 & 1703 & 4,5 & $\ldots$ & $\ldots$ & $\ldots$ \\
\hline Other disorders originating in the perinatal period (P90-P96) & 3 & 1508 & 11,2 & $\cdots$ & & $\ldots$ & 5 & 1556 & 4,1 & $\cdots$ & $\ldots$ & \\
\hline Infections specific to the perinatal period (P35-P39) & 4 & 1353 & 10,1 & $\ldots$ & $\ldots$ & $\ldots$ & 6 & 1406 & 3,7 & $\ldots$ & $\ldots$ & $\cdots$ \\
\hline $\begin{array}{l}\text { Fetus and newborn affected by maternal factors and by complications of } \\
\text { pregnancy, labour and delivery (P00-P04) }\end{array}$ & 5 & 964 & 7,2 & $\ldots$ & $\ldots$ & $\ldots$ & 8 & 972 & 2,6 & $\ldots$ & $\ldots$ & \\
\hline Digestive system disorders of fetus and newborn (P75-P78) & 6 & 490 & 3,6 & $\ldots$ & $\ldots$ & $\ldots$ & $\ldots$ & $\ldots$ & $\ldots$ & $\ldots$ & $\ldots$ & $\ldots$ \\
\hline Haemorrhagic and haematological disorders of fetus and newborn (P50-P61) & 7 & 349 & 2,6 & $\ldots$ & & $\ldots$ & $\ldots$ & $\ldots$ & $\ldots$ & $\ldots$ & $\ldots$ & \\
\hline Other congenital malformations (Q80-Q89) & 8 & 268 & 2,0 & $\ldots$ & $\ldots$ & $\ldots$ & $\ldots$ & $\ldots$ & $\ldots$ & $\ldots$ & $\ldots$ & .. \\
\hline Congenital malformations of the circulatory system (Q20-Q28) & 9 & 155 & 1,2 & $\ldots$ & $\ldots$ & $\ldots$ & $\ldots$ & $\ldots$ & $\ldots$ & $\ldots$ & $\ldots$ & $\ldots$ \\
\hline Congenital malformations of the nervous system (Q00-Q07) & 10 & 109 & 0,8 & ... & & $\ldots$ & $\ldots$ & $\ldots$ & . & $\ldots$ & $\ldots$ & \\
\hline Intestinal infectious diseases (A00-A09) & $\ldots$ & $\ldots$ & $\ldots$ & 1 & 6574 & 26,8 & 1 & 6608 & 17,4 & 1 & 2702 & 21,6 \\
\hline Malnutrition (E40-E46) & $\ldots$ & $\ldots$ & $\ldots$ & 3 & 1032 & 4,2 & 7 & 1045 & 2,8 & 3 & 950 & 7,6 \\
\hline Other acute lower respiratory infections (J20-J22) & ... & ... & $\ldots$ & 4 & 664 & 2,7 & 9 & 687 & 1,8 & 7 & 226 & 1,8 \\
\hline Other bacterial diseases (A30-A49) & $\ldots$ & $\ldots$ & $\ldots$ & 5 & 545 & 2,2 & 10 & 551 & 1,5 & $\ldots$ & $\ldots$ & $\cdots$ \\
\hline Tuberculosis (A15-A19) & $\ldots$ & $\ldots$ & $\ldots$ & 6 & 542 & 2,2 & $\ldots$ & $\ldots$ & $\ldots$ & 4 & 647 & 5,2 \\
\hline Protozoal diseases (B50-B64) & . & $\ldots$ & $\ldots$ & 7 & 501 & 2,0 & $\ldots$ & $\ldots$ & $\ldots$ & $\ldots$ & $\ldots$ & \\
\hline Human immunodeficiency virus [HIV] disease (B20-B24) & $\ldots$ & $\ldots$ & $\ldots$ & 8 & 486 & 2,0 & $\ldots$ & $\ldots$ & $\ldots$ & 5 & 279 & 2,2 \\
\hline Certain disorders involving the immune mechanism (D80-D89) & $\ldots$ & $\ldots$ & $\ldots$ & 9 & 453 & 1,8 & $\ldots$ & $\ldots$ & $\ldots$ & 6 & 259 & 2,1 \\
\hline Other viral diseases (B25-B34) & $\ldots$ & $\ldots$ & $\ldots$ & 10 & 407 & 1,7 & $\ldots$ & $\ldots$ & $\ldots$ & 9 & 200 & 1,6 \\
\hline Inflammatory diseases of the central nervous system (G00-G09) & & & & & & $\ldots$ & $\ldots$ & $\ldots$ & & 8 & 216 & 1,7 \\
\hline Other forms of heart disease (130-152) & $\ldots$ & $\ldots$ & $\ldots$ & $\ldots$ & $\ldots$ & $\ldots$ & $\ldots$ & $\ldots$ & $\ldots$ & 10 & 184 & 1,5 \\
\hline Other natural causes & & 865 & 6,4 & & 8052 & 32,8 & & 12239 & 32,2 & & 3775 & 30,2 \\
\hline Non-natural & & 140 & 1,0 & & 883 & 3,6 & & 1023 & 2,7 & & 1559 & 12,5 \\
\hline All causes & & 13443 & 100,0 & & 24531 & 100,0 & & 37974 & 100,0 & & 12497 & 100,0 \\
\hline
\end{tabular}

*Including deaths due to $M D R-T B$ and $X D R-T B$

Category not in top ten 


\section{Leading underlying natural causes of death for the population aged 15-24}

The World Health Organization suggested in the ICD-10 recommendations that the 15-24 age group must also be included in the analysis for international comparison (WHO, 1992). This analysis is provided in Table 4.8. Tuberculosis was the leading cause of death for those aged 15-24, accounting for $14,1 \%$ of deaths in this age group, followed by influenza and pneumonia $(6,3 \%)$ and intestinal infectious diseases $(3,9 \%)$. HIV disease, other viral diseases and certain disorders involving the immune mechanism were the fourth, fifth and sixth leading causes of death, respectively. The ten leading causes of death in 2009 were the same as those observed in 2008 , although some causes changed ranks.

Table 4.8: The ten leading underlying natural causes of death for the population aged 15-24 years, 2009

\begin{tabular}{|l|r|r|r|}
\hline \multirow{2}{*}{$\begin{array}{l}\text { Causes of death (based on the } \mathbf{1 0}^{\text {th }} \text { Revision, International Classification } \\
\text { of Diseases, 1992) }\end{array}$} & Rank & Number & 15-24 years \\
\hline Tuberculosis (A15-A19) & 1 & 4244 & 14,1 \\
\hline Influenza and pneumonia (J09-J18) & 2 & 1887 & 6,3 \\
\hline Intestinal infectious diseases (A00-A09) & 3 & 1170 & 3,9 \\
\hline Human immunodeficiency virus [HIV] disease (B20-B24) & 5 & 801 & 3,5 \\
\hline Other viral diseases (B25-B34) & 6 & 759 & 2,7 \\
\hline Certain disorders involving the immune mechanism (D80-D89) & 7 & 706 & 2,5 \\
\hline Inflammatory diseases of the central nervous system (G00-G09) & 8 & 624 & 2,3 \\
\hline Other forms of heart disease (I30-I52) & 9 & 351 & 1,2 \\
\hline Episodic and paroxysmal disorders (G40-G47) & 10 & 330 & 1,1 \\
\hline Other acute lower respiratory infections (J20-J22) & & 7828 & 26,0 \\
\hline Other natural causes & & 10362 & 34,4 \\
\hline Non-natural causes & & $\mathbf{3 0} 131$ & $\mathbf{1 0 0 , 0}$ \\
\hline Total & & & \\
\hline
\end{tabular}

${ }^{*}$ Including deaths due to $M D R-T B$ and $X D R-T B$

\section{Leading underlying natural causes of death by province of death occurrence}

Table 4.9 shows the provincial differences in the ranking of the ten leading underlying causes of death for 2009. Detailed information on the distribution of the ten leading underlying causes by province, age and sex is provided in Appendices L to L.9.

Tuberculosis was the leading cause of death in all provinces except Free State and Limpopo where it ranked second. In these two provinces, influenza and pneumonia was the leading cause of death. Although tuberculosis ranked first in seven provinces, its contribution differed by province. The highest proportion of deaths due to tuberculosis was observed in KwaZulu-Natal (16,2\%) followed by Eastern Cape (13,6\%), Mpumalanga (13,4\%)and North West $(12,3 \%)$. The proportion of deaths due to tuberculosis in these provinces were all higher than the national average of $12,0 \%$ in 2009. The lowest proportion of deaths due to tuberculosis was observed in Limpopo and Western Cape, contributing $8,9 \%$ of deaths in each province.

The causes of death that were common for all the nine provinces were tuberculosis, diabetes mellitus, cerebrovascular diseases, hypertensive diseases and other forms of heart disease. However, the ranks of these causes differed between provinces. For example, while diabetes mellitus was the second leading cause of death in Western Cape $(6,2 \%)$, it was the eighth leading cause of death in Northern Cape $(3,0 \%)$, Free State $(2,7 \%)$ and North West $(2,6 \%)$.

HIV disease was among the ten leading causes of death in all provinces except Free State and Limpopo. It was the second leading cause of death in Northern Cape, accounting for 5,9\% of deaths in the province and fourth in Western Cape, accounting for $5,2 \%$ of all deaths in this province. Influenza and pneumonia and intestinal infectious diseases were among the ten leading causes of death in all provinces, with the exception of Western Cape.

Malignant neoplasms of digestive organs and malignant neoplasms of respiratory and intrathoracic organs were among the ten leading causes of death only in Western Cape while inflammatory diseases of the central nervous system were among the ten leading causes of death only in Limpopo. 


\section{Table 4.9: The ten leading underlying natural causes of death in each province of death occurrence, 2009}

\begin{tabular}{|c|c|c|c|c|c|c|c|c|c|c|c|c|c|c|c|c|c|c|c|c|c|c|c|c|c|c|c|}
\hline \multirow{2}{*}{$\begin{array}{l}\text { Causes of death (based on } \\
\text { the } 10^{1 \text { th }} \text { Revision, } \\
\text { International Classification } \\
\text { of Diseases, 1992) }\end{array}$} & \multicolumn{3}{|c|}{ Western Cape } & \multicolumn{3}{|c|}{ Eastern Cape } & \multicolumn{3}{|c|}{ Northern Cape } & \multicolumn{3}{|c|}{ Free State } & \multicolumn{3}{|c|}{ KwaZulu-Natal } & \multicolumn{3}{|c|}{ North West } & \multicolumn{3}{|c|}{ Gauteng } & \multicolumn{3}{|c|}{ Mpumalanga } & \multicolumn{3}{|c|}{ Limpopo } \\
\hline & $* \star$ & No. & $\%$ & $* \star$ & No. & $\%$ & ** & No. & $\%$ & ** & No. & $\%$ & ** & No. & $\%$ & ** & No. & $\%$ & ** & No. & $\%$ & $* *$ & No. & $\%$ & ** & No. & $\%$ \\
\hline Tuberculosis (A15-A19) & 1 & 4041 & 8,9 & 1 & 11132 & 13,6 & 1 & 1465 & 9,7 & 2 & 5179 & 11,0 & 1 & 20618 & 16,2 & 1 & 4982 & 12,3 & 1 & 10595 & 9,2 & 1 & 6137 & 13,4 & 2 & 4696 & 8,9 \\
\hline Diabetes mellitus (E10-E14) & 2 & 2824 & 6,2 & 7 & 2773 & 3,4 & 8 & 449 & 3,0 & 8 & 1262 & 2,7 & 6 & 4901 & 3,8 & 8 & 1063 & 2,6 & 6 & 3689 & 3,2 & 7 & 1593 & 3,5 & 6 & 1924 & 3,6 \\
\hline $\begin{array}{l}\text { Ischaemic heart diseases } \\
\text { (120-125) }\end{array}$ & 3 & 2775 & 6,1 & $\cdots$ & $\cdots$ & $\cdots$ & $\cdots$ & $\cdots$ & $\cdots$ & 10 & 812 & 1,7 & & & 0,0 & $\cdots$ & $\cdots$ & $\cdots$ & 8 & 2905 & 2,5 & & & 0,0 & $\cdots$ & $\cdots$ & $\cdots$ \\
\hline HIV disease (B20-B24) & 4 & 2347 & 5,2 & 8 & 2349 & 2,9 & 2 & 883 & 5,9 & $\ldots$ & $\ldots$ & $\ldots$ & 7 & 4743 & 3,7 & 9 & 980 & 2,4 & 7 & 3223 & 2,8 & 6 & 1752 & 3,8 & $\ldots$ & $\ldots$ & $\ldots$ \\
\hline $\begin{array}{l}\text { Cerebrovascular diseases } \\
(160-169)\end{array}$ & 5 & 2274 & 5,0 & 5 & 3315 & 4,0 & 4 & 632 & 4,2 & 6 & 1787 & 3,8 & 4 & 6257 & 4,9 & 5 & 1572 & 3,9 & 5 & 4382 & 3,8 & 4 & 2151 & 4,7 & 5 & 2397 & 4,5 \\
\hline $\begin{array}{l}\text { Chronic lower respiratory } \\
\text { diseases (J40-J47) }\end{array}$ & 6 & 1984 & 4,4 & 4 & 3344 & 4,1 & 7 & 575 & 3,8 & 9 & 944 & 2,0 & $\cdots$ & $\cdots$ & $\cdots$ & 10 & 945 & 2,3 & 10 & 2399 & 2,1 & $\cdots$ & $\cdots$ & $\cdots$ & 9 & 916 & 1,7 \\
\hline $\begin{array}{l}\text { Malignant neoplasm of } \\
\text { digestive organs (C15-C26) }\end{array}$ & 7 & 1825 & 4,0 & $\cdots$ & $\cdots$ & $\cdots$ & $\cdots$ & $\cdots$ & $\cdots$ & $\cdots$ & $\cdots$ & $\cdots$ & $\cdots$ & $\cdots$ & $\cdots$ & $\cdots$ & $\cdots$ & $\cdots$ & $\cdots$ & $\cdots$ & $\cdots$ & $\cdots$ & $\cdots$ & $\cdots$ & $\cdots$ & $\cdots$ & $\cdots$ \\
\hline $\begin{array}{l}\text { Malignant neoplasm of } \\
\text { respiratory and intrathoracic } \\
\text { organs (C30-39) }\end{array}$ & 8 & 1665 & 3,7 & $\ldots$ & & & $\ldots$ & $\ldots$ & & $\cdots$ & $\cdots$ & $\ldots$ & $\cdots$ & & & & & $\ldots$ & $\ldots$ & $\cdots$ & $\ldots$ & & & & $\ldots$ & $\cdots$ & $\cdots$ \\
\hline $\begin{array}{l}\text { Hypertensive diseases (110- } \\
\text { |15) }\end{array}$ & 9 & 1564 & 3,4 & 10 & 2112 & 2,6 & 9 & 447 & 3,0 & 7 & 1267 & 2,7 & 10 & 2631 & 2,1 & 6 & 1536 & 3,8 & 9 & 2889 & 2,5 & 9 & 1380 & 3,0 & 7 & 1525 & 2,9 \\
\hline $\begin{array}{l}\text { Other forms of heart disease } \\
(130-152)\end{array}$ & 10 & 1534 & 3,4 & 3 & 3641 & 4,4 & 5 & 582 & 3,9 & 4 & 2411 & 5,1 & 5 & 5351 & 4,2 & 4 & 2285 & 5,7 & 3 & 6152 & 5,4 & 5 & 2009 & 4,4 & 4 & 2415 & 4,6 \\
\hline $\begin{array}{l}\text { Influenza and pneumonia } \\
\text { (J10-J18) }\end{array}$ & $\cdots$ & $\cdots$ & $\cdots$ & 2 & 3689 & 4,5 & 3 & 844 & 5,6 & 1 & 5872 & 12,4 & 3 & 7197 & 5,7 & 2 & 3895 & 9,6 & 2 & 9573 & 8,3 & 2 & 4279 & 9,4 & 1 & 6424 & 12,1 \\
\hline $\begin{array}{l}\text { Intestinal infectious diseases } \\
\text { (A00-A09) }\end{array}$ & $\cdots$ & $\cdots$ & $\cdots$ & 6 & 3059 & 3,7 & 6 & 577 & 3,8 & 3 & 3190 & 6,7 & 2 & 7907 & 6,2 & 3 & 2331 & 5,8 & 4 & 4820 & 4,2 & 3 & 3493 & 7,6 & 3 & 4522 & 8,5 \\
\hline $\begin{array}{l}\text { Other viral diseases (B25- } \\
\text { B34) }\end{array}$ & $\cdots$ & $\cdots$ & $\cdots$ & 9 & 2169 & 2,6 & $\cdots$ & $\cdots$ & $\cdots$ & $\cdots$ & $\cdots$ & $\cdots$ & 8 & 3798 & 3,0 & $\cdots$ & $\cdots$ & $\cdots$ & $\cdots$ & $\cdots$ & $\cdots$ & $\cdots$ & $\cdots$ & $\cdots$ & $\ldots$ & $\cdots$ & $\ldots$ \\
\hline $\begin{array}{l}\text { Certain disorders involving } \\
\text { the immune mechanism } \\
\text { (D80-D89) }\end{array}$ & $\cdots$ & $\cdots$ & $\cdots$ & $\ldots$ & $\cdots$ & $\cdots$ & 10 & 383 & 2,5 & 5 & 2094 & 4,4 & $\ldots$ & $\ldots$ & $\cdots$ & 7 & 1282 & 3,2 & $\ldots$ & $\ldots$ & $\cdots$ & 8 & 1480 & 3,2 & 8 & 1238 & 2,3 \\
\hline $\begin{array}{l}\text { Other acute lower respiratory } \\
\text { infections (J20-J22) }\end{array}$ & $\cdots$ & $\cdots$ & $\cdots$ & $\cdots$ & $\cdots$ & $\cdots$ & $\cdots$ & $\cdots$ & $\cdots$ & $\cdots$ & $\cdots$ & $\cdots$ & 9 & 2669 & 2,1 & $\ldots$ & $\cdots$ & $\cdots$ & $\cdots$ & $\cdots$ & $\cdots$ & 10 & 1077 & 2,4 & $\cdots$ & $\cdots$ & $\cdots$ \\
\hline $\begin{array}{l}\text { Inflammatory diseases of the } \\
\text { central nervous system (G00- } \\
\text { G09) }\end{array}$ & . & $\cdots$ & $\ldots$ & $\ldots$ & $\ldots$ & $\ldots$ & $\ldots$ & $\ldots$ & $\cdots$ & $\ldots$ & $\cdots$ & $\ldots$ & $\ldots$ & $\ldots$ & $\ldots$ & $\ldots$ & $\ldots$ & $\ldots$ & $\cdots$ & $\ldots$ & $\ldots$ & $\ldots$ & & $\ldots$ & 10 & 717 & 1,4 \\
\hline Other natural causes & & 17283 & 38,1 & & 37333 & 45,5 & & 6970 & 46,2 & & 19319 & 40,9 & & 50498 & 39,6 & & 16611 & 41,1 & & 53245 & 46,4 & & 16381 & 35,8 & & 22262 & 42,1 \\
\hline Non-natural causes & & 5282 & 11,6 & & 7216 & 8,8 & & 1275 & 8,5 & & 3128 & 6,6 & & 10799 & 8,5 & & 2890 & 7,2 & & 10857 & 9,5 & & 3971 & 8,7 & & 3871 & 7,3 \\
\hline All causes & & 45398 & 100,0 & & 82132 & 100,0 & & 15082 & 100,0 & & 47265 & 100,0 & & 127369 & 100,0 & & 40372 & 100,0 & & 114729 & 100,0 & & 45703 & 100,0 & & 52907 & 100,0 \\
\hline
\end{tabular}

*Including deaths due to MDR-TB and XDR-TB

Rank

Category not in top ten 


\section{Underlying causes of death (main groups) by district municipality of death occurrence}

The main groups of underlying causes of death by district municipalities are provided in Appendix M to M.2 and Appendices N to N.8. Appendices M to M.2 provide the number of deaths by main groups of causes of death for each district municipality of death occurrence while Appendix $N$ to N.8 shows the ten leading underlying natural causes of death by district municipality of death occurrence. Information by local municipality is available on request from Stats SA.

Appendices M to M.2 show that with the exception of Western Cape, certain infectious and parasitic diseases were the most common main group of causes of death in all provinces. This main group affected at least $30 \%$ of deaths occurring in KwaZulu-Natal (31,7\%) and Mpumalanga (30,0\%). Only 18,5\% of deaths occurring in Western Cape were due to certain infectious and parasitic diseases. The district municipalities worst affected by certain infectious and parasitic diseases were those in KwaZulu-Natal, particularly Umkhanyakude (37,8\%), iLemebe $(37,6 \%)$, Uthungulu (36,6\%) and Zululand (36,6\%).

Diseases of the respiratory system were more prevalent in Free State and Mpumalanga where these causes contributed $17,7 \%$ and $15,8 \%$ of all deaths in these provinces, respectively. With regard to district municipalities, over $20 \%$ of deaths in Greater Sekhukhune, Limpopo (26,1\%), Amajuba, KwaZulu-Natal (22,0\%), Ngaka Modiri Molema, North West $(21,8)$, Thabo Mofutsanyane, Free State $(21,1 \%)$ and Lejweleputswa, Free State $(20,6 \%)$ were due to diseases of the respiratory system.

Western Cape had the highest proportion of deaths due to diseases of the circulatory system (19,4\%) and neoplasms $(15,8 \%)$. Diseases of the circulatory system were also the most common cause of death for all district municipalities in this province, with the exception of Cape Winelands where the most common main group of death was certain infectious and parasitic diseases.

Information on the ten leading natural causes of death by district municipality (Appendix N to N.8) shows that, with the exception of three districts, the leading causes were either tuberculosis or influenza and pneumonia. Tuberculosis was the leading cause of death in the majority of district municipalities in seven provinces: all in Western Cape, Eastern Cape and KwaZulu-Natal; three out of four in North West; two out of three in Mpumalanga; and three out of five in Northern Cape and Gauteng. The main exceptions were the district municipalities in Free State and Limpopo, where most people died due to influenza and pneumonia. This cause was leading in all district municipalities in Free State except in Mangaung metropolitan municipality and in two out of five district municipalities in Limpopo. Other than tuberculosis and influenza and pneumonia, other diseases that appeared as leading underlying causes in other district municipalities were other forms of heart disease (Namakwa in Northern Cape) and intestinal infectious diseases (Mopani in Limpopo, and John Taolo Gaetsewe in Northern Cape).

HIV disease was among the ten leading underlying causes of death in at least one district municipality in all provinces except Limpopo where it did not appear as a leading underlying cause of death in any of the district municipalities. It was among the ten leading causes of death in all district municipalities in Western Cape and in all except one in each of the following provinces: Eastern Cape (exception was Chris Hani), Northern Cape (exception was Namakwa), KwaZulu-Natal (exception was Amajuba), North West (exception was Ngaka Modiri Molema), and Mpumalanga (exception was Nkangala). Only one municipality in Free State (Lejweleputswa) had HIV disease among the ten leading causes of death. The districts mostly affected by HIV disease were Umkhanyakude (KwaZulu-Natal), contributing 12,4\% of all deaths in this district and Siyanda and Frances Baard both in Northern Cape, contributing $9,6 \%$ and $7,0 \%$ of deaths, respectively.

\section{Underlying causes of death by population group}

Due to a large proportion of unknown or unspecified cases, the ten leading underlying natural causes of death by population group are not discussed in this section. The discussion and distribution of underlying causes of death by population group are provided in Appendix $\mathrm{O}$ and 0.1 , respectively. 


\subsection{Non-natural causes of death}

This subsection discusses non-natural causes of death. When completing death notification forms, medical practitioners are expected to specify whether the deceased died from natural or non-natural causes. This information is provided on the first page of the death notification form and is used to issue a death certificate (see Appendix B). On the second page of the form (see Appendix B, reverse side), certifying officials are requested to indicate specific causes of death beginning with the immediate cause of death and ending with the underlying cause of death from which the underlying causes of death can be classified as natural or non-natural. This release uses the specified cause from the second page of the death notification form and the corresponding ICD-10 code to classify a death as natural or non-natural. All external causes of morbidity and mortality (codes V01 up to Y98) are treated as non-natural causes of death.

All broad groups of non-natural causes are reported in this sub-section, not just the ten leading underlying causes of death as provided for natural causes. In addition, the percentages calculated for each cause are based on all non-natural causes of death, not all causes (natural and non-natural) as was the case in the analysis of natural causes of death.

Table 4.10 shows the broad groups of non-natural causes and the associated number of deaths. It is observed that the majority of non-natural causes of death resulted from other external causes of accidental injury $(63,0 \%$ of nonnatural causes and $5,4 \%$ of all causes). Event of undetermined intent, the second most common non-natural cause of death, accounted for $13,5 \%$ of non-natural causes and 1,2\% of all causes of death. The third most common cause of non-natural deaths was transport accidents (11,5\%), followed by assault (10,3\%). Complications of medical and surgical care, intentional self-harm and sequelae of external causes of morbidity and mortality each accounted for less than $1 \%$ of non-natural causes of death.

Table 4.10: Distribution of non-natural causes of death by broad groups, 2009

\begin{tabular}{|l|r|r|r|}
\hline $\begin{array}{l}\text { Causes of death (based on the 10 } \\
\text { International Classification of Disease, 1992) }\end{array}$ & $\begin{array}{r}\text { Number } \\
\text { Other external causes of accidental injury (W00-X59) }\end{array}$ & $\begin{array}{r}\text { \% of non-natural } \\
\text { causes }\end{array}$ & $\begin{array}{r}\text { \% of all causes } \\
\text { (N=572 673) }\end{array}$ \\
\hline $\begin{array}{l}\text { Event of undetermined intent (Y10-Y34) } \\
\text { Transport accidents (V01-V99) }\end{array}$ & 31166 & 6683,0 & 13,5 \\
\hline Assault (X85-Y09) & 5674 & 11,5 & 1,2 \\
\hline Complications of medical and surgical care (Y40-Y84) & 5089 & 10,3 & 1,0 \\
\hline Intentional self-harm (X60-X84) & 438 & 0,9 & 0,9 \\
\hline $\begin{array}{l}\text { Sequelae of external causes of morbidity and mortality } \\
\text { (Y85-Y89) }\end{array}$ & 373 & 0,8 & 0,1 \\
\hline All non-natural causes & 33 & 0,1 & 0,1 \\
\hline
\end{tabular}

A breakdown of deaths due to other external causes of accidental injury is provided in Table 4.11 to provide information that can be used for a better understanding of deaths due to this cause, which comprised nearly twothirds of all non-natural deaths. The table shows that over half of these deaths were due to accidental exposure to other and unspecified factors, mainly exposure to unspecified factor (including accident not elsewhere classified and exposure not elsewhere classified). The next common cause was exposure to inanimate mechanical forces (98,3\% of these due to discharge from other and unspecified firearms), followed by other accidental threats to breathing (62,8\% of these due to other accidental hanging and strangulation) and exposure to smoke, fire and flames. 
Table 4.11: Distribution of deaths due to other external causes of accidental injury, 2009

\begin{tabular}{|l|r|r|}
\hline $\begin{array}{l}\text { Causes of death (based on the 10 } \\
\text { Disease, 1992) }\end{array}$ & Number & $\%$ \\
\hline Accidental exposure to other and unspecified factors (X58-X59) & 16748 & 53,7 \\
\hline Exposure to inanimate mechanical forces (W20-W49) & 4814 & 15,4 \\
\hline Other accidental threats to breathing (W75-W84) & 4331 & 13,9 \\
Exposure to smoke, fire and flames (X00-X09) & 2241 & 7,2 \\
\hline Accidental drowning and submersion (W65-W74) & 1412 & 4,5 \\
\hline Accidental poisoning by and exposure to noxious substances (X40-X49) & 826 & 2,7 \\
Exposure to forces of nature (X30-X39) & 324 & 1,0 \\
\hline $\begin{array}{l}\text { Exposure to electric current, radiation and extreme ambient air temperature and } \\
\text { pressure (W85-W99) }\end{array}$ & 237 & 0,8 \\
\hline Falls (W00-W19) & 125 & 0,4 \\
\hline Contact with venomous animals and plants (X20-X29) & 57 & 0,2 \\
\hline Exposure to animate mechanical forces (W50-W64) & 32 & 0,1 \\
\hline Contact with heat and hot substances (X10-X19) & 13 & 6,0 \\
\hline Overexertion, travel and privation (X50-X57) & 6 & $\mathbf{3 1} 166$ \\
\hline Total & $\mathbf{1 0 0 , 0}$ \\
\hline
\end{tabular}

\section{Non-natural causes of death by age and sex}

Table 4.12 shows the distribution of non-natural causes of death by sex and broad age groups $(0-14,15-49,50-$ 64 and 65 and older) for deaths that occurred in 2009. The numbers and percentages of deaths for both sexes presented in this table are not the same as the ones presented in Table 4.10 as information in Table 4.12 excludes deaths with unspecified age. It is noted that the order of the causes of death for both sexes and for male and for females was generally the same, with other external cause of accidental injury leading the non-natural causes of death, followed by event of undetermined intent.

The results show that the age group mostly affected by non-natural causes of death was age group 15-49 for both sexes, accounting for $13,8 \%$ of all deaths in this age group. The age group least affected by non-natural causes was those aged 65 years and older where less than $3 \%(2,6 \%)$ of deaths in this age group were due to non-natural causes. Excluding deaths due to other external causes of accidental injury and event of undetermined intent, it is observed that with the exception of those aged 15-49 years, transport accidents were the most common nonnatural causes of death in all age groups. Assault was more common among those aged 15-49, affecting 12,8\% of non-natural deaths in this age group. The same observation was made for males. In the case of females, transport accidents were more common for all age groups.

Differences by sex show that males had a higher proportion of deaths due to non-natural causes $(12,9 \%)$ as compared to females $(4,1 \%)$. Furthermore, for each of the age groups, males had a higher proportion of deaths due to non-natural causes than females, with the gap much wider at age group 15-49 where as much as $21,5 \%$ of male deaths resulted from non-natural causes compared to $5,2 \%$ of females in the same age group. In terms of absolute numbers, the total number of male deaths due to non-natural causes was more than three times the total number of female deaths (37 752 versus 11243 ). The differences were particularly wide in age group 15-49 where male deaths exceeded female deaths by 4,6 times.

For specific causes, the main difference between males and females was the percentage of deaths due to assault and complications of medical and surgical care. On one hand, as much as $11,6 \%$ of male non-natural deaths were due to assault, while $6,0 \%$ of female deaths were due to the same cause. On the other hand, $2,0 \%$ of female nonnatural deaths were due to complications of medical and surgical care while $0,6 \%$ of male deaths were due to the same cause. Furthermore, for each of the age groups (with the exception of those aged 65 years and older), females had a higher proportion of deaths due to transport accidents than males, while males had a higher proportion of deaths due to assault than females, with the exception of age group 50-64. 
Table 4.12: Underlying non-natural causes of death by age group and sex, 2009

\begin{tabular}{|c|c|c|c|c|c|c|c|c|c|c|}
\hline \multirow{2}{*}{$\begin{array}{l}\text { Causes of death (based on the } 10^{\text {th }} \text { Revision, International } \\
\text { Classification of Disease, } 1992\end{array}$} & \multicolumn{5}{|c|}{ Number } & \multicolumn{5}{|c|}{ Percentage } \\
\hline & $0-14$ & $15-49$ & $50-64$ & $65+$ & Total & $0-14$ & $15-49$ & $50-64$ & $65+$ & Total \\
\hline \multicolumn{11}{|l|}{ Both sexes $^{*}$} \\
\hline Other external causes of accidental injury (W00-X59) & 3461 & 20824 & 3752 & 2870 & 30907 & 73,3 & 60,1 & 65,3 & 72,4 & 63,0 \\
\hline Event of undetermined intent (Y10-Y34) & 468 & 4975 & 786 & 388 & 6617 & 9,9 & 14,4 & 13,7 & 9,8 & 13,5 \\
\hline Transport accidents (V01-V99) & 637 & 3891 & 753 & 356 & 5637 & 13,5 & 11,2 & 13,1 & 9,0 & 11,5 \\
\hline Assault (X85-Y09) & 79 & 4434 & 350 & 193 & 5056 & 1,7 & 12,8 & 6,1 & 4,9 & 10,3 \\
\hline Complications of medical and surgical care (Y40-Y84) & 66 & 192 & 56 & 124 & 438 & 1,4 & 0,6 & 1,0 & 3,1 & 0,9 \\
\hline Intentional self-harm (X60-X84) & 9 & 300 & 43 & 21 & 373 & 0,2 & 0,9 & 0,7 & 0,5 & 0,8 \\
\hline Sub-total & 4720 & 34632 & 5745 & 3964 & 49061 & 100,0 & 100,0 & 100,0 & 100,0 & 100,0 \\
\hline Non-natural causes & 4720 & 34632 & 5745 & 3964 & 49061 & 8,0 & 13,8 & 5,3 & 2,6 & 8,6 \\
\hline Natural & 54461 & 217023 & 101810 & 149029 & 522323 & 92,0 & 86,2 & 94,7 & 97,4 & 91,4 \\
\hline All causes & 59181 & 251655 & 107555 & 152993 & 571384 & 100,0 & 100,0 & 100,0 & 100,0 & 100,0 \\
\hline \multicolumn{11}{|l|}{ Male $^{\star \star}$} \\
\hline Other external causes of accidental injury (W00-X59) & 2093 & 17093 & 2875 & 1478 & 23539 & 74,1 & 60,1 & 65,5 & 70,3 & 62,4 \\
\hline Event of undetermined intent (Y10-Y34) & 268 & 4028 & 600 & 223 & 5119 & 9,5 & 14,2 & 13,7 & 10,6 & 13,6 \\
\hline Transport accidents (V01-V99) & 375 & 3034 & 573 & 217 & 4199 & 13,3 & 10,7 & 13,1 & 10,3 & 11,1 \\
\hline Assault (X85-Y09) & 50 & 3951 & 266 & 112 & 4379 & 1,8 & 13,9 & 6,1 & 5,3 & 11,6 \\
\hline Intentional self-harm $(\mathrm{X} 60-\mathrm{X} 84)$ & 7 & 224 & 38 & 12 & 281 & 0,2 & 0,8 & 0,9 & 0,6 & 0,7 \\
\hline Sequelae of external causes of morbidity and mortality (Y85-Y89) & 0 & 13 & 2 & 8 & 23 & 0,0 & 0,0 & 0,0 & 0,4 & 0,1 \\
\hline Sub-total & 2824 & 28440 & 4387 & 2101 & 37752 & 100,0 & 100,0 & 100,0 & 100,0 & 100,0 \\
\hline Non-natural causes & 2824 & 28440 & 4387 & 2101 & 37752 & 9,0 & 21,5 & 7,0 & 3,2 & 12,9 \\
\hline Natural & 28691 & 103948 & 58558 & 64360 & 255557 & 91,0 & 78,5 & 93,0 & 96,8 & 87,1 \\
\hline All causes & 31515 & 132388 & 62945 & 66461 & 293309 & 100,0 & 100,0 & 100,0 & 100,0 & 100,0 \\
\hline \multicolumn{11}{|l|}{ Female $^{\star * \star}$} \\
\hline Other external causes of accidental injury (W00-X59) & 1355 & 3700 & 876 & 1389 & 7320 & 72,1 & 60,2 & 64,6 & 74,7 & 65,1 \\
\hline Event of undetermined intent (Y10-Y34) & 199 & 940 & 186 & 165 & 1490 & 10,6 & 15,3 & 13,7 & 8,9 & 13,3 \\
\hline Transport accidents (V01-V99) & 262 & 855 & 180 & 139 & 1436 & 13,9 & 13,9 & 13,3 & 7,5 & 12,8 \\
\hline Assault (X85-Y09) & 27 & 477 & 84 & 81 & 669 & 1,4 & 7,8 & 6,2 & 4,4 & 6,0 \\
\hline Complications of medical and surgical care (Y40-Y84) & 35 & 95 & 23 & 73 & 226 & 1,9 & 1,5 & 1,7 & 3,9 & 2,0 \\
\hline Intentional self-harm (X60-X84) & 2 & 76 & 5 & 9 & 92 & 0,1 & 1,2 & 0,4 & 0,5 & 0,8 \\
\hline Sequelae of external causes of morbidity and mortality (Y85-Y89) & 0 & 3 & 3 & 4 & 10 & 0,0 & 0,0 & 0,2 & 0,2 & 0,1 \\
\hline Sub-total & 1880 & 6146 & 1357 & 1860 & 11243 & 100,0 & 100,0 & 100,0 & 100,0 & 100,0 \\
\hline Non-natural causes & 1880 & 6146 & 1357 & 1860 & 11243 & 6,9 & 5,2 & 3,0 & 2,2 & 4,1 \\
\hline Natural & 25314 & 112786 & 43175 & 84627 & 265902 & 93,1 & 94,8 & 97,0 & 97,8 & 95,9 \\
\hline All causes & 27194 & 118932 & 44532 & 86487 & 277145 & 100,0 & 100,0 & 100,0 & 100,0 & 100,0 \\
\hline
\end{tabular}




\section{Non-natural causes of death by province of death occurrence}

The distribution of the underlying non-natural causes of death by province for 2009 is shown in Table 4.13. It is observed that Western Cape had the highest proportion of deaths due to non-natural causes $(11,6 \%)$, followed by Gauteng (9,5\%); Eastern Cape (8,8\%); and Mpumalanga (8,7\%). All these provinces exceeded the national average of $8,6 \%$ of deaths due to non-natural causes in 2009 . The lowest proportion of deaths due to non-natural causes were observed in Free State $(6,6 \%)$, North West $(7,2 \%)$ and Limpopo $(7,3 \%)$.

The most common causes of non-natural deaths in all provinces were other external causes of accidental injury but the proportion due to this cause was lowest in Limpopo (42,6\%) and highest in Mpumalanga $(84,9 \%)$. The second leading causes of non-natural deaths differed by province. Event of undetermined intent was the second leading non-natural cause of death in KwaZulu-Natal, North West and Gauteng. Assault was the second leading non-natural cause of death in Western Cape, Eastern Cape and Northern Cape. Transport accidents were the second leading cause of non-natural causes in Free State, Mpumalanga and Limpopo. Complications of medical and surgical care, intentional self-harm and sequelae of external causes of morbidity and mortality were least common, each affecting less than $2,5 \%$ of non-natural deaths in each province.

The highest proportion of deaths due to transport accidents was observed in Limpopo where over a third $(37,0 \%)$ of non-natural cases were due to this cause; assault was highest in Western Cape $(19,7 \%)$; and intentional self-harm highest in Northern Cape (2,4\%). Conversely the proportion of deaths due to transport accidents was lowest in Gauteng (5,0\%); and assault lowest in Mpumalanga (3,1\%).

\section{Non-natural causes of death by district municipalities}

The information provided in Appendix N to N.8 also shows the proportion of deaths due to non-natural causes for each of the district municipalities. The lowest percentage of deaths due to non-natural causes was observed in North West in Dr Ruth Segomotsi Mompati where 5,4\% of deaths in this district was due to non-natural causes of death. The highest was observed in Western Cape in Central Karoo where nonnatural causes contributed 16,9\% of all deaths in this district. All districts in Western Cape had at least $10 \%$ of their deaths resulting from non-natural causes. Conversely, at most, $8 \%$ of deaths in each district in Free State were due to non-natural causes. 


\section{Table 4.13: Underlying non-natural causes of death by province, 2009}

\begin{tabular}{|c|c|c|c|c|c|c|c|c|c|c|c|c|c|c|c|c|c|c|}
\hline \multirow{2}{*}{$\begin{array}{l}\text { Causes of death (based on the } 10^{\text {th }} \\
\text { Revision, International Classification of } \\
\text { Disease, 1992) }\end{array}$} & \multicolumn{2}{|c|}{ Western Cape } & \multicolumn{2}{|c|}{ Eastern Cape } & \multicolumn{2}{|c|}{ Northern Cape } & \multicolumn{2}{|c|}{ Free State } & \multicolumn{2}{|c|}{ KwaZulu-Natal } & \multicolumn{2}{|c|}{ North West } & \multicolumn{2}{|c|}{ Gauteng } & \multicolumn{2}{|c|}{ Mpumalanga } & \multicolumn{2}{|c|}{ Limpopo } \\
\hline & No. & $\%$ & No. & $\%$ & No. & $\%$ & No. & $\%$ & No. & $\%$ & No. & $\%$ & No. & $\%$ & No. & $\%$ & No. & $\%$ \\
\hline $\begin{array}{l}\text { Other external causes of accidental injury } \\
\text { (W00-X59) }\end{array}$ & 3106 & 58,8 & 3970 & 55,0 & 843 & 66,1 & 1761 & 56,3 & 7014 & 65,0 & 1633 & 56,5 & 7713 & 71,0 & 3373 & 84,9 & 1650 & 42,6 \\
\hline Event of undetermined intent (Y10-Y34) & 516 & 9,8 & 1150 & 15,9 & 45 & 3,5 & 263 & 8,4 & 1692 & 15,7 & 537 & 18,6 & 1886 & 17,4 & 79 & 2,0 & 500 & 12,9 \\
\hline Transport accidents (V01-V99) & 486 & 9,2 & 764 & 10,6 & 137 & 10,7 & 547 & 17,5 & 993 & 9,2 & 410 & 14,2 & 540 & 5,0 & 330 & 8,3 & 1434 & 37,0 \\
\hline Assault (X85-Y09) & 1038 & 19,7 & 1247 & 17,3 & 213 & 16,7 & 488 & 15,6 & 860 & 8,0 & 275 & 9,5 & 610 & 5,6 & 125 & 3,1 & 220 & 5,7 \\
\hline $\begin{array}{l}\text { Complications of medical and surgical care } \\
\text { (Y40-Y84) }\end{array}$ & 42 & 0,8 & 60 & 0,8 & 4 & 0,3 & 46 & 1,5 & 94 & 0,9 & 24 & 0,8 & 88 & 0,8 & 38 & 1,0 & 39 & 1,0 \\
\hline $\begin{array}{l}\text { Sequelae of external causes of morbidity } \\
\text { and mortality (Y85-Y89) }\end{array}$ & 6 & 0,1 & 3 & 0,0 & 2 & 0,2 & 2 & 0,1 & 9 & 0,1 & 1 & 0,0 & 6 & 0,1 & 2 & 0,1 & 2 & 0,1 \\
\hline Subtotal & 5282 & 31,4 & 7216 & 29,0 & 1275 & 30,4 & 3128 & 35,3 & 10799 & 19,4 & 2890 & 24,9 & 10857 & 11,6 & 3971 & 13,1 & 3871 & 44,5 \\
\hline Non-natural causes & 5282 & 11,6 & 7216 & 8,8 & 1275 & 8,5 & 3128 & 6,6 & 10799 & 8,5 & 2890 & 7,2 & 10857 & 9,5 & 3971 & 8,7 & 3871 & 7,3 \\
\hline Natural causes & 40116 & 88,4 & 74916 & 91,2 & 13807 & 91,5 & 44137 & 93,4 & 116570 & 91,5 & 37482 & 92,8 & 103872 & 90,5 & 41732 & 91,3 & 49036 & 92,7 \\
\hline All causes & 45398 & 100,0 & 82132 & 100,0 & 15082 & 100,0 & 47265 & 100,0 & 127369 & 100,0 & 40372 & 100,0 & 114729 & 100,0 & 45703 & 100,0 & 52907 & 100,0 \\
\hline
\end{tabular}




\subsection{Comparison between immediate, contributing and underlying causes of death}

The second page of the death notification form makes provision for several causes to be reported on each form, with a maximum of six causes recorded on death notification forms in 2009. Causes recorded can be indicated as immediate, contributing or underlying. For the 2009 deaths, the majority of forms for 2009 deaths $(59,0 \%)$ had just one cause of death indicated, with $41,0 \%$ having two or more causes.

This section provides information on the total number of causes of death reported on each form. Table 4.14 shows the total number of times specific causes of death were recorded on the 2009 death notification forms as either underlying, immediate or contributing causes for the 20 most commonly reported causes of death. The list includes natural and non-natural causes, as well as deaths due to symptoms, signs and abnormal clinical and laboratory findings, not elsewhere classified.

Tuberculosis was the most frequently recorded cause of death in 2009, mentioned in a total of 82821 death notification forms, followed by ill-defined and unknown cause of mortality mentioned in 74853 forms. That is, $14,5 \%$ and $13,1 \%$ of all death notification forms had tuberculosis and ill-defined and unknown cause of mortality, respectively, recorded as either immediate, contributing or underlying cause of death. The third most commonly mentioned cause, representing $12,3 \%$ of deaths was influenza and pneumonia. Other external causes of accidental injury were the eighth most commonly mentioned causes $(5,7 \%)$ and the only non-natural cause appearing among the 20 most commonly mentioned causes of death. Certain disorders involving the immune mechanism was the ninth most commonly mentioned cause of death $(4,5 \%)$, other viral diseases was the tenth $(4,1 \%)$ and HIV disease was on seventeenth place $(3,1 \%)$.

Based on the 20 most commonly mentioned causes, the most common main groups of causes of death mentioned on death notification forms in 2009 were certain infectious and parasitic diseases, diseases of the circulatory system and diseases of the respiratory system. Almost a third $(31,6 \%)$ of forms mentioned certain infectious and parasitic diseases on the 2009 forms, while diseases of the circulatory system were mentioned on $25,6 \%$ of the forms, and diseases of the respiratory system in $22,0 \%$ of the forms.

Table 4.14: Distribution of the 20 most commonly reported causes of death, 2009

\begin{tabular}{|c|c|c|c|}
\hline Rank & $\begin{array}{l}\text { Causes of death (based on the } 10^{\text {th }} \text { Revision, International } \\
\text { Classification of Disease, 1992) }\end{array}$ & $\begin{array}{r}\text { Number of deaths } \\
\text { in which the cause } \\
\text { was reported }\end{array}$ & $\%$ of all deaths \\
\hline 1 & Tuberculosis (A15-A19)* & 82821 & 14,5 \\
\hline 2 & III-defined and unknown causes of mortality (R95-R99) & 74853 & 13,1 \\
\hline 3 & Influenza and pneumonia (J09-J18) & 70250 & 12,3 \\
\hline 4 & Other forms of heart disease (I30-I52) & 56112 & 9,8 \\
\hline 5 & Hypertensive diseases (I10-I15) & 37131 & 6,5 \\
\hline 6 & Cerebrovascular diseases (I60-I69) & 35226 & 6,2 \\
\hline 7 & Intestinal infectious diseases (A00-A09) & 35199 & 6,1 \\
\hline 8 & Other external causes of accidental injury (W00-X59) & 32600 & 5,7 \\
\hline 9 & Certain disorders involving the immune mechanism (D80-D89) & 25975 & 4,5 \\
\hline 10 & Other viral diseases (B25-B34) & 23330 & 4,1 \\
\hline 11 & Diabetes mellitus (E10-E14) & 22991 & 4,0 \\
\hline 12 & Metabolic disorders (E70-E90) & 21609 & 3,8 \\
\hline 13 & Other bacterial diseases (A30-A49) & 21385 & 3,7 \\
\hline 14 & Other diseases of the respiratory system (J95-J99) & 20493 & 3,6 \\
\hline 15 & Chronic lower respiratory diseases (J40-J47) & 19824 & 3,5 \\
\hline 16 & Renal failure (N17-N19) & 19133 & 3,3 \\
\hline 17 & Human immunodeficiency virus [HIV] disease (B20-B24) & 18039 & 3,1 \\
\hline 18 & Ischaemic heart diseases (I20-I25) & 17975 & 3,1 \\
\hline 19 & General symptoms and signs (R50-R69) & 16860 & 2,9 \\
\hline 20 & Other acute lower respiratory infections (J20-J22) & 15154 & 2,6 \\
\hline
\end{tabular}

*Including deaths due to $M D R-T B$ and $X D R-T B$. 
All the natural underlying causes of death that appeared among the ten leading causes of death also appeared among the 20 most commonly mentioned causes. The ten leading underlying natural causes of death shown in Table 4.4 for 2009 deaths are presented in Table 4.15 to show the breakdown of the number of deaths by whether the death was selected as the underlying cause or whether it was reported as the immediate or contributing cause.

Within each category, the counts of underlying causes and immediate or contributing causes are not duplicated, so that they can be summed up to equal the total number of times a specific cause of death was recorded on a death notification form. For example, 69003 deaths had tuberculosis as the underlying cause and another 13818 deaths had it as an immediate or contributing cause. This gives a total of 82821 death notification forms that had tuberculosis mentioned on them.

The table shows that in over $80 \%$ of deaths where HIV disease $(97,4 \%)$, diabetes mellitus $(89,3 \%)$, intestinal infectious diseases $(87,1 \%)$ and tuberculosis $(83,3 \%)$ were mentioned, they were selected as underlying causes. In less than half of the cases where other forms of heart disease $(47,2 \%)$ and hypertensive diseases $(41,4 \%)$ were mentioned, they were selected as the underlying causes.

Table 4.15: Number and percentage of deaths selected as underlying or reported as immediate or contributing causes of death: 2009

\begin{tabular}{|c|c|c|c|c|c|c|c|}
\hline \multirow{2}{*}{$\begin{array}{l}\text { Causes of death (based on the } 10^{\text {th }} \\
\text { Revision, International Classification of } \\
\text { Disease, 1992) }\end{array}$} & \multirow{2}{*}{$\begin{array}{l}\text { Under- } \\
\text { lying } \\
\text { rank }\end{array}$} & \multicolumn{3}{|c|}{ Number of deaths } & \multicolumn{3}{|c|}{ Percentage of any mention } \\
\hline & & Underlying & $\begin{array}{r}\text { Immediate } \\
\text { or } \\
\text { contributing }\end{array}$ & $\begin{array}{l}\text { Total } \\
\text { recorded }\end{array}$ & Underlying & $\begin{array}{r}\text { Immediate } \\
\text { or } \\
\text { contributing }\end{array}$ & $\begin{array}{r}\text { Total } \\
\text { recorded }\end{array}$ \\
\hline Tuberculosis (A15-A19)* & 1 & 69003 & 13818 & 82821 & 83,3 & 16,7 & 100,0 \\
\hline Influenza and pneumonia (J09-J18) & 2 & 42964 & 27286 & 70250 & 61,2 & 38,8 & 100,0 \\
\hline Intestinal infectious diseases (A00-A09) & 3 & 30675 & 4524 & 35199 & 87,1 & 12,9 & 100,0 \\
\hline Other forms of heart disease (I30-I52) & 4 & 26462 & 29650 & 56112 & 47,2 & 52,8 & 100,0 \\
\hline Cerebrovascular diseases (160-169) & 5 & 24835 & 10391 & 35226 & 70,5 & 29,5 & 100,0 \\
\hline Diabetes mellitus (E10-E14) & 6 & 20523 & 2468 & 22991 & 89,3 & 10,7 & 100,0 \\
\hline $\begin{array}{l}\text { Human immunodeficiency virus [HIV] disease } \\
\text { (B20-B24) }\end{array}$ & 7 & 17570 & 469 & 18039 & 97,4 & 2,6 & 100,0 \\
\hline Hypertensive diseases (I10-I15) & 8 & 15386 & 21745 & 37131 & 41,4 & 58,6 & 100,0 \\
\hline Chronic lower respiratory diseases (J40-J47) & 9 & 14184 & 5640 & 19824 & 71,5 & 28,5 & 100,0 \\
\hline $\begin{array}{l}\text { Certain disorders involving the immune } \\
\text { mechanism (D80-D89) }\end{array}$ & 10 & 13096 & 12879 & 25975 & 50,4 & 49,6 & 100,0 \\
\hline
\end{tabular}

*Including deaths due to MDR-TB and XDR-TB. 


\section{Summary and concluding remarks}

This statistical release has provided information on mortality and causes of death for deaths that occurred in 2009 as well as information on death occurrences from 1997 to 2008 to provide recent trends in mortality. The release is based on data on deaths collected through the civil registration system in South Africa, maintained by the Department of Home Affairs (DHA). The information on mortality and causes of death can be used to assess the well-being and health status of a population with the aim of preventing or reducing premature mortality and improving the quality of life.

A total of 572673 deaths that occurred in 2009 were registered at DHA and processed at Statistics South Africa (Stats SA) during the 2010/11 processing phase. The results show that mortality continues to decrease in the country as observed from 2007 in the data processed by Stats SA and in the number of deaths recorded in the national population register. The total number of deaths processed by Stats SA decreased by 1,5\% between 2007 and 2008 and by 3,8\% between 2008 and 2009. The decrease was also observed for male and female deaths, with female deaths declining at a higher rate than male deaths. Other indicators showing decreasing mortality were crude death rates and median ages at death.

The majority of deaths occurred among the black African population group and most deaths occurred in healthcare facilities even though about $30 \%$ still occurred at home. The highest number of deaths occurred in KwaZulu-Natal, followed by Gauteng and Eastern Cape, the provinces which also have the largest population sizes in the country.

Information on causes of death showed that the majority of deaths were due to natural causes, mainly from the main group of certain infectious and parasitic diseases, responsible for a quarter of all deaths. The number of both natural and non-natural causes decreased between 2008 and 2009, with non-natural deaths decreasing at a higher rate than natural causes (7,2\% for non-natural causes and 3,4\% for natural causes).

Tuberculosis continued to be the leading cause of death in South Africa, accounting for $12 \%$ of deaths in the country. This cause has been the leading cause of death in the country since 1997. Influenza and pneumonia was the second leading cause, followed by intestinal infectious diseases, other forms of heart disease and cerebrovascular diseases. HIV disease was the seventh leading cause of death and accounted for $3,1 \%$ of all deaths in 2009.

Between 2007 and 2009, the number of deaths consistently decreased for tuberculosis, influenza and pneumonia, chronic lower respiratory diseases and certain disorders involving the immune mechanism and consistently increased for other forms of heart disease, HIV disease and hypertensive diseases. Although the overall number of deaths due to tuberculosis is decreasing, those due to multidrug-resistant tuberculosis and extensively drugresistant tuberculosis continue to increase at a high rate.

The analysis of causes of death, according to sex, shows that eight of the ten leading causes were similar for males and females. The difference between the leading causes of death for males and females was that hypertensive diseases and other viral diseases were among the ten leading causes of death for females only while chronic lower respiratory diseases and ischaemic heart diseases were among the ten leading causes only for the males. HIV disease was the sixth leading cause of death for males, contributing $2,9 \%$ of male deaths in 2009 while it ranked eighth for the females, contributing $3,3 \%$ of female deaths.

Differences by provinces show that tuberculosis was the leading cause of death in all provinces, with the exception of Free State and Limpopo where influenza and pneumonia was the leading cause of death. Tuberculosis was also the leading cause of death in the majority of district municipalities. Other causes that appeared as leading causes in other district municipalities were intestinal infectious diseases and other forms of heart disease.

Respiratory and cardiovascular disorders specific to the perinatal period was the leading cause of death for infants in the neonatal period while intestinal infectious diseases were the leading causes of death for all infants (aged 0), among those aged 1-4 years and for the population aged 0-14. Tuberculosis was the leading cause of death in age groups 15-24, 15-49 and 50-64 and cerebrovascular diseases the leading cause in the 65 years and older age group.

The majority of non-natural causes of death were due to other external causes of accidental injury, and accounted for nearly two-thirds of all non-natural deaths. The highest percentage of deaths due to non-natural causes was observed for those aged 15-19 compared to other age groups; and the number of deaths was generally higher for males of all age groups compared to females. Also, compared to other provinces, the province of death occurrence that had the highest number of deaths was Western Cape. Transport accidents contributed $11,5 \%$ of non-natural causes while assault contributed 10,3\%. Deaths due to transport accidents were particularly high in Limpopo, 
accounting for $37,0 \%$ of non-natural deaths, while those due to assault were highest in Northern Cape, causing $16,7 \%$ of non-natural deaths.

While the completeness of death registration has improved over time, currently estimated at around $93 \%$, coupled with timely registration of death occurrence, there are still concerns about the quality of the content of both mortality statistics and causes of death statistics. Some variables on the death notification forms are not completed fully, particularly for population group, education, smoking status, pregnancy status, occupation and industry. In addition, there is a high percentage of deaths $(13,7 \%)$ classified to symptoms, signs and abnormal clinical findings. Furthermore, it takes about two years from the end of the reference period to the publication of information of a specific year.

The status of the quality of content on mortality and causes of death data has not changed much over time. As such, areas of improvement identified include accurate and fully completed information on the death notification forms; correct and detailed certification of causes of death; and timely publication of information on mortality and causes of death. Concerted efforts between the public, the Department of Home Affairs, the Department of Health and Stats SA are needed for timely, accurate and relevant information on mortality and causes of death in the country.

To facilitate further analysis of data on mortality and causes of death, Stats SA provides a dataset on a compact disc and on the Stats SA website. The dataset includes variables presented in this statistical release, as well as several others that are not part of this release, with the expectation that further expert analyses of the data will assist to improve the quality of the data. 


\section{References}

Bennett, N. G. and S. Horiuchi, 1981. "Estimating the Completeness of Death Registration in a Closed Population." Population Index, 47(2): 207-21.

Bennett, N. G. and S. Horiuchi, 1984. "Mortality estimation from registered deaths in less developed countries", Demography, 21(2): 217-234.

Department of Health. 2011. "Health Data Advisory and Coordination Committee Report", Department of Health, Pretoria.

Dorrington R. E and D. Bradshaw. 2011. "Maternal mortality in South Africa: lessons from a case study in the use of deaths reported by households in censuses and survey", Journal of Population Research 28: 49-73.

Hill, K., 1987. "Estimating Census and Death Registration Completeness", Asian and Pacific Population Forum, 1(3): 8-13, 23-24.

Khoza, C. (forthcoming). "An assessment of quality of death registration data for mortality estimation in South Africa".

Mahapatra Prasanta, Kenji Shibuya, Alan D Lopez, Francesca Coullare, Francis C Notzon, Simon Szreter on behalf of the Monitoring Vital Events (MoVE) writing group, 2007. "Civil registration systems and vital statistics: successes and missed opportunities”, The Lancet, 370 (10): 1653-1663.

Preston S. and Hill K., 1980. "Estimating completeness of death registration", Population Studies, 34(2): 349-366.

Republic of South Africa, 1992. Births and Deaths Registration Act, 1992 (Act No. 51 of 1992).

Republic of South Africa, 1959. Inquests Act, 1959 (Act No. 58 of 1959).

Stats SA (Statistics South Africa), 2002. Guidelines for coders using ICD-10. Pretoria: Statistics South Africa.

Stats SA (Statistics South Africa), 2011. Mid-year population estimates, South Africa (2011), derived from interactive time series data. Pretoria: Statistics South Africa.

WHO (World Health Organization), 1992. International classification of diseases and related health problems, Tenth Revision. Geneva: World Health Organization.

WHO (World Health Organization), 2003, Epidemiology and Burden of Disease, Geneva: World Health Organization.

WHO (World Health Organization), 2007. "Civil registration: why counting births and deaths is important", Fact sheet Number 324, October 2007, available at http://www.who.int/mediacentre/factsheets/fs324/en/index.html. Accessed on 29 September 2009. 


\section{Appendices}

\section{Appendix A: Definitions}

Causes of death are all those diseases, morbid conditions, or injuries that either resulted in or contributed to death, and the circumstances of the accident or violence which produced any such injuries.

Contributing causes of death are morbid conditions, if any, giving rise to the immediate cause of death.

Death is a permanent disappearance of all evidence of life at any time after a live birth has taken place.

Human immunodeficiency virus (HIV) is the pathogenic organism responsible for the acquired immunodeficiency syndrome (AIDS), also known as the lymphadenopathy virus (LAV).

Immediate cause of death is the disease or condition directly leading to death.

Leading underlying causes of death are the most frequent underlying causes of death in any given population. In this release, the underlying causes of death are ranked according to frequency.

Live birth is the complete expulsion or extraction from its mother's womb of a product of conception, irrespective of the duration of the pregnancy, which after such separation, breathes or shows any other evidence of life.

Multiple causes of death are all morbid conditions, diseases and injuries entered on the death certificate. These include those involved in the morbid train of events leading to the death which were classified as either the underlying cause, the intermediate cause, or any intervening cause and those conditions which contributed to death but were not related to the disease or condition causing death.

Neonatal death is the death of a live-born child during the first 28 completed days of life.

Post-neonatal death is a live-born infant dying after 28 completed days of birth but before the first year of life is completed.

Population group: According to the Population Registration Act Repeal Act (No. 114 of 1991), the South African Population Register no longer stores information regarding the population group of individuals whose details are on the register. This Repeal Act is still in place; therefore, the population group used in this report refers to the population group as identified by the certifying physician/professional nurse on the death notification form and is only used for statistical purposes.

Stillbirth is the intra-uterine death of a foetus of at least 26 weeks of gestation that showed no sign of life after complete birth.

Underlying cause of death (previously known as primary cause) is the disease or injury that initiated the sequence of events leading directly to death; or the circumstances of the accident or violence which produced the fatal injury. 


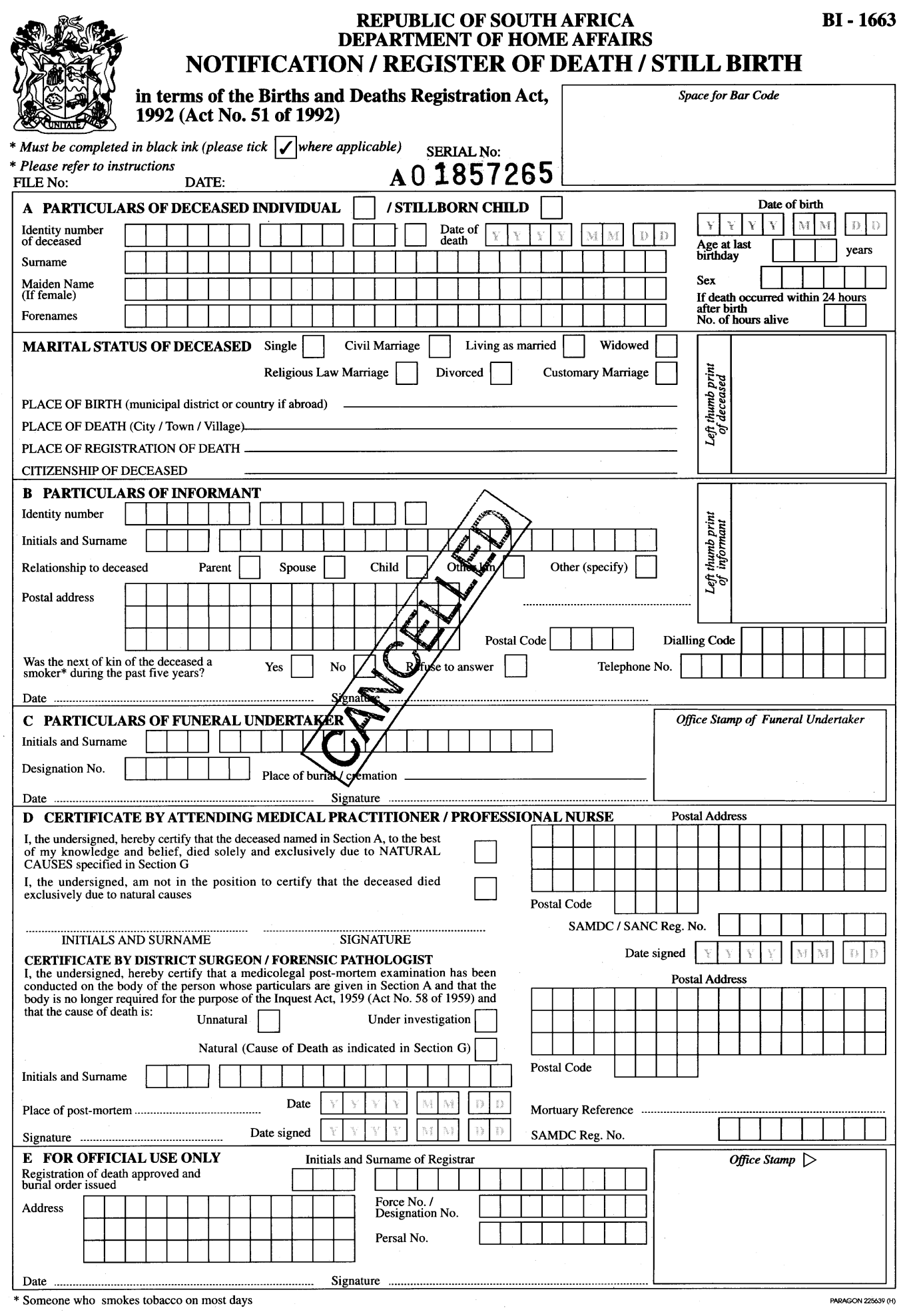


Appendix B: Reverse side of the death notification form

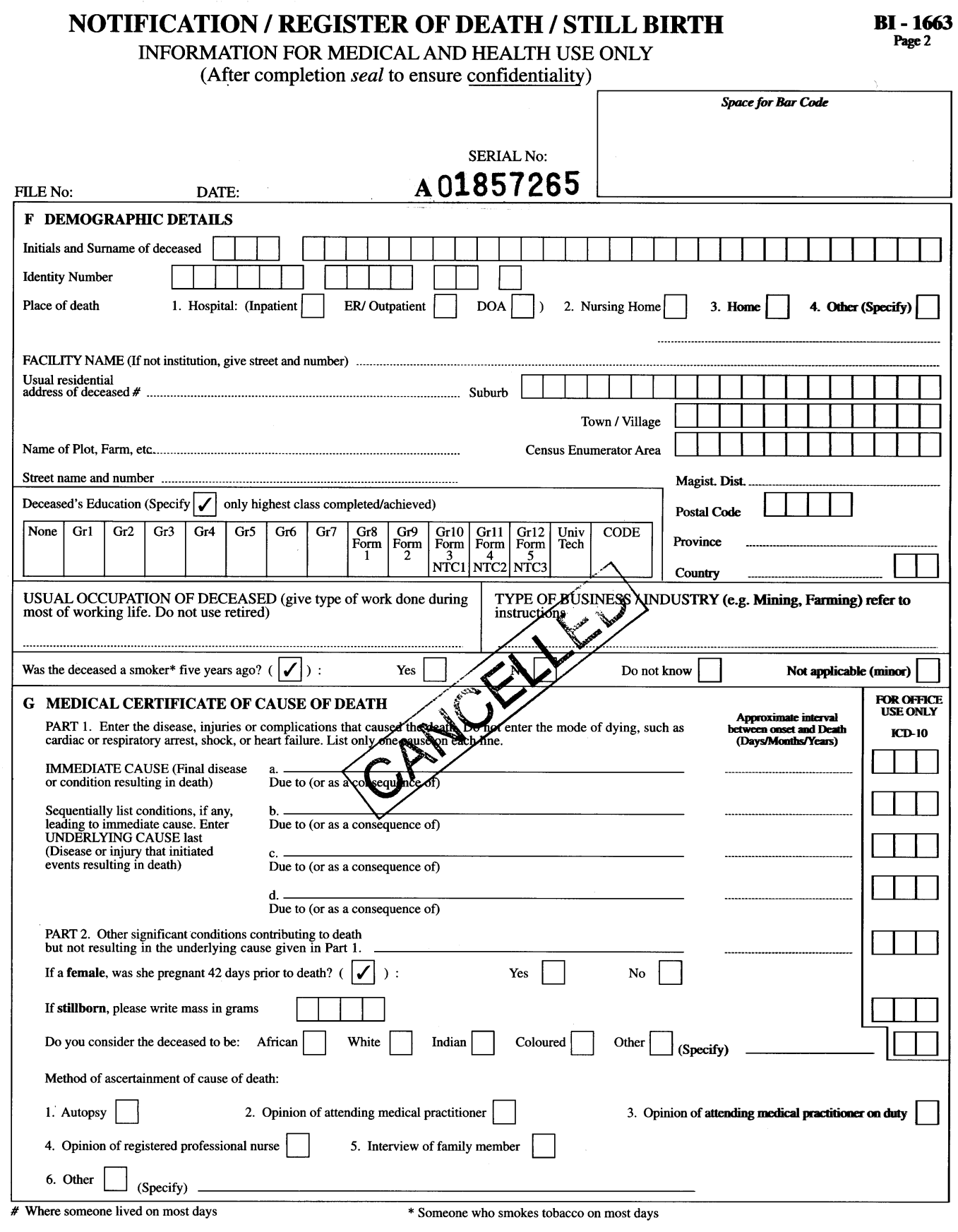


Appendix C: Number of deaths by age, sex and year of death, 1997-1999*

\begin{tabular}{|c|c|c|c|c|c|c|c|c|c|c|c|c|}
\hline \multirow[b]{2}{*}{ Age group } & \multicolumn{4}{|c|}{1997} & \multicolumn{4}{|c|}{1998} & \multicolumn{4}{|c|}{1999} \\
\hline & Male & Female & Unsp. & Total & Male & Female & Unsp. & Total & Male & Female & Unsp. & Total \\
\hline 0 & 12986 & 11546 & 202 & 24734 & 14926 & 13254 & 314 & 28494 & 14731 & 13455 & 438 & 28624 \\
\hline $1-4$ & 4049 & 3650 & 52 & 7751 & 4859 & 4485 & 96 & 9440 & 5068 & 4636 & 98 & 9802 \\
\hline $5-9$ & 1706 & 1252 & 17 & 2975 & 1779 & 1435 & 36 & 3250 & 1894 & 1505 & 34 & 3433 \\
\hline $10-14$ & 1546 & 1189 & 19 & 2754 & 1693 & 1288 & 23 & 3004 & 1649 & 1305 & 23 & 2977 \\
\hline $15-19$ & 3777 & 2475 & 23 & 6275 & 4105 & 2902 & 62 & 7069 & 4353 & 3325 & 88 & 7766 \\
\hline $20-24$ & 8175 & 5447 & 49 & 13671 & 8790 & 6902 & 109 & 15801 & 8637 & 8287 & 105 & 17029 \\
\hline $25-29$ & 10922 & 7427 & 43 & 18392 & 13075 & 9851 & 110 & 23036 & 13885 & 12606 & 141 & 26632 \\
\hline $30-34$ & 11830 & 7185 & 49 & 19064 & 14363 & 9701 & 126 & 24190 & 16288 & 12254 & 119 & 28661 \\
\hline $35-39$ & 11966 & 6855 & 51 & 18872 & 14603 & 8915 & 97 & 23615 & 16444 & 10802 & 111 & 27357 \\
\hline $40-44$ & 11778 & 6397 & 36 & 18211 & 13921 & 7920 & 94 & 21935 & 15201 & 8906 & 90 & 24197 \\
\hline $45-49$ & 12219 & 6362 & 50 & 18631 & 14182 & 7671 & 87 & 21940 & 14968 & 8511 & 98 & 23577 \\
\hline $50-54$ & 11288 & 6236 & 29 & 17553 & 12995 & 7205 & 79 & 20279 & 13862 & 7751 & 79 & 21692 \\
\hline $55-59$ & 12641 & 7923 & 45 & 20609 & 13920 & 8873 & 107 & 22900 & 14055 & 8672 & 84 & 22811 \\
\hline $60-64$ & 11183 & 9287 & 50 & 20520 & 12417 & 9993 & 59 & 22469 & 12677 & 10035 & 82 & 22794 \\
\hline $65-69$ & 12460 & 11037 & 45 & 23542 & 13236 & 12453 & 83 & 25772 & 12820 & 12311 & 91 & 25222 \\
\hline $70-74$ & 11285 & 10059 & 48 & 21392 & 12732 & 11790 & 53 & 24575 & 12852 & 12246 & 70 & 25168 \\
\hline $75-79$ & 11183 & 12332 & 44 & 23559 & 11412 & 12479 & 87 & 23978 & 10692 & 11583 & 63 & 22338 \\
\hline $80-84$ & 6599 & 8776 & 32 & 15407 & 7875 & 11042 & 48 & 18965 & 7600 & 11316 & 73 & 18989 \\
\hline $85-89$ & 3950 & 6916 & 25 & 10891 & 4257 & 7804 & 34 & 12095 & 4449 & 7942 & 51 & 12442 \\
\hline $90+$ & 2028 & 4730 & 13 & 6771 & 2363 & 5560 & 29 & 7952 & 2210 & 5380 & 30 & 7620 \\
\hline Unspecified & 3109 & 2362 & 106 & 5577 & 2821 & 2092 & 195 & 5108 & 1491 & 1108 & 109 & 2708 \\
\hline Total & 176680 & 139443 & 1028 & 317151 & 200324 & 163615 & 1928 & 365867 & 205826 & 173936 & 2077 & 381839 \\
\hline
\end{tabular}


Appendix C.1: Number of deaths by age, sex and year of death, 2000-2002*

\begin{tabular}{|c|c|c|c|c|c|c|c|c|c|c|c|c|}
\hline \multirow[b]{2}{*}{ Age group } & \multicolumn{4}{|c|}{2000} & \multicolumn{4}{|c|}{2001} & \multicolumn{4}{|c|}{2002} \\
\hline & Male & Female & Unsp. & Total & Male & Female & Unsp. & Total & Male & Female & Unsp. & Total \\
\hline 0 & 15000 & 13523 & 351 & 28874 & 15465 & 14070 & 307 & 29842 & 17866 & 16186 & 338 & 34390 \\
\hline $1-4$ & 5379 & 4917 & 86 & 10382 & 5876 & 5299 & 78 & 11253 & 6317 & 5676 & 87 & 12080 \\
\hline $5-9$ & 1997 & 1595 & 29 & 3621 & 2120 & 1706 & 28 & 3854 & 2400 & 1961 & 17 & 4378 \\
\hline $10-14$ & 1720 & 1337 & 36 & 3093 & 1746 & 1463 & 22 & 3231 & 1866 & 1484 & 24 & 3374 \\
\hline $15-19$ & 4318 & 3484 & 72 & 7874 & 4471 & 3903 & 62 & 8436 & 4735 & 4284 & 58 & 9077 \\
\hline $20-24$ & 8873 & 9865 & 84 & 18822 & 8934 & 10915 & 83 & 19932 & 9569 & 12475 & 109 & 22153 \\
\hline $25-29$ & 15068 & 15710 & 105 & 30883 & 16839 & 19269 & 108 & 36216 & 18627 & 23295 & 133 & 42055 \\
\hline $30-34$ & 18479 & 15797 & 108 & 34384 & 20896 & 18717 & 109 & 39722 & 23871 & 23512 & 145 & 47528 \\
\hline $35-39$ & 18544 & 13591 & 94 & 32229 & 21078 & 15852 & 100 & 37030 & 24066 & 19428 & 124 & 43618 \\
\hline $40-44$ & 17118 & 11006 & 77 & 28201 & 19326 & 12840 & 94 & 32260 & 21572 & 15482 & 113 & 37167 \\
\hline $45-49$ & 16113 & 9560 & 78 & 25751 & 17887 & 10934 & 62 & 28883 & 19285 & 12645 & 110 & 32040 \\
\hline $50-54$ & 15282 & 9094 & 64 & 24440 & 16885 & 10135 & 73 & 27093 & 18596 & 11244 & 102 & 29942 \\
\hline $55-59$ & 13925 & 8871 & 72 & 22868 & 14551 & 9124 & 65 & 23740 & 15398 & 10003 & 71 & 25472 \\
\hline $60-64$ & 14233 & 11254 & 66 & 25553 & 15102 & 12062 & 66 & 27230 & 16160 & 12699 & 79 & 28938 \\
\hline $65-69$ & 12584 & 12064 & 52 & 24700 & 13014 & 12793 & 64 & 25871 & 13739 & 13277 & 63 & 27079 \\
\hline $70-74$ & 13115 & 14136 & 67 & 27318 & 14037 & 15120 & 60 & 29217 & 13786 & 15469 & 62 & 29317 \\
\hline $75-79$ & 10351 & 11533 & 48 & 21932 & 10848 & 12036 & 61 & 22945 & 11091 & 12832 & 70 & 23993 \\
\hline $80-84$ & 8483 & 12638 & 31 & 21152 & 9162 & 13906 & 47 & 23115 & 9536 & 14188 & 60 & 23784 \\
\hline $85-89$ & 4681 & 8226 & 27 & 12934 & 4580 & 8358 & 31 & 12969 & 4373 & 8315 & 34 & 12722 \\
\hline $90+$ & 2530 & 6526 & 31 & 9087 & 3023 & 7157 & 28 & 10208 & 3294 & 7662 & 33 & 10989 \\
\hline Unspecified & 1185 & 890 & 143 & 2218 & 1044 & 782 & 98 & 1924 & 1137 & 788 & 112 & 2037 \\
\hline Total & 218978 & 195617 & 1721 & 416316 & 236884 & 216441 & 1646 & 454971 & 257284 & 242905 & 1944 & 502133 \\
\hline
\end{tabular}


Appendix C.2: Number of deaths by age, sex and year of death, 2003-2005*

\begin{tabular}{|c|c|c|c|c|c|c|c|c|c|c|c|c|}
\hline \multirow[b]{2}{*}{ Age group } & \multicolumn{4}{|c|}{2003} & \multicolumn{4}{|c|}{2004} & \multicolumn{4}{|c|}{2005} \\
\hline & Male & Female & Unsp. & Total & Male & Female & Unsp. & Total & Male & Female & Unsp. & Total \\
\hline 0 & 19945 & 18028 & 434 & 38407 & 21728 & 19164 & 530 & 41422 & 24037 & 21922 & 474 & 46433 \\
\hline $1-4$ & 7125 & 6276 & 78 & 13479 & 8250 & 7620 & 71 & 15941 & 8208 & 7310 & 80 & 15598 \\
\hline $5-9$ & 2776 & 2196 & 28 & 5000 & 3185 & 2799 & 13 & 5997 & 3358 & 2800 & 21 & 6179 \\
\hline $10-14$ & 2001 & 1641 & 25 & 3667 & 2138 & 1773 & 12 & 3923 & 2145 & 1855 & 17 & 4017 \\
\hline $15-19$ & 4836 & 4550 & 70 & 9456 & 4678 & 4610 & 40 & 9328 & 4768 & 4540 & 52 & 9360 \\
\hline $20-24$ & 10328 & 14165 & 104 & 24597 & 10362 & 15042 & 76 & 25480 & 10486 & 14850 & 89 & 25425 \\
\hline $25-29$ & 20004 & 26191 & 146 & 46341 & 19791 & 27518 & 110 & 47419 & 19307 & 27235 & 105 & 46647 \\
\hline $30-34$ & 27463 & 28098 & 139 & 55700 & 28419 & 30599 & 79 & 59097 & 28783 & 31230 & 105 & 60118 \\
\hline $35-39$ & 26414 & 22622 & 112 & 49148 & 28198 & 25121 & 86 & 53405 & 29397 & 26222 & 99 & 55718 \\
\hline $40-44$ & 24707 & 18405 & 116 & 43228 & 26438 & 20527 & 67 & 47032 & 27449 & 21465 & 83 & 48997 \\
\hline $45-49$ & 22017 & 14465 & 85 & 36567 & 23073 & 16228 & 64 & 39365 & 24416 & 17355 & 76 & 41847 \\
\hline $50-54$ & 20558 & 12870 & 67 & 33495 & 21091 & 14082 & 46 & 35219 & 21500 & 14946 & 57 & 36503 \\
\hline $55-59$ & 17180 & 10975 & 49 & 28204 & 18041 & 12010 & 32 & 30083 & 19686 & 13300 & 47 & 33033 \\
\hline $60-64$ & 17371 & 13290 & 56 & 30717 & 16948 & 13382 & 28 & 30358 & 16831 & 13239 & 34 & 30104 \\
\hline $65-69$ & 14651 & 13882 & 53 & 28586 & 15191 & 13788 & 25 & 29004 & 16362 & 15171 & 36 & 31569 \\
\hline $70-74$ & 14459 & 16364 & 55 & 30878 & 13428 & 15415 & 25 & 28868 & 12904 & 15077 & 33 & 28014 \\
\hline $75-79$ & 12060 & 14108 & 56 & 26224 & 11794 & 14066 & 15 & 25875 & 12208 & 15906 & 35 & 28149 \\
\hline $80-84$ & 9442 & 13695 & 39 & 23176 & 8639 & 11945 & 21 & 20605 & 8429 & 11828 & 21 & 20278 \\
\hline $85-89$ & 5435 & 10193 & 36 & 15664 & 5034 & 9472 & 19 & 14525 & 5444 & 10332 & 17 & 15793 \\
\hline $90+$ & 3380 & 8146 & 18 & 11544 & 3286 & 7473 & 14 & 10773 & 3285 & 7881 & 15 & 11181 \\
\hline Unspecified & 1657 & 940 & 207 & 2804 & 1920 & 928 & 242 & 3090 & 1975 & 1079 & 223 & 3277 \\
\hline Total & 283809 & 271100 & 1973 & 556882 & 291632 & 283562 & 1615 & 576809 & 300978 & 295543 & 1719 & 598240 \\
\hline
\end{tabular}

Data have been updated to include late registrations processed in 2010/11. 
Appendix C.3: Number of deaths by age, sex and year of death, 2006-2008*

\begin{tabular}{|c|c|c|c|c|c|c|c|c|c|c|c|c|}
\hline \multirow{2}{*}{ Age group } & \multicolumn{4}{|c|}{2006} & \multicolumn{4}{|c|}{2007} & \multicolumn{4}{|c|}{2008} \\
\hline & Male & Female & Unsp. & Total & Male & Female & Unsp. & Total & Male & Female & Unsp. & Total \\
\hline 0 & 25480 & 22074 & 725 & 48279 & 24801 & 21637 & 412 & 46850 & 24032 & 21342 & 288 & 45662 \\
\hline $1-4$ & 8384 & 7566 & 117 & 16067 & 7804 & 7009 & 47 & 14860 & 8189 & 7180 & 31 & 15400 \\
\hline $5-9$ & 3024 & 2547 & 17 & 5588 & 2864 & 2498 & 4 & 5366 & 2723 & 2295 & 6 & 5024 \\
\hline $10-14$ & 2385 & 1914 & 14 & 4313 & 2245 & 1901 & 2 & 4148 & 2225 & 1888 & 2 & 4115 \\
\hline $15-19$ & 4846 & 4595 & 38 & 9479 & 4879 & 4195 & 15 & 9089 & 4845 & 4121 & 26 & 8992 \\
\hline $20-24$ & 10865 & 14800 & 97 & 25762 & 10918 & 13731 & 49 & 24698 & 10703 & 12889 & 41 & 23633 \\
\hline $25-29$ & 19007 & 26145 & 82 & 45234 & 18498 & 24571 & 66 & 43135 & 18450 & 23517 & 42 & 42009 \\
\hline $30-34$ & 28879 & 31012 & 93 & 59984 & 28381 & 29114 & 65 & 57560 & 26798 & 27231 & 53 & 54082 \\
\hline $35-39$ & 29485 & 26093 & 77 & 55655 & 29406 & 24869 & 47 & 54322 & 29086 & 24353 & 46 & 53485 \\
\hline $40-44$ & 28108 & 21852 & 73 & 50033 & 27103 & 21205 & 45 & 48353 & 26071 & 20209 & 27 & 46307 \\
\hline $45-49$ & 25144 & 17953 & 45 & 43142 & 24871 & 17891 & 43 & 42805 & 24793 & 17534 & 30 & 42357 \\
\hline $50-54$ & 22797 & 15609 & 40 & 38446 & 22902 & 15650 & 17 & 38569 & 22735 & 15566 & 21 & 38322 \\
\hline $55-59$ & 20646 & 14185 & 40 & 34871 & 21432 & 14618 & 23 & 36073 & 21591 & 14937 & 19 & 36547 \\
\hline $60-64$ & 17067 & 13348 & 25 & 30440 & 17492 & 13483 & 10 & 30985 & 17743 & 13908 & 16 & 31667 \\
\hline $65-69$ & 17756 & 15816 & 24 & 33596 & 17953 & 15842 & 9 & 33804 & 18060 & 15605 & 10 & 33675 \\
\hline $70-74$ & 13594 & 15610 & 26 & 29230 & 13828 & 15835 & 8 & 29671 & 14151 & 15305 & 2 & 29458 \\
\hline $75-79$ & 12723 & 17020 & 24 & 29767 & 12591 & 17081 & 4 & 29676 & 12568 & 17194 & 4 & 29766 \\
\hline $80-84$ & 8949 & 12345 & 20 & 21314 & 8909 & 12927 & 2 & 21838 & 9026 & 13856 & 1 & 22883 \\
\hline $85-89$ & 6146 & 12031 & 11 & 18188 & 6362 & 12212 & 2 & 18576 & 5980 & 11198 & 1 & 17179 \\
\hline $90+$ & 3565 & 8714 & 9 & 12288 & 3683 & 8790 & 12 & 12485 & 3973 & 9547 & 27 & 13547 \\
\hline Unspecified & 864 & 356 & 144 & 1364 & 799 & 332 & 106 & 1237 & 664 & 245 & 133 & 1042 \\
\hline Total & 309714 & 301585 & 1741 & 613040 & 307721 & 295391 & 988 & 604100 & 304406 & 289920 & 826 & 595152 \\
\hline
\end{tabular}


Appendix C.4: Number of deaths by age, sex and year of death, 2009

\begin{tabular}{|l|r|r|r|r|}
\hline \multirow{2}{*}{ Age group } & \multicolumn{4}{|c|}{$\mathbf{2 0 0 9}$} \\
\cline { 2 - 5 } 0 & Male & Female & Unsp. & Total \\
\hline $1-4$ & 20348 & 17191 & 435 & 37974 \\
\hline $5-9$ & 6511 & 5959 & 27 & 12497 \\
\hline $10-14$ & 2309 & 1998 & 6 & 4313 \\
\hline $15-19$ & 2347 & 2046 & 4 & 4397 \\
\hline $20-24$ & 4598 & 4078 & 21 & 8697 \\
\hline $25-29$ & 9798 & 11591 & 45 & 21434 \\
\hline $30-34$ & 17376 & 21356 & 60 & 38792 \\
\hline $35-39$ & 24563 & 23810 & 73 & 48446 \\
\hline $40-44$ & 27259 & 22091 & 46 & 49396 \\
$45-49$ & 24784 & 18909 & 50 & 43743 \\
\hline $50-54$ & 24010 & 17097 & 40 & 41147 \\
\hline $55-59$ & 22529 & 15378 & 33 & 37940 \\
\hline $60-64$ & 21465 & 14935 & 26 & 36426 \\
\hline $65-69$ & 18951 & 14219 & 19 & 33189 \\
\hline $70-74$ & 17970 & 15526 & 11 & 33507 \\
\hline $75-79$ & 14990 & 15777 & 16 & 30783 \\
\hline $80-84$ & 12573 & 17587 & 7 & 30167 \\
\hline $85-89$ & 9662 & 14943 & 9 & 24614 \\
\hline $90+$ & 6070 & 11082 & 2 & 17154 \\
\hline Unspecified & 5196 & 11572 & 0 & 16768 \\
\hline Total & 858 & 308 & 123 & 1289 \\
\hline & 294167 & $\mathbf{2 7 7} 453$ & $\mathbf{1 0 5 3}$ & $\mathbf{5 7 2} 673$ \\
\hline
\end{tabular}


Appendix D: Year-to-year annual percentage changes in number of deaths by sex, 1997-2009*

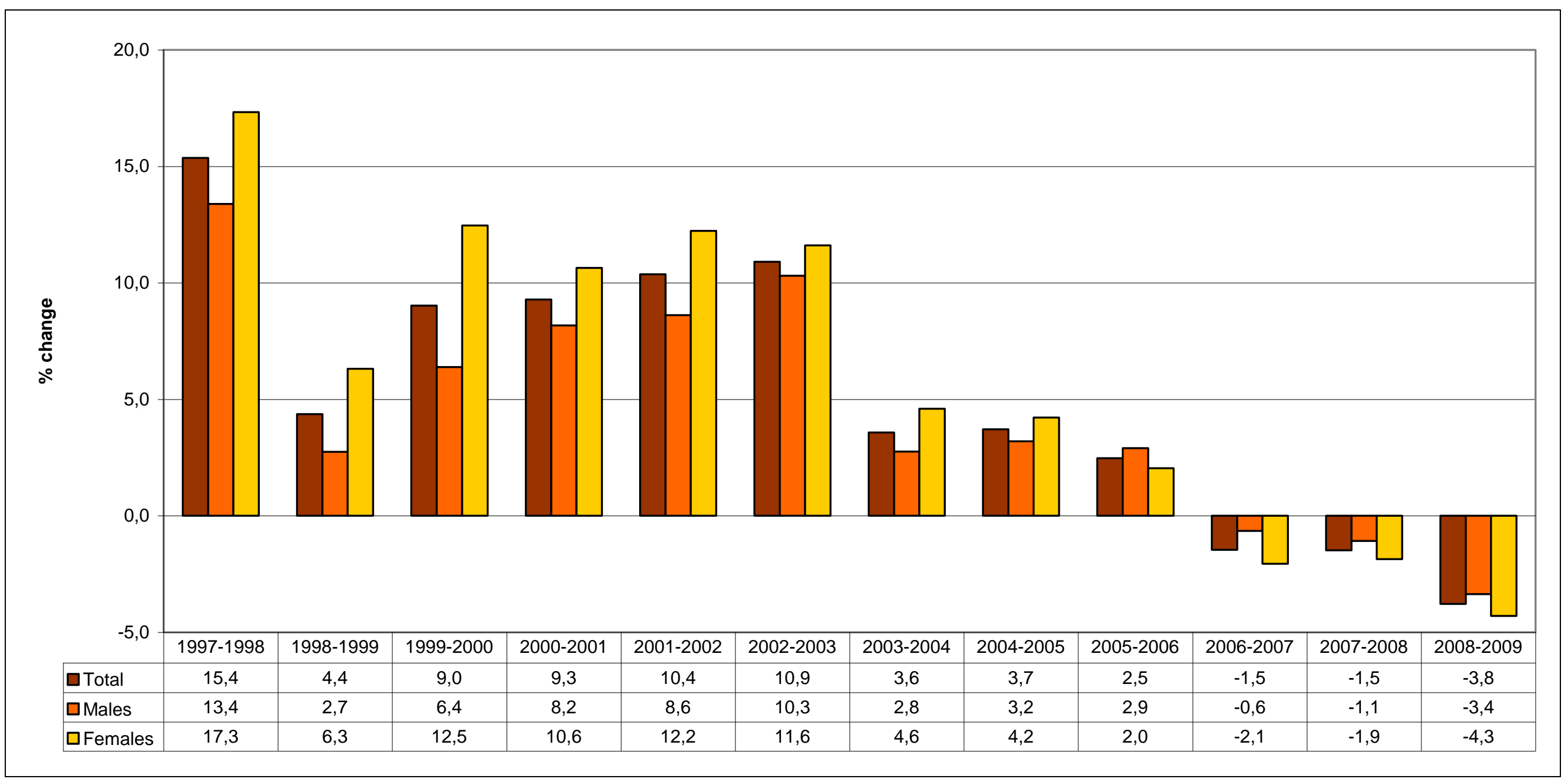

${ }^{*}$ Data for 1997-2008 have been updated to include late registrations processed in 2010/11. 


\section{Appendix E: Age specific death rates (ASDR) by year of death, 2005-2009*}

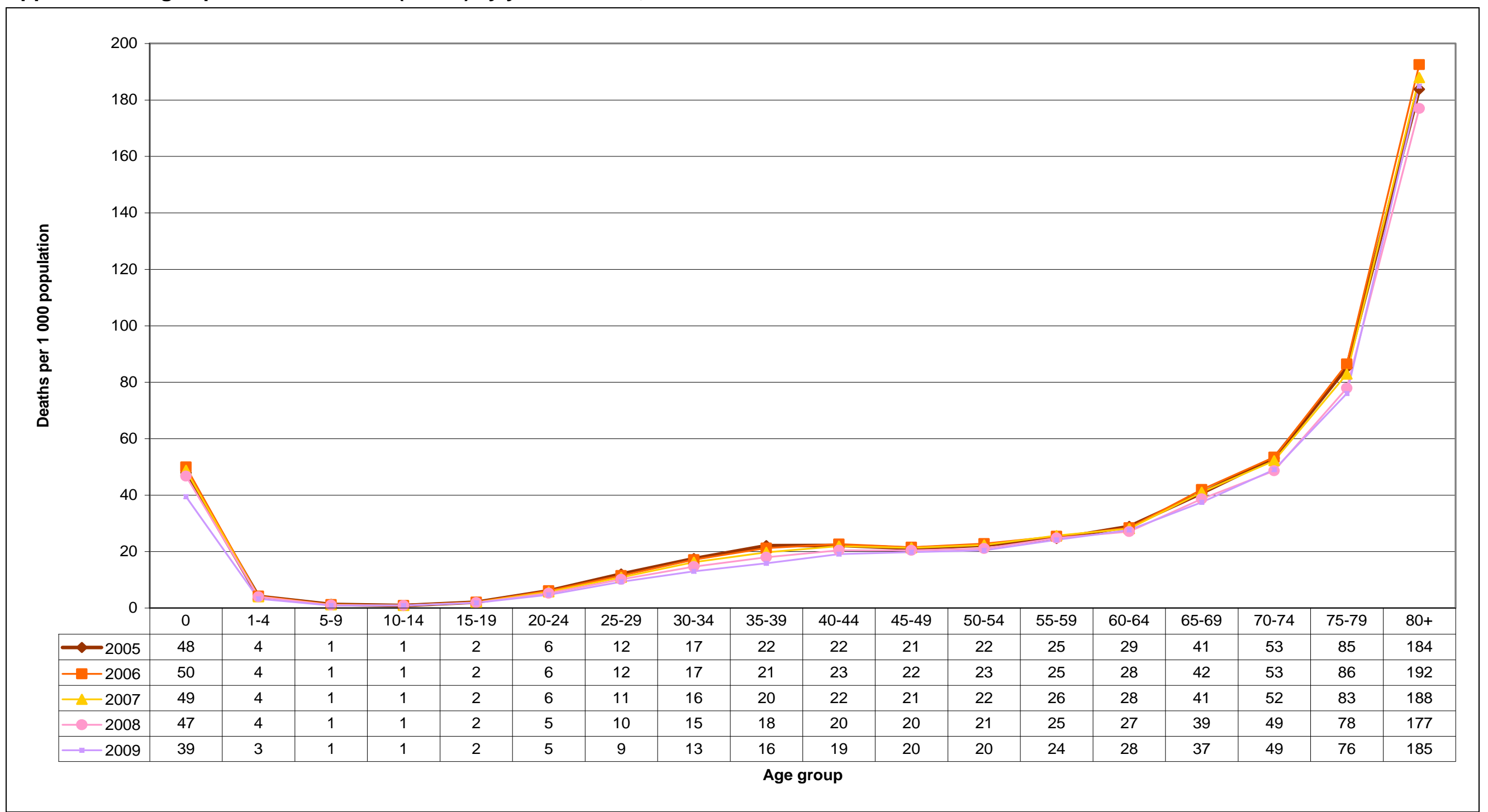

Data for 2005-2008 have been updated to include late registrations processed in 2010/11. All deaths adjusted for incompleteness of death registration. 


\section{Appendix F: Sex ratios at death by year of death, 1997-2009*}

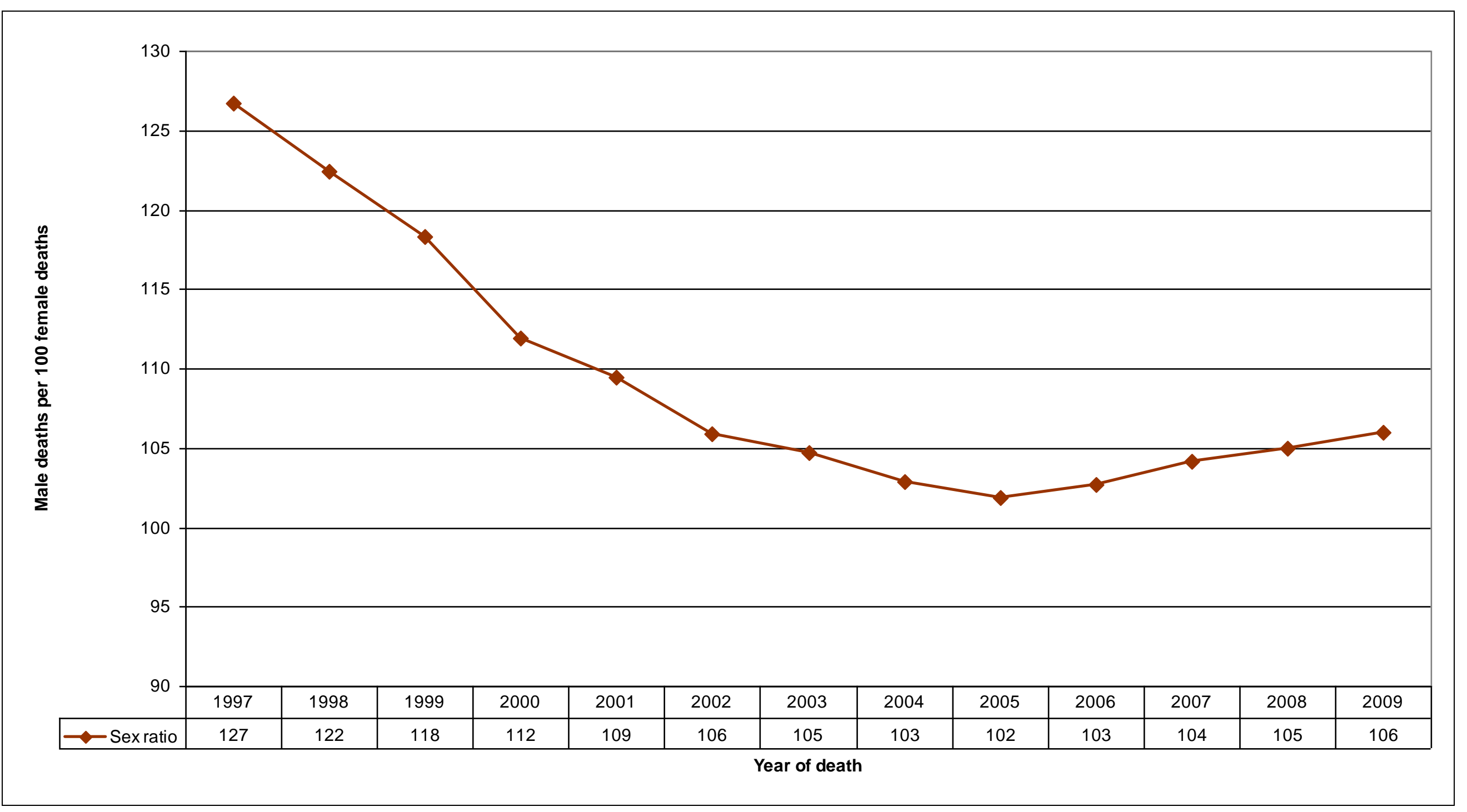

*Data for 1997-2008 have been updated to include late registrations processed in 2010/11. 
Appendix G: Number of deaths by province of death occurrence and province of usual residence of the deceased, 2009

\begin{tabular}{|c|c|c|c|c|c|c|c|c|c|c|c|c|}
\hline \multirow{2}{*}{$\begin{array}{l}\text { Province of } \\
\text { death }\end{array}$} & \multicolumn{11}{|c|}{ Province of usual residence } & \multirow[b]{2}{*}{ Total } \\
\hline & $\begin{array}{r}\text { Western } \\
\text { Cape } \\
\end{array}$ & $\begin{array}{r}\text { Eastern } \\
\text { Cape } \\
\end{array}$ & $\begin{array}{r}\text { Northern } \\
\text { Cape } \\
\end{array}$ & Free State & $\begin{array}{r}\text { KwaZulu- } \\
\text { Natal } \\
\end{array}$ & $\begin{array}{c}\text { North } \\
\text { West }\end{array}$ & Gauteng & $\begin{array}{r}\text { Mpu- } \\
\text { malanga }\end{array}$ & Limpopo & Foreign & Unspecified & \\
\hline Western Cape & 37315 & 370 & 163 & 62 & 465 & 98 & 217 & 36 & 100 & 62 & 6510 & 45398 \\
\hline Eastern Cape & 295 & 66951 & 57 & 95 & 1124 & 57 & 315 & 240 & 112 & 64 & 12822 & 82132 \\
\hline Northern Cape & 144 & 105 & 13479 & 98 & 46 & 272 & 74 & 12 & 70 & 9 & 773 & 15082 \\
\hline Free State & 40 & 215 & 209 & 44314 & 153 & 404 & 590 & 81 & 152 & 170 & 937 & 47265 \\
\hline KwaZulu-Natal & 186 & 1739 & 47 & 190 & 110080 & 70 & 447 & 422 & 122 & 96 & 13970 & 127369 \\
\hline North West & 48 & 111 & 356 & 290 & 57 & 31974 & 1284 & 128 & 291 & 81 & 5752 & 40372 \\
\hline Gauteng & 264 & 347 & 109 & 882 & 827 & 3193 & 96542 & 1879 & 1734 & 321 & 8631 & 114729 \\
\hline Mpumalanga & 29 & 133 & 31 & 111 & 403 & 121 & 1079 & 39710 & 972 & 167 & 2947 & 45703 \\
\hline Limpopo & 54 & 89 & 86 & 89 & 206 & 338 & 517 & 1012 & 45637 & 215 & 4664 & 52907 \\
\hline Foreign & 17 & 6 & 3 & 82 & 26 & 25 & 176 & 24 & 11 & 94 & 173 & 637 \\
\hline Unspecified & 36 & 65 & 15 & 51 & 206 & 87 & 113 & 148 & 176 & 4 & 178 & 1079 \\
\hline Total & 38428 & 70131 & 14555 & 46264 & 113593 & 36639 & 101354 & 43692 & 49377 & 1283 & 57357 & 572673 \\
\hline
\end{tabular}

Appendix G.1: Percentage distribution of deaths by province of death occurrence and province of usual residence of the deceased, 2009

\begin{tabular}{|c|c|c|c|c|c|c|c|c|c|c|c|c|}
\hline \multirow{2}{*}{$\begin{array}{l}\text { Province of } \\
\text { death }\end{array}$} & \multicolumn{11}{|c|}{ Province of usual residence } & \multirow[b]{2}{*}{ Total } \\
\hline & $\begin{array}{r}\text { Western } \\
\text { Cape } \\
\end{array}$ & $\begin{array}{r}\text { Eastern } \\
\text { Cape } \\
\end{array}$ & $\begin{array}{r}\text { Northern } \\
\text { Cape } \\
\end{array}$ & Free State & $\begin{array}{r}\text { KwaZulu- } \\
\text { Natal } \\
\end{array}$ & $\begin{array}{l}\text { North } \\
\text { West } \\
\end{array}$ & Gauteng & $\begin{array}{r}\text { Mpu- } \\
\text { malanga }\end{array}$ & Limpopo & Foreign & Unspecified & \\
\hline Western Cape & 82,2 & 0,8 & 0,4 & 0,1 & 1,0 & 0,2 & 0,5 & 0,1 & 0,2 & 0,1 & 14,3 & 100,0 \\
\hline Eastern Cape & 0,4 & 81,5 & 0,1 & 0,1 & 1,4 & 0,1 & 0,4 & 0,3 & 0,1 & 0,1 & 15,6 & 100,0 \\
\hline Northern Cape & 1,0 & 0,7 & 89,4 & 0,6 & 0,3 & 1,8 & 0,5 & 0,1 & 0,5 & 0,1 & 5,1 & 100,0 \\
\hline Free State & 0,1 & 0,5 & 0,4 & 93,8 & 0,3 & 0,9 & 1,2 & 0,2 & 0,3 & 0,4 & 2,0 & 100,0 \\
\hline KwaZulu-Natal & 0,1 & 1,4 & 0,0 & 0,1 & 86,4 & 0,1 & 0,4 & 0,3 & 0,1 & 0,1 & 11,0 & 100,0 \\
\hline North West & 0,1 & 0,3 & 0,9 & 0,7 & 0,1 & 79,2 & 3,2 & 0,3 & 0,7 & 0,2 & 14,2 & 100,0 \\
\hline Gauteng & 0,2 & 0,3 & 0,1 & 0,8 & 0,7 & 2,8 & 84,1 & 1,6 & 1,5 & 0,3 & 7,5 & 100,0 \\
\hline Mpumalanga & 0,1 & 0,3 & 0,1 & 0,2 & 0,9 & 0,3 & 2,4 & 86,9 & 2,1 & 0,4 & 6,4 & 100,0 \\
\hline Limpopo & 0,1 & 0,2 & 0,2 & 0,2 & 0,4 & 0,6 & 1,0 & 1,9 & 86,3 & 0,4 & 8,8 & 100,0 \\
\hline Foreign & 2,7 & 0,9 & 0,5 & 12,9 & 4,1 & 3,9 & 27,6 & 3,8 & 1,7 & 14,8 & 27,2 & 100,0 \\
\hline Unspecified & 3,3 & 6,0 & 1,4 & 4,7 & 19,1 & 8,1 & 10,5 & 13,7 & 16,3 & 0,4 & 16,5 & 100,0 \\
\hline
\end{tabular}


Appendix H: Number of deaths by age, province and district municipality of death occurrence, 2009*

\begin{tabular}{|c|c|c|c|c|c|c|c|c|c|}
\hline \multirow{2}{*}{$\begin{array}{l}\text { Province of } \\
\text { death } \\
\text { occurrence }\end{array}$} & \multirow{2}{*}{$\begin{array}{l}\text { District municipality of } \\
\text { death occurrence }\end{array}$} & \multicolumn{8}{|c|}{ Age } \\
\hline & & 0 & $1-4$ & $5-14$ & $15-49$ & $50-64$ & $65+$ & Unsp. & Total \\
\hline \multirow{8}{*}{ Western Cape } & Cape Winelands & 336 & 79 & 49 & 2102 & 1629 & 2138 & 7 & 6340 \\
\hline & Central Karoo & 48 & 13 & 5 & 319 & 208 & 269 & 0 & 862 \\
\hline & City of Cape Town Metro & 1591 & 331 & 232 & 9870 & 6101 & 10369 & 43 & 28537 \\
\hline & Eden & 235 & 46 & 39 & 1572 & 1174 & 1981 & 10 & 5057 \\
\hline & Overberg & 79 & 14 & 10 & 496 & 371 & 719 & 2 & 1691 \\
\hline & West Coast & 139 & 20 & 22 & 991 & 718 & 1003 & 5 & 2898 \\
\hline & Unspecified & 3 & 1 & 0 & 4 & 3 & 2 & 0 & 13 \\
\hline & Total & 2431 & 504 & 357 & 15354 & 10204 & 16481 & 67 & 45398 \\
\hline \multirow{10}{*}{ Eastern Cape } & Alfred Nzo & 272 & 215 & 213 & 4581 & 1511 & 2675 & 7 & 9474 \\
\hline & Amathole & 479 & 253 & 232 & 6322 & 2778 & 5481 & 16 & 15561 \\
\hline & Buffalo City Metro & 422 & 165 & 119 & 4941 & 2461 & 3620 & 27 & 11755 \\
\hline & Cacadu & 271 & 72 & 43 & 1874 & 1073 & 1538 & 2 & 4873 \\
\hline & Chris Hani & 350 & 155 & 98 & 3872 & 1817 & 3109 & 9 & 9410 \\
\hline & Joe Gqabi & 227 & 106 & 76 & 2365 & 1012 & 1755 & 1 & 5542 \\
\hline & Nelson Mandela Bay Metro & 624 & 211 & 130 & 5773 & 3271 & 4035 & 8 & 14052 \\
\hline & O.R.Tambo & 265 & 244 & 248 & 5568 & 1870 & 3235 & 22 & 11452 \\
\hline & Unspecified & 1 & 2 & 0 & 6 & 3 & 1 & 0 & 13 \\
\hline & Total & 2911 & 1423 & 1159 & 35302 & 15796 & 25449 & 92 & 82132 \\
\hline \multirow{6}{*}{ Northern Cape } & Frances Baard & 281 & 110 & 50 & 1927 & 1008 & 1110 & 1 & 4487 \\
\hline & John Taolo Gaetsewe & 281 & 82 & 25 & 1221 & 499 & 635 & 1 & 2744 \\
\hline & Namakwa & 41 & 10 & 9 & 330 & 240 & 469 & 0 & 1099 \\
\hline & Pixley ka Seme & 226 & 55 & 23 & 1058 & 576 & 703 & 0 & 2641 \\
\hline & Siyanda & 251 & 92 & 59 & 1686 & 847 & 1168 & 8 & 4111 \\
\hline & Total & 1080 & 349 & 166 & 6222 & 3170 & 4085 & 10 & 15082 \\
\hline \multirow{7}{*}{ Free State } & Fezile Dabi & 558 & 162 & 77 & 3096 & 1455 & 1809 & 2 & 7159 \\
\hline & Lejweleputswa & 1011 & 287 & 132 & 5597 & 2159 & 2150 & 40 & 11376 \\
\hline & Mangaung Metro & 875 & 232 & 158 & 6190 & 2687 & 3186 & 3 & 13331 \\
\hline & Thabo Mofutsanyane & 1186 & 325 & 205 & 6159 & 2419 & 2869 & 16 & 13179 \\
\hline & Xhariep & 168 & 40 & 22 & 924 & 487 & 575 & 0 & 2216 \\
\hline & Unspecified & 2 & 0 & 0 & 2 & 0 & 0 & 0 & 4 \\
\hline & Total & 3800 & 1046 & 594 & 21968 & 9207 & 10589 & 61 & 47265 \\
\hline \multirow{13}{*}{ KwaZulu-Natal } & Amajuba & 443 & 140 & 117 & 3307 & 1189 & 1379 & 29 & 6604 \\
\hline & eThekwini Metro & 2044 & 691 & 792 & 18839 & 7267 & 9581 & 151 & 39365 \\
\hline & iLembe & 405 & 152 & 166 & 3280 & 1156 & 1521 & 40 & 6720 \\
\hline & Sisonke & 283 & 108 & 102 & 2185 & 760 & 1158 & 7 & 4603 \\
\hline & Ugu & 663 & 262 & 281 & 5718 & 1946 & 3084 & 35 & 11989 \\
\hline & UMgungundlovu & 524 & 179 & 247 & 6811 & 2567 & 3482 & 9 & 13819 \\
\hline & Umkhanyakude & 395 & 137 & 167 & 3070 & 995 & 1571 & 21 & 6356 \\
\hline & Umzinyathi & 435 & 147 & 135 & 2866 & 1037 & 1562 & 26 & 6208 \\
\hline & Uthukela & 592 & 198 & 162 & 4383 & 1530 & 1924 & 12 & 8801 \\
\hline & Uthungulu & 951 & 246 & 237 & 5855 & 1821 & 2382 & 83 & 11575 \\
\hline & Zululand & 792 & 256 & 176 & 4487 & 1414 & 1790 & 23 & 8938 \\
\hline & Unspecified & 204 & 80 & 51 & 1147 & 355 & 552 & 2 & 2391 \\
\hline & Total & 7731 & 2596 & 2633 & 61948 & 22037 & 29986 & 438 & 127369 \\
\hline
\end{tabular}


Appendix H: Number of deaths by age, province and district municipality of death occurrence, 2009* (concluded)

\begin{tabular}{|c|c|c|c|c|c|c|c|c|c|}
\hline \multirow{2}{*}{$\begin{array}{l}\text { Province of } \\
\text { death } \\
\text { occurrence }\end{array}$} & \multirow{2}{*}{$\begin{array}{l}\text { District municipality of } \\
\text { death occurrence }\end{array}$} & \multicolumn{8}{|c|}{ Age } \\
\hline & & 0 & $1-4$ & $5-14$ & $15-49$ & $50-64$ & $65+$ & Unsp. & Total \\
\hline \multirow{6}{*}{ North West } & Bojanala & 1189 & 387 & 167 & 5888 & 2643 & 3501 & 45 & 13820 \\
\hline & Dr Kenneth Kaunda & 875 & 191 & 101 & 4028 & 1845 & 2202 & 20 & 9262 \\
\hline & Dr Ruth Segomotsi Mompati & 681 & 258 & 86 & 2617 & 1170 & 1687 & 3 & 6502 \\
\hline & Ngaka Modiri Molema & 1056 & 320 & 139 & 4588 & 1936 & 2730 & 8 & 10777 \\
\hline & Unspecified & 1 & 0 & 0 & 6 & 1 & 3 & 0 & 11 \\
\hline & Total & 3802 & 1156 & 493 & 17127 & 7595 & 10123 & 76 & 40372 \\
\hline \multirow{7}{*}{ Gauteng } & City of Johannesburg Metro & 2709 & 681 & 437 & 15976 & 6988 & 9937 & 229 & 36957 \\
\hline & City of Tshwane Metro & 1779 & 617 & 391 & 10505 & 5241 & 8149 & 12 & 26694 \\
\hline & Ekurhuleni Metro & 3065 & 704 & 390 & 14128 & 5718 & 6527 & 39 & 30571 \\
\hline & Sedibeng & 891 & 196 & 134 & 4440 & 2271 & 2651 & 25 & 10608 \\
\hline & West Rand & 899 & 231 & 129 & 4558 & 1949 & 2072 & 25 & 9863 \\
\hline & Unspecified & 4 & 0 & 0 & 19 & 5 & 8 & 0 & 36 \\
\hline & Total & 9347 & 2429 & 1481 & 49626 & 22172 & 29344 & 330 & 114729 \\
\hline \multirow{5}{*}{ Mpumalanga } & Ehlanzeni & 946 & 545 & 448 & 9407 & 3225 & 4176 & 83 & 18830 \\
\hline & Gert Sibande & 1320 & 333 & 228 & 6960 & 2586 & 2788 & 23 & 14238 \\
\hline & Nkangala & 807 & 293 & 210 & 5842 & 2467 & 2953 & 37 & 12609 \\
\hline & Unspecified & 0 & 0 & 0 & 16 & 6 & 4 & 0 & 26 \\
\hline & Total & 3073 & 1171 & 886 & 22225 & 8284 & 9921 & 143 & 45703 \\
\hline \multirow{7}{*}{ Limpopo } & Capricorn & 1053 & 471 & 258 & 5987 & 2589 & 4697 & 4 & 15059 \\
\hline & Greater Sekhukhune & 665 & 355 & 206 & 4774 & 1846 & 3652 & 2 & 11500 \\
\hline & Mopani & 868 & 464 & 187 & 4568 & 1805 & 3229 & 22 & 11143 \\
\hline & Vhembe & 669 & 348 & 178 & 3530 & 1672 & 3520 & 26 & 9943 \\
\hline & Waterberg & 437 & 158 & 90 & 2205 & 877 & 1475 & 2 & 5244 \\
\hline & Unspecified & 1 & 0 & 0 & 7 & 2 & 8 & 0 & 18 \\
\hline & Total & 3693 & 1796 & 919 & 21071 & 8791 & 16581 & 56 & 52907 \\
\hline Foreign & Total & 7 & 4 & 5 & 341 & 120 & 159 & 1 & 637 \\
\hline
\end{tabular}

${ }^{*}$ Excluding 1079 deaths with unspecified province of death occurrence 
Appendix I: Number of deaths by sex, province and district municipality of death occurrence, 2009*

\begin{tabular}{|c|c|c|c|c|c|c|}
\hline \multirow{2}{*}{$\begin{array}{l}\text { Province of death } \\
\text { occurrence }\end{array}$} & \multirow{2}{*}{$\begin{array}{l}\text { District municipality of death } \\
\text { occurrence }\end{array}$} & \multicolumn{4}{|c|}{ Sex } & \multirow{2}{*}{ Sex ratio } \\
\hline & & Male & Female & Unspecified & Total & \\
\hline \multirow{8}{*}{ Western Cape } & Cape Winelands & 3508 & 2818 & 14 & 6340 & 124 \\
\hline & Central Karoo & 483 & 378 & 1 & 862 & 128 \\
\hline & City of Cape Town Metro & 15323 & 13155 & 59 & 28537 & 116 \\
\hline & Eden & 2785 & 2265 & 7 & 5057 & 123 \\
\hline & Overberg & 985 & 704 & 2 & 1691 & 140 \\
\hline & West Coast & 1633 & 1262 & 3 & 2898 & 129 \\
\hline & Unspecified & 6 & 7 & 0 & 13 & 86 \\
\hline & Total & 24723 & 20589 & 86 & 45398 & 120 \\
\hline \multirow{10}{*}{ Eastern Cape } & Alfred Nzo & 4566 & 4894 & 14 & 9474 & 93 \\
\hline & Amathole & 7609 & 7941 & 11 & 15561 & 96 \\
\hline & Buffalo City Metro & 6010 & 5732 & 13 & 11755 & 105 \\
\hline & Cacadu & 2495 & 2364 & 14 & 4873 & 106 \\
\hline & Chris Hani & 4639 & 4760 & 11 & 9410 & 97 \\
\hline & Joe Gqabi & 2691 & 2843 & 8 & 5542 & 95 \\
\hline & Nelson Mandela Bay Metro & 7334 & 6704 & 14 & 14052 & 109 \\
\hline & O.R.Tambo & 5600 & 5837 & 15 & 11452 & 96 \\
\hline & Unspecified & 7 & 6 & 0 & 13 & 117 \\
\hline & Total & 40951 & 41081 & 100 & 82132 & 100 \\
\hline \multirow{6}{*}{ Northern Cape } & Frances Baard & 2357 & 2120 & 10 & 4487 & 111 \\
\hline & John Taolo Gaetsewe & 1404 & 1340 & 0 & 2744 & 105 \\
\hline & Namakwa & 626 & 472 & 1 & 1099 & 133 \\
\hline & Pixley ka Seme & 1341 & 1296 & 4 & 2641 & 103 \\
\hline & Siyanda & 2131 & 1976 & 4 & 4111 & 108 \\
\hline & Total & 7859 & 7204 & 19 & 15082 & 109 \\
\hline \multirow{7}{*}{ Free State } & Fezile Dabi & 3751 & 3406 & 2 & 7159 & 110 \\
\hline & Lejweleputswa & 5938 & 5425 & 13 & 11376 & 109 \\
\hline & Mangaung Metro & 6823 & 6495 & 13 & 13331 & 105 \\
\hline & Thabo Mofutsanyane & 6617 & 6553 & 9 & 13179 & 101 \\
\hline & Xhariep & 1087 & 1128 & 1 & 2216 & 96 \\
\hline & Unspecified & 3 & 1 & 0 & 4 & 300 \\
\hline & Total & 24219 & 23008 & 38 & 47265 & 105 \\
\hline \multirow{13}{*}{ KwaZulu-Natal } & Amajuba & 3310 & 3281 & 13 & 6604 & 101 \\
\hline & eThekwini Metro & 20092 & 19240 & 33 & 39365 & 104 \\
\hline & iLembe & 3453 & 3260 & 7 & 6720 & 106 \\
\hline & Sisonke & 2254 & 2339 & 10 & 4603 & 96 \\
\hline & Ugu & 6030 & 5948 & 11 & 11989 & 101 \\
\hline & UMgungundlovu & 6893 & 6904 & 22 & 13819 & 100 \\
\hline & Umkhanyakude & 3155 & 3193 & 8 & 6356 & 99 \\
\hline & Umzinyathi & 3071 & 3127 & 10 & 6208 & 98 \\
\hline & Uthukela & 4555 & 4235 & 11 & 8801 & 108 \\
\hline & Uthungulu & 5781 & 5770 & 24 & 11575 & 100 \\
\hline & Zululand & 4445 & 4471 & 22 & 8938 & 99 \\
\hline & Unspecified & 1135 & 1247 & 9 & 2391 & 91 \\
\hline & Total & 64174 & 63015 & 180 & 127369 & 102 \\
\hline
\end{tabular}

${ }^{*}$ Excluding 1079 deaths with unspecified province of death occurrence

2 Male deaths per 100 female deaths 


\section{Appendix I: Number of deaths by sex, province and district municipality of death occurrence,} 2009* (concluded)

\begin{tabular}{|c|c|c|c|c|c|c|}
\hline \multirow{2}{*}{$\begin{array}{l}\text { Province of death } \\
\text { occurrence }\end{array}$} & \multirow{2}{*}{$\begin{array}{l}\text { District municipality of death } \\
\text { occurrence }\end{array}$} & \multicolumn{4}{|c|}{ Sex } & \multirow{2}{*}{ Sex ratio } \\
\hline & & Male & Female & Unspecified & Total & \\
\hline \multirow{6}{*}{ North West } & Bojanala & 7456 & 6329 & 35 & 13820 & 118 \\
\hline & Dr Kenneth Kaunda & 4945 & 4291 & 26 & 9262 & 115 \\
\hline & Dr Ruth Segomotsi Mompati & 3279 & 3210 & 13 & 6502 & 102 \\
\hline & Ngaka Modiri Molema & 5597 & 5164 & 16 & 10777 & 108 \\
\hline & Unspecified & 6 & 5 & 0 & 11 & 120 \\
\hline & Total & 21283 & 18999 & 90 & 40372 & 112 \\
\hline \multirow{7}{*}{ Gauteng } & City of Johannesburg Metro & 19388 & 17357 & 212 & 36957 & 112 \\
\hline & City of Tshwane Metro & 14078 & 12569 & 47 & 26694 & 112 \\
\hline & Ekurhuleni Metro & 16120 & 14377 & 74 & 30571 & 112 \\
\hline & Sedibeng & 5503 & 5090 & 15 & 10608 & 108 \\
\hline & West Rand & 5367 & 4472 & 24 & 9863 & 120 \\
\hline & Unspecified & 15 & 21 & 0 & 36 & 71 \\
\hline & Total & 60471 & 53886 & 372 & 114729 & 112 \\
\hline \multirow{5}{*}{ Mpumalanga } & Ehlanzeni & 9677 & 9105 & 48 & 18830 & 106 \\
\hline & Gert Sibande & 7201 & 7015 & 22 & 14238 & 103 \\
\hline & Nkangala & 6568 & 6016 & 25 & 12609 & 109 \\
\hline & Unspecified & 19 & 7 & 0 & 26 & 271 \\
\hline & Total & 23465 & 22143 & 95 & 45703 & 106 \\
\hline \multirow{7}{*}{ Limpopo } & Capricorn & 7498 & 7540 & 21 & 15059 & 99 \\
\hline & Greater Sekhukhune & 5453 & 6031 & 16 & 11500 & 90 \\
\hline & Mopani & 5461 & 5671 & 11 & 11143 & 96 \\
\hline & Vhembe & 4899 & 5029 & 15 & 9943 & 97 \\
\hline & Waterberg & 2726 & 2514 & 4 & 5244 & 108 \\
\hline & Unspecified & 8 & 10 & 0 & 18 & 80 \\
\hline & Total & 26045 & 26795 & 67 & 52907 & 97 \\
\hline Foreign & Total & 426 & 211 & & 637 & 202 \\
\hline
\end{tabular}

${ }^{*}$ Excluding 1079 deaths with unspecified province of death occurrence

\footnotetext{
${ }^{3}$ Male deaths per 100 female deaths
} 
Appendix J: All underlying causes of death, 2009

\begin{tabular}{|c|c|c|}
\hline Causes of death (based on the 10th revision, International Classification of Diseases, 1992) & Number & Percent \\
\hline All causes & 572673 & 100,0 \\
\hline III-defined and unknown causes of mortality (R95-R99) & 72887 & 12,7 \\
\hline Tuberculosis (A15-A19) & 69003 & 12,0 \\
\hline Influenza and pneumonia (J09-J18) & 42964 & 7,5 \\
\hline Other external causes of accidental injury (W00-X59) & 31166 & 5,4 \\
\hline Intestinal infectious diseases (A00-A09) & 30675 & 5,4 \\
\hline Other forms of heart disease (I30-I52) & 26462 & 4,6 \\
\hline Cerebrovascular diseases (160-169) & 24835 & 4,3 \\
\hline Diabetes mellitus (E10-E14) & 20523 & 3,6 \\
\hline Human immunodeficiency virus [HIV] disease (B20-B24) & 17570 & 3,1 \\
\hline Hypertensive diseases (I10-I15) & 15386 & 2,7 \\
\hline Chronic lower respiratory diseases (J40-J47) & 14184 & 2,5 \\
\hline Certain disorders involving the immune mechanism (D80-D89) & 13096 & 2,3 \\
\hline Ischaemic heart diseases (I20-I25) & 12291 & 2,1 \\
\hline Other viral diseases (B25-B34) & 11564 & 2,0 \\
\hline Malignant neoplasm of digestive organs (C15-C26) & 9430 & 1,6 \\
\hline Inflammatory diseases of the central nervous system (G00-G09) & 7903 & 1,4 \\
\hline Other acute lower respiratory infections (J20-J22) & 7874 & 1,4 \\
\hline Renal failure (N17-N19) & 6703 & 1,2 \\
\hline Event of undetermined intent (Y10-Y34) & 6683 & 1,2 \\
\hline Respiratory and cardiovascular disorders specific to the perinatal period (P20-P29) & 5765 & 1,0 \\
\hline Other bacterial diseases (A30-A49) & 5689 & 1,0 \\
\hline Transport accidents (V01-V99) & 5674 & 1,0 \\
\hline Diseases of liver (K70-K77) & 5301 & 0,9 \\
\hline Malignant neoplasm of respiratory and intrathoracic organs (C30-39) & 5285 & 0,9 \\
\hline Assault (X85-Y09) & 5089 & 0,9 \\
\hline Other diseases of the respiratory system (J95-J99) & 5015 & 0,9 \\
\hline Malignant neoplasm of female genital organs (C51-C58) & 4229 & 0,7 \\
\hline General symptoms and signs (R50-R69) & 4191 & 0,7 \\
\hline Protozoal diseases (B50-B64) & 4008 & 0,7 \\
\hline Metabolic disorders (E70-E90) & 3943 & 0,7 \\
\hline Episodic and paroxysmal disorders (G40-G47) & 3760 & 0,7 \\
\hline Aplastic and other anaemias (D60-D64) & 3094 & 0,5 \\
\hline Malignant neoplasms of ill-defined, secondary \& unspecified sites (C76-C80) & 3058 & 0,5 \\
\hline Mycoses (B35-B49) & 2837 & 0,5 \\
\hline Malignant neoplasm of breast (C50) & 2753 & 0,5 \\
\hline Pulmonary heart disease and diseases of pulmonary circulation (I26-I28) & 2676 & 0,5 \\
\hline Other respiratory diseases principally affecting the interstitium (J80-J84) & 2636 & 0,5 \\
\hline Malignant neoplasms stated or presumed primary of lymphoid, haematopoietic \& related tissue (C81-C96) & 2569 & 0,4 \\
\hline Malnutrition (E40-E46) & 2529 & 0,4 \\
\hline Diseases of oesophagus, stomach and duodenum (K20-K31) & 2505 & 0,4 \\
\hline Malignant neoplasm of male genital organs (C60-C63) & 2414 & 0,4 \\
\hline Noninfective enteritis and colitis (K50-K52) & 2341 & 0,4 \\
\hline Other disorders of glucose regulation and pancreatic internal secretion (E15-E16) & 1847 & 0,3 \\
\hline Disorders related to length of gestation and fetal growth (P05-P08) & 1729 & 0,3 \\
\hline Other diseases of intestines (K55-K63) & 1569 & 0,3 \\
\hline Other disorders originating in the perinatal period (P90-P96) & 1565 & 0,3 \\
\hline Diseases of arteries, arterioles and capillaries (170-179) & 1550 & 0,3 \\
\hline Infections specific to the perinatal period (P35-P39) & 1412 & 0,2 \\
\hline Malignant neoplasm of mesothelial and soft tissue (C45-C49) & 1341 & 0,2 \\
\hline Lung diseases due to external agents (J60-J70) & 1270 & 0,2 \\
\hline
\end{tabular}


Appendix J: All underlying causes of death, 2009 (continued)

\begin{tabular}{|c|c|c|}
\hline Causes of death (based on the 10th revision, International Classification of Diseases, 1992) & Number & Percent \\
\hline All causes & 572673 & 100,0 \\
\hline Other disorders of the nervous system (G90-G99) & 1108 & 0,2 \\
\hline Other diseases of the digestive system (K90-K93) & 1084 & 0,2 \\
\hline Organic, including symptomatic, mental disorders (F00-F09) & 1049 & 0,2 \\
\hline Neoplasms of uncertain or unknown behaviour (D37-D48) & 1035 & 0,2 \\
\hline Malignant neoplasm of lip, oral caity and pharynx (C00-C14) & 1026 & 0,2 \\
\hline Disorders of gallbladder, biliary tract and pancreas (K80-K87) & 1009 & 0,2 \\
\hline $\begin{array}{l}\text { Fetus and newborn affected by maternal factors and by complications of pregnancy, labour and delivery } \\
\text { (P00-P04) }\end{array}$ & 974 & 0,2 \\
\hline Symptoms and signs involving the circulatory and respiratory systems (R00-R09) & 849 & 0,1 \\
\hline Arthropathies (M00-M25) & 820 & 0,1 \\
\hline Malignant neoplasm of urinary tract (C64-C68) & 819 & 0,1 \\
\hline Other obstetric conditions, not elsewhere classified (O95-O99) & 811 & 0,1 \\
\hline Other degenerative diseases of the nervous system (G30-G32) & 800 & 0,1 \\
\hline Other disorders of the skin and subcutaneous tissue (L80-L99) & 756 & 0,1 \\
\hline Cerebral palsy and other paralytic syndromes (G80-G83) & 751 & 0,1 \\
\hline Other diseases of pleura (J90-J94) & 662 & 0,1 \\
\hline Diseases of veins, lymphatic vessels and lymph nodes, not elsewhere classified (180-189) & 657 & 0,1 \\
\hline Soft tissue disorders (M60-M79) & 628 & 0,1 \\
\hline Sequelae of infectious and parasitic diseases (B90-B94) & 570 & 0,1 \\
\hline Congenital malformations of the circulatory system (Q20-Q28) & 550 & 0,1 \\
\hline Digestive system disorders of fetus and newborn (P75-P78) & 545 & 0,1 \\
\hline Malignant neoplasm of eye, brain and other parts of central nervous system (C69-C72) & 516 & 0,1 \\
\hline Malignant neoplasm of skin (C43-C44) & 509 & 0,1 \\
\hline Infections of the skin and subcutaneous tissue (L00-L08) & 449 & 0,1 \\
\hline Coagulation defects, purpura and other haemorrhagic conditions (D65-D69) & 441 & 0,1 \\
\hline Complications of medical and surgical care (Y40-Y84) & 438 & 0,1 \\
\hline Chronic rheumatic heart diseases (I05-109) & 390 & 0,1 \\
\hline Viral infections characterized by skin and mucous membrane lesions (B00-B09) & 387 & 0,1 \\
\hline Malignant neoplasms of independent multiple sites (C97) & 385 & 0,1 \\
\hline Systemic connective tissue disorders (M30-M36) & 379 & 0,1 \\
\hline Symptoms and signs involving the digestive system and abdomen (R10-R19) & 373 & 0,1 \\
\hline Intentional self-harm (X60-X84) & 373 & 0,1 \\
\hline Suppurative and necrotic conditions of lower respiratory tract (J85-J86) & 370 & 0,1 \\
\hline Other congenital malformations (Q80-Q89) & 367 & 0,1 \\
\hline Haemorrhagic and haematological disorders of fetus and newborn (P50-P61) & 362 & 0,1 \\
\hline Mental and behavioural disorders due to psychoactive substance use (F10-F19) & 340 & 0,1 \\
\hline Renal tubulo-interstitial diseases (N10-N16) & 339 & 0,1 \\
\hline Viral hepatitis (B15-B19) & 323 & 0,1 \\
\hline Diseases of peritoneum (K65-K67) & 315 & 0,1 \\
\hline Oedema, proteinuria and hypertensive disorders in pregnancy, childbirth and the puerperium (O10-O16) & 305 & 0,1 \\
\hline Extrapyramidal and movement disorders (G20-G26) & 298 & 0,1 \\
\hline Other diseases of urinary system (N30-N39) & 282 & 0,0 \\
\hline Diseases of male genital organs (N40-N51) & 267 & 0,0 \\
\hline Obesity and other hyperalimentation (E65-E68) & 263 & 0,0 \\
\hline Glomerular diseases (N00-N08) & 248 & 0,0 \\
\hline Congenital malformations of the nervous system (Q00-Q07) & 248 & 0,0 \\
\hline Other disorders of kidney and ureter (N25-N29) & 244 & 0,0 \\
\hline Viral infections of the central nervous system (A80-A89) & 241 & 0,0 \\
\hline Disorders of thyroid gland (E00-E07) & 240 & 0,0 \\
\hline Schizophrenia, schizotypal and delusional disorders (F20-F29) & 236 & 0,0 \\
\hline Chromosomal abnormalities, not elsewhere classified (Q90-Q99) & 232 & 0,0 \\
\hline
\end{tabular}


Appendix J: All underlying causes of death, 2009 (continued)

\begin{tabular}{|c|c|c|}
\hline Causes of death (based on the 10th revision, International Classification of Diseases, 1992) & Number & Percent \\
\hline All causes & 572673 & 100,0 \\
\hline Complications predominantly related to the puerperium (O85-O92) & 223 & 0,0 \\
\hline Hernia (K40-K46) & 217 & 0,0 \\
\hline Benign neoplasms (D10-D36) & 214 & 0,0 \\
\hline Polyneuropathies and other disorders of the peripheral nervous system (G60-G64) & 212 & 0,0 \\
\hline Complications of labour and delivery (O60-O75) & 207 & 0,0 \\
\hline Acute upper respiratory infections (J00-J06) & 192 & 0,0 \\
\hline Pregnancy with abortive outcome (O00-O08) & 192 & 0,0 \\
\hline Systemic atrophies primarily affecting the central nervous system (G10-G13) & 187 & 0,0 \\
\hline Inflammatory diseases of female pelvic organs (N70-N77) & 168 & 0,0 \\
\hline Malignant neoplasm of thyroid and other endocrine glands (C73-C75) & 166 & 0,0 \\
\hline Osteopathies and chondropathies (M80-M94) & 157 & 0,0 \\
\hline Malignant neoplasm of bone and articular cartilage (C40-C41) & 147 & 0,0 \\
\hline Dorsopathies (M40-M54) & 147 & 0,0 \\
\hline Other and unspecified disorders of the circulatory system (195-199) & 146 & 0,0 \\
\hline Diseases of appendix (K35-K38) & 142 & 0,0 \\
\hline Urticaria and erythema (L50-L54) & 140 & 0,0 \\
\hline Other congenital malformations of the digestive system (Q38-Q45) & 130 & 0,0 \\
\hline Noninflammatory disorders of female genital tract (N80-N98) & 118 & 0,0 \\
\hline Conditions involving the integument and temperature regulation of fetus and newborn (P80-P83) & 111 & 0,0 \\
\hline Other infectious diseases (B99) & 109 & 0,0 \\
\hline Other diseases of upper respiratory tract (J30-J39) & 108 & 0,0 \\
\hline Infections with a predominantly sexual mode of transmission (A50-A64) & 99 & 0,0 \\
\hline Transitory endocrine and metabolic disorders specific to fetus and newborn (P70-P74) & 93 & 0,0 \\
\hline Demyelinating diseases of the central nervous system (G35-G37) & 91 & 0,0 \\
\hline Diseases of myoneural junction and muscle (G70-G73) & 89 & 0,0 \\
\hline Diseases of middle ear and mastoid $(\mathrm{H} 65-\mathrm{H} 75)$ & 82 & 0,0 \\
\hline Disorders of other endocrine glands (E20-E35) & 76 & 0,0 \\
\hline Other maternal disorders predominantly related to pregnancy (O20-O29) & 76 & 0,0 \\
\hline Congenital malformations and deformations of the musculoskeletal system (Q65-Q79) & 74 & 0,0 \\
\hline Helminthiases (B65-B83) & 69 & 0,0 \\
\hline Diseases of oral cavity, salivary glands and jaws (K00-K14) & 69 & 0,0 \\
\hline Other nutritional deficiencies (E50-E64) & 67 & 0,0 \\
\hline Maternal care related to the fetus and amniotic cavity and possible delivery problems (O30-O48) & 66 & 0,0 \\
\hline Other diseases of blood and blood-forming organs (D70-D77) & 62 & 0,0 \\
\hline Congenital malformations of the respiratory system (Q30-Q34) & 62 & 0,0 \\
\hline Nutritional anaemias (D50-D53) & 59 & 0,0 \\
\hline Congenital malformations of the urinary system (Q60-Q64) & 53 & 0,0 \\
\hline Dermatitis and eczema (L20-L30) & 47 & 0,0 \\
\hline Haemolytic anaemias (D55-D59) & 46 & 0,0 \\
\hline Mood [affective] disorders (F30-F39) & 43 & 0,0 \\
\hline Unspecified mental disorder (F99) & 37 & 0,0 \\
\hline Sequelae of external causes of morbidity and mortality (Y85-Y89) & 33 & 0,0 \\
\hline Disorders of breast (N60-N64) & 28 & 0,0 \\
\hline Bullous disorders (L10-L14) & 25 & 0,0 \\
\hline Abnormal findings on examination of blood, without diagnosis (R70-R79) & 23 & 0,0 \\
\hline Birth trauma (P10-P15) & 22 & 0,0 \\
\hline Urolithiasis (N20-N23) & 21 & 0,0 \\
\hline Symptoms and signs involving cognition, perception, emotional state and behaviour (R40-R46) & 16 & 0,0 \\
\hline Visual disturbances and blindness (H53-H54) & 15 & 0,0 \\
\hline Acute rheumatic fever (I00-102) & 14 & 0,0 \\
\hline
\end{tabular}


Appendix J: All underlying causes of death, 2009 (concluded)

\begin{tabular}{|c|c|c|}
\hline Causes of death (based on the 10th revision, International Classification of Diseases, 1992) & Number & Percent \\
\hline All causes & 572673 & 100,0 \\
\hline Symptoms and signs involving the urinary system (R30-R39) & 14 & 0,0 \\
\hline Abnormal findings on diagnostic imaging and in function studies, without diagnosis (R90-R94) & 14 & 0,0 \\
\hline Neurotic, stress-related and somatoform disorders (F40-F48) & 13 & 0,0 \\
\hline Cleft lip and cleft palate (Q35-Q37) & 13 & 0,0 \\
\hline Certain zoonotic bacterial diseases (A20-A28) & 9 & 0,0 \\
\hline In situ neoplasms (D00-D09) & 9 & 0,0 \\
\hline Nerve, nerve root and plexus disorders (G50-G59) & 8 & 0,0 \\
\hline Congenital malformations of eye, ear, face and neck (Q10-Q18) & 8 & 0,0 \\
\hline Symptoms and signs involving the nervous and musculoskeletal systems (R25-R29) & 8 & 0,0 \\
\hline Arthropod-borne viral fevers and viral haemorrhagic fevers (A90-A99) & 7 & 0,0 \\
\hline Disorders of eyelid, lacrimal system and orbit ( $\mathrm{H} 00-\mathrm{H} 06)$ & 6 & 0,0 \\
\hline Abnormal findings on examination of other body fluids, substances and tissues, without diagnosis (R83-R89) & 6 & 0,0 \\
\hline Glaucoma (H40-H42) & 5 & 0,0 \\
\hline Disorders of skin appendages (L60-L75) & 5 & 0,0 \\
\hline Behavioural syndromes associated with physiological disturbances and physical factors (F50-F59) & 4 & 0,0 \\
\hline Symptoms and signs involving the skin and subcutaneous tissue (R20-R23) & 4 & 0,0 \\
\hline Disorders of choroid and retina $(\mathrm{H} 30-\mathrm{H} 36)$ & 3 & 0,0 \\
\hline Other disorders of eye and adnexa (H55-H59) & 3 & 0,0 \\
\hline Papulosquamous disorders (L40-L45) & 3 & 0,0 \\
\hline Radiation-related disorders of the skin and subcutaneous tissue (L55-L59) & 3 & 0,0 \\
\hline Congenital malformations of genital organs (Q50-Q56) & 3 & 0,0 \\
\hline Symptoms and signs involving speech and voice (R47-R49) & 3 & 0,0 \\
\hline Abnormal findings on examination of urine, without diagnosis (R80-R82) & 3 & 0,0 \\
\hline Other spirochaetal diseases (A65-A69) & 2 & 0,0 \\
\hline Rickettsioses (A75-A79) & 2 & 0,0 \\
\hline Pediculosis, acariasis and other infestations (B85-B89) & 2 & 0,0 \\
\hline Disorders of adult personality and behaviour (F60-F69) & 2 & 0,0 \\
\hline Disorders of conjunctiva $(\mathrm{H} 10-\mathrm{H} 13)$ & 2 & 0,0 \\
\hline Disorders of vitreous body and globe $(\mathrm{H} 43-\mathrm{H} 45)$ & 2 & 0,0 \\
\hline Disorders of ocular muscles, binocular movement, accommodation and refraction (H49-H52) & 2 & 0,0 \\
\hline Other disorders of ear (H90-H95) & 2 & 0,0 \\
\hline Other disorders of the musculoskeletal system (M95-M99) & 2 & 0,0 \\
\hline Disorders of psychological development (F80-F89) & 1 & 0,0 \\
\hline Behavioural and emotional disorders with onset usually occurring in childhood and adolescence (F90-F98) & 1 & 0,0 \\
\hline Disorders of sclera, cornea, iris and ciliary body $(\mathrm{H} 15-\mathrm{H} 22)$ & 1 & 0,0 \\
\hline Disorders of optic nerve and visual pathways ( $\mathrm{H} 46-\mathrm{H} 48)$ & 1 & 0,0 \\
\hline Diseases of inner ear $(\mathrm{H} 80-\mathrm{H} 83)$ & 1 & 0,0 \\
\hline
\end{tabular}


Appendix K: Detailed description of the broad groups of natural causes of death which were among the ten leading causes in 2009

\begin{tabular}{|c|c|c|c|}
\hline \multicolumn{2}{|r|}{ Causes of death (based on the $10^{\text {th }}$ Revision, International Classification of Disease, 1992) } & \multirow[t]{2}{*}{ Number } & \multirow[t]{2}{*}{$\%$} \\
\hline & Intestinal infectious diseases (A00-A09) & & \\
\hline A00 & Cholera (A00) & 47 & 0,2 \\
\hline A01 & Typhoid and paratyphoid fevers (A01) & 12 & 0,0 \\
\hline A02 & Other salmonella infections(A02) & 22 & 0,1 \\
\hline A03 & Shigellosis (A03) & 12 & 0,0 \\
\hline A04 & Other bacterial intestinal infections (A04) & 0 & 0,0 \\
\hline A05 & Other bacterial food-borne intoxications (A05) & 0 & 0,0 \\
\hline A06 & Amoebiasis (A06) & 19 & 0,1 \\
\hline A07 & Other protozoal intestinal diseases (A07) & 14 & 0,0 \\
\hline A08 & Viral and other specified intestinal infections (A08) & 60 & 0,2 \\
\hline \multirow[t]{3}{*}{ A09 } & Diarrhoea and gastroenteritis of presumed infectious origin (A09) & 30489 & 99,4 \\
\hline & Total & 30675 & 100,0 \\
\hline & Tuberculosis (A15-A19) & & \\
\hline A16 & Respiratory tuberculosis, not confirmed bacteriologically or histologically (A16) & 56125 & 81,3 \\
\hline A17 & Tuberculosis of nervous system (A17) & 3671 & 5,3 \\
\hline A18 & Tuberculosis of other organs (A18) & 1930 & 2,8 \\
\hline \multirow[t]{2}{*}{ A19 } & Miliary tuberculosis (A19) & 5942 & 8,6 \\
\hline & Drug-resistant tuberculosis (U51-U52) & & \\
\hline U51 & Multidrug-resistant tuberculosis (U51) & 1184 & 1,7 \\
\hline \multirow[t]{3}{*}{ U52 } & Extensively drug-resistant tuberculosis (U52) & 151 & 0,2 \\
\hline & Total & 69003 & 100,0 \\
\hline & Human immunodeficiency virus [HIV] disease (B20-B24) & & \\
\hline B20 & Human immunodeficiency virus (HIV) disease resulting in infectious and parasitic diseases (B20) & 8834 & 50,3 \\
\hline B21 & Human immunodeficiency virus (HIV) disease resulting in malignant neoplasms (B21) & 286 & 1,6 \\
\hline B22 & Human immunodeficiency virus (HIV) disease resulting in other specified diseases (B22) & 5327 & 30,3 \\
\hline B23 & Human immunodeficiency virus (HIV) disease resulting in other conditions (B23) & 1147 & 6,5 \\
\hline \multirow[t]{3}{*}{ B24 } & Unspecified human immunodeficiency virus (HIV) disease (B24) & 1976 & 11,2 \\
\hline & Total & 17570 & 100,0 \\
\hline & Certain disorders involving the immune mechanism (D80-D89) & & \\
\hline D80 & Immunodeficiency with predominantly antibody defects (D80) & 3 & 0,0 \\
\hline D81 & Combined immunodeficiencies (D81) & 2 & 0,0 \\
\hline D82 & Immunodeficiency associated with other major defects (D82) & 6 & 0,0 \\
\hline D83 & Common variable immunodeficiency (D83) & 21 & 0,2 \\
\hline D84 & Other immunodeficiencies (D84) & 13015 & 99,4 \\
\hline D86 & Sarcoidosis (D86) & 40 & 0,3 \\
\hline \multirow[t]{3}{*}{ D89 } & Other disorders involving the immune mechanism, not elsewhere classified (D89) & 9 & 0,1 \\
\hline & Total & 13096 & 100,0 \\
\hline & Diabetes mellitus (E10-E14) & & \\
\hline E10 & Insulin-dependent diabetes mellitus (E10) & 237 & 1,2 \\
\hline E11 & Non-insulin-dependent diabetes mellitus (E11) & 1135 & 5,5 \\
\hline E12 & Malnutrition-related diabetes mellitus (E12) & 2 & 0,0 \\
\hline E13 & Other specified diabetes mellitus (E13) & 0 & 0,0 \\
\hline \multirow[t]{2}{*}{ E14 } & Unspecified diabetes mellitus (E14) & 19149 & 93,3 \\
\hline & Total & 20523 & 100,0 \\
\hline
\end{tabular}




\section{Appendix K: Detailed description of the broad groups of natural causes of death which were among the ten leading causes in 2009 (continued)}

\begin{tabular}{|c|c|c|c|}
\hline \multicolumn{2}{|r|}{ Causes of death (based on the $10^{\text {th }}$ Revision, International Classification of Disease, 1992) } & \multirow[t]{2}{*}{ Number } & \multirow[t]{2}{*}{$\%$} \\
\hline & Hypertensive diseases (I10-I15) & & \\
\hline 110 & Essential (primary) hypertension (I10) & 7467 & 48,5 \\
\hline 111 & Hypertensive heart disease (I11) & 6627 & 43,1 \\
\hline 112 & Hypertensive renal disease (I12) & 1045 & 6,8 \\
\hline \multirow[t]{3}{*}{113} & Hypertensive heart and renal disease (I13) & 247 & 1,6 \\
\hline & Total & 15386 & 100,0 \\
\hline & Other forms of heart disease (130-152) & & \\
\hline 130 & Acute pericarditis (I30) & 10 & 0,0 \\
\hline 131 & Other diseases of pericardium (I31) & 238 & 0,9 \\
\hline 133 & Acute and subacute endocarditis (I33) & 71 & 0,3 \\
\hline 134 & Nonrheumatic mitral valve disorders (I34) & 88 & 0,3 \\
\hline 135 & Nonrheumatic aortic valve disorders (I35) & 201 & 0,8 \\
\hline 136 & Nonrheumatic tricuspid valve disorders (I36) & 0 & 0,0 \\
\hline 137 & Pulmonary valve disorders (I37) & 4 & 0,0 \\
\hline 138 & Endocarditis, valve unspecified (I38) & 196 & 0,7 \\
\hline 140 & Acute myocarditis (140) & 36 & 0,1 \\
\hline 142 & Cardiomyopathy (142) & 3485 & 13,2 \\
\hline 144 & Atrioventricular and left bundle-branch block (144) & 29 & 0,1 \\
\hline 145 & Other conduction disorders (145) & 56 & 0,2 \\
\hline 146 & Cardiac arrest (146) & 4106 & 15,5 \\
\hline 147 & Paroxysmal tachycardia (147) & 25 & 0,1 \\
\hline 148 & Atrial fibrillation and flutter (148) & 402 & 1,5 \\
\hline 149 & Other cardiac arrhythmias (149) & 274 & 1,0 \\
\hline 150 & Heart failure (I50) & 16405 & 62,0 \\
\hline \multirow[t]{3}{*}{151} & Complications and ill-defined descriptions of heart disease (I51) & 836 & 3,2 \\
\hline & Total & 26462 & 100,0 \\
\hline & Cerebrovascular diseases (160-169) & & \\
\hline 160 & Subarachnoid haemorrhage (I60) & 342 & 1,4 \\
\hline 161 & Intracerebral haemorrhage (I61) & 951 & 3,8 \\
\hline 162 & Other nontraumatic intracranial haemorrhage (I62) & 481 & 1,9 \\
\hline 163 & Cerebral infarction (I63) & 521 & 2,1 \\
\hline 164 & Stroke, not specified as haemorrhage or infarction (164) & 21583 & 86,9 \\
\hline 165 & Occlusion and stenosis of precerebral arteries, not resulting in cerebral infarction (I65) & 0 & 0,0 \\
\hline 166 & Occlusion and stenosis of cerebral arteries, not resulting in cerebral infarction (I66) & 0 & 0,0 \\
\hline 167 & Other cerebrovascular diseases (I67) & 650 & 2,6 \\
\hline \multirow[t]{3}{*}{169} & Sequelae of cerebrovascular disease (169) & 307 & 1,2 \\
\hline & Total & 24835 & 100,0 \\
\hline & Influenza and pneumonia (J09-J18) & & \\
\hline J09 & Influenza due to identified avian influenza virus (J09) & 14 & 0,0 \\
\hline J10 & Influenza due to identified influenza virus (J10) & 33 & 0,1 \\
\hline J11 & Influenza, virus not identified (J11) & 743 & 1,7 \\
\hline J12 & Viral pneumonia, not elsewhere classified (J12) & 41 & 0,1 \\
\hline J13 & Pneumonia due to Streptococcus pneumoniae (J13) & 16 & 0,0 \\
\hline J14 & Pneumonia due to Haemophilus influenzae (J14) & 7 & 0,0 \\
\hline J15 & Bacterial pneumonia, not elsewhere classified (J15) & 245 & 0,6 \\
\hline J16 & Pneumonia due to other infectious organisms, not elsewhere classified (J16) & 6 & 0,0 \\
\hline \multirow[t]{2}{*}{ J18 } & Pneumonia, organism unspecified (J18) & 41859 & 97,4 \\
\hline & Total & 42964 & 100,0 \\
\hline
\end{tabular}




\section{Appendix K: Detailed description of the broad groups of natural causes of death which were among the ten leading causes in 2009 (concluded)}

\begin{tabular}{|c|c|c|c|}
\hline \multicolumn{2}{|c|}{ Causes of death (based on the $10^{\text {th }}$ Revision, International Classification of Disease, 1992) } & \multirow[t]{2}{*}{ Number } & \multirow[t]{2}{*}{$\%$} \\
\hline & Chronic lower respiratory diseases $(\mathrm{J} 40-\mathrm{J} 47)$ & & \\
\hline J40 & Bronchitis, not specified as acute or chronic (J40) & 822 & 5,8 \\
\hline J41 & Simple and mucopurulent chronic bronchitis (J41) & 3 & 0,0 \\
\hline J42 & Unspecified chronic bronchitis (J42) & 623 & 4,4 \\
\hline J43 & Emphysema (J43) & 867 & 6,1 \\
\hline J44 & Other chronic obstructive pulmonary disease (J44) & 6123 & 43,2 \\
\hline J45 & Asthma (J45) & 4552 & 32,1 \\
\hline J46 & Status asthmaticus (J46) & 1009 & 7,1 \\
\hline \multirow[t]{2}{*}{ J47 } & Bronchiectasis (J47) & 185 & 1,3 \\
\hline & Total & 14184 & 100,0 \\
\hline
\end{tabular}




\section{Appendix L: The ten leading underlying natural causes of death by age and sex: South Africa, 2009}

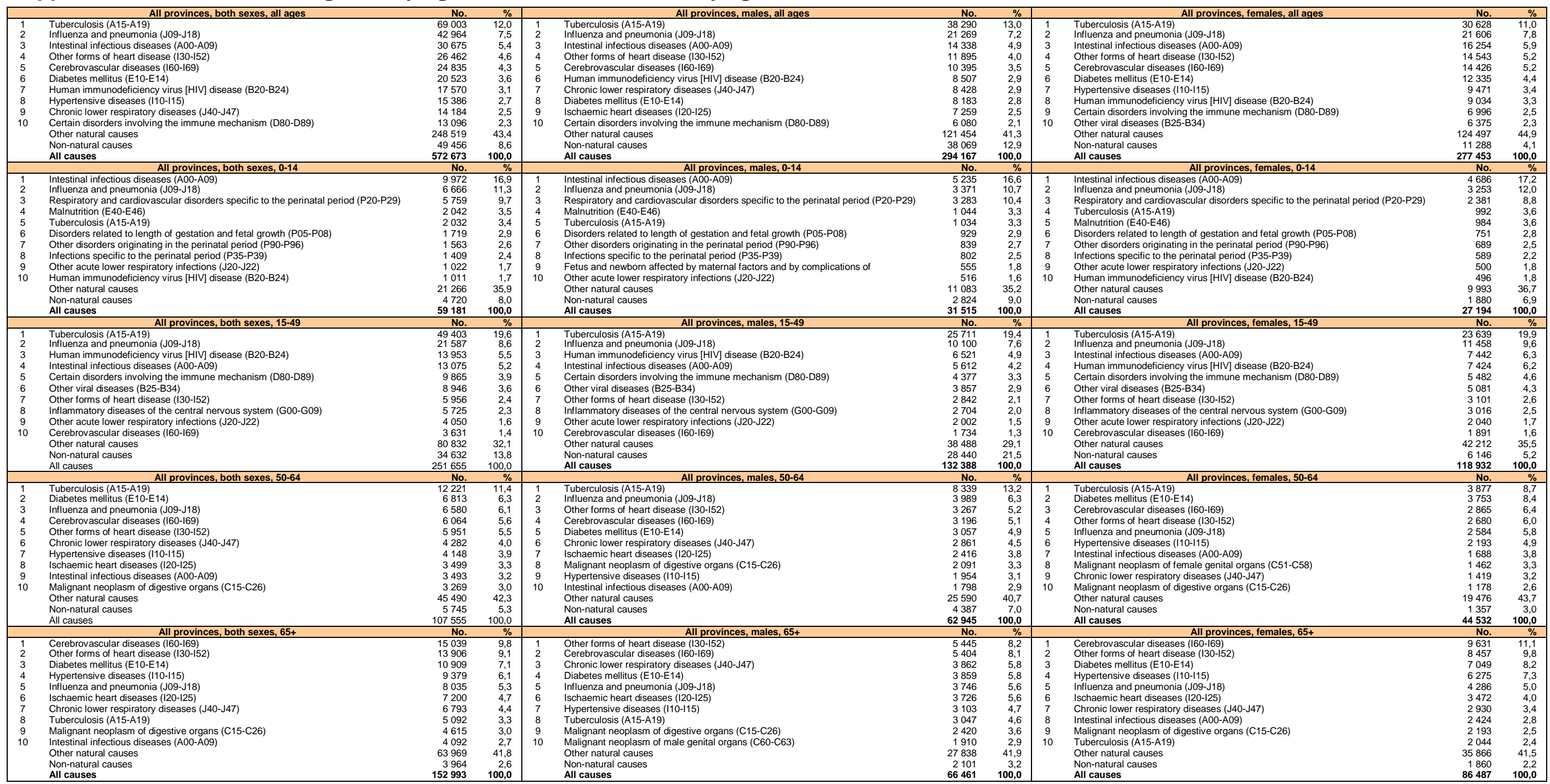

* Including deaths due to MDR-TB and XDR-TB 
Appendix L.1: The ten leading underlying natural causes of death by age and sex: Western Cape, 2009

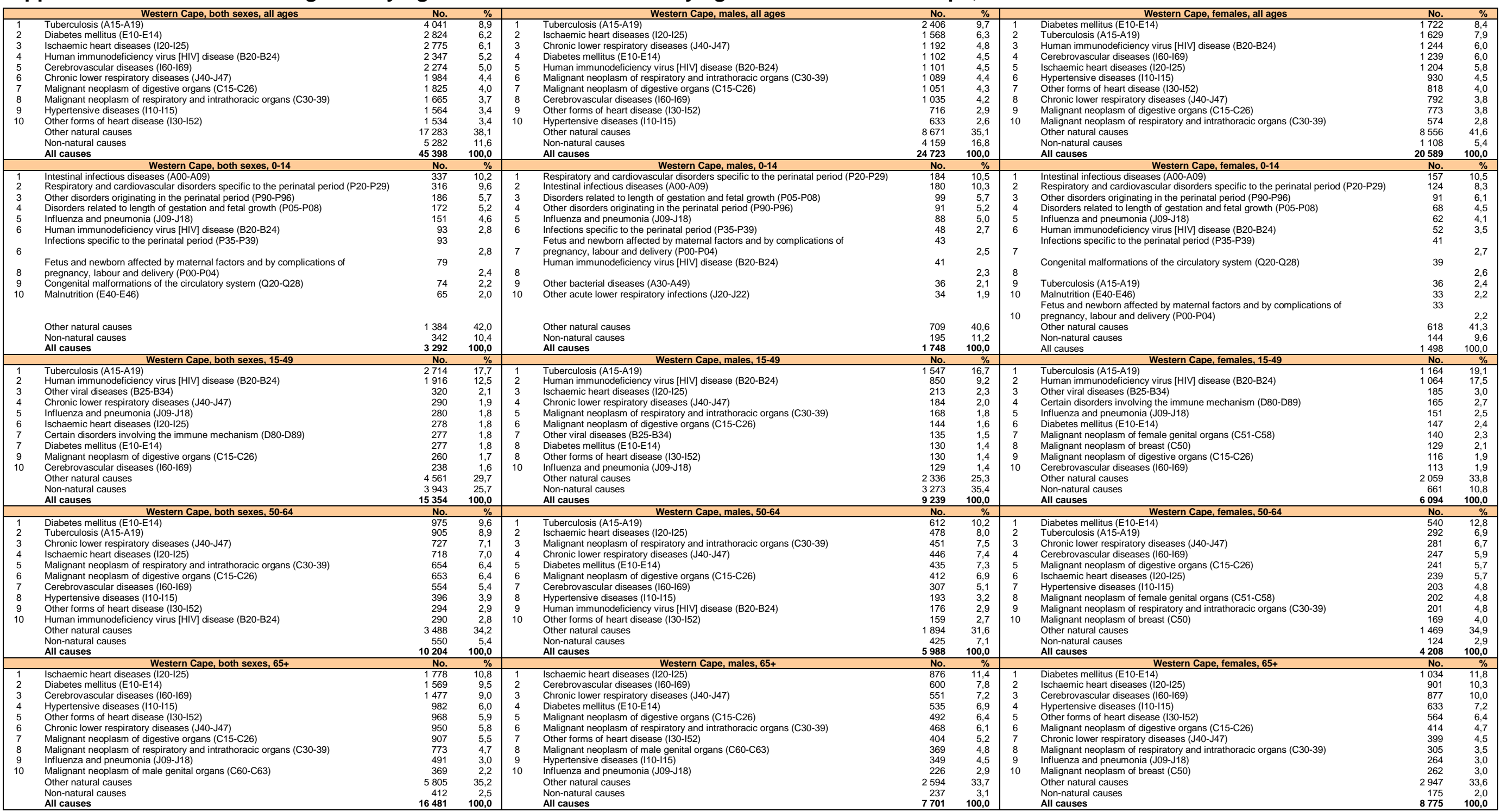

*Including deaths due to MDR-TB and XDR-TB 


\section{Appendix L.2: The ten leading underlying natural causes of death by age and sex: Eastern Cape, 2009}

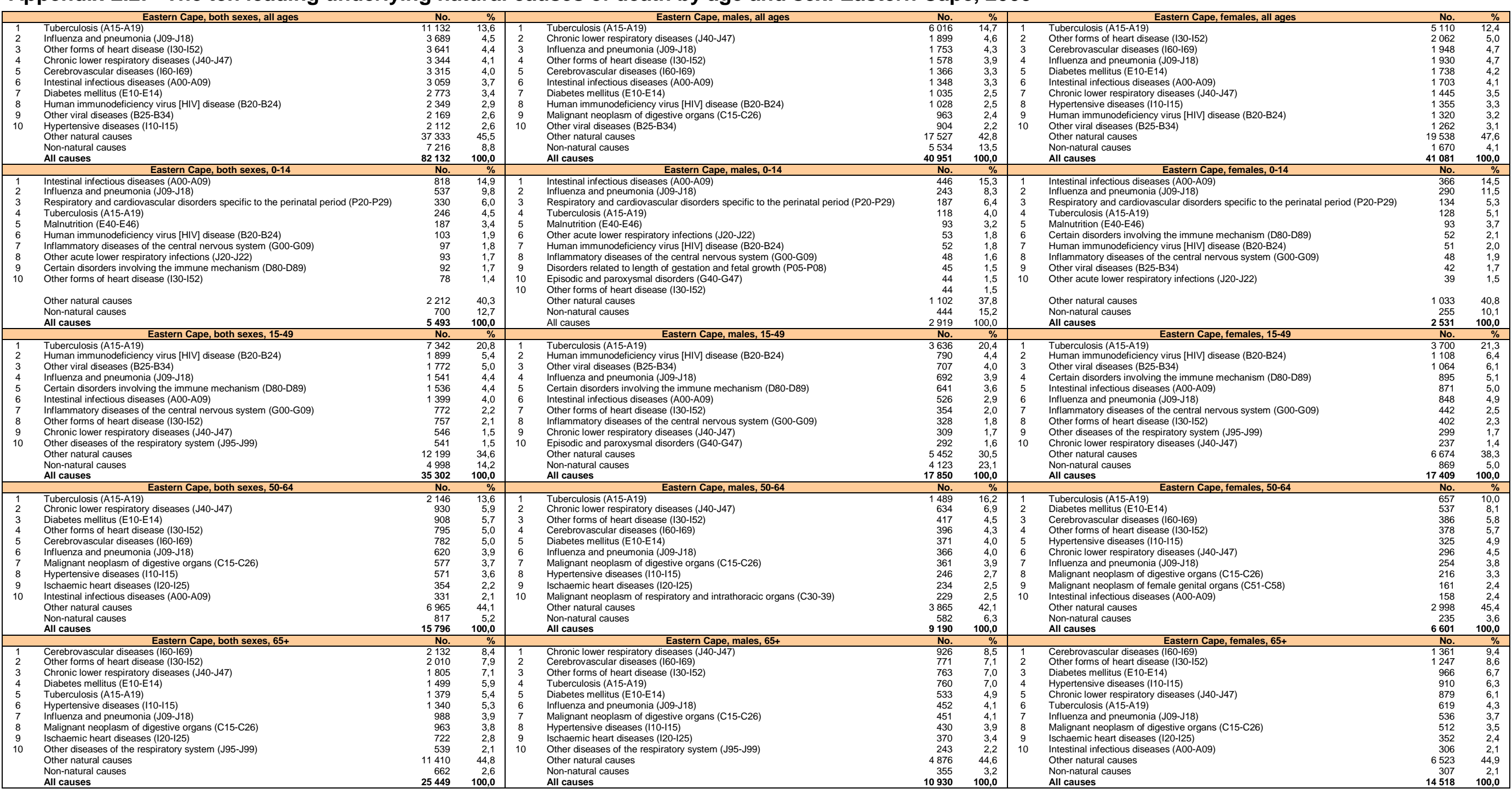

* Including deaths due to MDR-TB and XDR-TB 


\section{Appendix L.3: The ten leading underlying natural causes of death by age and sex: Northern Cape, 2009}

\begin{tabular}{|c|c|c|c|c|c|c|c|c|c|c|}
\hline $\begin{array}{c}1 \\
2 \\
3 \\
4 \\
5 \\
6 \\
7 \\
8 \\
9 \\
10\end{array}$ & 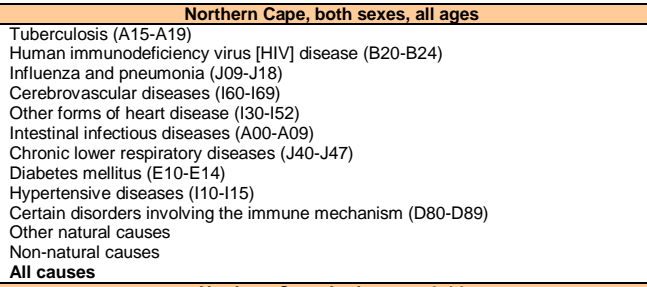 & $\begin{array}{r}\text { No. } \\
1465 \\
883 \\
844 \\
632 \\
582 \\
577 \\
575 \\
449 \\
447 \\
383 \\
6970 \\
1275 \\
15082\end{array}$ & $\begin{array}{r}\%, \\
9,7 \\
5,9 \\
5,6 \\
4,2 \\
3,9 \\
3,8 \\
3,8 \\
3,0 \\
3,0 \\
2,5 \\
46,2 \\
8,5 \\
100,0 \\
\end{array}$ & 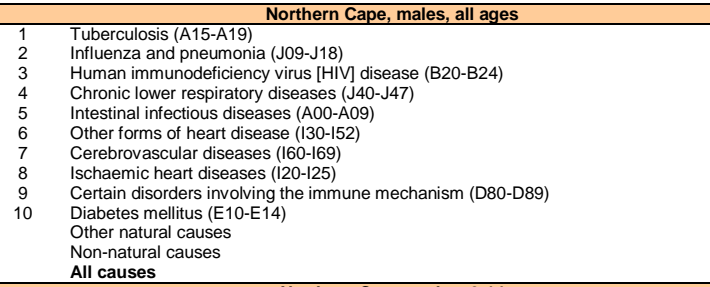 & $\begin{array}{l}\text { No. } \\
864 \\
430 \\
419 \\
382 \\
281 \\
272 \\
257 \\
206 \\
188 \\
178 \\
3464 \\
918 \\
7859 \\
\end{array}$ & $\begin{array}{r}\% \\
11,0 \\
5,5 \\
5,3 \\
4,9 \\
3,6 \\
3,5 \\
3,3 \\
2,6 \\
2,4 \\
2,3 \\
44,1 \\
11,7 \\
100,0\end{array}$ & $\begin{array}{c}1 \\
2 \\
3 \\
4 \\
5 \\
6 \\
7 \\
7 \\
9 \\
10\end{array}$ & 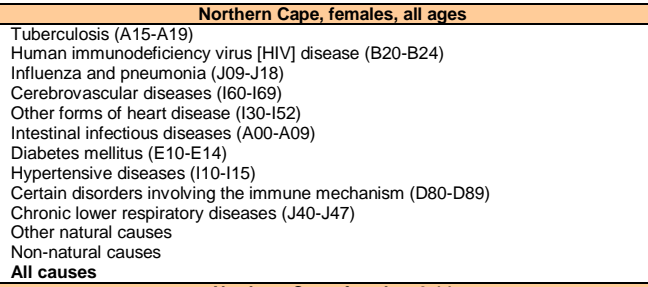 & $\begin{aligned} & \text { No. } \\
& 601 \\
& 646 \\
& 414 \\
& 375 \\
& 310 \\
& 296 \\
& 271 \\
& 271 \\
& 194 \\
& 193 \\
& 3460 \\
& 355 \\
& 7204 \\
&\end{aligned}$ & $\begin{array}{r}\% \\
8,3 \\
6,4 \\
5,7 \\
5,2 \\
4,3 \\
4,1 \\
3,8 \\
3,8 \\
2,7 \\
2,7 \\
48,0 \\
4,9 \\
100,0 \\
\end{array}$ \\
\hline & Northern Cape, both sexes, 0.14 & $\frac{15082}{\text { No. }}$ & & All causes $\quad$ Northern Cape, males, $0-14$ & $\begin{array}{ll}859 \\
\text { No. }\end{array}$ & & & All causes $\quad$ Northern Cape, females, $0-14$ & Nou & \\
\hline & & & & & & & & & & \\
\hline & 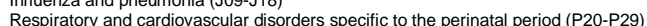 & & & seviratorr and cardiovascular disorders speciific to & & & 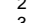 & oneumonia (Jo & 63 & 31 \\
\hline 4 & Disorders related to length of gestation and fetal growth (P05-P08) & 102 & 6,4 & 4 Disorders related to length of gestation and fetal growth (PO5- & 55 & 6,6 & & $\begin{array}{l}\text { Malnutrition (E40-E46) } \\
\text { (Eccular }\end{array}$ & 53 & 7,1 \\
\hline 5 & 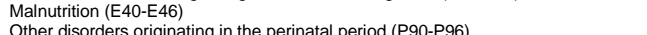 & 85 & 5,3 & Other disorders originating in the perinatal period ( $\mathrm{P} 90-\mathrm{PS}$ & 33 & 4,0 & 5 & Disorders related to length of gestation and fetal growth (P05-P08) & 44 & 5,9 \\
\hline $\begin{array}{l}0 \\
7\end{array}$ & 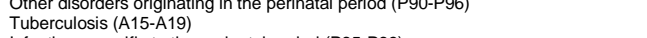 & & & $\begin{array}{l}\text { Malnutrntion (E44-4-46) } \\
\text { Infections specific to the perinatal period (P35-P39) }\end{array}$ & $\begin{array}{l}31 \\
24\end{array}$ & $\begin{array}{l}3,1 \\
2,9\end{array}$ & & $\begin{array}{l}\text { Other disorders orignataing in the perrinatal } \\
\text { Tuberculosis }(\mathrm{A} 15-\mathrm{A} 19)\end{array}$ & 20 & $\begin{array}{l}3,6 \\
2,7\end{array}$ \\
\hline$\stackrel{8}{9}$ & $\begin{array}{l}\text { Infections speciitic to the perinatal period (P35-P39) } \\
\text { Other bacterial liseases ( } 30 \text { - } A 499 \text { ) }\end{array}$ & ${ }_{31}^{36}$ & $\begin{array}{l}2,3 \\
1,9\end{array}$ & $\begin{array}{l}\text { Tuberculosis (A15-A19) } \\
\text { Human immunodeficiency virus } \mathrm{HHIV} \text { disease (B20-B22 }\end{array}$ & 19 & 2,3 & $\begin{array}{l}8 \\
9\end{array}$ & $\begin{array}{l}\text { Other bacterial diseases (A30-A49) } \\
\text { Certain disorders involving the eimmu }\end{array}$ & 17 & $\begin{array}{l}2,3 \\
2,3\end{array}$ \\
\hline & 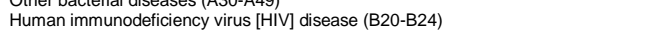 & 31 & 1,9 & Other acute lower respiratory infections ( $(220-\mathrm{J} 222)$ & 14 & $\begin{array}{l}2,3 \\
1,7\end{array}$ & $\begin{array}{l}10 \\
10\end{array}$ & $\begin{array}{l}\text { Human immunuodeficiency virus }(\text { HIIVI disease (B22-B24) } \\
\text { Other acute lower respiratory infections (J20-J22) }\end{array}$ & $\begin{array}{l}10 \\
12 \\
12\end{array}$ & $\begin{array}{l}2,2 \\
1,6 \\
1,6\end{array}$ \\
\hline & Other natural causes & 531 & 33,3 & Other natural causes & 262 & 31,4 & & $\begin{array}{l}\text { Other riseases of the respiratory } \\
\text { Other natural causes }\end{array}$ & $\begin{array}{r}12 \\
235\end{array}$ & 1,6 \\
\hline & $\begin{array}{l}\text { Non-natural } \\
\text { AAl causes }\end{array}$ & $\begin{array}{r}144 \\
1595\end{array}$ & $\begin{array}{r}9,0 \\
100,0\end{array}$ & $\begin{array}{l}\text { Non-natural } \\
\text { All causes }\end{array}$ & $\begin{array}{r}87 \\
835\end{array}$ & $\begin{array}{r}10,4 \\
1000\end{array}$ & & $\begin{array}{l}\text { Non-natural causes } \\
\text { All causes }\end{array}$ & $\begin{array}{r}55 \\
743\end{array}$ & $\begin{array}{r}7,4 \\
1000\end{array}$ \\
\hline \multirow{11}{*}{$\begin{array}{r}1 \\
2 \\
3 \\
4 \\
5 \\
6 \\
7 \\
8 \\
9 \\
10\end{array}$} & Northern Cape, both sexes, $15-49$ & No. & & Northern Cape, males, 15-49 & 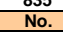 & & & Northern Cape, females, $15-49$ & No. & \\
\hline & Tuberculosis (A15-A19) & 1024 & 16,5 & Tuberculosis (A15-A19) & 570 & 17,3 & 1 & Tuberculosis (A15-A19) & 454 & 15,5 \\
\hline & iency virus (HIV] disease (B20-B24) & 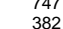 & 6.1 & 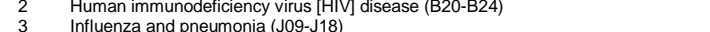 & $\begin{array}{l}347 \\
169\end{array}$ & & & 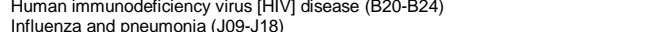 & &, 7 \\
\hline & $\begin{array}{l}\text { Intuenze } \\
\text { Certain }\end{array}$ & 281 & 4.5 & g the immune mechanism & ${ }_{138}$ & 42 & 4 & the inmune mecha & 1143 & 7,3 \\
\hline & (A00-A09) & 185 & 3,0 & us diseases (A00-A09) & & $\begin{array}{l}2, \mathrm{c} \\
2,4\end{array}$ & & $\begin{array}{l}\text { Intestinal infectious diseases (AOO-AO9) } \\
\text { (n) }\end{array}$ & 107 & $\begin{array}{l}4,9 \\
3,7\end{array}$ \\
\hline & $\begin{array}{l}\text { Other acute lower respiratory infections (J20-J22) } \\
\text { Other viral diseases (225-B34) }\end{array}$ & $\begin{array}{l}126 \\
120\end{array}$ & $\begin{array}{l}2,0 \\
1,9\end{array}$ & $\begin{array}{l}\text { Chronic lower respiratory diseases ( J40-J } \\
\text { Other forms of heart disease (130-152) }\end{array}$ & $\begin{array}{l}65 \\
60\end{array}$ & $\begin{array}{l}2,0 \\
1,8\end{array}$ & $\begin{array}{l}6 \\
7\end{array}$ & $\begin{array}{l}\text { Other viral diseases (B25-B34) } \\
\text { Other acute lower ressiratory infections (J20-J22) }\end{array}$ & 69 & $\frac{2,4}{23}$ \\
\hline & Other forms of heart disease (130-152) & 117 & 1,9 & 8 Other acute lower respiratory ynfections (J20-J22) & 59 & 1,8 & 8 & Other forms of heart disease (130-152) & 57 & 1,9 \\
\hline & $\begin{array}{l}\text { Chronic lower respiratory diseases (J40-J47) } \\
\text { Other diseases of the respiratory system (J95--99) }\end{array}$ & ${ }_{104}^{110}$ & 1,8 & $\begin{array}{l}\text { Other viral diseases (B25-B34) } \\
\text { Otherd diseases }\end{array}$ & $\begin{array}{r}51 \\
51\end{array}$ & 1,5 & 9 & $\begin{array}{l}\text { Cerebrov } \\
\text { Otherdis }\end{array}$ & 53 & 1,8 \\
\hline & $\begin{array}{l}\text { Other natural causes } \\
\text { Othpiratory } \mathrm{s} \text {, }\end{array}$ & 2132 & 34,3 & $\begin{array}{l}\text { Other dileseases of the respiratory } \\
\text { Other natural causes }\end{array}$ & $\begin{array}{r}51 \\
1018\end{array}$ & $\begin{array}{l}3,5,9 \\
30\end{array}$ & & $\begin{array}{l}\text { Other diseases of the respiratory sys } \\
\text { Other natural causes }\end{array}$ & $\begin{array}{r}53 \\
1105\end{array}$ & 37,7 \\
\hline & $\begin{array}{l}\text { Non-natural causes } \\
\text { All causes }\end{array}$ & $\begin{array}{r}894 \\
6222\end{array}$ & $\begin{array}{r}14,4 \\
100,0\end{array}$ & $\begin{array}{l}\text { Non-natural causes } \\
\text { All causes }\end{array}$ & $\begin{array}{r}685 \\
3291\end{array}$ & $\begin{array}{r}20,8 \\
100,0\end{array}$ & & $\begin{array}{l}\text { Non-natural causes } \\
\text { All causes }\end{array}$ & $\begin{array}{r}209 \\
2930\end{array}$ & 7,1 \\
\hline & & No. & $\%$ & Northern Cape, males, $50-64$ & No. & $\%$ & & Northern Cape, females, 50-64 & No. & $\%$ \\
\hline \multirow{9}{*}{$\begin{array}{r}2 \\
3 \\
4 \\
5 \\
6 \\
7 \\
8 \\
9 \\
10\end{array}$} & $\begin{array}{l}\text { Tuberculosis (A15-A19) } \\
\text { Chronic }\end{array}$ & 210 & & $\begin{array}{l}\text { Tuberculosis (A1 } \\
\text { Chronic lower res }\end{array}$ & 151 & $\begin{array}{ll}11,5 \\
8,5\end{array}$ & & 9) & 92 & 86 \\
\hline & Cerebrov & 157 & $\begin{array}{l}0,6 \\
5,0\end{array}$ & 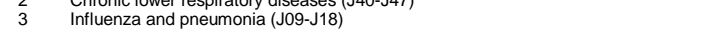 & 86 & $\begin{array}{l}8,8 \\
4,8\end{array}$ & 3 & 152) & 78 & 5,6 \\
\hline & Influ & 149 & & Celevorascu & 70 & 3,9 & & Diabetes mellitus $(E)$ & 73 & 5,2 \\
\hline & $\begin{array}{l}\text { Otther forms of heart disease (130 } \\
\text { Diabetes mellitus (E10-E14) }\end{array}$ & ${ }_{136}^{138}$ & $\begin{array}{l}4,4 \\
4,3\end{array}$ & $\begin{array}{ll}5 & \text { Maliginant neoplasm of digestive organs ( (15-C26) } \\
5 & \text { Malignant neoplasm of respiratory and intrathoracic organs (C30-39) }\end{array}$ & $\begin{array}{l}68 \\
68\end{array}$ & $\begin{array}{l}3,8 \\
3,8\end{array}$ & $\begin{array}{l}5 \\
6\end{array}$ & $\begin{array}{l}\text { Hypertensive diseases (I10-115) } \\
\text { Influenza a and pneumonia (J09-J18) }\end{array}$ & $\begin{array}{l}72 \\
63 \\
\end{array}$ & $\begin{array}{l}5,2 \\
4,5\end{array}$ \\
\hline & 115) & 122 & 3,8 & $(120-125)$ & 68 & 3,8 & 7 & Chro & 59 & 4,2 \\
\hline & igestive organs (C15-C26) & 120 & 3,8 & ${ }_{9}^{8}$ & 63 & 3,5 & 8 & Maligr & $\begin{array}{r}52 \\
49\end{array}$ & 3,7 \\
\hline & 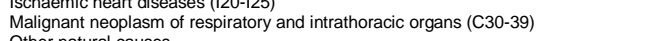 & 101 & $\begin{aligned} 3,4 \\
3,2\end{aligned}$ & 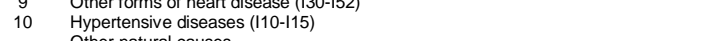 & $\begin{array}{r}60 \\
50\end{array}$ & $\begin{array}{l}3,4 \\
2,8\end{array}$ & ${ }_{10}^{9}$ & $\begin{array}{l}\text { Malignant neoplasm or emaie gential organs } \\
\text { Human immunodeficiency virus (HIV) disease (B20-B24) }\end{array}$ & ${ }_{42}^{49}$ & $\begin{array}{l}3,0,0 \\
3,0\end{array}$ \\
\hline & Oth & $\begin{array}{r}1500 \\
131\end{array}$ & $\begin{array}{r}47,3 \\
4,1\end{array}$ & ises & 799 & $\begin{array}{r}44,9 \\
5,1\end{array}$ & & es & & ,.19 \\
\hline & $\begin{array}{l}\text { All causes } \\
\text { canting }\end{array}$ & 3170 & $\begin{array}{r}4,1,0 \\
100,0\end{array}$ & $\begin{array}{l}\text { All causes } \\
\text { Allation }\end{array}$ & 1778 & $\begin{array}{r}5,1,0 \\
100,0\end{array}$ & & $\begin{array}{l}\text { Non-natural } \\
\text { All causes }\end{array}$ & $\begin{array}{r}431 \\
391\end{array}$ & $\begin{array}{r}2,9 \\
100,0\end{array}$ \\
\hline \multirow{9}{*}{$\begin{array}{r}1 \\
2 \\
3 \\
4 \\
5 \\
6 \\
7 \\
8 \\
9 \\
10\end{array}$} & ape, & No. & & Northern Cape, $m_{2}$ & No. & & & Northern $\mathrm{C}$ & No. & \\
\hline & $\mathrm{Ce}$ & 315 & 9,5 & $(\mathrm{J40}-\mathrm{-J47})$ & 161 & 8,3 & 1 & ases $(160-169)$ & 5 & 11,0 \\
\hline & Hypertensive diseas & 270 & 6,6 & $\begin{array}{l}\text { Cererorovascularar icseaseses (160-169) } \\
\text { Other forms of heart disease (130-152) }\end{array}$ & 145 & 7,8 & 3 & 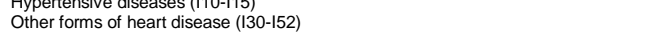 & 70 & 8,0 \\
\hline & $\begin{array}{l}\text { tory diseases (J40-J47) } \\
\text { t-F14) }\end{array}$ & 249 & $\begin{array}{l}6,1 \\
58\end{array}$ & ${ }_{5}^{4}$ & 102 & 5,2 & & -E14) & 155 & 7,2 \\
\hline & & 179 & $\begin{array}{l}4,8 \\
4,4\end{array}$ & $\begin{array}{l}0.15)(18) \\
(J 09-J 18)\end{array}$ & 98 & $\begin{array}{l}\begin{array}{l}5,0 \\
5,0\end{array}\end{array}$ & $\begin{array}{l}5 \\
6\end{array}$ & iratory disea & 77 & $\begin{array}{l}4,1 \\
3,6\end{array}$ \\
\hline & Influenza and pneumonia (J09-J18) & 172 & 4,2 & 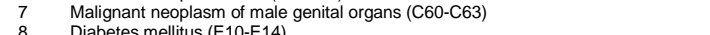 & 82 & 4,2 & 7 & $-\mathrm{J18}$ & 75 & 3,5 \\
\hline & $\begin{array}{l}\text { Malilinant neoplasm of digestive organs ( } \\
\text { Malignant neoplasm of respiratory and int }\end{array}$ & 113 & $\begin{array}{l}3,3 \\
2,8\end{array}$ & $\begin{array}{l}\text { Diabeetes melitulus (E10-E14) } \\
\text { Malignant neoplasm of respiratory and intrathoracic orga }\end{array}$ & 76 & $\begin{array}{l}4,1 \\
3,9\end{array}$ & $\begin{array}{l}8 \\
9\end{array}$ & $\begin{array}{l}\text { Malingant neoplasm of digestive orgal } \\
\text { Malignant neoplasm of female genital }\end{array}$ & $\begin{array}{l}73 \\
64\end{array}$ & $\begin{array}{l}3,4 \\
3,0\end{array}$ \\
\hline & $\begin{array}{l}\text { Tuberculosis (A15-A19) } \\
\text { Other natural causes }\end{array}$ & $\begin{array}{r}102 \\
1825\end{array}$ & $\begin{array}{r}2,5 \\
44,7\end{array}$ & $\begin{array}{l}\text { Tuberculosis (A15-A19) } \\
\text { Other natural causes }\end{array}$ & $\begin{array}{r}68 \\
832\end{array}$ & $\begin{array}{r}3,5 \\
42,7\end{array}$ & & $\begin{array}{l}\text { Intestinal infectious diseases (A00-A09) } \\
\text { Other natural causes }\end{array}$ & $\begin{array}{r}41 \\
938\end{array}$ & $\begin{array}{r}1,9 \\
43,9\end{array}$ \\
\hline & & 4085 & 0,0 & 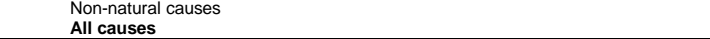 & 947 & 00,0 & & All caus & $\begin{array}{r}50 \\
2138\end{array}$ & \\
\hline
\end{tabular}

* Including deaths due to MDR-TB and XDR-TB 


\section{Appendix L.4: The ten leading underlying natural causes of death by age and sex: Free State, 2009}

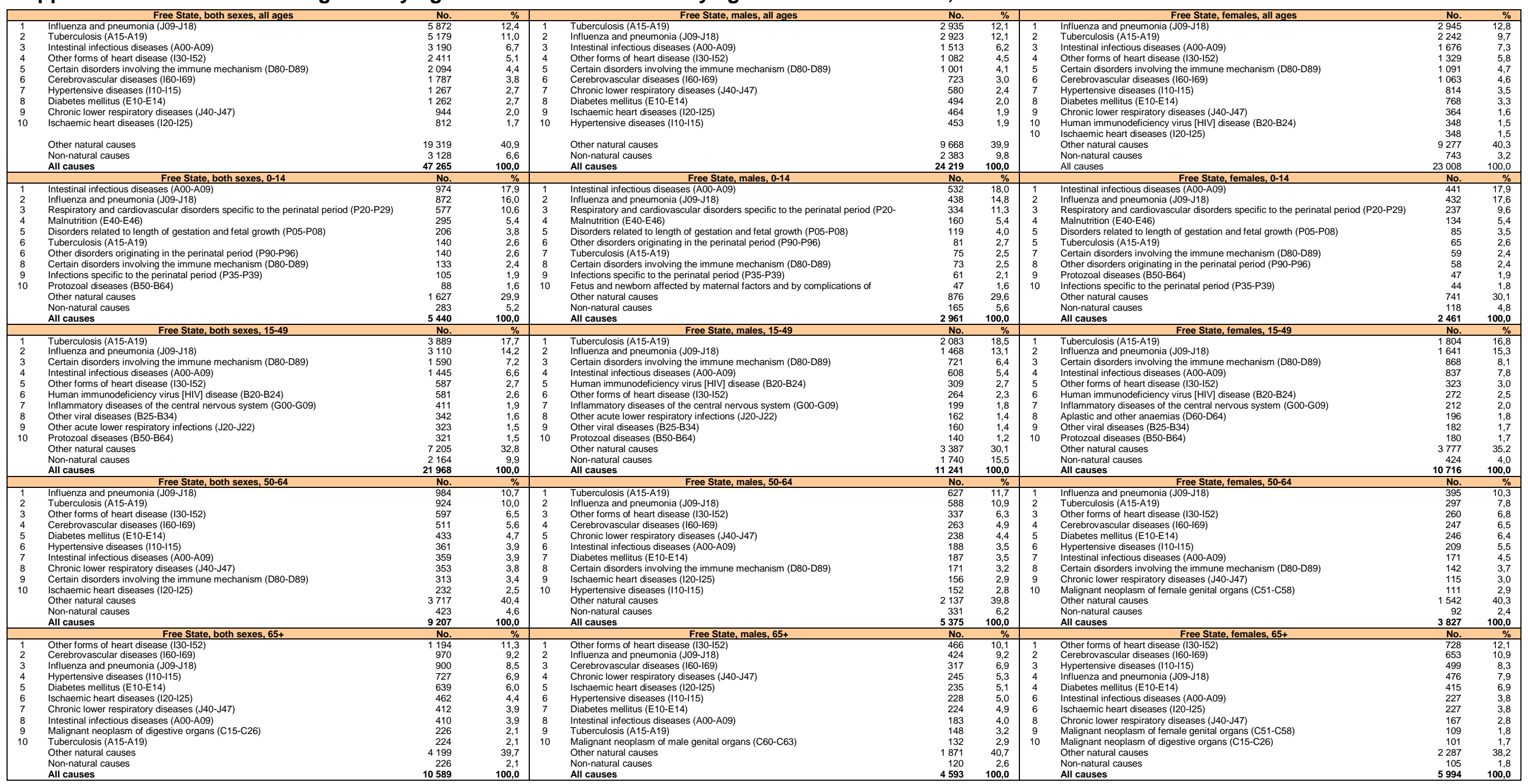

*Including deaths due to MDR-TB and XDR-TB 


\section{Appendix L.5: The ten leading underlying natural causes of death by age and sex: KwaZulu-Natal, 2009}

\begin{tabular}{|c|c|c|c|c|c|c|c|c|c|c|c|}
\hline & $\begin{array}{l}\text { KwaZulu-Natal, both sexes, all ages } \\
\text { Tuberculosis (A15-A19) }\end{array}$ & $\frac{\text { No. }}{20618}$ & $\frac{\%}{16,2}$ & 1 & \begin{tabular}{|l} 
KwaZulu-Natal, males, all ages \\
Tuberculosis (A15-A19)
\end{tabular} & $\frac{\text { No. }}{11190}$ & $\frac{\%}{17,4}$ & 1 & $\begin{array}{l}\text { KwaZulu-Natal, females, all ages } \\
\text {-A19) }\end{array}$ & $\frac{\text { No. }}{9404}$ & $\frac{\%}{14,9}$ \\
\hline 2 & $\begin{array}{l}\text { Intertinal infectious diseases (A00-A09) } \\
\text { Intestis }\end{array}$ & 7907 & 6,2 & 2 & Intestinal infectious diseases (A00-A09) & 3727 & 5,8 & & Intestinal infectious diseases (A00-A09) & 4156 & 过 \\
\hline 3 & Influenza and pneumonia (J09-J18) & 7197 & 5,7 & & Influenza and pneumonia (J09-J18) & 3616 & 5,6 & 3 & Cerebrovascular diseases (160-169) & 3863 & 6,1 \\
\hline 4 & $\begin{array}{l}\text { Cerebrovascular diseasese (160-169) } \\
\text { Other forms of heart disease } 1(10-152)\end{array}$ & 6257. & 4,9 & & $\begin{array}{l}\text { Cerebrovascular diseases (160-169) } \\
\text { Other }\end{array}$ & 2390 & 3,7 & & Influenza and pneumonia (J09- & 3570 & 5,7 \\
\hline $\begin{array}{l}5 \\
6 \\
6\end{array}$ & $\begin{array}{l}\text { Other forms of heart disisease (130-152) } \\
\text { Diabetes mellitus (E10-E14) }\end{array}$ & $\begin{array}{l}5351 \\
4901\end{array}$ & 4, & & $\begin{array}{l}\text { Other forms of heart disease (130-152) } \\
\text { Human immunodeficiency virus [HIV] disease (B20-B24) }\end{array}$ & 2276 & 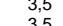 & 5 & 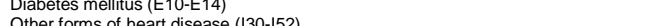 & 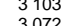 & 4,9 \\
\hline & Human immunodeficiency virus [HIV] disease (B20-B24) & 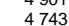 & 帛, & & 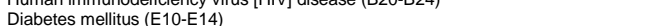 & 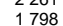 & 2.8 & 7 & 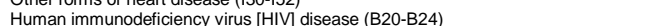 & 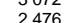 & $\begin{array}{l}4,9 \\
3,9\end{array}$ \\
\hline 8 & Other viral diseases (B25-B34) & 3798 & 3,0 & 8 & Other viral diseases (B25-B34) & 1735 & $\begin{array}{l}2,7 \\
2,7\end{array}$ & 8 & Other viral diseases (B25-B34) & 2059 & $\begin{array}{l}3,9 \\
3,3\end{array}$ \\
\hline Y & Other acute lower respiratory infections (J20-J22) & 2669 & 2,1 & 9 & Ischaemic heart disseases (120-125) & 1485 & 2,3 & 9 & Hypertensive diseases (110-115) & 1655 & 2,6 \\
\hline & $\begin{array}{l}\text { Hypertensive diseases (110-115) } \\
\text { Other natural causes }\end{array}$ & $\begin{array}{r}2631 \\
50498\end{array}$ & $\begin{array}{r}2,1 \\
39,6\end{array}$ & & $\begin{array}{l}\text { ther acute lower respiratory infections (J20-J22) } \\
\text { Other natural causes }\end{array}$ & $\begin{array}{r}1381 \\
23988\end{array}-100$ & $\begin{array}{r}2,2 \\
37,4\end{array}$ & & $\begin{array}{l}\text { Other acute lower respiratory infections (J20-J22) } \\
\text { Other natural causses }\end{array}$ & $\begin{array}{r}1282 \\
25913\end{array}$ & $\begin{array}{r}2,0 \\
41,1\end{array}$ \\
\hline & Non-natural causes & & & & $\begin{array}{l}\text { Non-natural causes } \\
\text { Nats }\end{array}$ & & & & $\begin{array}{l}\text { OOner natural causes } \\
\text { Non-natural causes }\end{array}$ & $\begin{array}{r}25913 \\
2462\end{array}$ & \\
\hline & All causes & 127369 & 100,0 & & All causes & 64174 & 100,0 & & All causes & 63015 & $\begin{array}{r}3,9 \\
100,0\end{array}$ \\
\hline & KwaZulu-Natal, both sexes, 0-14 & No. & $\%$ & & KwaZulu-Natal, males, 0-14 & No. & $\%$ & & KwaZulu-Natal, females, 0-14 & No. & $\%$ \\
\hline $\begin{array}{l}1 \\
2 \\
2\end{array}$ & 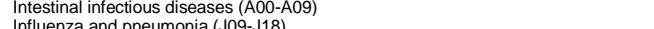 & 2284 & 17,6 & 1 & 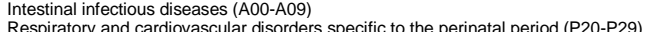 & 1168 & 17,0 & 1 & 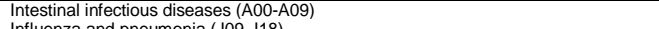 & 104 & 18,4 \\
\hline & Respiratory and cardiovascular disorders specific to the perinatal period (P20-P29) & 1151 & 89 & & 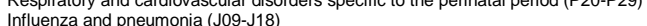 & 的 & & & Respiratory and cardiovascular disorders speciific to the perinatal pe & & 9,2 \\
\hline & Tuberculosis (A15-A19) & 689 & 5,3 & & 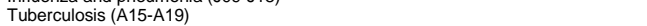 & 348 & 5,1 & & & 337 & $\begin{array}{l}7,8 \\
5,6\end{array}$ \\
\hline 5 & Disorders related to length of gestation and fetal growth (P05-P08) & 437 & 3,4 & & Disorders related to length of gestation and fetal growth ( $\mathrm{P05}-\mathrm{P} 08$ ) & 233 & 3,4 & 5 & Disorders related to length of gestation and fetal growth (P05-P08) & 194 & 3,2 \\
\hline 6 & $\begin{array}{l}\text { Malnutrition (E40-E46) } \\
\text { lntections sencifictothe perinatal period (P35-P39) }\end{array}$ & 398 & 3,1 & 6 & Infections specific to the perinatal period (P35-P39) & 207 & 3,0 & 6 & Malnutrition (E40-E46) & 188 & 3,1 \\
\hline & $\begin{array}{l}\text { Infections speceific to the perinatal period ( } \mathrm{P3} 3 \text {-P39) } \\
\text { Human immunodeficiency virus (HIV) disease (B20-B24) }\end{array}$ & $\begin{array}{l}361 \\
327\end{array}$ & 2,8 & & $\begin{array}{l}\text { Mallanurtition (E40--E46) } \\
\text { Human immunodeficiency virus [HIV] disease (B20-B24 }\end{array}$ & 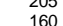 & 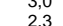 & 8 & $\begin{array}{l}\text { Human immunuodediciency virus (HII) disisease (B20--B24) } \\
\text { Infections specific to the perinatal period (P35-P39) }\end{array}$ & 153 & 2,7 \\
\hline & $\begin{array}{l}\text { Other disorders originating in the perinatal period (P90-P96) } \\
\text { Ond }\end{array}$ & 278 & & & Fetus and newborn affected by maternal factors and by complications of & 158 & & & $\begin{array}{l}\text { Other disorders originating in the perinatal period (P90-Pg } \\
\text { Oto }\end{array}$ & 119 & 2,0 \\
\hline 10 & Fetus and newborn affected by maternal factors and by complications of & 276 & 2,1 & 10 & Other disorders originating in the perinatal period (P90-P96) & 152 & 2,2 & 10 & Fetus and newborn affected by maternal factors and by complications of & 115 & 1,9 \\
\hline & $\begin{array}{l}\text { Other natural causes } \\
\text { Non-natural }\end{array}$ & $\begin{array}{r}4445 \\
1150\end{array}$ & 34,3 & & $\begin{array}{l}\text { Other natural causes } \\
\text { Non }\end{array}$ & 2286 & 33,3 & & Other natural causes & 2140 & 35,6 \\
\hline & $\begin{array}{l}\text { Non-natural causes } \\
\text { All causes }\end{array}$ & $\begin{array}{r}150 \\
12960\end{array}$ & $\begin{array}{r}80,9 \\
10,0\end{array}$ & & $\begin{array}{l}\text { Nonn-natural causes } \\
\text { All causes }\end{array}$ & $\begin{array}{r}669 \\
6863\end{array}$ & $\begin{array}{r}9,7 \\
100,0\end{array}$ & & $\begin{array}{l}\text { Nonn-natural causes } \\
\text { All causes }\end{array}$ & $\begin{array}{r}480 \\
6013\end{array}$ & $\begin{array}{r}8,0 \\
100,0\end{array}$ \\
\hline & $\begin{array}{c}\text { KwaZulu-Natal, both sexes, } 15-49 \\
\end{array}$ & No. & $\%$ & & KwaZulu-Natal, males, 15-49 & No. & $\%$ & & KwaZulu-Natal, females, 15-49 & No. & $\%$ \\
\hline $\begin{array}{l}1 \\
2 \\
\end{array}$ & $\begin{array}{l}\text { Tuberculosisis (A15-A19) } \\
\text { Intestinal infectious diseases (A00-A09) }\end{array}$ & $\begin{array}{c}15390 \\
3804\end{array}$ & $\begin{array}{r}24,8 \\
6,1\end{array}$ & & $\begin{array}{l}\text { Tuberculosis (A15-A19) } \\
\text { Human immunodeficiency virus [HIV] disease (B20-B24) }\end{array}$ & $\begin{array}{l}7911 \\
1778\end{array}$ & $\begin{array}{r}24,3 \\
5,5\end{array}$ & $\begin{array}{l}1 \\
2 \\
2\end{array}$ & $\begin{array}{l}\text { Tuberculuosis (AA5-A19) } \\
\text { Intestinal infectious diseases (A00-A09) }\end{array}$ & $\begin{array}{l}7465 \\
2034\end{array}$ & 65,4 \\
\hline & Human immunodeficiency virus [HIV] disease (B20-B24) & & 6,1 & & Influenza and pneumonia (J09- & 1770 & 5,4 & 3 & Human immunodeficiency virus [HIV] disease (B20-B24) & 201 & 6,9 \\
\hline 4 & Influenza and pneumonia (J09-J18) & 3700 & 6,0 & 4 & Intestinal infectious diseases (AOO-A09) & 1761 & 5,4 & 4 & Influenza and pneumonia (J09-J18) & 1929 & 6,6 \\
\hline $\begin{array}{l}5 \\
6\end{array}$ & $\begin{array}{l}\text { Other viral diseases (B25-BH4) } \\
\text { Inflammatory diseases of the central nerrous system (G00-G09) }\end{array}$ & $\begin{array}{l}2998 \\
1598\end{array}$ & $\begin{array}{l}4,8 \\
26\end{array}$ & & 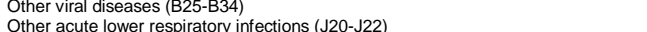 & 1347 & 4,1 & 5 & $\begin{array}{l}\text { Other viral diseaseses (B25-BS4) } \\
\text { Inflammatory diseases of the central } r\end{array}$ & 1648 & 5,6 \\
\hline & 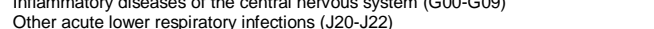 & 15 & 2,6 & & 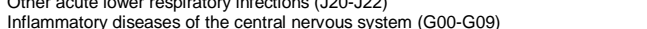 & 740 & 2,3 & & 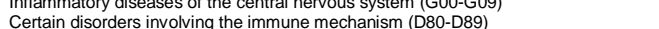 & 820 & 2,9 \\
\hline 8 & Certain disorders involving the immune mechanism (D80-D89) & 1536 & 2,5 & 8 & Certain disorders involving the immune mechanism (D80-D89) & 716 & 2,2 & 8 & 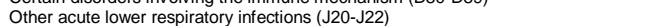 & 795 & 2,7 \\
\hline 9 & Other forms of heart disease (130-152) & 1162 & 1,9 & 9 & Other forms of heart disease (130-152) & 575 & 1,8 & 9 & Other forms of heart disease (130-152) & 586 & 2,0 \\
\hline & $\begin{array}{l}\text { Protozoal diseaseses (B50-B64) } \\
\text { Other natural causes }\end{array}$ & 17850 & $\begin{array}{r}1,5 \\
28\end{array}$ & & $\begin{array}{l}\text { Cerebrovascularar diseases (160-169) } \\
\text { Other natural cuases }\end{array}$ & & $\begin{array}{r}1,4 \\
257\end{array}$ & & $\begin{array}{l}\text { Protozoal diseasese (B50-B64) } \\
\text { Other natural causes }\end{array}$ & 579 & $\begin{array}{r}2,0 \\
319\end{array}$ \\
\hline & $\begin{array}{l}\text { Ontere naturalal causes } \\
\text { Non-natural causes }\end{array}$ & $\begin{array}{l}17841 \\
7614\end{array}$ & $\begin{array}{l}28,8 \\
12,3 \\
2\end{array}$ & & $\begin{array}{l}\text { Irter raturar cacases } \\
\text { Non-natural causes }\end{array}$ & $\begin{array}{l}8361 \\
6361\end{array}$ & $\begin{array}{l}25,1 \\
19,5\end{array}$ & & $\begin{array}{l}\text { Irner naturar cacases } \\
\text { Non-natural causes }\end{array}$ & 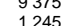 & \\
\hline & All causes & 61948 & 100,0 & & All causes & 32539 & 100,0 & & All causes & 29349 & $\begin{array}{r}4,2 \\
100,0\end{array}$ \\
\hline & KwaZulu-Natal, both sexes, 50-64 & No. & $\%$ & & KwaZulu-Natal, males, 50-64 & No. & $\%$ & & KwaZulu-Natal, females, 50-64 & No. & 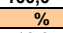 \\
\hline $\begin{array}{l}1 \\
2 \\
2\end{array}$ & $\begin{array}{l}\text { Tuberculosis (A15-A19) } \\
\text { Diabetes mellitus }\end{array}$ & $\begin{array}{l}3111 \\
1704\end{array}$ & $\begin{array}{l}14,1 \\
77\end{array}$ & $\frac{1}{2}$ & $\begin{array}{l}\text { Tuberculosis (A15-A19) } \\
\text { Cererborovascular diseases (160-169) }\end{array}$ & $\begin{array}{l}2108 \\
763\end{array}$ & $\begin{array}{c}16,6 \\
60\end{array}$ & $\frac{1}{2}$ & $\begin{array}{l}\text { Diabetes mellitus (E10-E14) } \\
\text { Tuberculosis A A5 }-A 19)\end{array}$ & 1021 & 10,9 \\
\hline & 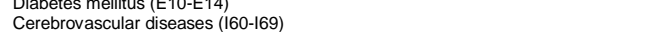 & 15 & 6,9 & & $\begin{array}{l}\text { Cereborovascular diseaseses (160-169) } \\
\text { Diabetes mellitus (E10-E14) }\end{array}$ & 683 & 5,4 & & diseases (160-169) & $\begin{array}{l}100 \\
74\end{array}$ & 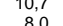 \\
\hline 4 & Other forms of heart disease (130-152) & 1227 & 5,6 & & Other forms of heart disease (130-152) & 661 & 5,2 & 4 & $\begin{array}{l}\text { Other forms of heart disease (130-152) } \\
\text { Ots }\end{array}$ & 566 & $\begin{array}{ll}8,0 \\
6,1 \\
6\end{array}$ \\
\hline 5 & Influenza an & 1043 & 4,7 & & Influenza and pneumonia (J09-J18) & 629 & 5,0 & & Intestinal infectious diseases ( & 431 & 4,6 \\
\hline 6 & (l) & $\begin{array}{l}891 \\
802\end{array}$ & $\begin{array}{l}4,0 \\
4,0\end{array}$ & & 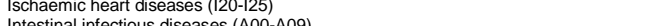 & 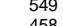 & 4,3 & ${ }_{7}^{6}$ & Influenza and pneumonia (JO) & 413 & 4,4 \\
\hline & $\begin{array}{l}\text { Ischaemic hearar diseaseses (120-12. } \\
\text { Hypertensive diseases (110-115) }\end{array}$ & 702 & $\begin{array}{l}3,6 \\
3,2\end{array}$ & 8 & $\begin{array}{l}\text { Intestunal infectious diseaseses (A00-A09) } \\
\text { Chronic lower respiratory diseases (J40-J }\end{array}$ & 382 & $\begin{array}{l}3,6 \\
3,0\end{array}$ & 8 & 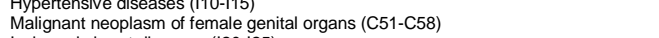 & $\begin{array}{l}366 \\
263\end{array}$ & $\begin{array}{ll}3,9 \\
2,8\end{array}$ \\
\hline 9 & Chronic lower respiriatory diseases ( $(400-\mathrm{J} 47$ ) & 553 & 2,5 & 9 & Hypertensive diseases (110-115) & 336 & 2,6 & 9 & Ischaemic heart diseases (120-125) & 244 & 2,6 \\
\hline & $\begin{array}{l}\text { Human immunuodeficiency virus [HIV] disease (B20-B24) } \\
\text { Other natural causes }\end{array}$ & 8834 & 40,1 & & $\begin{array}{l}\text { Malignantn neopplaum of digestive organs (C15-C26) } \\
\text { Other natural causes }\end{array}$ & 4970 & $\begin{array}{r}2,4 \\
39,2\end{array}$ & & $\begin{array}{l}\text { Other viral diseases (B25-B34) } \\
\text { Other natural causes }\end{array}$ & $\begin{array}{r}243 \\
3728\end{array}$ & $\begin{array}{r}2,6 \\
399\end{array}$ \\
\hline & $\begin{array}{l}\text { Non-natural causes } \\
\text { Allyuses }\end{array}$ & 153 & 5,2 & & $\begin{array}{l}\text { Non-natural causes } \\
\text { Nuses }\end{array}$ & 845 & 6,7 & & $\begin{array}{l}\text { Non-natural causes } \\
\text { Nuns }\end{array}$ & 308 & 3,3 \\
\hline & All causes & 22031 & 100,0 & & KwaZulu-Natal, males, $65+$ & $\frac{12692}{\text { No. }}$ & 100,0 & & KwaZulu-Natal, females, $65+$ & $\frac{9335}{\text { NNo. }}$ & 100,0 \\
\hline & ases $(160-169)$ & 3793 & $\frac{1.0}{12,6}$ & & es (160-169) & 1171 & $\frac{10}{9,9}$ & & ses (160-169) & 2619 & $\frac{10}{14,4}$ \\
\hline 2 & e (130-152) & 2843 & 9,5 & 2 & art disease (130-152) & 976 & 8,3 & 2 & e (130-152) & 1865 & 10,3 \\
\hline 4 & Hyo & 1595 & 5,3 & & 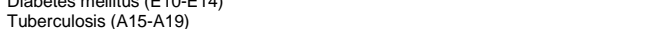 & 740 & 6.3 & 4 & Hyp & $\begin{array}{l}47 \\
15\end{array}$ & 6,6 \\
\hline 5 & Ischaemi & 1425 & 4,8 & & liseases (120-125) & 702 & 5,9 & 5 & nic neart aise & 23 & , \\
\hline 6 & Tuberculosis (A & & 4,3 & & (J09-J18) & 593 & 5,0 & 6 & Influenza and pneumonia (J09- 118$)$ & 671 & 3,7 \\
\hline & $\begin{array}{l}\text { Influenza and pneut } \\
\text { Chronic lower respin }\end{array}$ & $\begin{array}{l}266 \\
968\end{array}$ & 4,2 & $\begin{array}{l}7 \\
8\end{array}$ & $\begin{array}{l}\text { Chronic lower respiratory diseases (J4 } \\
\text { Hypertensiviv diseases (I11-0.115) }\end{array}$ & $\begin{array}{l}548 \\
480\end{array}$ & $\begin{array}{l}4,6 \\
4,4\end{array}$ & $\begin{array}{l}7 \\
8\end{array}$ & $\begin{array}{l}\text { Intestinal infectious diseas } \\
\text { Tuberculosis (A15-A19) }\end{array}$ & 559 & $\begin{array}{l}3,2 \\
3,2\end{array}$ \\
\hline $\begin{array}{l}8 \\
9\end{array}$ & 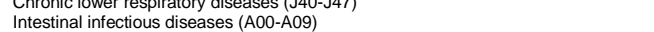 & 908 & $\begin{array}{l}3,2 \\
3,0\end{array}$ & $\begin{array}{l}8 \\
9\end{array}$ & $\begin{array}{l}\text { Hypertensivive diseaseses (110-115) } \\
\text { Malignant neoplasm of digestive organs (C15-C26) }\end{array}$ & 341 & 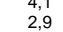 & $\stackrel{\circ}{9}$ & $\begin{array}{l}\text { Tuberulosis } \\
\text { Chronic lower respiration) diseases (J40-J47 }\end{array}$ & 420 & $\begin{array}{l}3,1 \\
2,3\end{array}$ \\
\hline & $\begin{array}{l}\text { Malignann neooplasm of digestive organs (C15-C26) } \\
\text { Other natural causes }\end{array}$ & $\begin{array}{r}675 \\
11815\end{array}$ & $\begin{array}{r}2,3 \\
39,4\end{array}$ & & $\begin{array}{l}\text { Intestinal infectious diseases (A00-A09) } \\
\text { Other natural causes }\end{array}$ & $\begin{array}{r}329 \\
4687\end{array}$ & $\begin{array}{r}2,8 \\
39,7\end{array}$ & & $\begin{array}{l}\text { Malignant neoplasm of digestive organs (C15-C26) } \\
\text { Other natural causes }\end{array}$ & 334 & 1,8 \\
\hline & auses & T10 & 2,7 2,7 & & Non-nati & & & & & 421 & ${ }_{3}^{3}$ \\
\hline & All causes & 29986 & 100,0 & & All causes & 11800 & 100,0 & & All causes & 18176 & 100,0 \\
\hline
\end{tabular}

*Including deaths due to MDR-TB and XDR-TB 
Appendix L.6: The ten leading underlying natural causes of death by age and sex: North West, 2009

\begin{tabular}{|c|c|c|c|c|c|c|c|c|c|c|c|}
\hline $\begin{array}{l}12 \\
3 \\
4 \\
5 \\
6 \\
7 \\
8 \\
9 \\
10\end{array}$ & 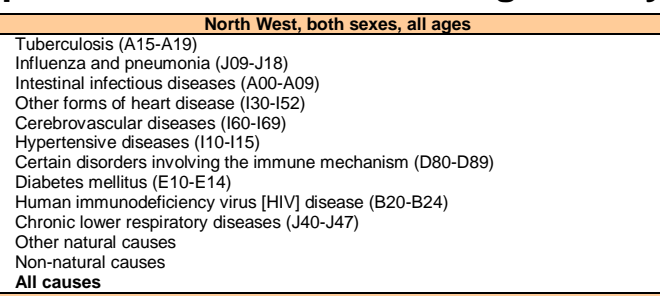 & $\begin{array}{r}\text { No. } \\
4982 \\
3895 \\
2331 \\
2285 \\
1572 \\
1536 \\
1282 \\
1063 \\
980 \\
945 \\
16611 \\
2890 \\
40372\end{array}$ & $\begin{array}{r}12,3 \\
9,6 \\
5,8 \\
5,7 \\
3,9 \\
3,8 \\
3,2 \\
2,6 \\
2,4 \\
2,3 \\
41,1 \\
7,2 \\
100,0 \\
\end{array}$ & $\begin{array}{c}1 \\
2 \\
3 \\
4 \\
5 \\
6 \\
7 \\
8 \\
9 \\
10\end{array}$ & 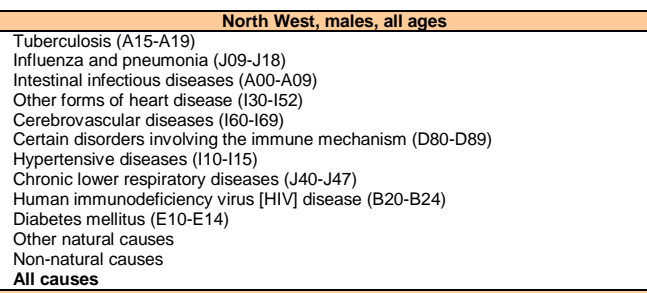 & $\begin{array}{r}\text { No. } \\
2900 \\
1992 \\
1151 \\
1111 \\
761 \\
643 \\
555 \\
554 \\
458 \\
455 \\
8467 \\
2236 \\
21283\end{array}$ & $\begin{array}{r}13,6 \\
9,4 \\
5,4 \\
5,2 \\
3,6 \\
3,0 \\
2,6 \\
2,6 \\
2,2 \\
2,2 \\
39, \\
10,5 \\
100,0 \\
\end{array}$ & $\begin{array}{l}2 \\
3 \\
4 \\
5 \\
6 \\
7 \\
8 \\
9 \\
10\end{array}$ & 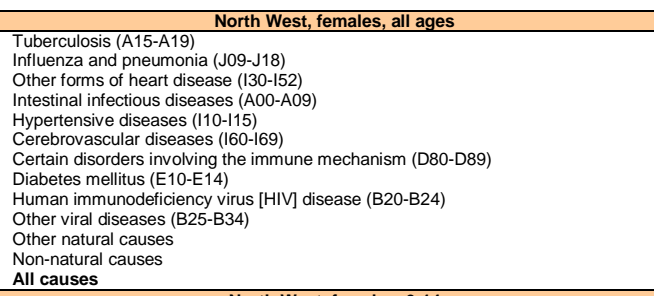 & $\begin{array}{r}\text { No. } \\
2080 \\
1894 \\
1173 \\
1166 \\
981 \\
809 \\
637 \\
607 \\
522 \\
456 \\
8024 \\
650 \\
18999 \\
\end{array}$ & $\begin{array}{r}10,9 \\
10,0 \\
6,2 \\
6,1 \\
5,2 \\
4,3 \\
3,4 \\
3,2 \\
2,7 \\
2,4 \\
42,2 \\
3,4 \\
100,0 \\
\end{array}$ \\
\hline $\begin{array}{l}2 \\
3 \\
4 \\
5 \\
6 \\
7 \\
8 \\
9 \\
9\end{array}$ & 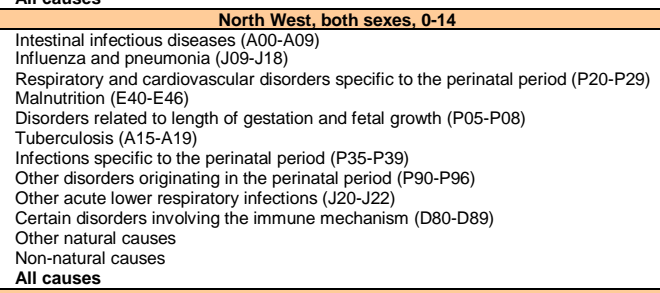 & $\begin{aligned} \text { No. } \\
1070 \\
728 \\
604 \\
266 \\
182 \\
171 \\
156 \\
153 \\
111 \\
104 \\
1636 \\
270 \\
5451\end{aligned}$ & $\begin{array}{r}\%, \% \\
19,6 \\
13,4 \\
11,1 \\
4,9 \\
3,3 \\
3,1 \\
2,9 \\
2,8 \\
2,0 \\
1,9 \\
30,0 \\
5,0 \\
100,0 \\
\end{array}$ & $\begin{array}{l}2 \\
3 \\
4 \\
5 \\
6 \\
7 \\
8 \\
9 \\
10\end{array}$ & 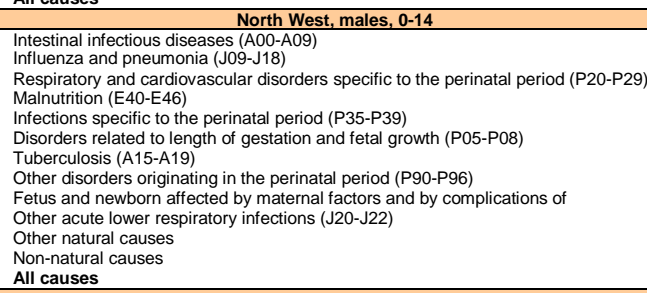 & $\begin{array}{r}\text { No. } \\
573 \\
361 \\
340 \\
147 \\
88 \\
85 \\
84 \\
79 \\
63 \\
57 \\
848 \\
162 \\
2887 \\
2\end{array}$ & $\begin{array}{r}\%, \% \\
19,8 \\
1,5 \\
11,8 \\
5,1 \\
3,0 \\
2,0 \\
2,9 \\
2,7 \\
2,2 \\
2,2 \\
29,4 \\
5,4 \\
100,0 \\
\end{array}$ & $\begin{array}{r}1 \\
2 \\
3 \\
4 \\
5 \\
6 \\
7 \\
8 \\
9 \\
10\end{array}$ & 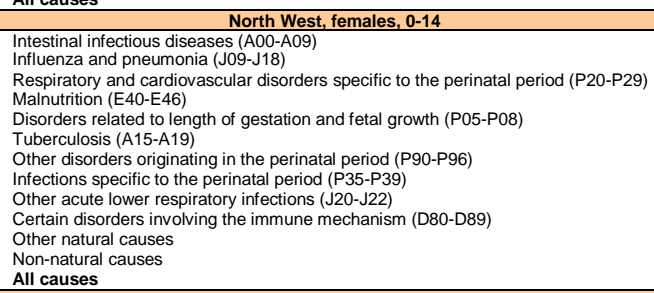 & $\begin{array}{r}\text { No. } \\
485 \\
360 \\
255 \\
118 \\
92 \\
87 \\
68 \\
66 \\
54 \\
48 \\
769 \\
107 \\
2509 \\
\end{array}$ & $\begin{array}{r}2,2 \\
1,9 \\
30,6 \\
4,3 \\
400,0 \\
\end{array}$ \\
\hline $\begin{array}{l}2 \\
3 \\
4 \\
5 \\
6 \\
7 \\
8 \\
9\end{array}$ & 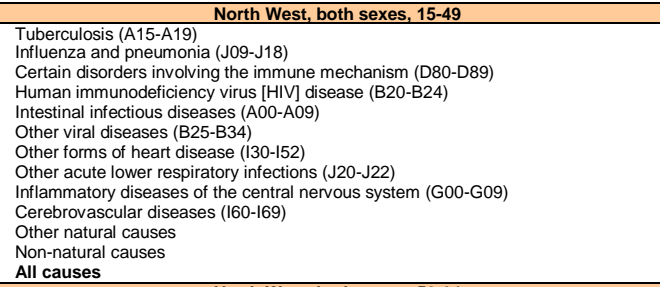 & $\begin{array}{r}\text { No. } \\
3432 \\
2102 \\
950 \\
780 \\
766 \\
640 \\
550 \\
282 \\
280 \\
214 \\
5144 \\
1987 \\
17127\end{array}$ & $\begin{array}{r}\% \\
20,1 \\
10,9 \\
5,5 \\
5,1 \\
3,6 \\
3,4 \\
3,1 \\
1,9 \\
1,7 \\
1,4 \\
30,8 \\
12,5 \\
100,0 \\
\end{array}$ & $\begin{array}{l}2 \\
3 \\
4 \\
5 \\
6 \\
7 \\
8 \\
9 \\
10\end{array}$ & 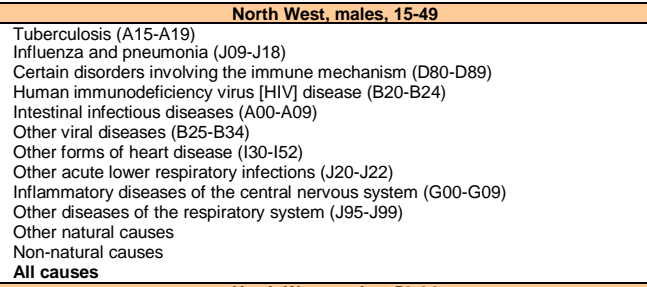 & $\begin{array}{r}\text { No. } \\
1866 \\
1007 \\
457 \\
356 \\
314 \\
289 \\
268 \\
135 \\
133 \\
110 \\
2382 \\
1615 \\
8932 \\
\end{array}$ & $\begin{array}{r}\% \\
20,9 \\
11,3 \\
5,1 \\
4,0 \\
3,5 \\
3,2 \\
3,0 \\
1,5 \\
1,5 \\
1,2 \\
26,7 \\
18,1 \\
100,0\end{array}$ & $\begin{array}{c}1 \\
2 \\
3 \\
4 \\
5 \\
6 \\
7 \\
8 \\
8 \\
10\end{array}$ & 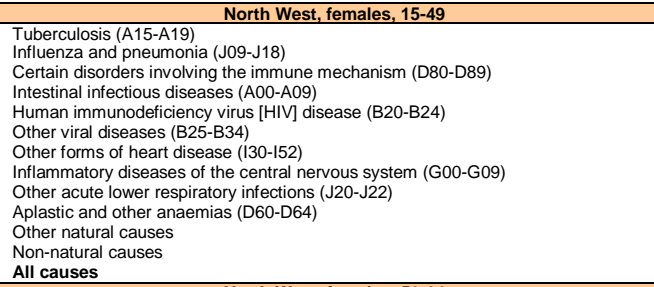 & $\begin{aligned} & \text { No. } \\
& 1565 \\
& 1094 \\
& 492 \\
& 452 \\
& 424 \\
& 350 \\
& 282 \\
& 147 \\
& 147 \\
& 122 \\
& 2734 \\
& 372 \\
& 8181 \\
&\end{aligned}$ & $\begin{array}{r}5,5 \\
5,2 \\
4,3 \\
3,4 \\
1,8 \\
1,8 \\
1,5 \\
33,4 \\
4,5 \\
100,0 \\
\end{array}$ \\
\hline $\begin{array}{l}2 \\
3 \\
4 \\
5 \\
6 \\
7 \\
8 \\
9\end{array}$ & 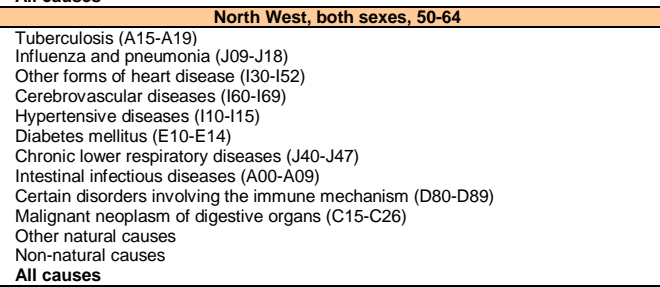 & $\begin{array}{l}\text { No. } \\
994 \\
571 \\
528 \\
406 \\
382 \\
351 \\
305 \\
240 \\
192 \\
170 \\
3075 \\
381 \\
7595\end{array}$ & $\begin{array}{r}\% \\
13,1 \\
7,5 \\
7,0 \\
5,3 \\
5,0 \\
4,6 \\
4,0 \\
3,2 \\
2,5 \\
2,2 \\
40,5 \\
5,0 \\
100,0\end{array}$ & & 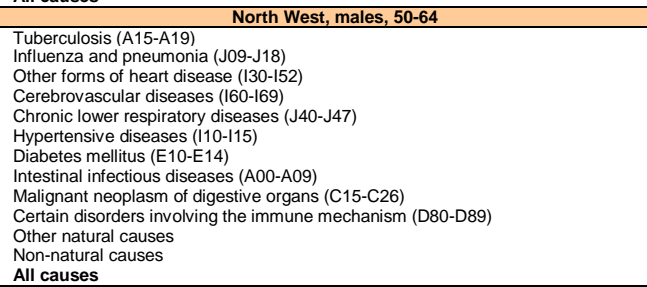 & $\begin{array}{l}\text { No. } \\
678 \\
360 \\
312 \\
237 \\
193 \\
174 \\
156 \\
130 \\
120 \\
111 \\
1818 \\
306 \\
4595\end{array}$ & 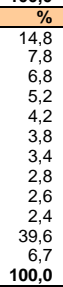 & $\begin{array}{l}2 \\
3 \\
4 \\
5 \\
6 \\
7 \\
8 \\
9 \\
10\end{array}$ & 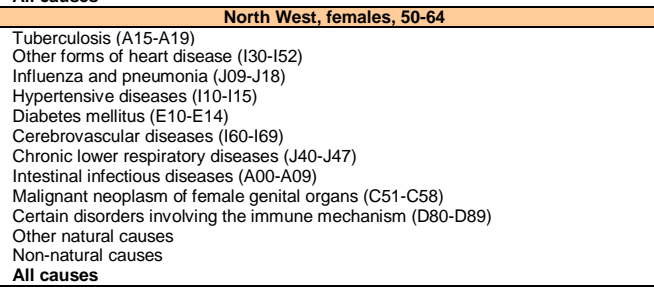 & $\begin{aligned} & \text { No. } \\
& 316 \\
& 216 \\
& 210 \\
& 208 \\
& 194 \\
& 168 \\
& 111 \\
& 108 \\
& 91 \\
& 81 \\
& 1212 \\
& 75 \\
& 2990\end{aligned}$ & $\begin{array}{r}7,2 \\
7,0 \\
7,0 \\
6,5 \\
5,6 \\
3,7 \\
3,6 \\
3,0 \\
2,7 \\
4,0,5 \\
2,5 \\
10,0,0\end{array}$ \\
\hline $\begin{array}{l}2 \\
3 \\
4 \\
5 \\
6 \\
7\end{array}$ & 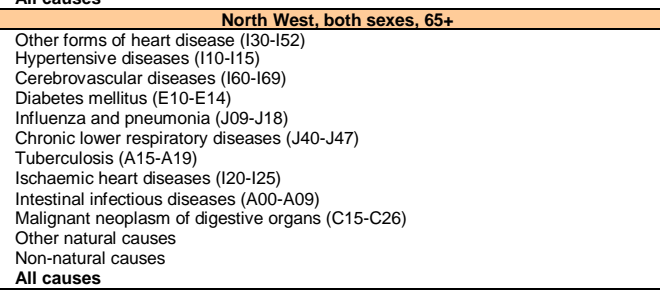 & $\begin{array}{r}\text { No. } \\
1163 \\
997 \\
945 \\
545 \\
486 \\
409 \\
378 \\
276 \\
254 \\
180 \\
4276 \\
214 \\
10123\end{array}$ & $\begin{array}{r}\% \\
\% \\
11,5 \\
9,8 \\
9,3 \\
5,4 \\
4,8 \\
4,0 \\
3,7 \\
2,7 \\
2,7 \\
1,8 \\
42,2 \\
2,1 \\
100,0\end{array}$ & & 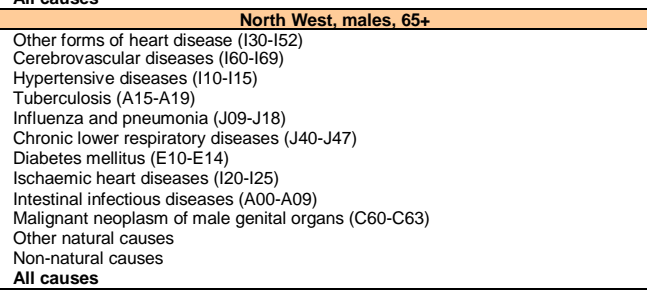 & $\begin{array}{l}\text { No. } \\
514 \\
415 \\
314 \\
268 \\
256 \\
252 \\
220 \\
143 \\
133 \\
116 \\
2058 \\
123 \\
4812\end{array}$ & $\begin{array}{r}\% \\
10,7 \\
8,6 \\
6,5 \\
5,6 \\
5,3 \\
5,2 \\
4,6 \\
3,0 \\
2,0 \\
2,4 \\
42,8 \\
2,6 \\
100,0\end{array}$ & $\begin{array}{l}2 \\
3 \\
4 \\
5 \\
6 \\
7 \\
8 \\
9 \\
10\end{array}$ & 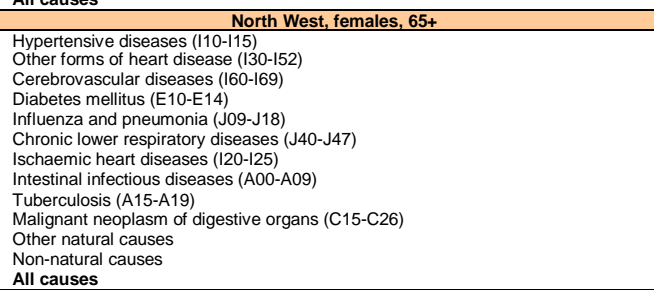 & $\begin{array}{r}\text { No. } \\
683 \\
649 \\
530 \\
325 \\
230 \\
157 \\
133 \\
121 \\
110 \\
79 \\
200 \\
91 \\
5308 \\
\end{array}$ & $\begin{array}{r}12,9 \\
12,2 \\
10,0 \\
6,1 \\
4,3 \\
3,0 \\
2,5 \\
2,3 \\
2,1 \\
1,5 \\
41,4 \\
1,7 \\
100,0\end{array}$ \\
\hline
\end{tabular}

*Including deaths due to MDR-TB and XDR-TB 


\section{Appendix L.7: The ten leading underlying natural causes of death by age and sex: Gauteng, 2009}

\begin{tabular}{|c|c|c|c|c|c|c|c|c|c|c|c|}
\hline $\begin{array}{l}2 \\
3 \\
4 \\
5 \\
6 \\
7 \\
8 \\
9 \\
10\end{array}$ & 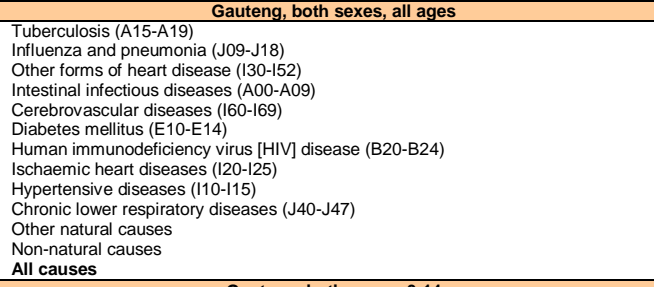 & $\begin{array}{r}\text { No. } \\
10595 \\
9573 \\
65152 \\
4820 \\
4382 \\
3689 \\
3223 \\
2923 \\
2889 \\
2389 \\
53245 \\
10857 \\
114729 \\
\end{array}$ & $\begin{array}{r}\% \\
\%, 2 \\
8,2 \\
5,4 \\
4,2 \\
3,8 \\
3,2 \\
2,2 \\
2,5 \\
2,5 \\
2,1 \\
46,4 \\
9,5 \\
100,0 \\
\end{array}$ & $\begin{array}{l}1 \\
2 \\
3\end{array}$ & 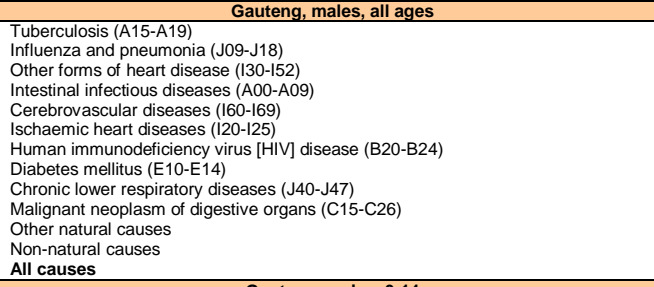 & $\begin{aligned} & \text { No. } \\
& 5943 \\
& 4757 \\
& 2840 \\
& 2282 \\
& 2014 \\
& 1815 \\
& 1664 \\
& 1595 \\
& 1429 \\
& 1265 \\
& 26364 \\
& 8503 \\
& 60471 \\
&\end{aligned}$ & $\begin{array}{rl}\% & 9 \\
9,8 \\
4,9 \\
4,7 \\
3,8 \\
3,3 \\
3,0 \\
2,8 \\
2,6 \\
2,4 \\
2,1 \\
43,6 \\
14,1 \\
100,0 \\
\end{array}$ & 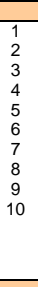 & 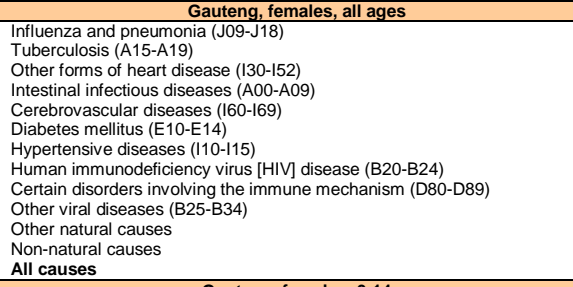 & $\begin{aligned} & \text { No. } 4771 \\
& 4613 \\
& 3295 \\
& 2517 \\
& 2365 \\
& 2093 \\
& 1753 \\
& 1542 \\
& 1130 \\
& 1128 \\
& 26352 \\
& 2327 \\
& 53886 \\
&\end{aligned}$ & $\begin{array}{r}8,9 \\
8,6 \\
6,1 \\
4,7 \\
4,4 \\
3,9 \\
3,3 \\
2,9 \\
2,1 \\
2,1 \\
48,9 \\
4,3 \\
100,0 \\
\end{array}$ \\
\hline $\begin{array}{l}1 \\
2 \\
3 \\
4 \\
5 \\
6 \\
7 \\
8 \\
9 \\
10\end{array}$ & 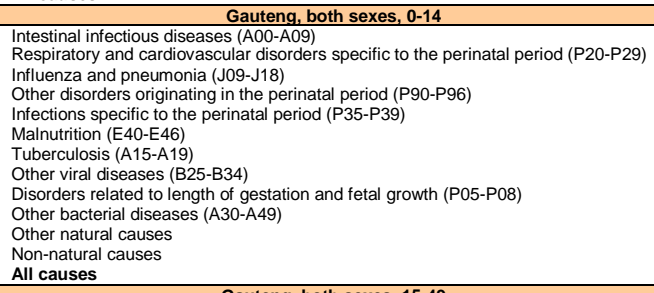 & $\begin{array}{r}\text { No. } \\
1808 \\
1692 \\
1447 \\
503 \\
438 \\
348 \\
296 \\
221 \\
214 \\
212 \\
5140 \\
938 \\
13257 \\
\end{array}$ & $\begin{array}{r}\%, \\
13,6 \\
12,8 \\
10,9 \\
3,8 \\
3,3 \\
2,6 \\
2,2 \\
1,7 \\
1,6 \\
1,6 \\
38,8 \\
7,1 \\
100,0\end{array}$ & $\begin{array}{l}1 \\
2 \\
3 \\
4 \\
5 \\
6 \\
7\end{array}$ & 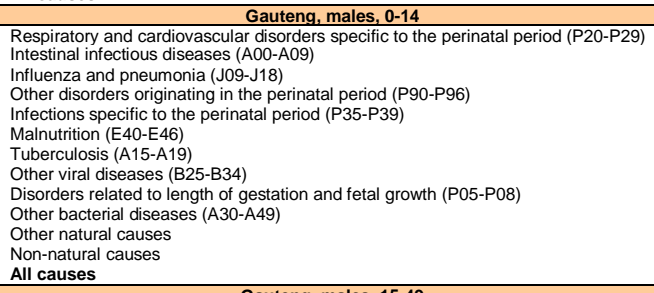 & $\begin{array}{l}\text { No. } \\
961 \\
928 \\
729 \\
274 \\
244 \\
176 \\
170 \\
121 \\
113 \\
112 \\
2708 \\
554 \\
7090 \\
\end{array}$ & $\begin{array}{r}\% \% \\
13,6 \\
13,1 \\
10,3 \\
3,9 \\
3,4 \\
2,5 \\
2,4 \\
1,7 \\
1,6 \\
1,6 \\
38,2 \\
7,2 \\
100,0\end{array}$ & $\begin{array}{l}2 \\
3 \\
4 \\
5 \\
6 \\
7\end{array}$ & 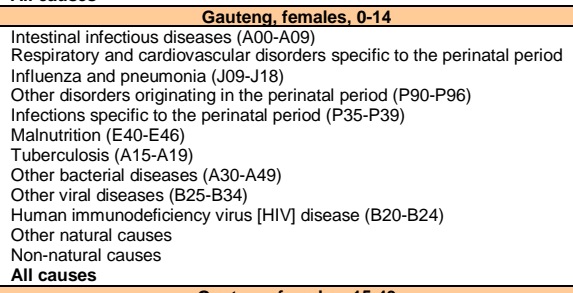 & $\begin{array}{r}\text { No. } \\
868 \\
708 \\
702 \\
220 \\
188 \\
168 \\
125 \\
100 \\
100 \\
98 \\
2381 \\
380 \\
6038 \\
\end{array}$ & $\begin{array}{r}\%, \\
14,4 \\
11,7 \\
11,6 \\
3,6 \\
3,1 \\
2,8 \\
2,1 \\
1,7 \\
1,7 \\
1,6 \\
39,4 \\
6,3 \\
100,0 \\
\end{array}$ \\
\hline $\begin{array}{l}1 \\
2 \\
3 \\
4 \\
5 \\
6 \\
7 \\
8 \\
9 \\
9 \\
10\end{array}$ & 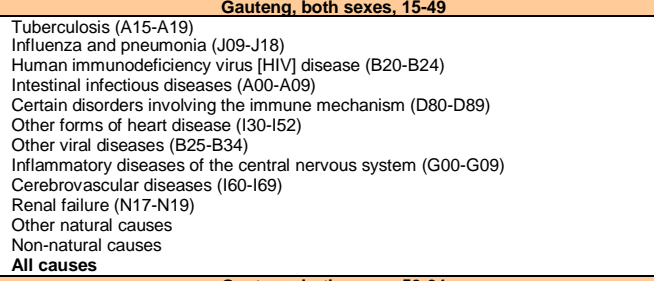 & $\begin{array}{r}\text { No. } \\
7835 \\
5049 \\
2516 \\
1939 \\
1658 \\
1618 \\
1507 \\
1348 \\
826 \\
640 \\
649 \\
7742 \\
49626 \\
\end{array}$ & $\begin{array}{r}\% \\
15,8 \\
10,2 \\
5,1 \\
3,9 \\
3,3 \\
3,3 \\
3,0 \\
2,7 \\
1,7 \\
1,3 \\
34,1 \\
15,6 \\
100,0\end{array}$ & $\begin{array}{l}1 \\
2 \\
3 \\
4\end{array}$ & 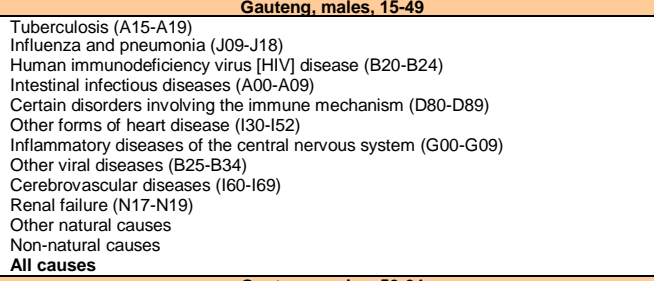 & $\begin{array}{r}\text { No. } \\
4140 \\
2458 \\
1279 \\
877 \\
792 \\
791 \\
658 \\
631 \\
405 \\
348 \\
8323 \\
6430 \\
27132 \\
\end{array}$ & $\begin{array}{r}\% \\
15,3 \\
9,1 \\
4,7 \\
3,2 \\
2,9 \\
2,9 \\
2,4 \\
2,3 \\
1,5 \\
1,3 \\
30,7 \\
23,7 \\
100,0\end{array}$ & $\begin{array}{c}7 \\
8 \\
9 \\
10\end{array}$ & 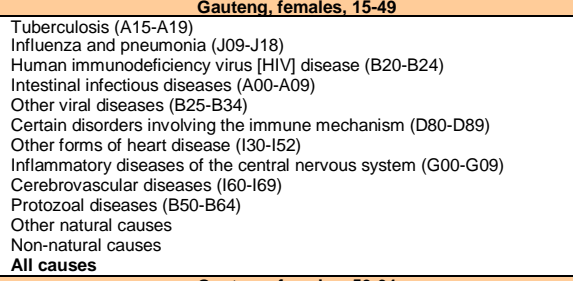 & $\begin{aligned} & \text { No. } \\
& 3673 \\
& 2569 \\
& 1234 \\
& 1056 \\
& 874 \\
& 863 \\
& 818 \\
& 690 \\
& 419 \\
& 345 \\
& 8507 \\
& 1308 \\
& 22356 \\
&\end{aligned}$ & $\begin{array}{r}\% \\
16,4 \\
11,5 \\
5,5 \\
4,7 \\
3,9 \\
3,9 \\
3,7 \\
3,1 \\
1,9 \\
1,5 \\
38,1 \\
5,9 \\
100,0\end{array}$ \\
\hline $\begin{array}{l}2 \\
3 \\
4 \\
5 \\
6 \\
6\end{array}$ & 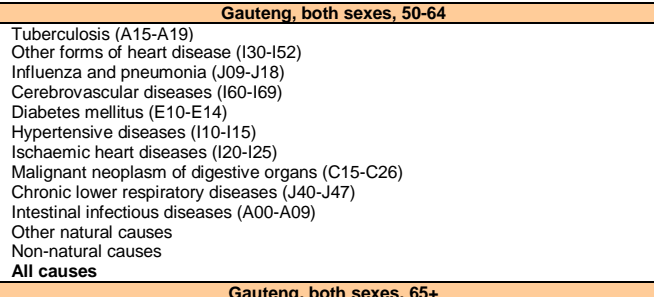 & $\begin{aligned} \text { No. } \\
1906 \\
1485 \\
1443 \\
1203 \\
1157 \\
807 \\
792 \\
718 \\
666 \\
522 \\
10199 \\
1274 \\
22172 \\
\end{aligned}$ & 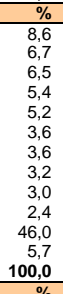 & $\begin{array}{l}2 \\
3 \\
4 \\
5 \\
6\end{array}$ & 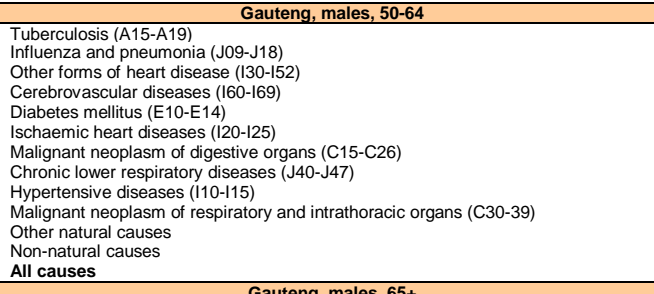 & $\begin{aligned} & \text { No. } \\
& 1287 \\
& 849 \\
& 816 \\
& 676 \\
& 587 \\
& 578 \\
& 469 \\
& 445 \\
& 406 \\
& 302 \\
& 5629 \\
& 1007 \\
& 13051 \\
&\end{aligned}$ & 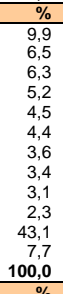 & $\begin{array}{l}6 \\
7\end{array}$ & 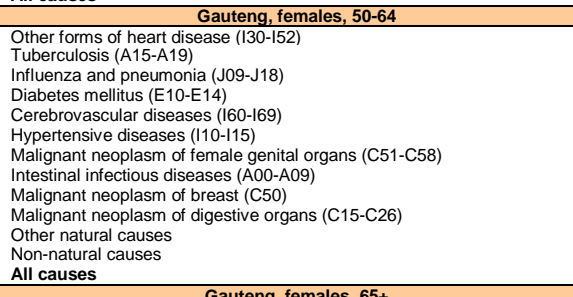 & $\begin{array}{l}\text { No. } \\
665 \\
615 \\
591 \\
569 \\
527 \\
401 \\
339 \\
274 \\
266 \\
249 \\
4329 \\
267 \\
9092 \\
\end{array}$ & $\begin{array}{r}6,8 \\
6,5 \\
6,3 \\
5,8 \\
4,4 \\
3,7 \\
3,0 \\
2,9 \\
2,7 \\
47,6 \\
2,9 \\
100,0 \\
\end{array}$ \\
\hline $\begin{array}{l}2 \\
2 \\
3 \\
4 \\
5\end{array}$ & 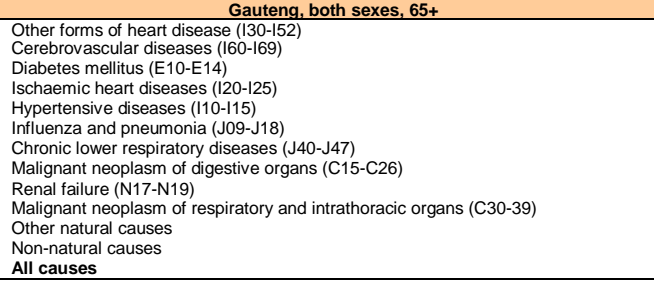 & $\begin{aligned} & \text { No. } \\
& 2839 \\
& 2337 \\
& 1974 \\
& 1737 \\
& 1663 \\
& 1592 \\
& 1210 \\
& 1068 \\
& 684 \\
& 566 \\
& 12873 \\
& 801 \\
& 29344 \\
&\end{aligned}$ & $\begin{array}{r}\% \\
9,7 \\
8,0 \\
6,7 \\
5,9 \\
5,7 \\
5,4 \\
4,1 \\
3,6 \\
2,3 \\
1,9 \\
43,9 \\
2,7 \\
100,0\end{array}$ & $\begin{array}{c}2 \\
3 \\
4 \\
5 \\
6 \\
7 \\
8 \\
9 \\
10\end{array}$ & 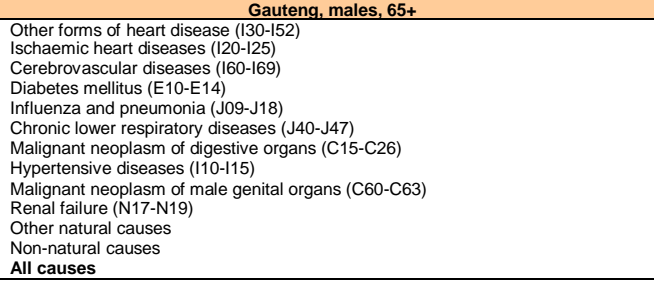 & $\begin{array}{r}\text { No. } \\
1122 \\
966 \\
922 \\
737 \\
697 \\
688 \\
598 \\
522 \\
446 \\
351 \\
5507 \\
437 \\
12993 \\
\end{array}$ & $\begin{array}{r}8,6 \\
7,4 \\
7,1 \\
5,7 \\
5,4 \\
5,3 \\
4,6 \\
4,0 \\
3,4 \\
2,7 \\
42,4 \\
3,4 \\
100,0 \\
\end{array}$ & 10 & 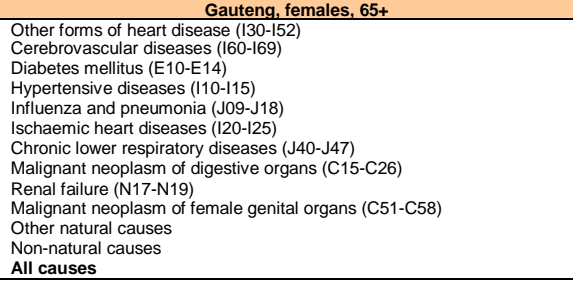 & $\begin{array}{r}\text { No. } \\
1715 \\
1415 \\
1237 \\
1141 \\
895 \\
770 \\
522 \\
470 \\
332 \\
326 \\
7153 \\
362 \\
16338 \\
\end{array}$ & $\begin{array}{r}10,5 \\
8,7 \\
7,6 \\
7,0 \\
5,0 \\
4,7 \\
3,2 \\
2,9 \\
2,0 \\
2,0 \\
43,8 \\
2,2 \\
100,0\end{array}$ \\
\hline
\end{tabular}

* Including deaths due to MDR-TB and XDR-TB 
Appendix L.8: The ten leading underlying natural causes of death by age and sex: Mpumalanga, 2009

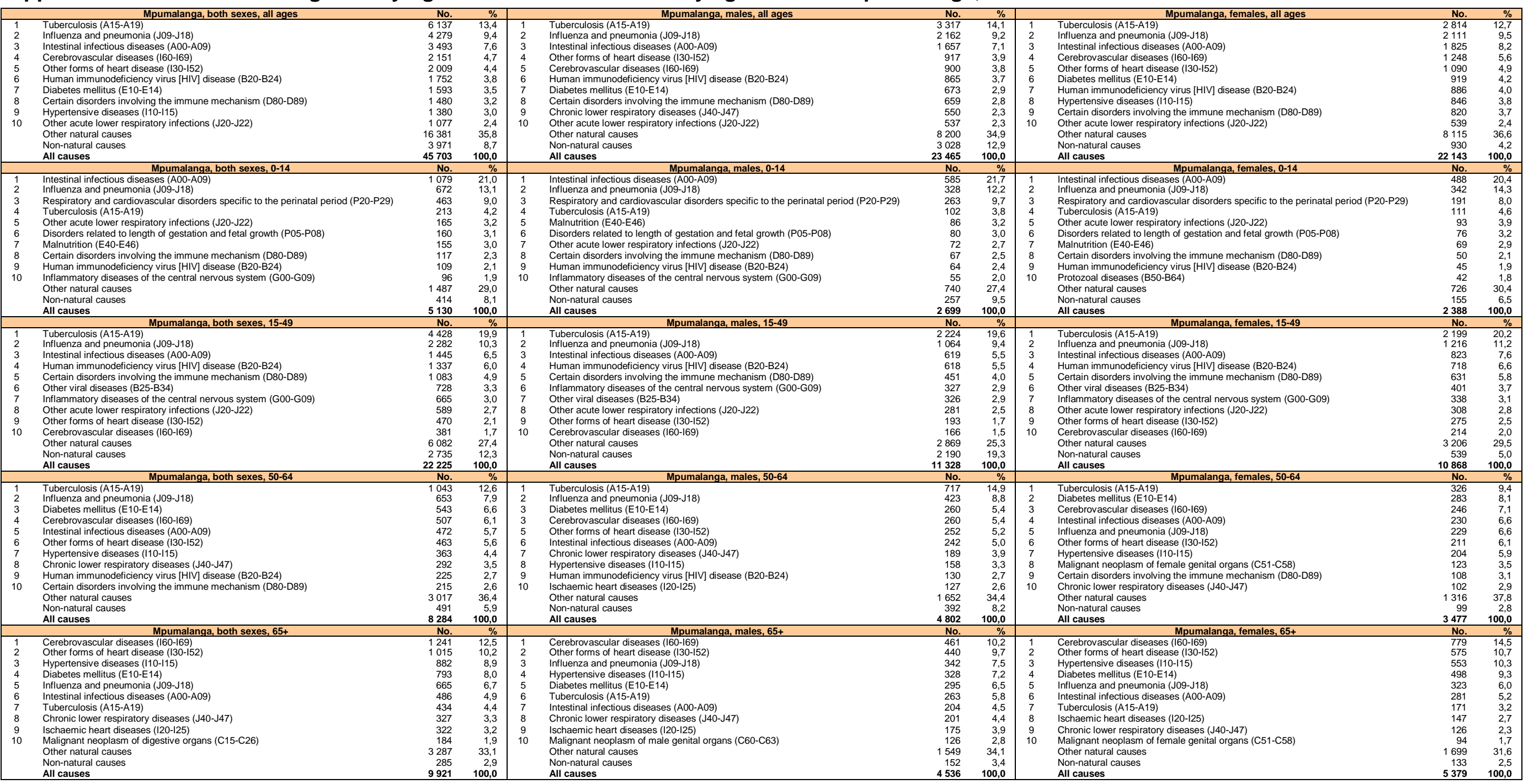

"Including deaths due to MDR-TB and XDR-TB 


\section{Appendix L.9: The ten leading underlying natural causes of death by age and sex: Limpopo, 2009}

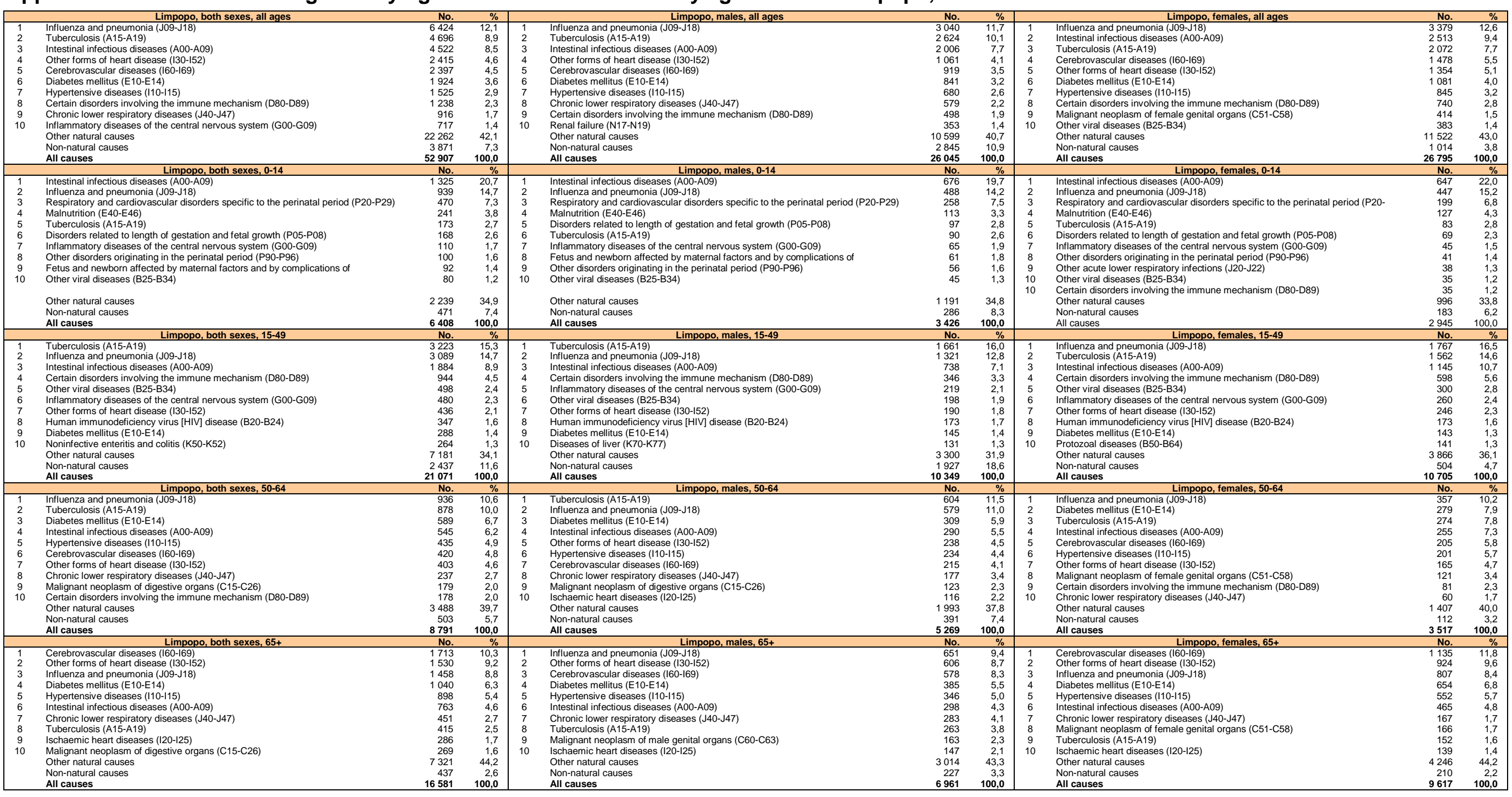


Appendix M: Number of deaths by main groups of causes of death and district municipality of death occurrence (Western Cape, Eastern Cape and Northern Cape), 2009

\begin{tabular}{|c|c|c|c|c|c|c|c|c|c|c|c|c|c|}
\hline & & $\begin{array}{c}\text { Certain } \\
\text { infectious } \\
\text { and } \\
\text { parasitic } \\
\text { diseases } \\
\end{array}$ & Neoplasms & $\begin{array}{l}\text { Diseases of } \\
\text { blood and } \\
\text { immune } \\
\text { mechanism }\end{array}$ & $\begin{array}{c}\text { Endocrine, } \\
\text { nutritional } \\
\text { and } \\
\text { metabolic } \\
\text { diseases }\end{array}$ & $\begin{array}{l}\text { Diseases } \\
\text { of the } \\
\text { nervous } \\
\text { system }\end{array}$ & $\begin{array}{l}\text { Diseases } \\
\text { of the } \\
\text { circulatory } \\
\text { system }\end{array}$ & $\begin{array}{c}\text { Diseases } \\
\text { of the } \\
\text { respiratory } \\
\text { system } \\
\end{array}$ & $\begin{array}{l}\text { Diseases } \\
\text { of the } \\
\text { digestive } \\
\text { system }\end{array}$ & $\begin{array}{c}\text { Perinatal } \\
\text { conditions }\end{array}$ & $\begin{array}{c}\text { External } \\
\text { causes of } \\
\text { morbidity } \\
\text { and } \\
\text { mortality }\end{array}$ & & \\
\hline $\begin{array}{l}\text { Province of } \\
\text { death } \\
\text { occurrence }\end{array}$ & $\begin{array}{l}\text { District Municipality of death } \\
\text { occurrence }\end{array}$ & A00-B99 & C00-D48 & D50-D89 & E00-E90 & G00-G99 & $100-199$ & J00-J99 & K00-K93 & P00-P96 & V01-Y98 & $\begin{array}{c}\text { Other } \\
\text { causes }\end{array}$ & Total \\
\hline \multirow{8}{*}{$\begin{array}{l}\text { Western } \\
\text { Cape }\end{array}$} & Cape Winelands & 1233 & 926 & 48 & 422 & 145 & 1143 & 610 & 148 & 125 & 810 & 730 & 6340 \\
\hline & Central Karoo & 159 & 97 & 21 & 31 & 8 & 164 & 102 & 17 & 21 & 146 & 96 & 862 \\
\hline & City of Cape Town Metro & 5325 & 4606 & 273 & 2292 & 696 & 5464 & 2136 & 632 & 621 & 3204 & 3288 & 28537 \\
\hline & Eden & 914 & 826 & 82 & 271 & 126 & 1084 & 505 & 117 & 93 & 540 & 499 & 5057 \\
\hline & Overberg & 246 & 305 & 7 & 95 & 44 & 358 & 145 & 50 & 25 & 248 & 168 & 1691 \\
\hline & West Coast & 531 & 410 & 50 & 177 & 73 & 609 & 293 & 70 & 56 & 332 & 297 & 2898 \\
\hline & Unspecified & 4 & 1 & 0 & 0 & 1 & 1 & 1 & 0 & 0 & 2 & 3 & 13 \\
\hline & Total & 8412 & 7171 & 481 & 3288 & 1093 & 8823 & 3792 & 1034 & 941 & 5282 & 5081 & 45398 \\
\hline \multirow{9}{*}{ Eastern Cape } & Alfred Nzo & 1738 & 138 & 206 & 181 & 213 & 571 & 1025 & 113 & 28 & 738 & 4523 & 9474 \\
\hline & Amathole & 3902 & 732 & 375 & 641 & 587 & 2323 & 2359 & 286 & 103 & 1222 & 3031 & 15561 \\
\hline & Cacadu & 1138 & 366 & 143 & 197 & 93 & 879 & 518 & 95 & 82 & 477 & 885 & 4873 \\
\hline & Chris Hani & 2430 & 564 & 352 & 428 & 334 & 1373 & 1614 & 244 & 82 & 766 & 1223 & 9410 \\
\hline & Joe Gqabi & 1528 & 168 & 250 & 196 & 138 & 733 & 913 & 115 & 37 & 353 & 1111 & 5542 \\
\hline & Nelson Mandela Bay Metro & 3462 & 1461 & 487 & 1015 & 397 & 2441 & 1384 & 458 & 195 & 1305 & 1447 & 14052 \\
\hline & O.R.Tambo & 2929 & 424 & 289 & 382 & 362 & 891 & 1102 & 301 & 54 & 1061 & 3657 & 11452 \\
\hline & Unspecified & 5 & 1 & 1 & 0 & 0 & 0 & 0 & 1 & 0 & 2 & 3 & 13 \\
\hline & Total & 20261 & 5119 & 2383 & 3720 & 2429 & 11151 & 10261 & 1946 & 663 & 7216 & 16983 & 82132 \\
\hline \multirow{6}{*}{$\begin{array}{l}\text { Northern } \\
\text { Cape }\end{array}$} & Frances Baard & 1113 & 408 & 203 & 210 & 107 & 640 & 533 & 140 & 93 & 361 & 679 & 4487 \\
\hline & John Taolo Gaetsewe & 477 & 85 & 39 & 73 & 47 & 228 & 454 & 45 & 102 & 162 & 1032 & 2744 \\
\hline & Namakwa & 131 & 139 & 22 & 83 & 20 & 243 & 157 & 32 & 17 & 129 & 126 & 1099 \\
\hline & Pixley ka Seme & 607 & 201 & 96 & 162 & 50 & 469 & 418 & 77 & 86 & 223 & 252 & 2641 \\
\hline & Siyanda & 1093 & 396 & 141 & 221 & 78 & 641 & 495 & 110 & 86 & 400 & 450 & 4111 \\
\hline & Total & 3421 & 1229 & 501 & 749 & 302 & 2221 & 2057 & 404 & 384 & 1275 & 2539 & 15082 \\
\hline
\end{tabular}


Appendix M.1: Number of deaths by main groups of causes of death and district municipality of death occurrence (Free State, KwaZulu-Natal and North West), 2009

\begin{tabular}{|c|c|c|c|c|c|c|c|c|c|c|c|c|c|}
\hline & & $\begin{array}{c}\text { Certain } \\
\text { infectious } \\
\text { and } \\
\text { parasitic } \\
\text { diseases }\end{array}$ & Neoplasms & $\begin{array}{c}\text { Diseases of } \\
\text { blood and } \\
\text { immune } \\
\text { mechanism }\end{array}$ & $\begin{array}{c}\text { Endocrine, } \\
\text { nutritional } \\
\text { and } \\
\text { metabolic } \\
\text { diseases }\end{array}$ & $\begin{array}{c}\text { Diseases } \\
\text { of the } \\
\text { nervous } \\
\text { system }\end{array}$ & $\begin{array}{l}\text { Diseases } \\
\text { of the } \\
\text { circulatory } \\
\text { system }\end{array}$ & $\begin{array}{c}\text { Diseases } \\
\text { of the } \\
\text { respiratory } \\
\text { system }\end{array}$ & $\begin{array}{l}\text { Diseases } \\
\text { of the } \\
\text { digestive } \\
\text { system }\end{array}$ & $\begin{array}{l}\text { Perinatal } \\
\text { conditions }\end{array}$ & $\begin{array}{c}\text { External } \\
\text { causes of } \\
\text { morbidity } \\
\text { and } \\
\text { mortality } \\
\end{array}$ & & \\
\hline $\begin{array}{l}\text { Province of } \\
\text { death } \\
\text { occurrence }\end{array}$ & $\begin{array}{l}\text { District Municipality of death } \\
\text { occurrence }\end{array}$ & A00-B99 & C00-D48 & D50-D89 & E00-E90 & G00-G99 & $100-199$ & J00-J99 & K00-K93 & P00-P96 & V01-Y98 & $\begin{array}{c}\text { Other } \\
\text { causes }\end{array}$ & Total \\
\hline & Fezile Dabi & 1776 & 322 & 445 & 505 & 162 & 1206 & 1265 & 172 & 201 & 576 & 529 & 7159 \\
\hline & Lejweleputswa & 2768 & 387 & 592 & 554 & 292 & 1493 & 2348 & 249 & 279 & 733 & 1681 & 11376 \\
\hline & Mangaung Metro & 2754 & 929 & 451 & 545 & 255 & 1494 & 1567 & 310 & 298 & 900 & 3828 & 13331 \\
\hline Free State & Thabo Mofutsanyane & 3127 & 426 & 947 & 740 & 356 & 2187 & 2786 & 387 & 389 & 747 & 1087 & 13179 \\
\hline & Xhariep & 506 & 115 & 134 & 89 & 32 & 297 & 394 & 38 & 39 & 172 & 400 & 2216 \\
\hline & Unspecified & 0 & 0 & 0 & 0 & 0 & 1 & 0 & 1 & 2 & 0 & 0 & 4 \\
\hline & Total & 10931 & 2179 & 2569 & 2433 & 1097 & 6678 & 8360 & 1157 & 1208 & 3128 & 7525 & 47265 \\
\hline & Amajuba & 1841 & 231 & 197 & 365 & 206 & 981 & 1452 & 186 & 169 & 408 & 568 & 6604 \\
\hline & eThekwini Metro & 10800 & 2377 & 586 & 2265 & 1130 & 5843 & 3636 & 1007 & 749 & 3738 & 7234 & 39365 \\
\hline & iLembe & 2527 & 204 & 146 & 387 & 168 & 874 & 546 & 170 & 146 & 632 & 920 & 6720 \\
\hline & Ugu & 3986 & 467 & 318 & 680 & 275 & 1828 & 1588 & 232 & 219 & 930 & 1466 & 11989 \\
\hline & UMgungundlovu & 4177 & 798 & 246 & 782 & 397 & 2109 & 1494 & 414 & 141 & 1226 & 2035 & 13819 \\
\hline KwaZulu- & Umkhanyakude & 2404 & 215 & 92 & 202 & 110 & 661 & 389 & 85 & 111 & 462 & 1625 & 6356 \\
\hline & Umzinyathi & 2036 & 187 & 76 & 283 & 129 & 750 & 586 & 108 & 186 & 508 & 1359 & 6208 \\
\hline & Uthukela & 2837 & 297 & 378 & 451 & 290 & 1465 & 1141 & 208 & 198 & 803 & 733 & 8801 \\
\hline & Uthungulu & 4238 & 412 & 318 & 618 & 300 & 1398 & 1052 & 270 & 423 & 1000 & 1546 & 11575 \\
\hline & Zululand & 3267 & 211 & 232 & 370 & 287 & 937 & 1051 & 206 & 247 & 600 & 1530 & 8938 \\
\hline & Unspecified & 683 & 41 & 44 & 98 & 89 & 183 & 238 & 60 & 57 & 167 & 731 & 2391 \\
\hline & Total & 40414 & 5572 & 2732 & 6729 & 3488 & 17496 & 13748 & 3024 & 2739 & 10799 & 20628 & 127369 \\
\hline & Bojanala & 2984 & 539 & 690 & 668 & 224 & 2281 & 1782 & 270 & 338 & 1134 & 2910 & 13820 \\
\hline & Dr Kenneth Kaunda & 2777 & 656 & 288 & 365 & 227 & 1256 & 1136 & 274 & 283 & 766 & 1234 & 9262 \\
\hline 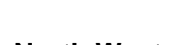 & Dr Ruth Segomotsi Mompati & 1855 & 253 & 275 & 275 & 114 & 935 & 1128 & 137 & 222 & 353 & 955 & 6502 \\
\hline Nortn vvest & Ngaka Modiri Molema & 2527 & 319 & 341 & 525 & 268 & 1715 & 2347 & 205 & 444 & 634 & 1452 & 10777 \\
\hline & Unspecified & 1 & 0 & 0 & 0 & 0 & 2 & 1 & 0 & 0 & 3 & 4 & 11 \\
\hline
\end{tabular}




\section{Appendix M.2: Number of deaths by main groups of causes of death and district municipality of death occurrence (Gauteng, Mpumalanga and} Limpopo), 2009

\begin{tabular}{|c|c|c|c|c|c|c|c|c|c|c|c|c|c|}
\hline & & $\begin{array}{l}\text { Certain } \\
\text { infectious } \\
\text { and } \\
\text { parasitic } \\
\text { diseases }\end{array}$ & Neoplasms & $\begin{array}{l}\text { Diseases of } \\
\text { blood and } \\
\text { immune } \\
\text { mechanism }\end{array}$ & $\begin{array}{c}\text { Endocrine, } \\
\text { nutritional } \\
\text { and } \\
\text { metabolic } \\
\text { diseases }\end{array}$ & $\begin{array}{l}\text { Diseases } \\
\text { of the } \\
\text { nervous } \\
\text { system }\end{array}$ & $\begin{array}{l}\text { Diseases } \\
\text { of the } \\
\text { circulatory } \\
\text { system }\end{array}$ & $\begin{array}{l}\text { Diseases } \\
\text { of the } \\
\text { respiratory } \\
\text { system }\end{array}$ & $\begin{array}{l}\text { Diseases } \\
\text { of the } \\
\text { digestive } \\
\text { system }\end{array}$ & $\begin{array}{l}\text { Perinatal } \\
\text { conditions }\end{array}$ & $\begin{array}{l}\text { External } \\
\text { causes of } \\
\text { morbidity } \\
\text { and } \\
\text { mortality }\end{array}$ & & \\
\hline $\begin{array}{l}\text { Province of } \\
\text { death } \\
\text { occurrence }\end{array}$ & $\begin{array}{l}\text { District Municipality of death } \\
\text { occurrence }\end{array}$ & A00-B99 & C00-D48 & D50-D89 & E00-E90 & G00-G99 & $100-199$ & J00-J99 & K00-K93 & P00-P96 & V01-Y98 & $\begin{array}{c}\text { Other } \\
\text { causes }\end{array}$ & Total \\
\hline \multirow{7}{*}{ Gauteng } & City of Johannesburg Metro & 7296 & 3437 & 841 & 1546 & 899 & 5250 & 3833 & 918 & 1062 & 3584 & 8291 & 36957 \\
\hline & City of Tshwane Metro & 5377 & 2791 & 852 & 1708 & 707 & 5591 & 3271 & 822 & 581 & 2669 & 2325 & 26694 \\
\hline & Ekurhuleni Metro & 6821 & 1598 & 776 & 1248 & 1016 & 3869 & 4233 & 747 & 1159 & 2743 & 6361 & 30571 \\
\hline & Sedibeng & 2252 & 591 & 283 & 599 & 370 & 2066 & 1972 & 280 & 323 & 869 & 1003 & 10608 \\
\hline & West Rand & 2159 & 372 & 331 & 409 & 369 & 1233 & 1563 & 221 & 257 & 991 & 1958 & 9863 \\
\hline & Unspecified & 8 & 1 & 0 & 2 & 2 & 6 & 2 & 0 & 1 & 1 & 13 & 36 \\
\hline & Total & 23913 & 8790 & 3083 & 5512 & 3363 & 18015 & 14874 & 2988 & 3383 & 10857 & 19951 & 114729 \\
\hline \multirow{4}{*}{ Mpumalanga } & Ehlanzeni & 6546 & 835 & 707 & 931 & 623 & 2557 & 2406 & 655 & 316 & 1523 & 1731 & 18830 \\
\hline & Gert Sibande & 4317 & 466 & 677 & 734 & 392 & 1771 & 2315 & 429 & 418 & 1081 & 1638 & 14238 \\
\hline & Nkangala & 2823 & 457 & 466 & 733 & 379 & 2153 & 2497 & 300 & 231 & 1362 & 1208 & 12609 \\
\hline & Total & 13692 & 1758 & 1850 & 2398 & 1394 & 6482 & 7219 & 1384 & 965 & 3971 & 4590 & 45703 \\
\hline \multirow{7}{*}{ Limpopo } & Capricorn & 3382 & 822 & 438 & 812 & 339 & 2306 & 2451 & 534 & 263 & 1138 & 2574 & 15059 \\
\hline & Greater Sekhukhune & 2460 & 353 & 398 & 584 & 240 & 2188 & 2997 & 384 & 143 & 757 & 996 & 11500 \\
\hline & Mopani & 2542 & 311 & 308 & 521 & 300 & 1174 & 1312 & 363 & 230 & 739 & 3343 & 11143 \\
\hline & Vhembe & 2126 & 485 & 217 & 627 & 199 & 775 & 917 & 319 & 202 & 701 & 3375 & 9943 \\
\hline & Waterberg & 1110 & 263 & 221 & 219 & 92 & 672 & 708 & 91 & 125 & 534 & 1209 & 5244 \\
\hline & Unspecified & 2 & 0 & 0 & 0 & 0 & 7 & 1 & 0 & 0 & 2 & 6 & 18 \\
\hline & Total & 11622 & 2234 & 1582 & 2763 & 1170 & 7122 & 8386 & 1691 & 963 & 3871 & 11503 & 52907 \\
\hline
\end{tabular}




\section{Appendix N: The ten leading underlying natural causes of death by district municipality of death occurrence, Western Cape, 2009}

\begin{tabular}{|c|c|c|c|c|c|c|c|c|c|c|c|}
\hline \multicolumn{2}{|r|}{ Cape Winelands } & \multirow{2}{*}{ No. } & \multirow{2}{*}{$\begin{aligned} \% \\
9,0\end{aligned}$} & \multicolumn{2}{|r|}{ Central Karoo } & \multirow{2}{*}{$\begin{aligned} \text { No. } \\
97\end{aligned}$} & \multirow{2}{*}{$\begin{aligned} \% \\
11,3\end{aligned}$} & & \multirow{2}{*}{$\begin{aligned} \text { No. } \\
2368\end{aligned}$} & \multirow{2}{*}{$\begin{aligned} \% \\
8,3\end{aligned}$} \\
\hline 1 & Tuberculosis (A15-A19) & & & 1 & Tuberculosis (A15-A19) & & & 1 & $\begin{array}{l}\text { City of Cape Town Metro } \\
\text { Tuberculosis (A15-A19) }\end{array}$ & & \\
\hline 2 & Chronic lower respiratory diseases (J40-J47) & 390 & 6,2 & 2 & Chronic lower respiratory diseases (J40-J47) & 62 & 7,2 & 2 & Diabetes mellitus (E10-E14) & 1978 & 6,9 \\
\hline 3 & Diabetes mellitus (E10-E14) & 356 & 5,6 & 3 & Cerebrovascular diseases (160-169) & 53 & 6,1 & 3 & Ischaemic heart diseases (I20-125) & 1773 & 6,2 \\
\hline 4 & Cerebrovascular diseases (160-169) & 338 & 5,3 & 4 & Other forms of heart disease (130-152) & 49 & 5,7 & 4 & $\begin{array}{l}\text { Human immunodeficiency virus [HIV] disease } \\
\text { (B20-B24) }\end{array}$ & 1656 & 5,8 \\
\hline 5 & Ischaemic heart diseases (I20-125) & 336 & 5,3 & 5 & Ischaemic heart diseases (120-125) & 29 & 3,4 & 5 & Cerebrovascular diseases (160-169) & 1262 & 4,4 \\
\hline 6 & $\begin{array}{l}\text { Human immunodeficiency virus [HIV] disease } \\
\text { (B20-B24) }\end{array}$ & 333 & 5,3 & 6 & $\begin{array}{l}\text { Human immunodeficiency virus [HIV] disease } \\
\text { (B20-B24) }\end{array}$ & 24 & 2,8 & 6 & Malignant neoplasm of digestive organs (C15-C26) & 1177 & 4,1 \\
\hline 7 & Malignant neoplasm of digestive organs (C15-C26) & 255 & 4,0 & 6 & Diabetes mellitus (E10-E14) & 24 & 2,8 & 7 & Hypertensive diseases (110-115) & 1085 & 3,8 \\
\hline 8 & $\begin{array}{l}\text { Malignant neoplasm of respiratory and intrathoracic } \\
\text { organs (C30-39) }\end{array}$ & 244 & 3,8 & 6 & Hypertensive diseases (110-115) & 24 & 2,8 & 8 & $\begin{array}{l}\text { Malignant neoplasm of respiratory and } \\
\text { intrathoracic organs (C30-39) }\end{array}$ & 1039 & 3,6 \\
\hline 9 & Hypertensive diseases (110-115) & 191 & 3,0 & 9 & Influenza and pneumonia (J09-J18) & 24 & 2,8 & 9 & Chronic lower respiratory diseases (J40-J47) & 1014 & 3,6 \\
\hline 10 & Other forms of heart disease (130-152) & 174 & 2,7 & 10 & $\begin{array}{l}\text { Malignant neoplasm of respiratory and } \\
\text { intrathoracic organs (C30-39) }\end{array}$ & 21 & 2,4 & 10 & Other forms of heart disease (130-152) & 951 & 3,3 \\
\hline & Other natural causes & 2341 & 36,9 & & Other natural causes & 309 & 35,8 & & Other natural causes & 11030 & 38,7 \\
\hline & Non-natural causes & 810 & 12,8 & & Non-natural causes & 146 & 16,9 & & Non-natural causes & 3204 & 11,2 \\
\hline & All causes & 6340 & 100,0 & & All causes & 862 & 100,0 & & All causes & 28537 & 100,0 \\
\hline & Eden & No. & $\%$ & & Overberg & No. & $\%$ & & West Coast & No. & $\%$ \\
\hline 1 & Tuberculosis (A15-A19) & 550 & 10,9 & 1 & Tuberculosis (A15-A19) & 111 & 6,6 & 1 & Tuberculosis (A15-A19) & 341 & 11,8 \\
\hline 2 & Ischaemic heart diseases (120-125) & 321 & 6,3 & 2 & Cerebrovascular diseases (160-169) & 109 & 6,4 & 2 & Ischaemic heart diseases (I20-125) & 210 & 7,2 \\
\hline 3 & Cerebrovascular diseases (160-169) & 317 & 6,3 & 3 & Ischaemic heart diseases (120-125) & 106 & 6,3 & 3 & Cerebrovascular diseases (160-169) & 194 & 6,7 \\
\hline 4 & Chronic lower respiratory diseases (J40-J47) & 281 & 5,6 & 4 & Diabetes mellitus (E10-E14) & 79 & 4,7 & 4 & Chronic lower respiratory diseases (J40-J47) & 159 & 5,5 \\
\hline 5 & Diabetes mellitus (E10-E14) & 235 & 4,6 & 5 & $\begin{array}{l}\text { Human immunodeficiency virus [HIV] disease } \\
\text { (B20-B24) }\end{array}$ & 78 & 4,6 & 5 & Diabetes mellitus (E10-E14) & 152 & 5,2 \\
\hline 6 & Other forms of heart disease (130-152) & 204 & 4,0 & 5 & Chronic lower respiratory diseases (J40-J47) & 78 & 4,6 & 6 & $\begin{array}{l}\text { Malignant neoplasm of respiratory and } \\
\text { intrathoracic organs (C30-39) }\end{array}$ & 101 & 3,5 \\
\hline 7 & Malignant neoplasm of digestive organs (C15-C26) & 202 & 4,0 & 7 & $\begin{array}{l}\text { Malignant neoplasm of respiratory and } \\
\text { intrathoracic organs (C30-39) }\end{array}$ & 77 & 4,6 & 7 & Malignant neoplasm of digestive organs (C15-C26) & 97 & 3,3 \\
\hline 8 & $\begin{array}{l}\text { Malignant neoplasm of respiratory and intrathoracic } \\
\text { organs (C30-39) }\end{array}$ & 183 & 3,6 & 8 & Malignant neoplasm of digestive organs (C15-C26) & 75 & 4,4 & 8 & Influenza and pneumonia (J09-J18) & 92 & 3,2 \\
\hline 9 & $\begin{array}{l}\text { Human immunodeficiency virus [HIV] disease } \\
\text { (B20-B24) }\end{array}$ & 177 & 3,5 & 9 & Other forms of heart disease (130-152) & 67 & 4,0 & 9 & Other forms of heart disease (130-152) & 89 & 3,1 \\
\hline 10 & Influenza and pneumonia (J09-J18) & 160 & 3,2 & 10 & Influenza and pneumonia (J09-J18) & 51 & 3,0 & 10 & $\begin{array}{l}\text { Human immunodeficiency virus [HIV] disease } \\
\text { (B20-B24) }\end{array}$ & 79 & 2,7 \\
\hline & Other natural causes & 1887 & 37,3 & & Other natural causes & 612 & 36,2 & & Other natural causes & 1052 & 36,3 \\
\hline & Non-natural causes & 540 & 10,7 & & Non-natural causes & 248 & 14,7 & & Non-natural causes & 332 & 11,5 \\
\hline & All causes & 5057 & 100,0 & & All causes & 1691 & 100,0 & & All causes & 2898 & 100,0 \\
\hline
\end{tabular}




\section{Appendix N.1: The ten leading underlying natural causes of death by district municipality of death occurrence, Eastern Cape, 2009}

\begin{tabular}{|c|c|c|c|c|c|c|c|c|c|c|c|}
\hline \multicolumn{2}{|r|}{ Alfred Nzo } & No. & $\%$ & \multicolumn{2}{|r|}{ Amathole } & \multirow{2}{*}{$\frac{\text { No. }}{1747}$} & \multirow{2}{*}{$\begin{array}{r}\% \\
11,2\end{array}$} & \multicolumn{2}{|r|}{ Buffalo City Metro } & \multirow{2}{*}{$\frac{\text { No. }}{2029}$} & \multirow{2}{*}{$\begin{array}{r}\% \\
17,3\end{array}$} \\
\hline 1 & Tuberculosis (A15-A19) & 819 & 8,6 & 1 & Tuberculosis (A15-A19) & & & 1 & Tuberculosis (A15-A19) & & \\
\hline 2 & Other diseases of the respiratory system (J95-J99) & 416 & 4,4 & 2 & Chronic lower respiratory diseases (J40-J47) & 967 & 6,2 & 2 & Cerebrovascular diseases (160-169) & 582 & 5,0 \\
\hline 3 & Intestinal infectious diseases (A00-A09) & 414 & 4,4 & 3 & Other forms of heart disease (130-152) & 886 & 5,7 & 3 & Other forms of heart disease (130-152) & 581 & 4,9 \\
\hline 4 & Other forms of heart disease (130-152) & 274 & 2,9 & 4 & Cerebrovascular diseases (160-169) & 762 & 4,9 & 4 & Diabetes mellitus (E10-E14) & 520 & 4,4 \\
\hline 5 & Influenza and pneumonia (J09-J18) & 247 & 2,6 & 5 & Influenza and pneumonia (J09-J18) & 743 & 4,8 & 5 & Malignant neoplasm of digestive organs (C15-C26) & 508 & 4,3 \\
\hline 6 & Other viral diseases (B25-B34) & 233 & 2,5 & 6 & Intestinal infectious diseases (A00-A09) & 676 & 4,3 & 6 & Chronic lower respiratory diseases (J40-J47) & 490 & 4,2 \\
\hline 7 & Other acute lower respiratory infections (J20-J22) & 201 & 2,1 & 7 & Other viral diseases (B25-B34) & 646 & 4,2 & 7 & Influenza and pneumonia (J09-J18) & 463 & 3,9 \\
\hline 8 & Cerebrovascular diseases (160-169) & 184 & 1,9 & 7 & $\begin{array}{l}\text { Human immunodeficiency virus [HIV] disease } \\
\text { (B20-B24) }\end{array}$ & 606 & 3,9 & 8 & Hypertensive diseases (110-115) & 317 & 2,7 \\
\hline 9 & $\begin{array}{l}\text { Certain disorders involving the immune mechanism } \\
\text { (D80-D89) }\end{array}$ & 173 & 1,8 & 9 & Diabetes mellitus (E10-E14) & 474 & 3,0 & 9 & $\begin{array}{l}\text { Human immunodeficiency virus [HIV] disease } \\
\text { (B20-B24) }\end{array}$ & 307 & 2,6 \\
\hline 10 & $\begin{array}{l}\text { Human immunodeficiency virus [HIV] disease } \\
\text { (B20-B24) }\end{array}$ & 145 & 1,5 & 10 & Hypertensive diseases (110-115) & 432 & 2,8 & 10 & Intestinal infectious diseases (A00-A09) & 299 & 2,5 \\
\hline & Other natural causes & 5630 & 59,4 & & Other natural causes & 6400 & 41,1 & & Other natural causes & 4367 & 37,2 \\
\hline & Non-natural causes & 738 & 7,8 & & Non-natural causes & 1222 & 7,9 & & Non-natural causes & 1292 & 11,0 \\
\hline & All causes & 9474 & 100,0 & & All causes & 15561 & 100,0 & & All causes & 11755 & 100,0 \\
\hline & Cacadu & No. & $\%$ & & Chris Hani & No. & $\%$ & & Joe Gqabi & No. & $\%$ \\
\hline 1 & Tuberculosis (A15-A19) & 651 & 13,4 & 1 & Tuberculosis (A15-A19) & 1369 & 14,5 & 1 & Tuberculosis (A15-A19) & 826 & 14,9 \\
\hline 2 & Other forms of heart disease (130-152) & 249 & 5,1 & 2 & Influenza and pneumonia (J09-J18) & 779 & 8,3 & 2 & Influenza and pneumonia (J09-J18) & 374 & 6,7 \\
\hline 3 & $\begin{array}{l}\text { Human immunodeficiency virus [HIV] disease } \\
\text { (B20-B24) }\end{array}$ & 242 & 5,0 & 3 & Other forms of heart disease (130-152) & 508 & 5,4 & 3 & Other forms of heart disease (130-152) & 336 & 6,1 \\
\hline 4 & Cerebrovascular diseases (160-169) & 234 & 4,8 & 4 & Intestinal infectious diseases (A00-A09) & 507 & 5,4 & 4 & Other diseases of the respiratory system (J95-J99) & 300 & 5,4 \\
\hline 5 & Chronic lower respiratory diseases (J40-J47) & 206 & 4,2 & 5 & Chronic lower respiratory diseases (J40-J47) & 504 & 5,4 & 5 & Intestinal infectious diseases (A00-A09) & 277 & 5,0 \\
\hline 6 & Influenza and pneumonia (J09-J18) & 202 & 4,1 & 6 & Cerebrovascular diseases (160-169) & 411 & 4,4 & 6 & $\begin{array}{l}\text { Certain disorders involving the immune } \\
\text { mechanism (D80-D89) }\end{array}$ & 220 & 4,0 \\
\hline 7 & Ischaemic heart diseases (120-125) & 180 & 3,7 & 7 & Other viral diseases (B25-B34) & 333 & 3,5 & 7 & $\begin{array}{l}\text { Human immunodeficiency virus [HIV] disease } \\
\text { (B20-B24) }\end{array}$ & 206 & 3,7 \\
\hline 8 & Hypertensive diseases (110-115) & 170 & 3,5 & 8 & Diabetes mellitus (E10-E14) & 302 & 3,2 & 8 & Cerebrovascular diseases (160-169) & 193 & 3,5 \\
\hline 9 & Diabetes mellitus (E10-E14) & 152 & 3,1 & 9 & $\begin{array}{l}\text { Certain disorders involving the immune } \\
\text { mechanism (D80-D89) }\end{array}$ & 289 & 3,1 & 9 & Chronic lower respiratory diseases (J40-J47) & 162 & 2,9 \\
\hline 10 & $\begin{array}{l}\text { Certain disorders involving the immune mechanism } \\
\text { (D80-D89) }\end{array}$ & 125 & 2,6 & 10 & Hypertensive diseases (110-115) & 253 & 2,7 & 10 & Other viral diseases (B25-B34) & 132 & 2,4 \\
\hline & Other natural causes & 1985 & 40,7 & & Other natural causes & 3389 & 36,0 & & Other natural causes & 2163 & 39,0 \\
\hline & Non-natural causes & 477 & 9,8 & & Non-natural causes & 766 & 8,1 & & Non-natural causes & 353 & 6,4 \\
\hline & All causes & 4873 & 100,0 & & All causes & 9410 & 100,0 & & All causes & 5542 & 100,0 \\
\hline
\end{tabular}


Appendix N.1: The ten leading underlying natural causes of death by district municipality of death occurrence, Eastern Cape, 2009 (concluded)

\begin{tabular}{|c|c|c|c|c|c|c|c|}
\hline \multicolumn{2}{|r|}{ Nelson Mandela Bay Metro } & No. & $\%$ & \multicolumn{2}{|r|}{ O.R. Tambo } & \multirow{2}{*}{$\begin{aligned} \text { No. } \\
1465\end{aligned}$} & \multirow{2}{*}{$\begin{array}{r}\% \\
12,8\end{array}$} \\
\hline 1 & Tuberculosis (A15-A19) & 2221 & 15,8 & 1 & Tuberculosis (A15-A19) & & \\
\hline 2 & Diabetes mellitus (E10-E14) & 812 & 5,8 & 2 & Intestinal infectious diseases (A00-A09) & 427 & 3,7 \\
\hline 3 & Cerebrovascular diseases (160-169) & 658 & 4,7 & 3 & Other viral diseases (B25-B34) & 417 & 3,6 \\
\hline 4 & Hypertensive diseases (110-115) & 643 & 4,6 & 4 & Influenza and pneumonia (J09-J18) & 415 & 3,6 \\
\hline 5 & Chronic lower respiratory diseases (J40-J47) & 612 & 4,4 & 5 & $\begin{array}{l}\text { Human immunodeficiency virus [HIV] disease } \\
\text { (B20-B24) }\end{array}$ & 405 & 3,5 \\
\hline 6 & Other forms of heart disease (130-152) & 491 & 3,5 & 6 & Other forms of heart disease (130-152) & 316 & 2,8 \\
\hline 7 & Ischaemic heart diseases (I20-125) & 489 & 3,5 & 7 & Cerebrovascular diseases (160-169) & 291 & 2,5 \\
\hline 8 & Influenza and pneumonia (J09-J18) & 466 & 3,3 & 7 & Chronic lower respiratory diseases (J40-J47) & 282 & 2,5 \\
\hline 9 & $\begin{array}{l}\text { Certain disorders involving the immune mechanism } \\
\text { (D80-D89) }\end{array}$ & 418 & 3,0 & 9 & Diabetes mellitus (E10-E14) & 278 & 2,4 \\
\hline \multirow[t]{4}{*}{10} & $\begin{array}{l}\text { Human immunodeficiency virus [HIV] disease } \\
\text { (B20-B24) }\end{array}$ & 355 & 2,5 & 10 & $\begin{array}{l}\text { Certain disorders involving the immune } \\
\text { mechanism (D80-D89) }\end{array}$ & 235 & 2,1 \\
\hline & Other natural causes & 5582 & 39,7 & & Other natural causes & 5860 & 51,2 \\
\hline & Non-natural causes & 1305 & 9,3 & & Non-natural causes & 1061 & 9,3 \\
\hline & All causes & 14052 & 100,0 & & All causes & 11452 & 100,0 \\
\hline
\end{tabular}




\section{Appendix N.2: The ten leading underlying natural causes of death by district municipality of death occurrence, Northern Cape, 2009}

\begin{tabular}{|c|c|c|c|c|c|c|c|c|c|c|c|}
\hline & Frances Baard & No. & $\%$ & & John Taolo Gaetsewe & No. & $\%$ & & Namakwa & No. & $\%$ \\
\hline 1 & Tuberculosis (A15-A19) & 481 & 10,7 & 1 & Intestinal infectious diseases (A00-A09) & 175 & 6,4 & 1 & Other forms of heart disease (130-152) & 86 & 7,8 \\
\hline 2 & $\begin{array}{l}\text { Human immunodeficiency virus [HIV] disease } \\
\text { (B20-B24) }\end{array}$ & 313 & 7,0 & 2 & Tuberculosis (A15-A19) & 156 & 5,7 & 2 & Chronic lower respiratory diseases (J40-J47) & 82 & 7,5 \\
\hline 3 & Influenza and pneumonia (J09-J18) & 257 & 5,7 & 3 & Influenza and pneumonia (J09-J18) & 150 & 5,5 & 3 & Tuberculosis (A15-A19) & 74 & 6,7 \\
\hline 4 & Cerebrovascular diseases (160-169) & 195 & 4,3 & 4 & Other diseases of the respiratory system (J95-J99) & 121 & 4,4 & 4 & Diabetes mellitus (E10-E14) & 62 & 5,6 \\
\hline 5 & $\begin{array}{l}\text { Certain disorders involving the immune mechanism } \\
\text { (D80-D89) }\end{array}$ & 170 & 3,8 & 5 & Other acute lower respiratory infections (J20-J22) & 118 & 4,3 & 5 & Ischaemic heart diseases (120-125) & 52 & 4,7 \\
\hline 6 & Other forms of heart disease (130-152) & 160 & 3,6 & 6 & $\begin{array}{l}\text { Human immunodeficiency virus [HIV] disease } \\
\text { (B20-B24) }\end{array}$ & 82 & 3,0 & 6 & Cerebrovascular diseases (160-169) & 51 & 4,6 \\
\hline 7 & Intestinal infectious diseases (A00-A09) & 154 & 3,4 & 7 & Other forms of heart disease (130-152) & 69 & 2,5 & 7 & $\begin{array}{l}\text { Malignant neoplasm of respiratory and } \\
\text { intrathoracic organs (C30-39) }\end{array}$ & 43 & 3,9 \\
\hline 8 & Hypertensive diseases (110-115) & 135 & 3,0 & 7 & Cerebrovascular diseases (160-169) & 67 & 2,4 & 8 & $\begin{array}{l}\text { Other diseases of the respiratory system (J95- } \\
\text { J99) }\end{array}$ & 36 & 3,3 \\
\hline 9 & Chronic lower respiratory diseases (J40-J47) & 118 & 2,6 & 9 & Hypertensive diseases (110-115) & 61 & 2,2 & 9 & Hypertensive diseases (110-115) & 32 & 2,9 \\
\hline 10 & Diabetes mellitus (E10-E14) & 112 & 2,5 & 10 & $\begin{array}{l}\text { Respiratory and cardiovascular disorders specific } \\
\text { to the perinatal period (P20-P29) }\end{array}$ & 40 & 1,5 & 10 & $\begin{array}{l}\text { Malignant neoplasm of digestive organs (C15- } \\
\mathrm{C} 26 \text { ) }\end{array}$ & 25 & 2,3 \\
\hline & Other natural causes & 2031 & 45,3 & & Other natural causes & 1543 & 56,2 & & Other natural causes & 427 & 38,9 \\
\hline & Non-natural causes & 361 & 8,0 & & Non-natural causes & 162 & 5,9 & & Non-natural causes & 129 & 11,7 \\
\hline & All causes & 4487 & 100,0 & & All causes & 2744 & 100,0 & & All causes & 1099 & 100,0 \\
\hline & Pixley ka Seme & No. & $\%$ & & Siyanda & No. & $\%$ & & & & \\
\hline 1 & Tuberculosis (A15-A19) & 307 & 11,6 & 1 & Tuberculosis (A15-A19) & 447 & 10,9 & & & & \\
\hline 2 & Influenza and pneumonia (J09-J18) & 183 & 6,9 & 2 & $\begin{array}{l}\text { Human immunodeficiency virus [HIV] disease } \\
\text { (B20-B24) }\end{array}$ & 393 & 9,6 & & & & \\
\hline 3 & Cerebrovascular diseases (160-169) & 146 & 5,5 & 3 & Influenza and pneumonia (J09-J18) & 234 & 5,7 & & & & \\
\hline 4 & Chronic lower respiratory diseases (J40-J47) & 142 & 5,4 & 4 & Chronic lower respiratory diseases (J40-J47) & 198 & 4,8 & & & & \\
\hline 5 & Other forms of heart disease (130-152) & 120 & 4,5 & 5 & Cerebrovascular diseases (160-169) & 173 & 4,2 & & & & \\
\hline 6 & Intestinal infectious diseases (A00-A09) & 90 & 3,4 & 6 & Diabetes mellitus (E10-E14) & 151 & 3,7 & & & & \\
\hline 7 & Diabetes mellitus (E10-E14) & 87 & 3,3 & 7 & Other forms of heart disease (130-152) & 147 & 3,6 & & & & \\
\hline 8 & $\begin{array}{l}\text { Human immunodeficiency virus [HIV] disease } \\
\text { (B20-B24) }\end{array}$ & 86 & 3,3 & 8 & Hypertensive diseases (110-115) & 141 & 3,4 & & & & \\
\hline 9 & Hypertensive diseases (110-115) & 78 & 3,0 & 9 & Intestinal infectious diseases (A00-A09) & 138 & 3,4 & & & & \\
\hline 10 & Other viral diseases (B25-B34) & 76 & 2,9 & 10 & $\begin{array}{l}\text { Certain disorders involving the immune } \\
\text { mechanism (D80-D89) }\end{array}$ & 120 & 2,9 & & & & \\
\hline & Other natural causes & 1103 & 41,8 & & Other natural causes & 1569 & 38,2 & & & & \\
\hline & Non-natural causes & 223 & 8,4 & & Non-natural causes & 400 & 9,7 & & & & \\
\hline & All causes & 2641 & 100,0 & & All causes & 4111 & 100,0 & & & & \\
\hline
\end{tabular}




\section{Appendix N.3: The ten leading underlying natural causes of death by district municipality of death occurrence, Free State, 2009}

\begin{tabular}{|c|c|c|c|c|c|c|c|c|c|c|c|}
\hline & Fezile Dabi & \multirow{2}{*}{$\begin{array}{l}\text { No. } \\
902\end{array}$} & \multirow{2}{*}{$\begin{array}{r}\% \\
12,6\end{array}$} & & \multirow{2}{*}{$\begin{array}{r}\text { No. } \\
1856\end{array}$} & \multirow{2}{*}{$\begin{array}{r}\% \\
16,3 \\
\end{array}$} & & \multirow{2}{*}{$\begin{array}{r}\text { No. } \\
1600\end{array}$} & \multirow{2}{*}{$\begin{array}{r}\% \\
12,0\end{array}$} \\
\hline 1 & Influenza and pneumonia (J09-J18) & & & \multicolumn{2}{|c|}{$\begin{array}{cc} & \text { Lejweleputswa } \\
1 & \text { Influenza and pneumonia (J09-J18) }\end{array}$} & & & \multicolumn{2}{|c|}{$\begin{array}{rr} & \text { Mangaung Metro } \\
1 & \text { Tuberculosis (A15-A19) }\end{array}$} & & \\
\hline 2 & Tuberculosis (A15-A19) & 770 & 10,8 & 2 & Tuberculosis (A15-A19) & 1269 & 11,2 & 2 & Influenza and pneumonia (J09-J18) & 1148 & 8,6 \\
\hline 3 & Intestinal infectious diseases (A00-A09) & 564 & 7,9 & 3 & Intestinal infectious diseases (A00-A09) & 816 & 7,2 & 3 & Intestinal infectious diseases (A00-A09) & 525 & 3,9 \\
\hline 4 & Other forms of heart disease (130-152) & 420 & 5,9 & 4 & Other forms of heart disease (130-152) & 548 & 4,8 & 4 & Other forms of heart disease (130-152) & 455 & 3,4 \\
\hline 5 & $\begin{array}{l}\text { Certain disorders involving the immune mechanism } \\
\text { (D80-D89) }\end{array}$ & 351 & 4,9 & 5 & $\begin{array}{l}\text { Certain disorders involving the immune } \\
\text { mechanism (D80-D89) }\end{array}$ & 410 & 3,6 & 5 & Cerebrovascular diseases (160-169) & 433 & 3,2 \\
\hline 6 & Diabetes mellitus (E10-E14) & 310 & 4,3 & 6 & Cerebrovascular diseases (160-169) & 396 & 3,5 & 6 & $\begin{array}{l}\text { Certain disorders involving the immune } \\
\text { mechanism (D80-D89) }\end{array}$ & 377 & 2,8 \\
\hline 7 & Cerebrovascular diseases (160-169) & 300 & 4,2 & 7 & $\begin{array}{l}\text { Human immunodeficiency virus [HIV] disease } \\
\text { (B20-B24) }\end{array}$ & 299 & 2,6 & 7 & Hypertensive diseases (110-115) & 286 & 2,1 \\
\hline 8 & Hypertensive diseases (110-115) & 275 & 3,8 & 7 & Hypertensive diseases (110-115) & 261 & 2,3 & 8 & Diabetes mellitus (E10-E14) & 279 & 2,1 \\
\hline 9 & Chronic lower respiratory diseases (J40-J47) & 171 & 2,4 & 9 & Diabetes mellitus (E10-E14) & 222 & 2,0 & 9 & Malignant neoplasm of digestive organs (C15-C26) & 220 & 1,7 \\
\hline 10 & Ischaemic heart diseases (120-125) & 143 & 2,0 & 10 & Chronic lower respiratory diseases (J40-J47) & 207 & 1,8 & 10 & Ischaemic heart diseases (120-125) & 189 & 1,4 \\
\hline & Other natural causes & 2377 & 33,2 & & Other natural causes & 4359 & 38,3 & & Other natural causes & 6919 & 51,9 \\
\hline & Non-natural causes & 576 & 8,0 & & Non-natural causes & 733 & 6,4 & & Non-natural causes & 900 & 6,8 \\
\hline & All causes & 7159 & 100,0 & & All causes & 11376 & 100,0 & & All causes & 13331 & 100,0 \\
\hline & Thabo Mofutsanyane & No. & $\%$ & & Xhariep & No. & $\%$ & & & & \\
\hline 1 & Influenza and pneumonia (J09-J18) & 1665 & 12,6 & 1 & Influenza and pneumonia (J09-J18) & 301 & 13,6 & & & & \\
\hline 2 & Tuberculosis (A15-A19) & 1307 & 9,9 & 2 & Tuberculosis (A15-A19) & 233 & 10,5 & & & & \\
\hline 3 & Intestinal infectious diseases (A00-A09) & 1128 & 8,6 & 3 & Intestinal infectious diseases (A00-A09) & 157 & 7,1 & & & & \\
\hline 4 & Other forms of heart disease (130-152) & 897 & 6,8 & 4 & $\begin{array}{l}\text { Certain disorders involving the immune } \\
\text { mechanism (D80-D89) }\end{array}$ & 125 & 5,6 & & & & \\
\hline 5 & $\begin{array}{l}\text { Certain disorders involving the immune mechanism } \\
\text { (D80-D89) }\end{array}$ & 831 & 6,3 & 5 & Cerebrovascular diseases (160-169) & 99 & 4,5 & & & & \\
\hline 6 & Cerebrovascular diseases (160-169) & 559 & 4,2 & 6 & Other forms of heart disease (130-152) & 91 & 4,1 & & & & \\
\hline 7 & Diabetes mellitus (E10-E14) & 410 & 3,1 & 7 & Chronic lower respiratory diseases (J40-J47) & 66 & 3,0 & & & & \\
\hline 8 & Hypertensive diseases (110-115) & 386 & 2,9 & 8 & Hypertensive diseases (110-115) & 58 & 2,6 & & & & \\
\hline 9 & Other diseases of the respiratory system (J95-J99) & 324 & 2,5 & 9 & Diabetes mellitus (E10-E14) & 41 & 1,9 & & & & \\
\hline 10 & Chronic lower respiratory diseases (J40-J47) & 313 & 2,4 & 10 & Other viral diseases (B25-B34) & 39 & 1,8 & & & & \\
\hline & Other natural causes & 4612 & 35,0 & & Other natural causes & 834 & 37,6 & & & & \\
\hline & Non-natural causes & 747 & 5,7 & & Non-natural causes & 172 & 7,8 & & & & \\
\hline & All causes & 13179 & 100,0 & & All causes & 2216 & 100,0 & & & & \\
\hline
\end{tabular}




\section{Appendix N.4: The ten leading underlying natural causes of death by district municipality of death occurrence, KwaZulu-Natal, 2009}

\begin{tabular}{|c|c|c|c|c|c|c|c|c|c|c|c|}
\hline \multicolumn{2}{|r|}{ Amajuba } & No. & $\%$ & \multicolumn{2}{|r|}{ eThekweni Metro } & \multirow{2}{*}{ No. } & \multirow{2}{*}{$\begin{array}{r}\% \\
14,9\end{array}$} & \multicolumn{2}{|r|}{ iLembe } & \multirow{2}{*}{$\frac{\text { No. }}{1234}$} & \multirow{2}{*}{$\begin{array}{r}\% \\
18,4\end{array}$} \\
\hline 1 & Tuberculosis (A15-A19) & 1036 & 15,7 & 1 & Tuberculosis (A15-A19) & & & 1 & Tuberculosis (A15-A19) & & \\
\hline 2 & Other acute lower respiratory infections (J20-J22) & 597 & 9,0 & 2 & Influenza and pneumonia (J09-J18) & 1997 & 5,1 & 2 & Intestinal infectious diseases (A00-A09) & 571 & 8,5 \\
\hline 3 & Influenza and pneumonia (J09-J18) & 516 & 7,8 & 3 & Other forms of heart disease (130-152) & 1950 & 5,0 & 3 & Other viral diseases (B25-B34) & 420 & 6,3 \\
\hline 4 & Intestinal infectious diseases (A00-A09) & 438 & 6,6 & 4 & Intestinal infectious diseases (A00-A09) & 1927 & 4,9 & 4 & Cerebrovascular diseases (160-169) & 417 & 6,2 \\
\hline 5 & Cerebrovascular diseases (160-169) & 420 & 6,4 & 5 & Diabetes mellitus (E10-E14) & 1771 & 4,5 & 5 & Diabetes mellitus (E10-E14) & 276 & 4,1 \\
\hline 6 & Other forms of heart disease (130-152) & 289 & 4,4 & 6 & Cerebrovascular diseases (160-169) & 1568 & 4,0 & 6 & Influenza and pneumonia (J09-J18) & 221 & 3,3 \\
\hline 7 & Diabetes mellitus (E10-E14) & 233 & 3,5 & 7 & Ischaemic heart diseases (I20-I25) & 1324 & 3,4 & 7 & Other forms of heart disease (130-152) & 199 & 3,0 \\
\hline 8 & Other diseases of the respiratory system (J95-J99) & 218 & 3,3 & 7 & $\begin{array}{l}\text { Human immunodeficiency virus [HIV] disease } \\
\text { (B20-B24) }\end{array}$ & 1112 & 2,8 & 8 & $\begin{array}{l}\text { Human immunodeficiency virus [HIV] disease } \\
\text { (B20-B24) }\end{array}$ & 144 & 2,1 \\
\hline 9 & Hypertensive diseases (110-I15) & 157 & 2,4 & 9 & Other viral diseases (B25-B34) & 858 & 2,2 & 9 & Hypertensive diseases (110-115) & 141 & 2,1 \\
\hline 10 & $\begin{array}{l}\text { Certain disorders involving the immune mechanism } \\
\text { (D80-D89) }\end{array}$ & 150 & 2,3 & 10 & Hypertensive diseases (110-115) & 710 & 1,8 & 10 & Chronic lower respiratory diseases (J40-J47) & 111 & 1,7 \\
\hline & Other natural causes & 2142 & 32,4 & & Other natural causes & 16563 & 42,1 & & Other natural causes & 2354 & 35,0 \\
\hline & Non-natural causes & 408 & 6,2 & & Non-natural causes & 3738 & 9,5 & & Non-natural causes & 632 & 9,4 \\
\hline & All causes & 6604 & 100,0 & & All causes & 39365 & 100,0 & & All causes & 6720 & 100,0 \\
\hline & Sisonke & No. & $\%$ & & Ugu & No. & $\%$ & & UMgungundlovu & No. & $\%$ \\
\hline 1 & Tuberculosis (A15-A19) & 856 & 18,6 & 1 & Tuberculosis (A15-A19) & 2051 & 17,1 & 1 & Tuberculosis (A15-A19) & 2202 & 15,9 \\
\hline 2 & Intestinal infectious diseases (A00-A09) & 302 & 6,6 & 2 & Influenza and pneumonia (J09-J18) & 823 & 6,9 & 2 & Intestinal infectious diseases (A00-A09) & 817 & 5,9 \\
\hline 3 & Influenza and pneumonia (J09-J18) & 268 & 5,8 & 3 & Intestinal infectious diseases (A00-A09) & 812 & 6,8 & 3 & Cerebrovascular diseases (160-169) & 718 & 5,2 \\
\hline 4 & Cerebrovascular diseases (160-169) & 216 & 4,7 & 4 & Cerebrovascular diseases (160-169) & 780 & 6,5 & 4 & Influenza and pneumonia (J09-J18) & 710 & 5,1 \\
\hline 5 & Other viral diseases (B25-B34) & 215 & 4,7 & 5 & $\begin{array}{l}\text { Human immunodeficiency virus [HIV] disease } \\
\text { (B20-B24) }\end{array}$ & 570 & 4,8 & 5 & Diabetes mellitus (E10-E14) & 593 & 4,3 \\
\hline 6 & Chronic lower respiratory diseases (J40-J47) & 210 & 4,6 & 6 & Diabetes mellitus (E10-E14) & 507 & 4,2 & 6 & Other forms of heart disease (130-152) & 538 & 3,9 \\
\hline 7 & Diabetes mellitus (E10-E14) & 155 & 3,4 & 7 & Other forms of heart disease (130-152) & 416 & 3,5 & 7 & $\begin{array}{l}\text { Human immunodeficiency virus [HIV] disease } \\
\text { (B20-B24) }\end{array}$ & 507 & 3,7 \\
\hline 8 & $\begin{array}{l}\text { Human immunodeficiency virus [HIV] disease } \\
\text { (B20-B24) }\end{array}$ & 136 & 3,0 & 8 & Chronic lower respiratory diseases (J40-J47) & 382 & 3,2 & 8 & Ischaemic heart diseases (120-125) & 393 & 2,8 \\
\hline 9 & Other forms of heart disease (I30-152) & 127 & 2,8 & 9 & Hypertensive diseases (110-115) & 362 & 3,0 & 9 & Other acute lower respiratory infections (J20-J22) & 368 & 2,7 \\
\hline 10 & $\begin{array}{l}\text { Certain disorders involving the immune mechanism } \\
\text { (D80-D89) }\end{array}$ & 86 & 1,9 & 10 & Other viral diseases (B25-B34) & 292 & 2,4 & 10 & Hypertensive diseases (110-115) & 360 & 2,6 \\
\hline & Other natural causes & 1707 & 37,1 & & Other natural causes & 4064 & 33,9 & & Other natural causes & 5387 & 39,0 \\
\hline & Non-natural causes & 325 & 7,1 & & Non-natural causes & 930 & 7,8 & & Non-natural causes & 1226 & 8,9 \\
\hline & All causes & 4603 & 100,0 & & All causes & 11989 & 100,0 & & All causes & 13819 & 100,0 \\
\hline
\end{tabular}


Appendix N.4: The ten leading underlying natural causes of death by district municipality of death occurrence, KwaZulu-Natal, 2009 (concluded)

\begin{tabular}{|c|c|c|c|c|c|c|c|c|c|c|c|}
\hline \multicolumn{2}{|r|}{ Umkhanyakude } & No. & $\%$ & \multicolumn{2}{|r|}{ Umzinyathi } & \multirow{2}{*}{$\begin{aligned} \text { No. } \\
1042\end{aligned}$} & \multirow{2}{*}{$\begin{array}{r}\% \\
16,8\end{array}$} & \multicolumn{2}{|r|}{ Uthukela } & \multirow{2}{*}{$\begin{aligned} \text { No. } \\
1403\end{aligned}$} & \multirow{2}{*}{$\begin{array}{r}\% \\
15,9\end{array}$} \\
\hline 1 & Tuberculosis (A15-A19) & 923 & 14,5 & 1 & Tuberculosis (A15-A19) & & & 1 & Tuberculosis (A15-A19) & & \\
\hline 2 & $\begin{array}{l}\text { Human immunodeficiency virus [HIV] disease } \\
\text { (B20-B24) }\end{array}$ & 791 & 12,4 & 2 & Cerebrovascular diseases (160-169) & 393 & 6,3 & 2 & Influenza and pneumonia (J09-J18) & 816 & 9,3 \\
\hline 3 & Intestinal infectious diseases (A00-A09) & 310 & 4,9 & 3 & Intestinal infectious diseases (A00-A09) & 386 & 6,2 & 3 & Intestinal infectious diseases (A00-A09) & 778 & 8,8 \\
\hline 4 & Cerebrovascular diseases (160-169) & 251 & 3,9 & 4 & Influenza and pneumonia (J09-J18) & 321 & 5,2 & 4 & Cerebrovascular diseases (160-169) & 597 & 6,8 \\
\hline 5 & Other viral diseases (B25-B34) & 226 & 3,6 & 5 & Other viral diseases (B25-B34) & 286 & 4,6 & 5 & Other forms of heart disease (130-152) & 437 & 5,0 \\
\hline 6 & Influenza and pneumonia (J09-J18) & 205 & 3,2 & 6 & Other forms of heart disease (130-152) & 212 & 3,4 & 6 & $\begin{array}{l}\text { Certain disorders involving the immune } \\
\text { mechanism (D80-D89) }\end{array}$ & 329 & 3,7 \\
\hline 7 & Other forms of heart disease (130-152) & 181 & 2,8 & 7 & Diabetes mellitus (E10-E14) & 179 & 2,9 & 7 & Diabetes mellitus (E10-E14) & 314 & 3,6 \\
\hline 8 & Hypertensive diseases (110-115) & 136 & 2,1 & 7 & $\begin{array}{l}\text { Human immunodeficiency virus [HIV] disease } \\
\text { (B20-B24) }\end{array}$ & 176 & 2,8 & 8 & $\begin{array}{l}\text { Human immunodeficiency virus [HIV] disease } \\
\text { (B20-B24) }\end{array}$ & 225 & 2,6 \\
\hline 9 & Diabetes mellitus (E10-E14) & 113 & 1,8 & 9 & Other acute lower respiratory infections (J20-J22) & 115 & 1,9 & 9 & Other viral diseases (B25-B34) & 213 & 2,4 \\
\hline \multirow[t]{5}{*}{10} & Other acute lower respiratory infections (J20-J22) & 82 & 1,3 & 10 & Chronic lower respiratory diseases (J40-J47) & 95 & 1,5 & 10 & Hypertensive diseases (110-I15) & 212 & 2,4 \\
\hline & Other natural causes & 2676 & 42,1 & & Other natural causes & 2495 & 40,2 & & Other natural causes & 2674 & 30,4 \\
\hline & Non-natural causes & 462 & 7,3 & & Non-natural causes & 508 & 8,2 & & Non-natural causes & 803 & 9,1 \\
\hline & All causes & 6356 & 100,0 & & All causes & 6208 & 100,0 & & All causes & 8801 & 100,0 \\
\hline & Uthungulu & No. & $\%$ & \multicolumn{2}{|r|}{ Zululand } & No. & $\%$ & & & & \\
\hline 1 & Tuberculosis (A15-A19) & 2019 & 17,4 & 1 & Tuberculosis (A15-A19) & 1648 & 18,4 & & & & \\
\hline 2 & $\begin{array}{l}\text { Human immunodeficiency virus [HIV] disease } \\
\text { (B20-B24) }\end{array}$ & 734 & 6,3 & 2 & Intestinal infectious diseases (A00-A09) & 757 & 8,5 & & & & \\
\hline 3 & Influenza and pneumonia (J09-J18) & 638 & 5,5 & 3 & Influenza and pneumonia (J09-J18) & 520 & 5,8 & & & & \\
\hline 4 & Intestinal infectious diseases (A00-A09) & 614 & 5,3 & 4 & Other forms of heart disease (130-152) & 395 & 4,4 & & & & \\
\hline 5 & Other forms of heart disease (130-152) & 556 & 4,8 & 5 & Other viral diseases (B25-B34) & 378 & 4,2 & & & & \\
\hline 6 & Other viral diseases (B25-B34) & 464 & 4,0 & 6 & Cerebrovascular diseases (160-169) & 348 & 3,9 & & & & \\
\hline 7 & Diabetes mellitus (E10-E14) & 456 & 3,9 & 7 & Other acute lower respiratory infections (J20-J22) & 323 & 3,6 & & & & \\
\hline 8 & Cerebrovascular diseases (160-169) & 455 & 3,9 & 8 & $\begin{array}{l}\text { Human immunodeficiency virus [HIV] disease } \\
\text { (B20-B24) }\end{array}$ & 273 & 3,1 & & & & \\
\hline 9 & $\begin{array}{l}\text { Certain disorders involving the immune mechanism } \\
\text { (D80-D89) }\end{array}$ & 256 & 2,2 & 9 & Diabetes mellitus (E10-E14) & 249 & 2,8 & & & & \\
\hline 9 & Hypertensive diseases (110-I15) & 256 & 2,2 & 10 & $\begin{array}{l}\text { Inflammatory diseases of the central nervous } \\
\text { system (G00-G09) }\end{array}$ & 210 & 2,3 & & & & \\
\hline & Other natural causes & 4127 & 35,7 & & Other natural causes & 3237 & 36,2 & & & & \\
\hline & Non-natural causes & 1000 & 8,6 & & Non-natural causes & 600 & 6,7 & & & & \\
\hline & All causes & 11575 & 100,0 & & All causes & 8938 & 100,0 & & & & \\
\hline
\end{tabular}




\section{Appendix N.5: The ten leading underlying natural causes of death by district municipality of death occurrence, North West, 2009}

\begin{tabular}{|c|c|c|c|c|c|c|c|c|c|c|c|}
\hline \multicolumn{2}{|r|}{ Bojanala } & No. & $\%$ & \multicolumn{2}{|r|}{ Dr Kenneth Kaunda } & \multirow{2}{*}{$\begin{aligned} \text { No. } \\
1520\end{aligned}$} & \multirow{2}{*}{\begin{tabular}{r|r|}
$\%$ \\
16,4
\end{tabular}} & \multicolumn{2}{|r|}{ Dr Ruth Segomotsi Mompati } & \multirow{2}{*}{ No. } & \multirow{2}{*}{$\begin{aligned} \% \\
12,4\end{aligned}$} \\
\hline 1 & Tuberculosis (A15-A19) & 1257 & 9,1 & 1 & Tuberculosis (A15-A19) & & & 1 & Tuberculosis (A15-A19) & & \\
\hline 2 & Influenza and pneumonia (J09-J18) & 1118 & 8,1 & 2 & Influenza and pneumonia (J09-J18) & 661 & 7,1 & 2 & Influenza and pneumonia (J09-J18) & 488 & 7,5 \\
\hline 3 & Other forms of heart disease (130-152) & 966 & 7,0 & 3 & Intestinal infectious diseases (A00-A09) & 431 & 4,7 & 3 & Intestinal infectious diseases (A00-A09) & 480 & 7,4 \\
\hline 4 & Intestinal infectious diseases (A00-A09) & 811 & 5,9 & 4 & Other forms of heart disease (130-152) & 344 & 3,7 & 4 & Other forms of heart disease (130-152) & 313 & 4,8 \\
\hline 5 & $\begin{array}{l}\text { Certain disorders involving the immune mechanism } \\
\text { (D80-D89) }\end{array}$ & 604 & 4,4 & 5 & Cerebrovascular diseases (160-169) & 324 & 3,5 & 5 & Hypertensive diseases (110-115) & 295 & 4,5 \\
\hline 6 & Cerebrovascular diseases (160-169) & 558 & 4,0 & 6 & $\begin{array}{l}\text { Human immunodeficiency virus [HIV] disease } \\
\text { (B20-B24) }\end{array}$ & 293 & 3,2 & 6 & Other acute lower respiratory infections (J20-J22) & 276 & 4,2 \\
\hline 7 & Hypertensive diseases (110-I15) & 524 & 3,8 & 7 & Chronic lower respiratory diseases (J40-J47) & 258 & 2,8 & 7 & Cerebrovascular diseases (160-169) & 251 & 3,9 \\
\hline 8 & Diabetes mellitus (E10-E14) & 406 & 2,9 & 7 & Hypertensive diseases (110-115) & 253 & 2,7 & 8 & Other viral diseases (B25-B34) & 244 & 3,8 \\
\hline 9 & Other viral diseases (B25-B34) & 318 & 2,3 & 9 & $\begin{array}{l}\text { Certain disorders involving the immune } \\
\text { mechanism (D80-D89) }\end{array}$ & 241 & 2,6 & 9 & $\begin{array}{l}\text { Human immunodeficiency virus [HIV] disease } \\
\text { (B20-B24) }\end{array}$ & 219 & 3,4 \\
\hline \multirow[t]{5}{*}{10} & $\begin{array}{l}\text { Human immunodeficiency virus [HIV] disease } \\
\text { (B20-B24) }\end{array}$ & 283 & 2,0 & 10 & Ischaemic heart diseases (120-I25) & 200 & 2,2 & 10 & $\begin{array}{l}\text { Certain disorders involving the immune } \\
\text { mechanism (D80-D89) }\end{array}$ & 205 & 3,2 \\
\hline & Other natural causes & 5841 & 42,3 & & Other natural causes & 3971 & 42,9 & & Other natural causes & 2570 & 39,5 \\
\hline & Non-natural causes & 1134 & 8,2 & & Non-natural causes & 766 & 8,3 & & Non-natural causes & 353 & 5,4 \\
\hline & All causes & 13820 & 100,0 & & All causes & 9262 & 100,0 & & All causes & 6502 & 100,0 \\
\hline & Ngaka Modiri Molema & No. & $\%$ & & & & & & & & \\
\hline 1 & Influenza and pneumonia (J09-J18) & 1627 & 15,1 & & & & & & & & \\
\hline 2 & Tuberculosis (A15-A19) & 1397 & 13,0 & & & & & & & & \\
\hline 3 & Other forms of heart disease (130-152) & 660 & 6,1 & & & & & & & & \\
\hline 4 & Intestinal infectious diseases (A00-A09) & 608 & 5,6 & & & & & & & & \\
\hline 5 & Hypertensive diseases (110-115) & 464 & 4,3 & & & & & & & & \\
\hline 6 & Cerebrovascular diseases (160-169) & 439 & 4,1 & & & & & & & & \\
\hline 7 & Chronic lower respiratory diseases (J40-J47) & 327 & 3,0 & & & & & & & & \\
\hline 8 & Diabetes mellitus (E10-E14) & 320 & 3,0 & & & & & & & & \\
\hline 9 & $\begin{array}{l}\text { Certain disorders involving the immune mechanism } \\
\text { (D80-D89) }\end{array}$ & 232 & 2,2 & & & & & & & & \\
\hline \multirow[t]{4}{*}{10} & $\begin{array}{l}\text { Respiratory and cardiovascular disorders specific } \\
\text { to the perinatal period (P20-P29) }\end{array}$ & 224 & 2,1 & & & & & & & & \\
\hline & Other natural causes & 3845 & 35,7 & & & & & & & & \\
\hline & Non-natural causes & 634 & 5,9 & & & & & & & & \\
\hline & All causes & 10777 & 100,0 & & & & & & & & \\
\hline
\end{tabular}




\section{Appendix N.6: The ten leading underlying natural causes of death by district municipality of death occurrence, Gauteng, 2009}

\begin{tabular}{|c|c|c|c|c|c|c|c|c|c|c|c|}
\hline \multicolumn{2}{|r|}{ City of Johannesburg Metro } & \multirow{2}{*}{$\begin{aligned} \text { No. } \\
3083\end{aligned}$} & \multirow{2}{*}{$\begin{array}{c}\% \\
8,3\end{array}$} & \multicolumn{2}{|r|}{ City of Tshwane Metro } & \multirow{2}{*}{$\begin{aligned} \text { No. } \\
2231\end{aligned}$} & \multirow{2}{*}{$\begin{aligned} \% \\
8,4\end{aligned}$} & \multicolumn{2}{|r|}{ Ekurhuleni Metro } & \multirow{2}{*}{$\begin{aligned} \text { No. } \\
3273\end{aligned}$} & \multirow{2}{*}{$\begin{array}{r}\% \\
10,7\end{array}$} \\
\hline 1 & Tuberculosis (A15-A19) & & & 1 & Tuberculosis (A15-A19) & & & 1 & Tuberculosis (A15-A19) & & \\
\hline 2 & Influenza and pneumonia (J09-J18) & 2334 & 6,3 & 2 & Other forms of heart disease (130-152) & 1939 & 7,3 & 2 & Influenza and pneumonia (J09-J18) & 2837 & 9,3 \\
\hline 3 & Other forms of heart disease (130-152) & 1594 & 4,3 & 3 & Influenza and pneumonia (J09-J18) & 1882 & 7,1 & 3 & Other forms of heart disease (130-152) & 1459 & 4,8 \\
\hline 4 & $\begin{array}{l}\text { Human immunodeficiency virus [HIV] disease } \\
\text { (B20-B24) }\end{array}$ & 1429 & 3,9 & 4 & Cerebrovascular diseases (160-169) & 1270 & 4,8 & 4 & Intestinal infectious diseases (A00-A09) & 1285 & 4,2 \\
\hline 5 & Cerebrovascular diseases (160-169) & 1150 & 3,1 & 5 & Intestinal infectious diseases (A00-A09) & 1162 & 4,4 & 5 & Cerebrovascular diseases (160-169) & 1045 & 3,4 \\
\hline 6 & Diabetes mellitus (E10-E14) & 1080 & 2,9 & 6 & Diabetes mellitus (E10-E14) & 1151 & 4,3 & 6 & Diabetes mellitus (E10-E14) & 810 & 2,6 \\
\hline 7 & Intestinal infectious diseases (A00-A09) & 1058 & 2,9 & 7 & Hypertensive diseases (110-115) & 1041 & 3,9 & 7 & Other viral diseases (B25-B34) & 795 & 2,6 \\
\hline 8 & Ischaemic heart diseases (I20-I25) & 921 & 2,5 & 7 & Ischaemic heart diseases (I20-I25) & 932 & 3,5 & 8 & $\begin{array}{l}\text { Human immunodeficiency virus [HIV] disease } \\
\text { (B20-B24) }\end{array}$ & 696 & 2,3 \\
\hline 9 & Hypertensive diseases (110-115) & 850 & 2,3 & 9 & $\begin{array}{l}\text { Human immunodeficiency virus [HIV] disease } \\
\text { (B20-B24) }\end{array}$ & 776 & 2,9 & 9 & $\begin{array}{l}\text { Inflammatory diseases of the central nervous } \\
\text { system (G00-G09) }\end{array}$ & 624 & 2,0 \\
\hline \multirow[t]{5}{*}{10} & Malignant neoplasm of digestive organs (C15-C26) & 755 & 2,0 & 10 & Malignant neoplasm of digestive organs (C15-C26) & 664 & 2,5 & 10 & $\begin{array}{l}\text { Respiratory and cardiovascular disorders specific } \\
\text { to the perinatal period (P20-P29) }\end{array}$ & 606 & 2,0 \\
\hline & Other natural causes & 19119 & 51,7 & & Other natural causes & 10977 & 41,1 & & Other natural causes & 14398 & 47,1 \\
\hline & Non-natural causes & 3584 & 9,7 & & Non-natural causes & 2669 & 10,0 & & Non-natural causes & 2743 & 9,0 \\
\hline & All causes & 36957 & 100,0 & & All causes & 26694 & 100,0 & & All causes & 30571 & 100,0 \\
\hline & Sedibeng & No. & $\%$ & \multicolumn{2}{|r|}{ West Rand } & No. & $\%$ & & & & \\
\hline 1 & Influenza and pneumonia (J09-J18) & 1484 & 14,0 & 1 & Influenza and pneumonia (J09-J18) & 1035 & 10,5 & & & & \\
\hline 2 & Tuberculosis (A15-A19) & 1011 & 9,5 & 2 & Tuberculosis (A15-A19) & 994 & 10,1 & & & & \\
\hline 3 & Other forms of heart disease (130-152) & 743 & 7,0 & 3 & Intestinal infectious diseases (A00-A09) & 642 & 6,5 & & & & \\
\hline 4 & Intestinal infectious diseases (A00-A09) & 673 & 6,3 & 4 & Other forms of heart disease (130-152) & 417 & 4,2 & & & & \\
\hline 5 & Cerebrovascular diseases (160-169) & 559 & 5,3 & 5 & Cerebrovascular diseases (160-169) & 356 & 3,6 & & & & \\
\hline 6 & Diabetes mellitus (E10-E14) & 412 & 3,9 & 6 & $\begin{array}{l}\text { Certain disorders involving the immune } \\
\text { mechanism (D80-D89) }\end{array}$ & 256 & 2,6 & & & & \\
\hline 7 & Hypertensive diseases (110-115) & 342 & 3,2 & 7 & Diabetes mellitus (E10-E14) & 235 & 2,4 & & & & \\
\hline 8 & Ischaemic heart diseases (I20-I25) & 272 & 2,6 & 8 & $\begin{array}{l}\text { Inflammatory diseases of the central nervous } \\
\text { system (G00-G09) }\end{array}$ & 221 & 2,2 & & & & \\
\hline 9 & $\begin{array}{l}\text { Inflammatory diseases of the central nervous } \\
\text { system (G00-G09) }\end{array}$ & 266 & 2,5 & 9 & Chronic lower respiratory diseases (J40-J47) & 217 & 2,2 & & & & \\
\hline 10 & Chronic lower respiratory diseases (J40-J47) & 230 & 2,2 & 10 & Other viral diseases (B25-B34) & 207 & 2,1 & & & & \\
\hline & Other natural causes & 3747 & 35,3 & & Other natural causes & 4292 & 43,5 & & & & \\
\hline & Non-natural causes & 869 & 8,2 & & Non-natural causes & 991 & 10,0 & & & & \\
\hline & All causes & 10608 & 100,0 & & All causes & 9863 & 100,0 & & & & \\
\hline
\end{tabular}




\section{Appendix N.7: The ten leading underlying natural causes of death by district municipality of death occurrence, Mpumalanga, 2009}

\begin{tabular}{|c|c|c|c|c|c|c|c|c|c|c|c|}
\hline & Ehlanzeni & No. & $\%$ & & Gert Sibande & No. & $\%$ & & Nkangala & No. & $\%$ \\
\hline 1 & Tuberculosis (A15-A19) & 3037 & 16,1 & 1 & Tuberculosis (A15-A19) & 1781 & 12,5 & 1 & Influenza and pneumonia (J09-J18) & 1534 & 12,2 \\
\hline 2 & Intestinal infectious diseases (A00-A09) & 1735 & 9,2 & 2 & Influenza and pneumonia (J09-J18) & 1364 & 9,6 & 2 & Tuberculosis (A15-A19) & 1316 & 10,4 \\
\hline 3 & Influenza and pneumonia (J09-J18) & 1381 & 7,3 & 3 & Intestinal infectious diseases (A00-A09) & 1032 & 7,2 & 3 & Other forms of heart disease (130-152) & 727 & 5,8 \\
\hline 4 & Cerebrovascular diseases (160-169) & 1107 & 5,9 & 4 & $\begin{array}{l}\text { Human immunodeficiency virus [HIV] disease } \\
\text { (B20-B24) }\end{array}$ & 814 & 5,7 & 4 & Intestinal infectious diseases (A00-A09) & 724 & 5,7 \\
\hline 5 & $\begin{array}{l}\text { Human immunodeficiency virus [HIV] disease } \\
\text { (B20-B24) }\end{array}$ & 756 & 4,0 & 5 & Other forms of heart disease (130-152) & 609 & 4,3 & 5 & Hypertensive diseases (110-115) & 589 & 4,7 \\
\hline 6 & Other forms of heart disease (130-152) & 673 & 3,6 & 6 & $\begin{array}{l}\text { Certain disorders involving the immune } \\
\text { mechanism (D80-D89) }\end{array}$ & 562 & 3,9 & 6 & Diabetes mellitus (E10-E14) & 491 & 3,9 \\
\hline 7 & Diabetes mellitus (E10-E14) & 619 & 3,3 & 7 & Cerebrovascular diseases (160-169) & 558 & 3,9 & 7 & Cerebrovascular diseases (160-169) & 485 & 3,8 \\
\hline 8 & $\begin{array}{l}\text { Certain disorders involving the immune mechanism } \\
\text { (D80-D89) }\end{array}$ & 571 & 3,0 & 7 & Diabetes mellitus (E10-E14) & 483 & 3,4 & 8 & Chronic lower respiratory diseases (J40-J47) & 439 & 3,5 \\
\hline 9 & Other acute lower respiratory infections (J20-J22) & 561 & 3,0 & 9 & Hypertensive diseases (110-115) & 337 & 2,4 & 9 & $\begin{array}{l}\text { Certain disorders involving the immune } \\
\text { mechanism (D80-D89) }\end{array}$ & 347 & 2,8 \\
\hline 10 & Other viral diseases (B25-B34) & 483 & 2,6 & 10 & Other acute lower respiratory infections (J20-J22) & 308 & 2,2 & 10 & Other viral diseases (B25-B34) & 267 & 2,1 \\
\hline & Other natural causes & 6384 & 33,9 & & Other natural causes & 5309 & 37,3 & & Other natural causes & 4328 & 34,3 \\
\hline & Non-natural causes & 1523 & 8,1 & & Non-natural causes & 1081 & 7,6 & & Non-natural causes & 1362 & 10,8 \\
\hline & All causes & 18830 & 100,0 & & All causes & 14238 & 100,0 & & All causes & 12609 & 100,0 \\
\hline
\end{tabular}




\section{Appendix N.8: The ten leading underlying natural causes of death by district municipality of death occurrence, Limpopo, 2009}

\begin{tabular}{|c|c|c|c|c|c|c|c|c|c|c|c|}
\hline \multicolumn{2}{|r|}{ Capricorn } & \multirow{2}{*}{$\begin{array}{r}\text { No. } \\
1841\end{array}$} & \multirow{2}{*}{$\begin{array}{r}\% \\
12,2\end{array}$} & & \multirow{2}{*}{$\begin{array}{r}\text { No. } \\
2466\end{array}$} & \multirow{2}{*}{$\begin{array}{r}\% \\
21,4\end{array}$} & \multicolumn{2}{|c|}{ Mopani } & \multirow{2}{*}{$\begin{array}{r}\text { No. } \\
1000\end{array}$} & \multirow{2}{*}{$\begin{array}{r}\% \\
9,0\end{array}$} \\
\hline 1 & Influenza and pneumonia (J09-J18) & & & \multicolumn{2}{|r|}{$\begin{array}{l}\text { Greater Sekhukhune } \\
\text { Influenza and pneumonia (J09-J18) }\end{array}$} & & & 1 & Intestinal infectious diseases (A00-A09) & & \\
\hline 2 & Tuberculosis (A15-A19) & 1377 & 9,1 & 2 & Intestinal infectious diseases (A00-A09) & 1093 & 9,5 & 2 & Influenza and pneumonia (J09-J18) & 967 & 8,7 \\
\hline 3 & Intestinal infectious diseases (A00-A09) & 1318 & 8,8 & 3 & Tuberculosis (A15-A19) & 918 & 8,0 & 3 & Tuberculosis (A15-A19) & 892 & 8,0 \\
\hline 4 & Other forms of heart disease (130-152) & 770 & 5,1 & 4 & Cerebrovascular diseases (160-169) & 814 & 7,1 & 4 & Cerebrovascular diseases (160-169) & 458 & 4,1 \\
\hline 5 & Hypertensive diseases (110-115) & 659 & 4,4 & 5 & Other forms of heart disease (130-152) & 744 & 6,5 & 5 & Other forms of heart disease (130-152) & 430 & 3,9 \\
\hline 6 & Cerebrovascular diseases (160-169) & 612 & 4,1 & 6 & Hypertensive diseases (110-115) & 471 & 4,1 & 6 & Diabetes mellitus (E10-E14) & 374 & 3,4 \\
\hline 7 & Diabetes mellitus (E10-E14) & 591 & 3,9 & 7 & Diabetes mellitus (E10-E14) & 404 & 3,5 & 7 & $\begin{array}{l}\text { Certain disorders involving the immune } \\
\text { mechanism (D80-D89) }\end{array}$ & 239 & 2,1 \\
\hline 8 & $\begin{array}{l}\text { Certain disorders involving the immune mechanism } \\
\text { (D80-D89) }\end{array}$ & 347 & 2,3 & 7 & $\begin{array}{l}\text { Certain disorders involving the immune } \\
\text { mechanism (D80-D89) }\end{array}$ & 329 & 2,9 & 8 & $\begin{array}{l}\text { Inflammatory diseases of the central nervous } \\
\text { system (G00-G09) }\end{array}$ & 224 & 2,0 \\
\hline 9 & Chronic lower respiratory diseases (J40-J47) & 308 & 2,0 & 9 & Chronic lower respiratory diseases (J40-J47) & 274 & 2,4 & 9 & Other viral diseases (B25-B34) & 182 & 1,6 \\
\hline 10 & Other viral diseases (B25-B34) & 225 & 1,5 & 10 & $\begin{array}{l}\text { Diseases of oesophagus, stomach and duodenum } \\
\text { (K20-K31) }\end{array}$ & 162 & 1,4 & 10 & Hypertensive diseases (110-115) & 155 & 1,4 \\
\hline & Other natural causes & 5873 & 39,0 & & Other natural causes & 3068 & 26,7 & & Other natural causes & 5483 & 49,2 \\
\hline & Non-natural causes & 1138 & 7,6 & & Non-natural causes & 757 & 6,6 & & Non-natural causes & 739 & 6,6 \\
\hline & All causes & 15059 & 100,0 & & All causes & 11500 & 100,0 & & All causes & 11143 & 100,0 \\
\hline & Vhembe & No. & $\%$ & & Waterberg & No. & $\%$ & & & & \\
\hline 1 & Tuberculosis (A15-A19) & 958 & 9,6 & 1 & Tuberculosis (A15-A19) & 550 & 10,5 & & & & \\
\hline 2 & Intestinal infectious diseases (A00-A09) & 776 & 7,8 & 2 & Influenza and pneumonia (J09-J18) & 475 & 9,1 & & & & \\
\hline 3 & Influenza and pneumonia (J09-J18) & 674 & 6,8 & 3 & Intestinal infectious diseases (A00-A09) & 334 & 6,4 & & & & \\
\hline 4 & Diabetes mellitus (E10-E14) & 425 & 4,3 & 4 & Other forms of heart disease (130-152) & 192 & 3,7 & & & & \\
\hline 5 & Cerebrovascular diseases (160-169) & 327 & 3,3 & 5 & Cerebrovascular diseases (160-169) & 185 & 3,5 & & & & \\
\hline 6 & Other forms of heart disease (I30-152) & 278 & 2,8 & 6 & $\begin{array}{l}\text { Certain disorders involving the immune } \\
\text { mechanism (D80-D89) }\end{array}$ & 183 & 3,5 & & & & \\
\hline 7 & Diseases of liver (K70-K77) & 177 & 1,8 & 7 & Hypertensive diseases (110-115) & 144 & 2,7 & & & & \\
\hline 8 & Other bacterial diseases (A30-A49) & 140 & 1,4 & 8 & Diabetes mellitus (E10-E14) & 130 & 2,5 & & & & \\
\hline 8 & $\begin{array}{l}\text { Certain disorders involving the immune mechanism } \\
\text { (D80-D89) }\end{array}$ & 140 & 1,4 & 9 & Ischaemic heart diseases (120-I25) & 114 & 2,2 & & & & \\
\hline 10 & Renal failure (N17-N19) & 139 & 1,4 & 10 & Chronic lower respiratory diseases (J40-J47) & 101 & 1,9 & & & & \\
\hline & Other natural causes & 5208 & 52,4 & & Other natural causes & 2302 & 43,9 & & & & \\
\hline & Non-natural causes & 701 & 7,1 & & Non-natural causes & 534 & 10,2 & & & & \\
\hline & All causes & 9943 & 100,0 & & All causes & 5244 & 100,0 & & & & \\
\hline
\end{tabular}




\section{Appendix 0: Population group differences}

In over a quarter $(26,2 \%)$ of all deaths, population group was not specified. Although the importance of population group in mortality is acknowledged, further analysis by population group is restricted to the appendix as the results are not considered useful for planning purposes due to this large number of unspecified cases. Readers are therefore advised to treat the breakdowns of deaths by population group with caution.

Appendix 0.1 provides the breakdown of the ten leading causes of death for 2009 by population group (including cases where population group was reported as 'other', unknown or unspecified). The results show that four of the ten leading causes of death were common for the four population groups, namely other forms of heart disease, cerebrovascular diseases, diabetes mellitus, and hypertensive diseases. These common causes of death had different ranks and different contributions to the overall number of deaths for each population group. For example, other forms of heart diseases were the second leading cause of death among the white population group, third among the Indian/Asian population group, fourth among the Black African and seventh among the coloured population group.

Tuberculosis was the leading underlying natural cause of death for black African and coloured population groups, accounting for $13,9 \%$ and $9,0 \%$, respectively, of all deaths in these groups. The leading cause of death among Indians/Asians was diabetes mellitus while ischaemic heart diseases were the leading cause among the white population group. The three leading and the ninth leading causes of death for the white population group were all diseases of the circulatory system, all contributing $28,2 \%$ of all deaths among the white population group.

On one hand, intestinal infectious diseases, certain disorders involving the immune mechanism and other viral diseases were among the ten leading causes of natural deaths only for the black African population group. On the other hand, ischaemic heart diseases, malignant neoplasms of digestive organs and chronic lower respiratory system diseases were among the ten leading underlying causes of natural deaths for all population groups, except for the black African population group.

Tuberculosis was among the leading underlying natural causes of death for all population groups, except the white population group, ranking first among black Africans and coloureds and tenth among the Indian/Asian population. Malignant neoplasms of respiratory and intrathoracic organs were among the ten leading underlying causes of death only for the white and coloured population groups while renal failure was among the ten leading underlying causes of death only for the white and Indian/Asian population groups.

Nine of the ten leading causes of death for the other/unknown/unspecified population group were similar to those of black Africans, with the first five having the same rank. The number of causes that were similar with the other/unknown/unspecified population group was five for the white population group, and six each for Indians/Asians and the coloured population group, with differing ranks.

The percentages of deaths due to non-natural causes did not differ widely between population groups, ranging from $7,9 \%$ among the white population group to 10,7 among the coloured population group. 


\section{Appendix 0.1: The ten leading underlying natural causes of death by population group, 2009}

\begin{tabular}{|c|c|c|c|c|c|c|c|c|c|c|c|c|c|c|c|}
\hline \multirow{2}{*}{$\begin{array}{l}\text { Causes of death (based on the } \\
10^{\text {th }} \text { Revision, International } \\
\text { Classification of Diseases, } \\
1992 \text { ) }\end{array}$} & \multicolumn{3}{|c|}{ Black African } & \multicolumn{3}{|c|}{ White } & \multicolumn{3}{|c|}{ Indian/Asian } & \multicolumn{3}{|c|}{ Coloured } & \multicolumn{3}{|c|}{ Other/Unknown/unspecified } \\
\hline & Rank & Number & $\%$ & Rank & Number & $\%$ & Rank & Number & $\%$ & Rank & Number & $\%$ & Rank & Number & $\%$ \\
\hline Tuberculosis $(\mathrm{A} 15-\mathrm{A} 19)^{*}$ & 1 & 49094 & 13,9 & $\ldots$ & $\ldots$ & $\ldots$ & 10 & 147 & 2,0 & 1 & 2257 & 9,0 & 1 & 17243 & 11,5 \\
\hline $\begin{array}{l}\text { Influenza and pneumonia (J09- } \\
\text { J18) }\end{array}$ & 2 & 31427 & 8,9 & 6 & 1659 & 4,6 & 9 & 173 & 2,3 & $\cdots$ & $\cdots$ & $\cdots$ & 2 & 8917 & 5,9 \\
\hline $\begin{array}{l}\text { Intestinal infectious diseases } \\
\text { (A00-A09) }\end{array}$ & 3 & 22799 & 6,4 & $\cdots$ & $\cdots$ & $\cdots$ & $\cdots$ & $\cdots$ & $\cdots$ & $\cdots$ & $\cdots$ & $\cdots$ & 3 & 7162 & 4,8 \\
\hline $\begin{array}{l}\text { Other forms of heart disease (I30- } \\
\text { I52) }\end{array}$ & 4 & 16280 & 4,6 & 2 & 2622 & 7,2 & 3 & 592 & 7,9 & 7 & 965 & 3,8 & 4 & 6003 & 4,0 \\
\hline $\begin{array}{l}\text { Cerebrovascular diseases (160- } \\
\text { I69) }\end{array}$ & 5 & 15603 & 4,4 & 3 & 2140 & 5,9 & 4 & 347 & 4,6 & 4 & 1351 & 5,4 & 5 & 5394 & 3,6 \\
\hline HIV disease (B20-B24) & 6 & 12683 & 3,6 & $\ldots$ & $\ldots$ & $\ldots$ & $\ldots$ & $\ldots$ & $\cdots$ & 10 & 826 & 3,3 & 7 & 3986 & 2,7 \\
\hline Diabetes mellitus (E10-E14) & 7 & 11429 & 3,2 & 7 & 1520 & 4,2 & 1 & 1047 & 14,0 & 2 & 1655 & 6,6 & 6 & 4872 & 3,2 \\
\hline Hypertensive diseases (I10-I15) & 8 & 10048 & 2,8 & 9 & 910 & 2,5 & 7 & 239 & 3,2 & 6 & 966 & 3,8 & $\ldots$ & $\ldots$ & $\ldots$ \\
\hline $\begin{array}{l}\text { Certain disorders involving the } \\
\text { immune mechanism (D80-D89) }\end{array}$ & 9 & 9245 & 2,6 & $\cdots$ & $\ldots$ & $\cdots$ & $\cdots$ & $\cdots$ & $\cdots$ & $\cdots$ & $\cdots$ & $\cdots$ & 8 & 3498 & 2,3 \\
\hline Other viral diseases (B25-B34) & 10 & 7988 & 2,3 & $\ldots$ & $\ldots$ & $\ldots$ & $\ldots$ & $\ldots$ & $\ldots$ & $\ldots$ & $\ldots$ & $\ldots$ & 9 & 3377 & 2,2 \\
\hline Ischaemic heart diseases (I20-I25) & $\cdots$ & $\ldots$ & $\ldots$ & 1 & 4538 & 12,5 & 2 & 1026 & 13,7 & 5 & 1290 & 5,1 & $\cdots$ & $\ldots$ & .. \\
\hline $\begin{array}{l}\text { Malignant neoplasm of digestive } \\
\text { organs (C15-C26) }\end{array}$ & $\cdots$ & $\ldots$ & $\ldots$ & 4 & 1966 & 5,4 & 5 & 264 & 3,5 & 9 & 858 & 3,4 & $\cdots$ & .. & $\ldots$ \\
\hline $\begin{array}{l}\text { Chronic lower respiratory diseases } \\
\text { (J40-J47) }\end{array}$ & $\cdots$ & $\ldots$ & $\ldots$ & 5 & 1852 & 5,1 & 6 & 245 & 3,3 & 3 & 1478 & 5,9 & 10 & 3342 & 2,2 \\
\hline $\begin{array}{l}\text { Malignant neoplasm of respiratory } \\
\text { and intrathoracic organs (C30-39) }\end{array}$ & $\cdots$ & $\cdots$ & $\ldots$ & 8 & 1304 & 3,6 & $\cdots$ & $\cdots$ & $\cdots$ & 8 & 960 & 3,8 & $\cdots$ & $\cdots$ & .. \\
\hline Renal failure (N17-N19) & $\ldots$ & $\ldots$ & $\ldots$ & 10 & 817 & 2,3 & 8 & 199 & 2,7 & $\ldots$ & $\ldots$ & $\ldots$ & $\ldots$ & $\ldots$ & ... \\
\hline Other natural causes & & 134714 & 38,1 & & 14066 & 38,8 & & 2459 & 32,9 & & 9875 & 39,2 & & 75500 & 50,3 \\
\hline Non-natural causes & & 32297 & 9,1 & & 2866 & 7,9 & & 729 & 9,8 & & 2697 & 10,7 & & 10867 & 7,2 \\
\hline All causes & & 353607 & 100,0 & & 36260 & 100,0 & & 7467 & 100,0 & & 25178 & 100,0 & & 150161 & 100,0 \\
\hline
\end{tabular}

${ }^{*}$ Including deaths due to $M D R-T B$ and $X D R-T B$

Category not in top ten 